\title{
XIKANG: HAN CHINESE IN SICHUAN'S WESTERN FRONTIER, 1905-1949.
}

\author{
by \\ Joe Lawson
}

A thesis

submitted to the Victoria University of Wellington in fulfilment of the requirements for the degree of Doctor of Philosophy in Chinese

Victoria University of Wellington 2011 


\begin{abstract}
This thesis is about Han Chinese engagement with the ethnically diverse highlands west and south-west of the Sichuan basin in the first half of the twentieth century. This territory, which includes much of the Tibetan Kham region as well as the mostly $\mathrm{Yi}$ - and Han-settled Liangshan, constituted Xikang province between 1939 and 1955 . The thesis begins with an analysis of the settlement policy of the late Qing governor Zhao Erfeng, as well as the key sources of influence on it. Han authority suffered setbacks in the late 1910s, but recovered from the mid-1920s under the leadership of General Liu Wenhui, and the thesis highlights areas of similarity and difference between the Zhao and Liu periods. Although contemporaries and later historians have often dismissed the attempts to build Han Chinesedominated local governments in the highlands as failures, this endeavour was relatively successful in a limited number of places. Such success, however, did not entail the incorporation of territory into an undifferentiated Chinese whole. Throughout the highlands, pre-twentieth century local institutions, such as the wula corvée labour tax in Kham, continued to exercise a powerful influence on the development and nature of local and regional government. The thesis also considers the long-term life (and death) of ideas regarding social transformation as developed by leaders and historians of the highlands.
\end{abstract}


Xikang: Han Chinese in Sichuan's Western Frontier, 1905-1949.

$\underline{\text { Table of Contents }}$

Acknowledgements........................................ i

Maps................................................................... ii

Abbreviations used in this thesis $\ldots \ldots \ldots \ldots \ldots \ldots \ldots \ldots \ldots \ldots \ldots \ldots \ldots \ldots$

Measures and currencies .......................................... vi

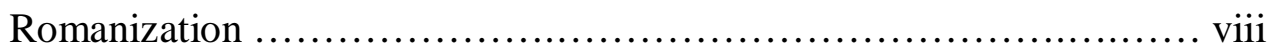

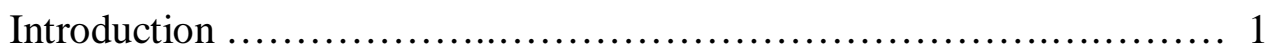

Chapter One: The Rise and Fall and Rise of Chinese Authority in the Sichuan frontier, $1905-1949$..................................... 23

Chapter Two: Development Visions and Policy, 1905-1911 _........... 5

Chapter Three: Continuity and Change in the Republican Period ......... 88

Chapter Four: Corvée Labour and the Development of the Regional and Local Chinese Authority in Kham ................................. 123

Chapter Five: Conflict, Security and Ethnicity in Liangshan........... 163

Chapter Six: Han Migrants in the Frontier, 1905-1949................ 194

Chapter Seven: Visions of Transformation: Culture and Politics on the

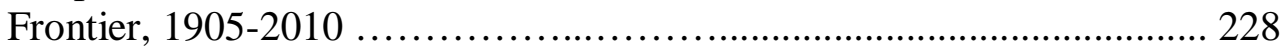

Conclusion ....................................................... 265

Glossary of names for places and ethnic groups .................... 280

Bibliography ............................................... 284 


\section{Acknowledgements}

First and foremost, I am indebted to Brian Moloughney, who introduced me to Chinese history, and has guided my work on this project as a mentor and a friend. I was lucky to have the help of someone so astute, meticulous, unassuming and generous with his time.

I am very grateful to the following people, who have also made very significant contributions toward this project, either by reading and commenting on sections of it, or by assisting me in the hunt for sources or with coming to grips with Qing official-ese: James Leibold, James Belich, Duncan Campbell, Richard Phillips, 王川, 张学君, 柯伟明 and 邹立波.

In addition, I have benefited greatly from conversations with and encouragement from people who are too numerous to name in their entirety. I am particularly grateful to Lewis Mayo, Pauline Keating, James Beattie, Alexander Maxwell, Justin Tighe, Geremie Barmé, 曹润青, Limin Bai and Lize.

Institutionally, funding from Victoria University of Wellington and the New Zealand Asian Studies Society enabled me to undertake this research.

Finally, I wish to thank my students, teachers, and friends in China, who made my years in their country so great. And my parents, who always supported me with everything I wanted to do. 


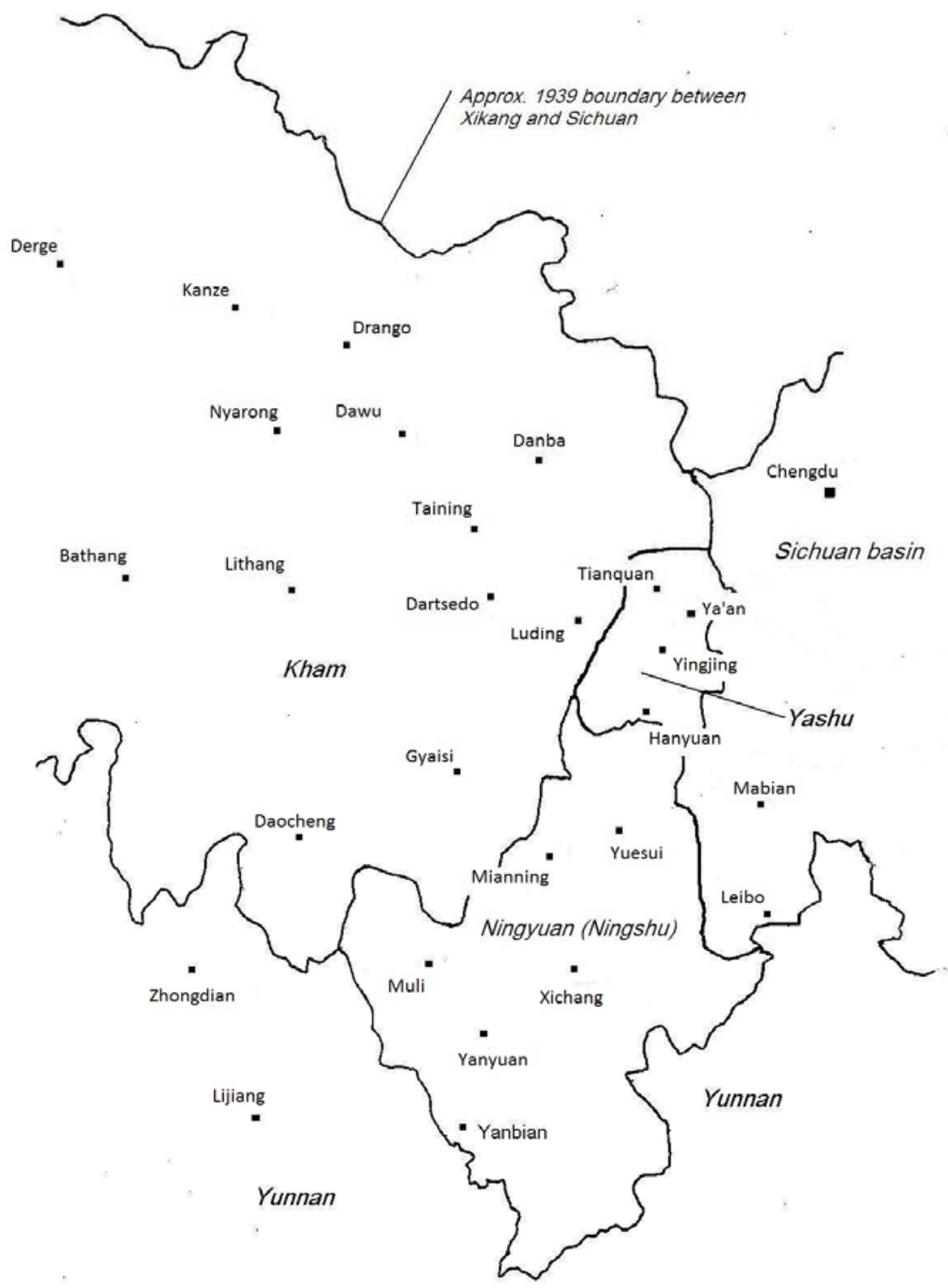

Map 1: Sketch map with main places referred to in this thesis. 


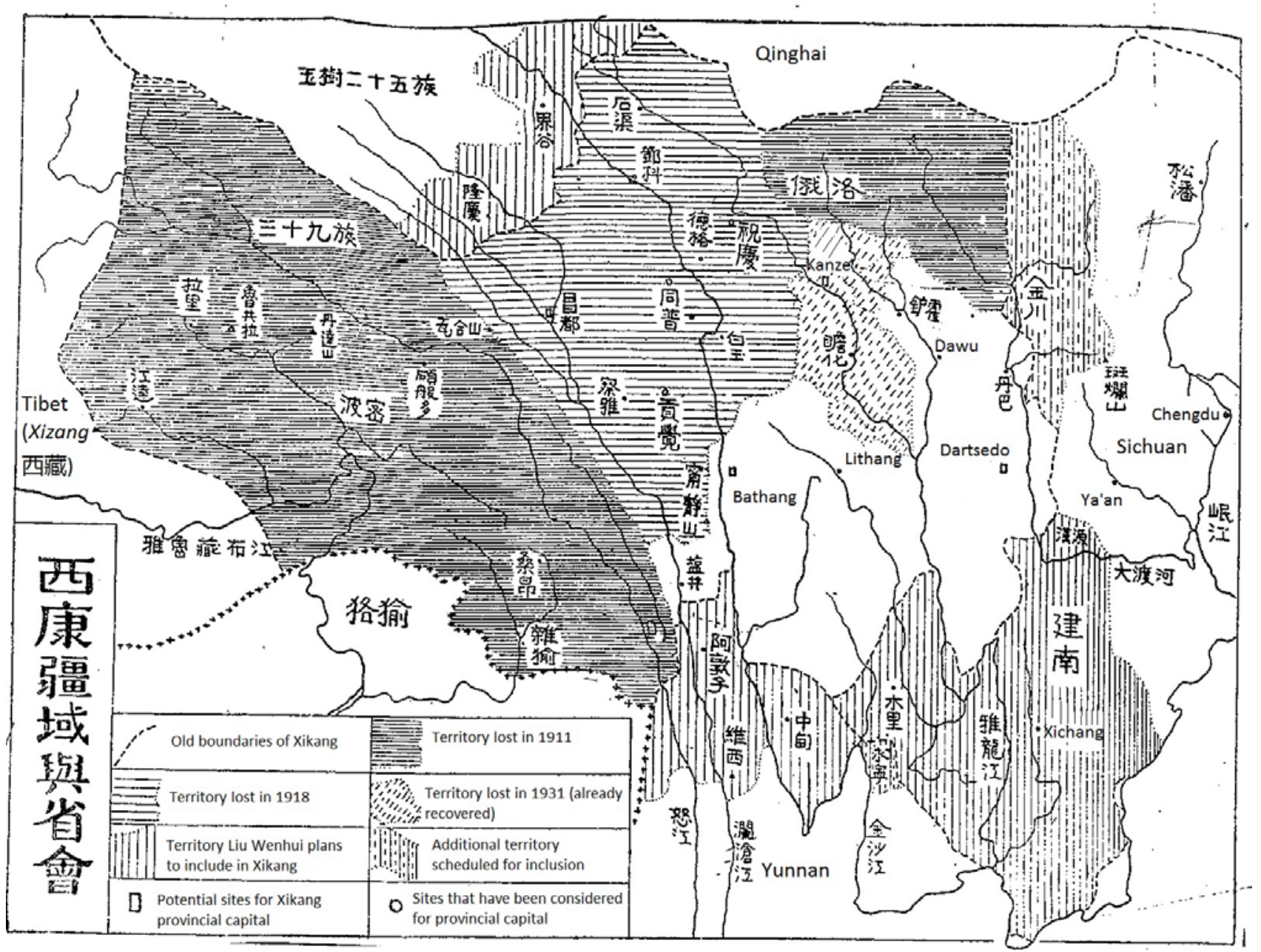

Map 2: Ren Naiqiang's sketch map of Xikang, showing territory controlled by Liu Wenhui's regional government in 1933, as well as "lost" territory and territory Liu planned to include. (With labels translated by Lawson).

Source: Ren Naiqiang 任乃強, Xikang tujing: jingyu pian 西康 圖經: 境域篇, (Shanghai: Shanghai shudian, 1933), 82-83. 


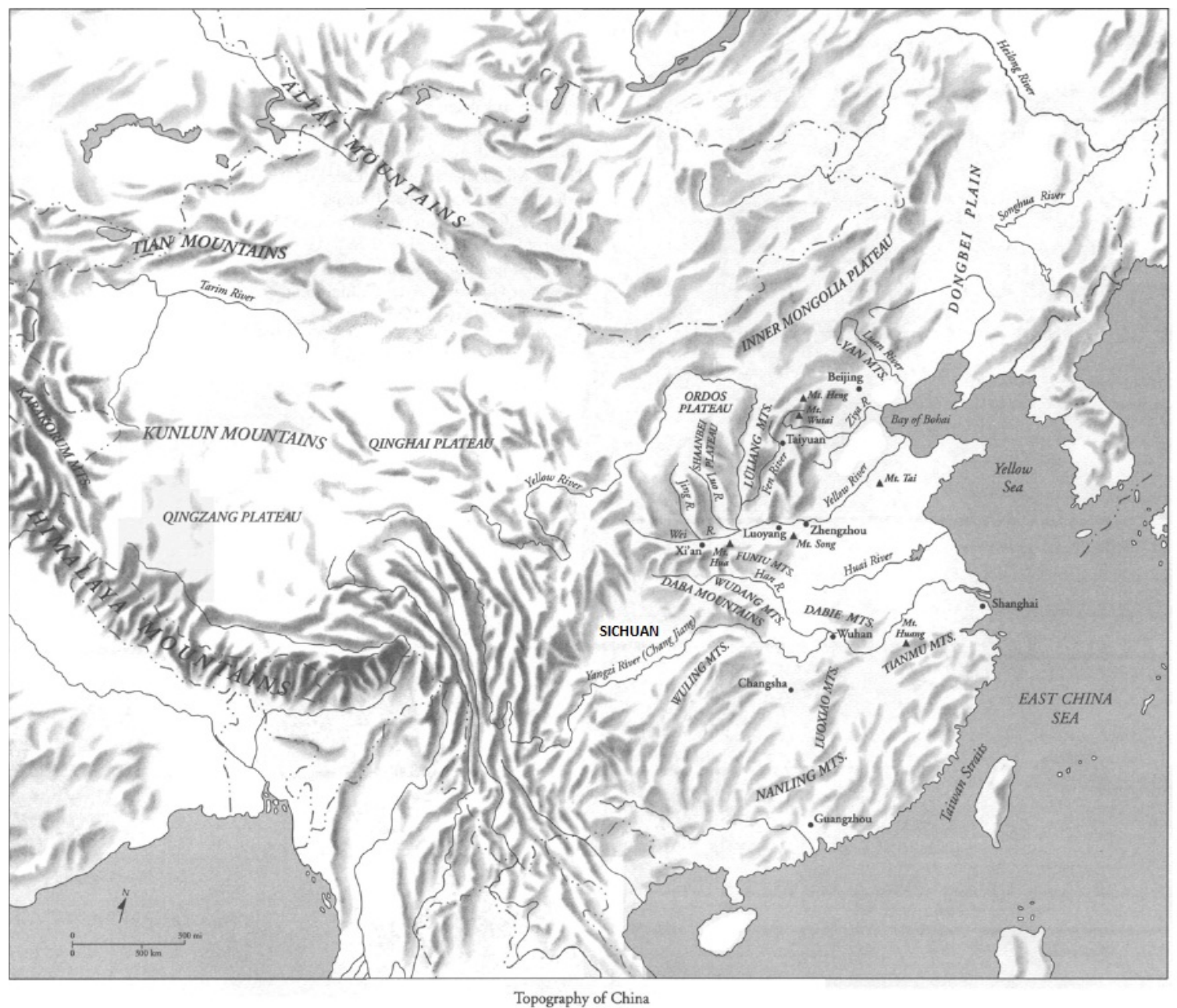

Map 3: Topographical Map of

China

Source: Michael Loewe and Edward L.

Shaughnessy eds., The Cambridge History

of Ancient China, volume 1, (Cambridge,

Cambridge University Press, 1999).

Topography of China 


\section{Abbreviations used in this thesis}

AJH: An juan hao 案卷号 (folder reference number in Sichuan Provincial Archives catalogue system).

CKSB: Guomin canzheng hui. Chuan kang jianshe shicha tuan 國民參政會. 川康建設視察團, ed. Guomin canzhenghui Chuan-Kang jianshe shichatuan baogao shu 國民參政會川康建設視察團報告書. Taibei: Wenhai chubanshe youxian gongsi, 1971 [1939].

JKDZ: Sichuan sheng dang'an guan 四川省档案馆, and Sichuan minzu yanjiu suo 四川民族研究所, eds. Jindai Kang qu dang'an ziliao xuanbian 近代康区档案资料选编. Chengdu: Sichuan daxue chubanshe, 1990.

SCDAG: Sichuan sheng dang’an guan 四川省档案馆 (Sichuan Provincial Archives).

SYSD: Zhongguo shaoshu minzu shehui lishi diaocha ziliao congkan' xiuding bianji weiyuanhui 《中国少数民族社会历史调查资料丛 刊》修订编辑委员会, ed. Sichuan sheng Liangshan Yizu shehui lishi diaocha (zonghe baogao) 四川省凉山彝族社会历史调查（综合报 告). Beijing: Minzu chubanshe, 2009.

QCBD: Sichuan minzu yanjiu suo 四川民族研究所, ed. Qing mo Chuan Dian bianwu dang'an shi liao 清末川滇边务档案史料. 3 vols. Beijing: Zhonghua shuju, 1989.

QZH: Quan zong hao 全宗号: (organization reference number in Sichuan Provincial Archives catalogue system).

ZYDZ: Chongqing Zhongguo yinhang diaocha zuzhi 重慶中國銀行調查組 織 (Chongqing Bank of China Research Group) 


\section{Measures and Currencies}

Money

At least five different units are used in the sources for this thesis.

-Copper cash, (wen 文): The small unit of currency in imperial China.

-Tael, (liang 兩): A weight of silver; a unit of account rather than a currency. The exchange rate between copper cash and taels of silver varied significantly over time and space. 1,000 copper cash per tael is a hypothetical average.

-Dayang yuan (大洋元): Often translated as “silver dollar”, but more literally "foreign coins". These coins in circulation in many parts of China. In Sichuan the normal silver content was .72 taels, so one dayang yuan was worth 2.25 Tibetan yuan. ${ }^{1}$

-Tibetan yuan, (Zang yang yuan 藏洋元): A currency produced by the late Qing government in an attempt to prevent the circulation of Indian rupees in Tibet, circulation appears to have been confined to Kham. ${ }^{2}$ The Tibetan yuan normally had a silver content of .32 taels. So one Tibetan yuan was worth .45 dayang yuan.

-Fabi 法幣: Literally "legal tender", this was the currency issued by the Guomindang. According to the China Agricultural Bank, Han local authorities in Xikang tended to use Tibetan yuan rather than fabi. ${ }^{3}$ In 1935 , one dayang yuan was worth .8 fabi, but the fabi underwent hyperinflation after 1939.

\footnotetext{
${ }^{1}$ Yang Jianwu 杨健吾, "Minguo shiqi kangqu de jinrong caizheng 民国时期康区的金融 财政," Xizang yanjiu 西藏研究 no. 3 (2006), 103.

${ }^{2}$ Ibid.

${ }^{3}$ Zhong Mu 钟穆, "Minguo shiqi de Zangyang zhuzao 民国时期的藏洋铸造," In Ganzi Zhou wenshi ziliao, no. 14 甘孜州文史资料, 第十四辑, ed., Zhongguo renmin zhengzhi xieshang huiyi Ganzi Zangzu zizhizhou weiyuanhui 中国人民政治协商会议甘孜藏族自 治州委员会, (Kangding: Kangding xian yinshua chang, 1996), 83.
} 
$\underline{\text { Volume measures }}$

Grain volumes are measured in shi 石, which contain $10 \mathrm{dou}$ 斗. In imperial and republican China, the size of these units was not standard throughout the country. An eastern Chinese shi of grain weighed approximately $75 \mathrm{~kg}$, while in Sichuan a shi was usually double this size. Zhao Erfeng's Kham administration and those of the Republican period until 1939 used the larger Sichuanese shi, which they called a guan 官 (“official”) shi. Several documents explicitly state that a guan shi of barley weighed around 300 jin 斤 (roughly $150 \mathrm{~kg}$ ) ${ }^{4}$. In 1939, the Xikang administration began using the Guomindang “market” (shi 市) shi, which was based on the eastern Chinese shi, and was thus half the size of the guan shi. ${ }^{5}$

\section{Distance}

The distance measure used in this thesis is a li 里, about half a kilometer.

\section{$\underline{\text { Weight }}$}

The measure of weight used in the sources quoted by this thesis is a jin 斤. The weight of a jin was usually around 600 grams, though like the shi, it varied in late imperial China. Under Guomindang rule weights were metricized, and the weight of a jin was fixed at 500 grams.

\footnotetext{
${ }^{4}$ Zhao Erfeng 赵尔丰, and Wu Fengpei 吴丰培, Zhao Erfeng Chuan bian zou du 赵尔丰川 边奏牍, (Chengdu: Sichuan minzu chubanshe, 1984), 72.

${ }^{5}$ Sichuan sheng dang'an guan 四川省档案馆, and Sichuan minzu yanjiu suo 四川民族研 究所, eds. Jindai Kang qu dang'an ziliao xuanbian 近代康区档案资料选编, (Chengdu: Sichuan daxue chubanshe, 1990), 84.
} 


\section{Romanization and names used in this thesis.}

Chinese names are romanized using the pinyin system. The only standard system for romanizing Tibetan names is the Wylie system, which reproduces the spelling of written Tibetan, with the result that it offers nonspecialists little guide to how a name should be pronounced. For this reason, most scholars who write for a non-Tibetological readership do not use it. I have endeavoured to use the names and orthographies that are most commonly used in scholarly literature written for non-Tibet specialists.

A full glossary of names for places and ethnic groups, including alternative versions and spellings is included at the end of this thesis. A few basic conventions I have adopted are as follows.

The indigenous people of Liangshan are called $\mathrm{Yi}$, which is an exogenous term that is somewhat broader in scope that any endogenous term; but it has become common in English language scholarship.

The administrative region now called Liangshan Yi Autonomous Prefecture (Liangshan Yizu zizhizhou 凉山彝族自治州) was preceded by an administrative territory called Ningshu (甯屬 “Ning territory”) in the Republican period, and Ningyuan Prefecture (寧遠府) in the Qing. Because the boundaries of the three units were somewhat different, I use the periodappropriate term.

“Liangshan 涼山” (“The Cool Mountains”), in this thesis refers to the geographic region of these mountains, not an administrative region.

“Tibetan” includes the native people of Kham, even though they were sometimes thought of as ethnically distinct from the people of central Tibet. This follows current terminology, in Chinese, Tibetan and foreign scholarship.

"Kangding” refers to "Kangding county", while the main township in this county is referred to as Dartsedo (which is now usually also called “Kangding” in Chinese). 


\section{Introduction}

To the west and southwest of the Sichuan basin, one of the cores of Chinese civilization, are highlands that are ethnically and ecologically radically different from the basin. At the broadest level, they can be subdivided into the predominantly Tibetan Kham region and the territory now encompassed by the Liangshan Yi Autonomous Prefecture 凉山彝族自治州, which was known in the Qing dynasty as Ningyuan Prefecture 寧遠府, and Ningshu 甯 屬 in the Republican period. The latter is home to diffuse groups of indigenous people now mostly called $\mathrm{Yi}$ 彝, as well as a significant Han population around Xichang 西昌. For almost all of the Qing period, the nonHan regions in the highlands were not governed by the bureaucratic structure that administered the Han Chinese parts of the empire, a system called junxian 郡縣 in Chinese. They were instead a patchwork of chieftainships, micro-states and, in Kham, monastic estates. These were theoretically subject to the sovereignty of the emperor, but in practice mostly left to their own devices. The Chinese called the secular leaders of such places tusi 土司, or “native officials”.

Despite the considerable diversity of the highlands, Qing and Republican era Chinese leaders and writers often conceptualized it as a single space: the Sichuan frontier (Chuanbian 川邊). ${ }^{1}$ Qing administrative geography united the whole frontier highland region within the Jianchang Circuit 建昌道. This was comprised of the prefectures of Yazhou 雅州 (the nominal boundaries of which included the Kham chieftaincies), Ningyuan, Jiading 嘉定 (present day Leshan 乐山, including non-Han territory Chinese called Ebian 峨邊), and Qiongzhou I 丼 (a Han-populated region west of

\footnotetext{
${ }^{1}$ In the early and mid Qing period "Chuanbian" had another, overlapping but slightly different meaning: the half of Tibet that was to be governed by Sichuan, i.e. 'the Sichuan parts', as opposed to Zangbian 藏邊 ‘the Tsang parts' governed by the Tibetan government in Lhasa. See for example Wu Guangyao 吳光耀, "Xizang gailiu ben wei ji 西藏改流本未紀," in Kangqu Zangzu shehui zhenxi ziliao jiyao (shang) 康区藏族社会 珍稀资料辑要（上）, eds. Zhao Xinyu 赵心愚, Qin Heping 秦和平, and Wang Chuan 王川 (Chengdu: Bashu shushe, 2006), 52-54. In the late Qing and Republican periods the "Sichuan frontier" sense of the term was more common.
} 
Chengdu). The Qing inclusion of the Kham chieftaincies in Yazhou Prefecture did not mean that Yazhou governors had real authority over Kham, but it made Yazhou the base for imperial engagement with that territory.

In the 1900s, the Qing government undertook a campaign in large areas of the Sichuan frontier to replace tusi-rule with junxian administration, an undertaking they called gaitu-guiliu 改土歸流. They sought to expand cultivation of "wasteland", increase Han Chinese settlement, develop mining and other industries, and enact a broad reformation of indigenous culture. Yin Kechang 尹克昌, a member of the Qing Grand Secretariat proposed that the Jianchang Circuit be combined with large areas of Yunnan Province 雲南, including Lijiang 麗江, to create a “Jianchang Province” 建 昌省. ${ }^{2}$ Yin’s plan was not implemented during his lifetime, but the construction of a new province in the region remained high on developmental agendas. In 1906, the court promoted the Jianchang Circuit Intendant, Zhao Erfeng 趙爾豐 (1845-1911) to the newly created position of Warden of the Sichuan and Yunnan Marches (Chuan Dian bianwu dachen 川滇邊務大臣). ${ }^{3}$ Zhao proceeded to increase the intensity and scope of the highlands development programs, particularly in Kham. He also formulated a plan for a new province that included areas of Yunnan. ${ }^{4}$ Months before the 1911 Revolution, Zhao was appointed Governor of Sichuan. His deputy Fu Songmu 傅嵩炑 (1869-1929) took over as Warden of the Marches, and

\footnotetext{
${ }^{2}$ Li Xizhu 李细珠, "Shilun Qing mo xin zheng shiqi zheng qu gaige de ji ge wenti 试论清 末新政时期政区改革的几个问题," Jindai shi yanjiu 近代史研究, no. 2 (2003): 119.

${ }^{3}$ This office is also — and perhaps more often — translated as 'Border Commissioner for Sichuan and Yunnan’. I prefer John Jordan’s ‘Warden of the Marches’ because it preserves a difference in tone from the normal translations of Republican and Socialist period offices in which 'Commissioner' is used for weiyuan 委員.

Birth and death dates are included where they are known.

${ }^{4}$ Wu Guangyao, "Xizang gailiu ben wei ji," 56.
} 
proposed that the planned province be called Xikang 西康 (Kham-in-theWest). ${ }^{5}$

During the 1910s and 20s the term "Xikang" often referred only to Kham, though in Chinese engagement with the Sichuan highlands there was still a strong connection between Kham and Ningshu. Both regions were within the nominal authority of the Sichuan Frontier Garrison Commander (Chuanbian zhenshou shi 川邊鎮守使), and the forces attached to the office operated in both. ${ }^{6}$ In 1916, for example, the commander of Xichang's garrison led a force to Daocheng 稻城 in Kham to re-open a gold mine. ${ }^{7}$ The idea that all the mountainous lands in Sichuan that were west and southwest of the Sichuan basin belonged together in a separate province retained a powerful grip on the imagination of frontier governors. A 1936 report underlined that "there are strong connections [between Kham and Ningshu] in geography and personnel (renshi 人事).” From the late 1920s, positions of authority in civilian and military Han institutions across the highlands were dominated by the network headed by the militarist Liu Wenhui 劉文輝 (1894-1976). Liu’s nephew Liu Yuanzhang 劉元璋, for example, was the Settlement Commander (Tunsiling 屯司令) of Ningshu and the counties of Leibo 雷波, Mabian 馬邊, Pingshan 屏山 and Ebian 峨 邊 east of Ningshu. ${ }^{9}$ There were also personal connections between this

5 "Western Kham" would be a misleading translation, because there was no "Eastern Kham," and nor did anybody think there was. The "Xi" in "Xikang" was needed to make a disyllabic name for consistency with other Chinese place names.

${ }^{6}$ The precise area under the authority of this office is somewhat unclear. The 1941 Xichang Gazetteer makes it clear that the Sichuan Frontier Garrison Commander had authority over a large number of the troops in Xichang in 1920. Zheng Shaocheng 鄭少成 and Yang Zhaoji 楊肇基, Xichang xian zhi 西昌縣志 [1941], reprinted in Zhongguo Xizang ji Gan Qing Chuan Dian Zang qu fang zhi huibian 中國西藏及甘青川滇藏區方志匯編, Vol 40, ed. Zhang Yuxin 张羽新 (Beijing: Xueyuan chubanshe, 2003), 420.

${ }^{7}$ Ren Xinjian 任新建, "Jindai Sichuan Zang qu de huangjin kaifa 近代四川藏区的黄金开 发," in Sichuan Zangxue lunwen ji 四川藏学论文集, edited by Luo Runcang 罗润苍 and Ren Xinjian, (Beijing: Zhongguo Zangxue chubanshe, 1993), 47.

${ }^{8}$ Anonymous (佚名), "Zhili Kangqu yijian shu 治理康区意见书," in Kangqu Zangzu shehui zhenxi ziliao jiyao, ed. Zhao Xinyu, Qin heping, and Wang Chuan, (Chengdu: Bashu shu she, 2006), 404.

${ }^{9}$ Zhang Yongjiu 张永久, Liu Xiang jiazu: Minguo Sichuan di yi jia 刘湘家族: 民国四川 第一家 (Chongqing: Chongqing chubanshe, 2008), 19. 
network and region's indigenous leaders: the daughter of Liu Wenhui's secretary became the second wife of a tusi in Yanyuan. ${ }^{10}$

Still under the control of Liu and his supporters, the western Sichuanese highlands finally became Xikang Province in 1939. The establishment of the province had been held up by the chairman of Sichuan, Liu Xiang 劉湘 (1888-1938), who was Wenhui’s first cousin once removed and adversary in an intra-Sichuan civil war in 1932-33. The elder Liu had been unwilling to formalize Wenhui's control of Yazhou (typically called “Yashu 雅屬” in the Republic) and Ningshu. Liu Xiang's death in 1938 cleared the way for the establishment of a Xikang Province comprised of all three territories at the start of the following year. ${ }^{11}$ The Qing idea of also including some Yunnanese territory in the highland province was abandoned, however, presumably due to interprovincial conflict. Han institutions in Chuanbian were always dominated by Sichuanese; Xikang was, in some respects, a Sichuanese colonial project. $^{12}$

The administrative connections between Ningshu and Kham were reflected in strong connections in the production of knowledge about them. The 1930s journal Sichuan Frontier Quarterly (Chuanbian jikan 川邊季刊) focused on the whole frontier region. Some researchers concentrated on Kham or Ningshu, but many were engaged with both. Zheng Shaocheng 鄭 少成, for example, was one of the principle compilers of the 1941 Xichang Gazetteer (Xichang xianzhi 西昌縣志) and also participated in research on Kham. ${ }^{13}$ Even journals and monographs with titles that indicated an

\footnotetext{
${ }^{10}$ Zhongguo kexueyuan minzu yanjiu suo 中国科学院民族研究所 and Sichuan shaoshu minzu shehui lishi diaocha zu 四川少数民族社会历史调查组, eds., Liangshan Xichang Yizu diqu tusi lishi ji tusi tongzhi qu shehui gaikuang (ziliao huiji) 凉山西昌彝族地区土 司历史及土司统治区社会概况（资料汇辑）(1963), 37.

${ }^{11}$ Liu Jun 刘君, "Jian lun Xikang sheng 简论西康省," in Minguo dang'an yu minguo shi xueshu taolunhui lunwen ji 民国档案与民国史学术讨论会论文集, ed. Zhang Xianwen 张宪文, Chen Xingtang 陈兴唐, and Zheng Huixin 郑会欣 (Beijing: Dang'an chubanshe 1988), 324.

${ }^{12}$ Wang Xiuyu, "China's Last Imperial Frontier: Statecraft and Locality in Qing Kham Tibet, 1890-1911" (PhD, Carnegie Mellon University, 2006), 354-56.

${ }^{13}$ For example, he was a member of the expedition that produced this report: Liu Hengru 刘衡如 et al., "Shicha Dao Lu De Bai Zhan Ya Jiang qi xian baogaoshu 视察道炉甘德白 瞻雅江七县报告书," Xin Xikang 新西康 1, no. 2-3 (1938), reprinted in Kangqu Zangzu
} 
exclusive focus on Kham and Tibet included many articles on Ningshu, as did Kham and Tibet Studies Monthly (Kang Zang yanjiu yuekan 康藏研究 月刊) and Kham Guide Monthly (Kang dao yuekan 康導月刊). ${ }^{14}$

The British missionary Samuel Pollard, who was in Ningyuan during the last years of the Qing and the first of the Republic, noted the utopian tone of many discussions of the highlands and their development.

Over and over again I have heard the Chinese talk of an Eldorado existing in Nosuland [Yi territory]. They call this mythical place Wan Tan Ping - the ten thousand piculs plain [...] They also have a saying:

'If you only open up Wan Tan Ping

The whole word will no more see hungry men., ${ }^{15}$

The frontier territory was often described as a “virgin land” (chunü di 處 女地); an untapped source of riches and a solution to Sichuan’s, or even all China's, problems.

Officials and observers were generally disappointed with the results of the frontier development endeavour, and most foreign historians have underscored its failures. ${ }^{16}$ There was a significant increase in the Han population of certain parts of the eastern fringe of the highlands; around Kangding 康定, Luding 瀘定, Yuesui 越崔 and Hanyuan 漢源; and there were other pockets of increase further west. But many goals were not achieved. Han authority was tenuous or non-existent in many places. A

shehui lishi diaocha ziliao jiyao, eds. Zhao Xinyu and Qin Heping, (Chengdu: Sichuan minzu chubanshe, 2004).

${ }^{14}$ Articles about Ningshu in Kham and Tibet Research Monthly include: Ren Naiqiang 任 乃强, "Lun Ningyuan qu zhi jing jian buzhou 論寧遠區之經建步驟," Kang Zang yanjiu yuekan 康藏研究月刊 1, no. 3 (1946): 2-9; Ling Guangdian 嶺光電, "Wo dui Leibo Yi ren de guangan 我對雷波夷人的觀感," Kang Zang yanjiu yuekan 康藏研究月刊, no. 11 (1946); 28-32.

${ }^{15}$ Samuel Pollard, In Unknown China: a record of the observations, adventures and experiences of a pioneer missionary during a prolonged sojourn amongst the wild and unknown Nosu tribe of western China, (London: Seeley, Service and Co., 1921), 135-36.

${ }^{16}$ For example, Elliot Sperling, "The Chinese Venture in K'am, 1904-1911, and the Role of Chao Erh-feng," The Tibet Journal 1, no. 2 (1976): 32; Hsiao-ting Lin, Tibet and Nationalist China's Frontier: Intrigues and Ethnopolitics, 1928-49 (Vancouver: University of British Columbia Press 2006), 68. 
1938 observer lamented that, throughout large tracts of the highlands, local indigenous headmen had simply become the new tusi, replacing the old tusi who had been deposed by the late Qing campaigns. ${ }^{17}$ The Xikang regional administration was always reliant on outside subsidies, as well as, from the mid-1930s, the export of opium. In 1955, the idea of a separate province in the highlands was abandoned entirely. Xikang's territory was divided up between Sichuan and the Tibet Autonomous Region, along roughly the same border as had separated Sichuan and Lhasa-controlled Tibet during the Qing.

In contrast to foreign and Republican era accounts that emphasize failure, Chinese historians working in the post-Mao period have tended to see Xikang as an unstable but nevertheless important step toward the development of the highlands and their integration within the Chinese nation. ${ }^{18}$ This interpretation is clearly geared toward producing history in a nationalist key, in which events are significant primarily for their contribution to the progress of the Chinese nation-state. Nevertheless, this historical narrative offers a useful reminder that the Chinese efforts in Sichuan's frontier in the first half of the twentieth century were not unmitigated failures. Indeed, as I will show in chapter one, in a certain limited number of places, late Qing and Republican era governors built robust Han-dominated local administrations. The legacy of these administrations and their developmental projects is evident to this day. Judged by more realistic standards than the naive hopes of the era, and taking into account the immense difficulties of the late Qing and Republican periods, the Chinese engagement with the Sichuan highlands was often remarkably successful. This thesis is about that engagement and the forces that shaped it, both in the Qing and the Republican periods. These forces include: the visions that lay behind the late Qing expansion, the highland

\footnotetext{
${ }^{17}$ Liu Hengru et al., "Shicha Dao Lu De Bai Zhan Ya Jiang qi xian baogaoshu," 44.

${ }^{18}$ See Wang Chuan, "Jindai minzu guanxi shi shang de Xikang jian sheng ji qi lishi yiyi 近 代民族关系史上的西康建省及其历史意义," Xizang daxue xuebao 西藏大学学报 23, no. 1 (2008): 60-70; Huang Tianhua 黄天华, "Lun minguo shiqi Xikang jian sheng 论民 国时期西康建省," Sichuan shifan daxue xuebao 四川师范大学学报（社会科学版）28, no. 4 (2001): 95-100.
} 
environment, pre-existing frontier institutions and the broader political, economic and intellectual milieu.

Most chapters of this thesis examine the development of regional and local level Han-dominated state institutions: from county governments (xianfu 縣府) and their staff, to the regional military forces and civil governments, as well as the various organizations they established, such as the Xikang Provincial Agriculture Improvement Institute (Xikang sheng nongye gaijin suo 西康省農業改進所). China scholarship has often been uncertain as to whether to categorize regional "warlord" regimes, such as Liu Wenhui's, as part of “the state” or not. Mary Backus Rankin writes:

State authorities were only one of a long list of political actors that included central officials, provincial leaders, local officials, members of elite civic and voluntary organizations, publishers and journalists, warlords and their armies, revolutionaries and their forces, and loosely organized students in urban centres. Instead of clear dichotomies between state power and social action, there were shifting intersections between different processes of bureaucratic centralization, militarization, elite civic participation or nationalist protestation. ${ }^{19}$

But the "warlords" did much the same things as the "state authorities". They aimed to monopolize coercion within their territories, and they paid for it by taxing the population. Given that "the state" was not a cohesive, unitary and clearly delineated entity in the Republican period is the concept valuable for historians of that era? Would it be easier to name specific institutions without using the potentially confusing notion of "the state"?

Despite Rankin's warning about posing dichotomies between state and society, there is a strong tendency for scholars—including Rankin — to use the idea of the state, and I do not believe they are wrong to do so. Timothy Mitchell has argued that although the state is not "a free-standing entity [...], located apart from and opposed to another entity called economy or society”,

\footnotetext{
${ }^{19}$ Mary Backus Rankin, "State and Society in Early Republican Politics, 1912-18," in Reappraising Republican China, ed. Frederick Jr Wakeman and Richard Louis Edmonds (Oxford: Oxford University Press, 2000), 7.
} 
it does not follow that scholars should discard the notion entirely. ${ }^{20}$ The effect of a separate and distinct state is one of the key characteristics of modern politics (and not a few pre-modern political contexts). ${ }^{21}$ This effect has been created by the accumulation of many small practices and interventions that Mitchell and Foucault call "disciplines". ${ }^{22}$ These are things such as barracks, which physically separate the space inhabited by 'state' soldiers and the rest of 'society'; as well as items like uniforms, insignia, passports and 'political' maps, all of which make manifest an otherwise abstract state entity.

The Han-dominated government and military institutions in the late Qing and Republican era Sichuan highlands demonstrate the creation of a stateeffect as described by Mitchell. The authors of the sources used by this study perceived those institutions as constituting a series of integrated governmental organizations connected to a larger "Chinese state”. Those connections to national centres of authority certainly existed, though they were more tenuous than many writers perceived or admitted. Within local politics, the dividing line between state and non-state was at times unclear, and was drawn in different ways. One of Ningshu's most important martial leaders in the mid and late Republican periods was the bi-cultural Deng Xiuting 鄧秀廷. One section of a 1939 report referred to Deng's fighters as “government/state soldiers” (guan bing 官兵), yet in the same report’s summary of local armed-groups, Deng was listed under "private forces” (siren shili 私人勢力), as opposed to “security forces” (bao'an tuandui 保安 團隊), which the writer presumably saw as government organizations. ${ }^{23}$ But

\footnotetext{
${ }^{20}$ Timothy Mitchell, "Society, Economy, and the State Effect," in The Anthropology of the State: A Reader, ed. Aradhana Sharma and Akhil Gupta (Malden, MA: Blackwell, 2006), 184.

${ }^{21}$ Ibid., 184-5.

${ }^{22}$ Ibid., 177. Mitchell is drawing on Michel Foucault and Colin Gordon, Power/knowledge: selected interviews and other writings, 1972-1977/Michel Foucault; edited by, Colin Gordon ; translated by Colin Gordon ... [et al.] (Brighton, Sussex: Harvester Press, 1980); Graham Burchell, Colin Gordon, and Peter M. Miller, eds., The Foucault Effect: Studies in Governmental Nationality: with two lectures by and an interview with Michel Foucault (London: Harvester Wheatsheaf, 1991).

23 "Ningshu diaocha baogao huibian", 1939, (unpublished manuscript, held at Peking University library), junshi men 軍事門, 59; zhengsu men 政俗門, 27.
} 
even though his categorization of Deng was more ambiguous than others', this writer still saw a distinction between "private armed forces" and those that seemed more clearly associated with the regional government.

On occasion the state-effect did break down altogether, as when one of the writers of a report commissioned by the Guomindang in 1939 commented that "bandits and soldiers are one and the same thing (bing ye, fei ye兵也, 匪也)”. ${ }^{24}$ But in general, the Sichuan Frontier Defence Force (Chuan-Kang bianfangjun 川康邊防軍, in 1927 absorbed into Liu Wenhui's Twenty Fourth Revolutionary Army, as his forces were known in Guomindang nomenclature) was perceived as a government organization, not a group of bandits. It still broke the law, for example, by selling opium. Arguably its infringement in this area was a much greater crime than anything bandit gangs could accomplish. But the state-effect was strong enough that almost all sources considered it a government army, not a bandit gang. While I have endeavoured to be specific about historical agents, I have also at times used the notion of the "Han state in the highlands" as shorthand for the network of regional and local Han dominated institutions that generally presented that effect of being a relatively distinct governing structure.

\section{Sources}

The section of this thesis concerned with Qing policy and ideology draws mostly on correspondence written by Zhao Erfeng and the officials who

\footnotetext{
${ }^{24}$ Guomin canzheng hui. Chuan kang jianshe shicha tuan 國民參政會. 川康建設視察團, ed. Guomin canzhenghui Chuan-Kang jianshe shichatuan baogao shu 國民參政會川康 建設視察團報告書 (Taibei: Wenhai chubanshe youxian gongsi,1971 [1939], hereafter, CKSB), 141.
} 
worked for him. ${ }^{25}$ The other key source for this period is the 1912 account of Zhao's campaigns written by Fu Songmu, Zhao's deputy and successor. ${ }^{26}$

For the Republican period there is a greater variety of sources. I have used archival material stored in the Sichuan Provincial Archives, and published compilations of documents in this and other archives. The Republican period also saw the publication of a large volume of writing on the frontier region. Most of this work appeared in journals such as Kham Guide Monthly or Xikang Economy Monthly (Xikang jingji yuekan 西康經 濟月刊), though around a dozen reports were also published in book form. This body of writing includes both travel narratives and more systematically planned research, though many works straddled both these categories.

One individual, Ren Naiqiang 任乃強 (1894-1989), merits a special introduction due to the key role he played in the Han project to govern and produce knowledge about the Sichuan frontier. Moreover, although Ren was a much more prolific writer than his colleagues, his general career path was not untypical for Han engaged with Xikang during his time. Ren was born in Nanchong 南充, Sichuan, and attended Beijing Agricultural College from 1915. ${ }^{27}$ After graduation he worked for a Beijing newspaper, before returning to Nanchong to serve as the director of the local Bureau of Industry and Commerce and the director of middle school education. In 1928 he wrote what one biographer calls "the first modern, systematic account” of the histories of the ancient Shu 屬 and Ba 巴 kingdoms. ${ }^{28}$ In 1929, Hu Ziang 胡子昂, the chief of the Border Affairs Office at the headquarters of the Frontier Defence Force, appointed Ren as an official

\footnotetext{
${ }^{25}$ Collected in: Zhao Erfeng 赵尔丰 and Wu Fengpei 吴丰培, Zhao Erfeng Chuan bian zou $d u$ 赵尔丰川边奏牍 (Chengdu: Sichuan minzu chubanshe, 1984); Sichuan minzu yanjiu suo 四川民族研究所, ed. Qing mo Chuan Dian bianwu dang'an shi liao 清末川滇边务 档案史料, 3 vols., vol. 1 (Beijing: Zhonghua shuju,1989, hereafter QCBD).

${ }^{26}$ Fu Songmu 傅嵩炑, Xikang jiansheng ji 西康建省記, 3 vols., vol. 1 (Beijing: Zhongguo Zang xue chubanshe, 1988 [1912]).

${ }^{27}$ Unless otherwise noted biographical information on Ren is from: Li Yuanyuan 李垣垣, ed. Minguo Chuanbian youzong zhi "Xikang zhaji" 民國川邊游踀之『西康札記』 (Beijing: Zhongguo Zangxue chubanshe, 2010), un-paginated preface.

${ }^{28}$ Ibid.
} 
Border Region Investigator (bianqu shicha yuan 邊區視察員). ${ }^{29}$ Funded by the Border Affairs Office, Ren spent a year in Kham conducting research. ${ }^{30}$ On the basis of his investigations and with the help of his Tibetan wife, Ren compiled reports on eleven Kham counties and produced a monograph called Notes on Xikang (Xikang zhaji 西康札记). ${ }^{31}$ In 1929, Liu Wenhui appointed Ren as a member of the Economic Construction Committee (Jingji jianshe weiyuanhui 經濟建設委員會) of the Twenty Fourth Army. At the same time, Ren revised his work for serialized publication in the Sichuan Daily (Sichuan ribao 四川日報) newspaper, and in 1932 he did the same for the magazine New Asia (xin Yaxiya 新亞細亞), which published it as Xikang tujing 西康圖經. ${ }^{32}$ Reviews praised this work as "the best new gazetteer (zhi 志) of a frontier region” and a "pioneer work for research on Tibet."33

Ren was appointed to Liu Wenhui’s Preparatory Committee of Xikang Province (Xikang jiansheng weiyuanhui 西康建省委員會) when it was established in 1935. He later became the director of the Xikang CountyGovernment Officer Training Bureau, where he also taught a course on Tibetan history. After the region ascended to full province-hood, he began work on a Xikang gazetteer, though this was never finished. From 1943 he was a professor working on frontier research at West China Cooperative University (Huaxi xiehe daxue 華西協和大學) in Chengdu. In this role he spent a lot of time traveling, especially in Liangshan, a part of the frontier he had hitherto neglected. After 1945, he worked at Sichuan University, where he raised funds to establish a Kham and Tibet Research Society

\footnotetext{
${ }^{29}$ Chen Chunlei 陈春雷, "Xikang guiyi lu de laiyou 《西康论异录》的来由," Dushu 读书 , June 2006, 145.

${ }^{30}$ Ibid.

${ }^{31}$ Wang Chuan, "Jindai minzu guanxi shi shang de Xikang jian sheng ji qi lishi yiyi 近代民 族关系史上的西康建省及其历史意义," Xizang daxue xuebao 西藏大学学报 23, no. 1 (2008): 38.

${ }^{32}$ Chen Chunlei, "Xikang guiyi lu de laiyou," 145.

${ }^{33}$ Ibid.
} 
(Kang Zang yanjiu she 康藏研究社), which published Tibet and Kham Studies Monthly.

Ren had some knowledge of the local Xikang languages, although he was not completely proficient in their use. ${ }^{34}$ He commented that the Xikang languages are "easy to learn but difficult to master" and provided readers with some introductory sentences in Xikang tujing. ${ }^{35}$ According to Ren, all the Han who went to Xikang soon learnt such phrases and, after one or two years, could conduct conversations in the local tongues. ${ }^{36}$ (Those in higher leadership posts appear to have been the exception: "It is unheard of for Han governors to be able to understand Fan [Tibetan] languages.”37)

Ren read most secondary literature on Xikang that was available in both Chinese and English. In Xikang tuijing, he quoted Eric Teichman's (18841944) Travels of a Consular Officer in Eastern Tibet and Charles Bell's (1870-1945) Tibet: Past and Present. He commented that there were no more detailed accounts of the region than Teichman's and largely agreed with Teichman's explanation for the failures of colonization schemes. ${ }^{38}$ Bell, by contrast, was castigated as one of the "fierce invaders of Tibet” (qinlüe Xizang zhi zui mengjin zhe 侵略西藏之最猛進者) ${ }^{39}$, although he recommended that Bell's English-Tibetan dictionary be translated and published in China. ${ }^{40}$ He also referred to Oliver Coales and the Germans Ryder and Richthofen. ${ }^{41}$

Ren's main patron was Liu Wenhui's regional government. Other bodies also commissioned research on the Sichuan frontier. In 1939 the

\footnotetext{
${ }^{34}$ Ren Naiqiang, Xikang tujing: minsu pian 西康图经: 民俗篇 (Shanghai: Shanghai shudian, 1996 [1933]), 204.

35 Ibid.

${ }^{36}$ Ibid., 204, 29.

${ }^{37}$ Ibid., 225.

${ }^{38}$ Ren Naiqiang, Xikang tujing: diwen pian 西康图经: 地文篇 (Shanghai: Shanghai shudian, 1996 [1933]), 27; Xikang tujing: minsu pian, 255.

${ }^{39}$ Ren Naiqiang, Xikang tujing: jingyu pian 西康图经: 境域篇 (Shanghai: Shanghai shudian, 1996 [1933]), 53.

${ }^{40}$ Ren Naiqiang, Xikang tujing: minsu pian, 217.

${ }^{41}$ Ren Naiqiang, Xikang tujing: diwen pian, 26-27.
} 
Guomindang organized an investigation team to visit the region for some months, as one branch of a broader survey of Sichuan. The mid-1930s journal Sichuan Frontier Quarterly was sponsored by the Bank of China in Chongqing. As with all historical sources, it is reasonable to expect that the sponsoring organization had some degree of subtle or not-so-subtle influence over the finished product. It would be wrong, however, to view these sources as mere mouthpieces of state authority. For one thing, the Guomindang did not have much to do with Liu Wenhui’s Xikang regime. There is no reason to think that the provincial authorities could influence what was published outside Xikang very much, and outside sources had no particular reason to be kind to Liu's provincial government.

Finally, there are the sources written by foreign travellers, a group mostly made up of missionaries, geographer-adventurers, consuls and refugees from troubled Europe, who were present in quite large numbers relative to other parts of inland China.

\section{Previous scholarship}

This thesis can be situated within the parameters of different levels of history writing. Firstly and most directly, there is the relatively limited corpus of work on the Sichuan frontier region in the late Qing and Republican periods, the vast majority of which focuses on Kham, rather than Ningyuan/Ningshu. At a broader level, there is the flourishing body of writing about non-Han regions within the Qing and post-Qing states. Another relevant historiography at roughly the same level consists of writing about Chinese modernity. These historiographies connect to a still broader scholarship that relates to states, frontiers and modernity in the last few hundred years of world history.

Where the history of the Sichuan frontier highlands in the late Qing and Republican period has been studied before, the emphasis has primarily been upon key leaders and their relationships with each other, often as shaped by various species of nationalism and regionalism. James Leibold has discussed the ideologies of the Guomindang and the Xikang provincial 
government, and the tri-polar relationship of these two bodies and the Lhasa government. ${ }^{42}$ Hsiao-ting Lin has examined the vicissitudes of Guomindang policy towards Tibetan governments. ${ }^{43}$ Peng Wenbin has analyzed indigenous self-rule movements, focusing particularly on the role of key actors such as Kesang Tsering and the Panchen Lama's retinue. ${ }^{44}$ Of the Qing period, Xiuyu Wang has provided a thorough introduction to Qing campaigning in Kham and there have been a few other succinct but good discussions of Zhao Erfeng's campaigns and his main aspirations. ${ }^{45}$ Chinese language scholarship has produced a tidy body of research on Zhao Erfeng and some isolated studies of the region in the Republican period. ${ }^{46}$ Much of this new Chinese scholarship is impressive, despite the influence of nationalist concerns identified above.

This thesis differs from and complements this body of work by concentrating on the details of developmental agendas and activity, and the forces that shaped them, rather than on relationships between political actors. Of course, those relationships were an important influence on policy. But as we shall see, they were not the only influence. It is also the first study-in either Chinese or English-to take in the connections and contrasts between Kham and Ningshu, and the first to pay attention to continuities and changes over the whole of the first half of the twentieth century.

\footnotetext{
42 James Leibold, Reconfiguring Chinese Nationalism: How the Qing Frontier and its Indigenes Became Chinese (New York: Palgrave Macmillan, 2007).

${ }^{43}$ Lin, Tibet and Nationalist China's Frontier.

${ }^{44}$ Peng Wenbin, "Frontier Process, Provincial Politics and Movements for Khampa Autonomy During the Republican Period," in Khams Pa Histories: Visions of People, Place and Authority, ed. Lawrence Epstein (Leiden; Boston: Brill, 2002): 57-84.

${ }^{45}$ Wang Xiuyu, "China's Last Imperial Frontier"; Sperling, "The Chinese Venture in K'am"; David Dahpon Ho, "The Men Who Would Not Be Amban and the One Who Would: Four Frontline Officials and Qing Tibet Policy, 1905-1911," Modern China 34, no. 2 (2008): 210-46; William M. Coleman, "The Uprising at Batang: Kham and its Significance in Chinese and Tibetan History " in Khams Pa Histories: Visions of People, Place and Authority ed. Lawrence Epstein (Leiden: Brill, 2002): 31-56.

${ }^{46}$ For example, Wu Yanqin 吴彦勤, Qing mo min guo shiqi Chuan Zang guanxi yanjiu 清 末民国时期川藏关系研究 (Kunming: Yunnan renmin chubanshe, 2006); Ma Jinglin 马 菁林, Qing mo Chuanbian Zang qu gaitu-guiliu kao 清末川边藏区改土归流考 (Chengdu: Sichuan chuban jituan, 2002); Wang Chuan, "Jindai minzu guanxi shi shang de Xikang jian sheng ji qi lishi yiyi".
} 
The volume of research within the second concentric ring of scholarship identified above, that concerned the non-Han regions of the Qing and its successor states, has grown significantly in the last two decades. Scholars have long recognized that, in most cases and for most of the time, the rulers of the Qing Empire were highly flexible in their approach to governing the different regions of their dominion. In Chinese language political discourse there was a basic distinction between the "interior lands" (nei di 內地)—the Han Chinese dominated territory often called "China proper" in English— and the “outer lands” (wai di 外地), such as Xinjiang, Tibet and Manchuria. For the most part, these large component parts of the empire were governed according to different systems, in ways that adapted to indigenous social and political traditions. The idea of spreading institutions and culture from the Han world to certain non-Han regions also existed, particularly in the Yongzheng 雍正 (r. 1722-1735) and Jiaqing 嘉慶 (r. 1796-1820) reigns, but its impact was relatively limited. ${ }^{47}$ This aspiration gained much greater and more widespread traction in the late Qing. James Millward demonstrates that there was a "fundamental shift in governing principles" during the nineteenth century that saw attempts to establish junxian administration and propagate Chinese culture throughout the outer lands. ${ }^{48}$ The campaigns in the Sichuan frontier were clearly connected to this broader decline of a flexible approach to governance. The reasons for this wider shift are not well understood, and though a full explanation is beyond the remit of this thesis, it is a problem to which I return at various points.

Many historical accounts describe the degree of difference that existed in frontier territory after attempts to establish junxian government and spread Chinese culture as a matter of the success or failure of these attempts. Or, from the perspective of the indigenous people, difference becomes a matter of their acculturation, adaptation or resistance to Chinese ways. James Reardon-Anderson describes the Han colonization of Manchuria as success

\footnotetext{
${ }^{47}$ Yang Minghong 样明洪, "Lun Qingdai Liangshan Yi qu de tusi zhidu yu gaituguiliu 论 清代凉山彝区的土司制度与改土归流," Minzu yanjiu 民族研究, no. 2 (1997): 94.

${ }^{48}$ James A. Millward, Eurasian Crossroads: A History of Xinjiang (New York: Columbia University Press, 2007), 138.
} 
on the sinicization front. There was a "wholesale importation of an essentially Chinese society, economy, and culture."49 Yunnan was clearly different, but the key variables were the same. Of eighteenth and nineteenth century Yunnan, C. Patterson Giersch writes:

Cultural borrowings [from Han culture by non-Han] represented a process of acculturation - the creative and selective adaptation of another society's practices, rather than the wholesale imitation of another's full cultural repertoire. ${ }^{50}$

These fine histories give good accounts of social change in Manchuria and Yunnan. But they do not tackle variation on the Chinese side of the equation. This can give the impression that non-Han societies either resisted, or were partially or fully overlaid by, some kind of prototypical Han Chinese society and political order.

However, historians of the development of the modern Chinese state have frequently pointed to the considerable local variation that characterized Chinese state-building. ${ }^{51}$ Given that this process followed different courses in different regions within China proper, what exactly were the frontiers acculturating or assimilating to? In part, the regional diversity of local state making was a product of the fragmentation of the Republican era. But this was certainly not the only cause. Elizabeth Remick argues that regional variation in this period came about not only because a weak central government was unable to fully control local authorities, but also because local state builders operated under the constraints of different local contexts and had different priorities and ideologies. ${ }^{52}$ Moreover, in the late nineteenth and early twentieth centuries, central governments themselves

\footnotetext{
49 James Reardon-Anderson, Reluctant Pioneers: China's Expansion Northward, 16441937 (Stanford: Stanford University Press, 2005), 7.

${ }^{50}$ C. Patterson Giersch, Asian Borderlands: The Transformation of Qing China's Yunnan Frontier (Cambridge, Mass.: Harvard University Press, 2006), 188.

${ }^{51}$ Elizabeth J. Remick, Building Local States: China during the Republican and post-Mao eras (Cambridge, Mass.: Harvard University Asia Center, 2004); Xin Zhang, Social Transformation in Modern China: The State and Local Elites in Henan, 1900-1937 (Cambridge: Cambridge University Press, 2000).

52 Remick, "The Significance of Variation in Local States: The Case of Twentieth Century China," Comparative Politics 34, no. 4 (2002): 405.
} 
contributed to the growth of diversity by moving away from a model under which wealthier regions subsidized the development of poorer ones, to "a de facto policy of 'picking winners'”. ${ }^{53}$ Thus, at exactly the same time as Chinese administrations formulated policy aimed at eliminating frontier difference, central government policy began to allow for a greater separation of hinterlands and core regions within interior China. This leaves the challenge of understanding the simultaneous vanishing or acculturation of frontiers and the "making of hinterlands".

We arrive now at the largest concentric ring of historiography; that concerned with the modern history of state-building and settlement in territory that is peripheral, new or frontier-like from the perspective of expanding polities. Both Chinese and Western historians often cast the late Qing government's efforts to transform their empire's periphery as fundamentally connected to the 'age of high imperialism'. Two distinct links are made. Firstly, as Kenneth Pomeranz argues with respect to Manchuria, "the new political calculus forced upon China by the age of high imperialism made the logic of encouraging expanded settlement and rapid development [...] irresistible.” ${ }^{54}$ Secondly, as we shall see, many historians have argued that the Zhao Erfeng's efforts in Kham bear the intellectual influence of Western colonialism. According to such explanations, Xikang's development is best understood as the result of global political circumstances and developments. The alternative is to see it as the result of developments within China, or even southwest China, that were not strongly related to the formation of European empires in Asia. That both global and local contexts were important is a true but pretty banal observation. The important questions are which factors in the global picture should be connected to which events in the Sichuan frontier, and how much causal power should be assigned to them. This thesis does not provide comprehensive answers to these questions, something that would require

\footnotetext{
53 Kenneth Pomeranz, The Making of a Hinterland: State, Society and Economy in Inland China, 1853-1937 (Berkeley: University of California Press, 1993), 275.

${ }^{54}$ Pomeranz, "Is There an East Asian Development Path? Long-Term Comparisons, Constraints, and Continuities." Journal of Economic and Social History of the Orient 44, no. 3 (2001): 337.
} 
investigation of issues that are beyond its already relatively broad scope. Yet it does seek to offer part of the foundations from which these questions can be approached, together with some preliminary observations and hypotheses.

\section{Outline of thesis}

Chapter one gives a broad overview of the development of Han local and regional authority in the highlands from 1905 to 1949. This chapter deals with one of the key established narratives: the notion, mentioned above, that the attempt to colonize the highlands was essentially a failure. I find that there were limits to failure, and areas of significant success. Hsiao-ting Lin's comment that Liu Wenhui's “so-called provincial regime was merely a foreign body to the Xikang natives with limited influence over infrastructure” is a good description of some places. ${ }^{55}$ But James Liebold's notion of Xikang as Liu's “fiefdom” gives a more accurate impression of others. ${ }^{56}$ The narrative of a general collapse in the Republican period also needs refining in order to identify the specific times and causes of regional Han government weakness. As I demonstrate, the nadir for Chinese engagement with the highlands came not immediately after the 1911 revolution but in the late 1910s and early 1920s. Decline in this period was caused primarily by the Yunnanese occupation of Sichuan and consequent budget cuts to Sichuanese garrisons. From the mid-1920s, there was a revival of Han regional and local state power in certain areas in the east of the highlands under the leadership of Liu Wenhui. This was due to several factors: Firstly, Liu's willingness to commit resources to the region before 1933; secondly, his having no choice about doing so after 1933; thirdly, the subsidies his government received from the central government; and fourthly, the profit he derived from opium exports from the mid-1930s.

\footnotetext{
${ }^{55}$ Lin, Tibet and Nationalist China's Frontier, 68.

${ }^{56}$ Leibold, Reconfiguring Chinese Nationalism, 69.
} 
Chapter two focuses on the late and hasty Qing engagement with the Sichuan frontier. Elliot Sperling has summarized Zhao Erfeng's policy as having the aim of "sinicizing" Kham as far as possible. ${ }^{57}$ At the broadest level, this is correct. But there was no single Chinese society for Zhao to copy and transplant. In 1905, China and Chinese history furnished a myriad of possible models for the frontier administration. Which were the most important influences? Most scholars have constructed Zhao as a modernizer. This raises the question of whether there a tension between "sinicization" and modernity in the plan for a new Kham. In fact, as I will argue, Zhao mostly drew conservatively on early and high Qing models of frontier rule. He could only be called a modernizer if those precedents themselves are admitted as “modern” (or at least “early-modern”). A lot of new scholarship on the Qing has moved towards suggesting exactly that, but this still requires us to acknowledge Zhao's brand of modernity was a relatively conservative one.

Chapter three addresses issues relating to continuity and change in the Republican period. The general mission to transform the highlands and ensure their integration into the Chinese nation-state was clearly a goal for Chinese officials throughout the period under investigation. There have been many other areas of continuity as well. From the late Qing to the end of the Republican period, all regional Han authorities prioritized spending on Kham above Ningshu. Republican period settlement societies implemented the same kind of settlement systems as that adopted by Zhao Erfeng. Republican period authorities also promulgated similar laws regarding land ownership to those made by Zhao. However, it is here that we also encounter one of the significant differences. Despite proclaiming that "wasteland" belonged to the state, Republican period authorities made almost no attempt to actually appropriate any wasteland, and even the provincial government's own agricultural enterprises rented land officially categorized as "wasteland" from private owners. This change was due to several factors, but most notably to shifts in local and provincial government sources of revenue. The Republican era saw other changes in

\footnotetext{
${ }^{57}$ Sperling, "The Chinese Venture in K'am," 20.
} 
the realm of agriculture too. Liu Wenhui's regime created an agricultural development strategy that was very different from Zhao Erfeng's. It pursued different kinds of agriculture, through different organizational forms, toward slightly different goals.

Chapters four and five address the influence of local environments and institutions on the development of regional Chinese authority. The regional and local Chinese governments in the highlands were not copies of generic Chinese source material. Instead, they were powerfully influenced by local issues and officials' responses to them. Chapter four focuses on Kham, and in particular the Inner Asian institution of the wula 烏拉 corvée labour tax, which was levied by regional Han military units and governors in Kham. The problems associated with the tax came to constitute the most critical set of dilemmas they faced in that region. Their attempts to resolve these problems powerfully shaped their developmental agendas as well as their relations with indigenous leaders, and left a legacy that exists to this day. Chapter five focuses on Ningshu. Here, there was no wula tax, but other pre-twentieth century institutions had an effect of similar magnitude. Security contracting arrangements between indigenous chiefs and Chinese local authorities that had been forged in the nineteenth century broke down violently in the late 1910s with important consequences for the subsequent development of politics and society in the region.

Chapter six examines Han migration to the highlands. In some places in the east of the highlands there was a significant increase in the Han population. While this was not the explosive colonization that many governors and Chinese intellectuals hoped for, it was in marked contrast to demographic stagnation in the Sichuan basin, and decline on the eastern fringe of the basin. One of the primary reasons for going to the western highlands was that real wages for unskilled labour were higher there than in the Sichuan basin. A nationalist ideology that promoted settlement in the borderlands was also important in some cases.

Finally, chapter seven gives a broad analysis of Chinese discourse about transforming the Sichuan frontier, taking in the Qing and Republican periods, and providing some preliminary observations about the survival, development or disappearance of ideas from those eras in the present day. 
This chapter examines leaders' discussion of the kinds of changes believed to be necessary, as well as narratives of the past that have posited certain kinds of transformations as historically significant. Four kinds of transition have been at the heart of discourse on change in the twentieth century. These are: the settlement of the highlands by Han people, a moral reformation of government, economic modernization, and the assimilation of the indigenous people. Yet these things have meant quite different things to different people. Moreover, rarely have all four been part of the same vision, and there has been considerable disagreement as to whether all are equally necessary.

\section{Omissions and limits}

Geographically, this thesis concentrates on the territory within the Qing Jianchang Circuit, most of which became Xikang province. Certain places on the eastern edge of the Liangshan range, Mabian and Leibo, were part of the Jianchang circuit but not Xikang. They warrant inclusion in this project because they were conceptualized as being part of the Sichuan frontier, and because in their economy, geography, history and ethnic composition they were closer to Ningshu than the Sichuan basin. Today, Leibo is a part of the Liangshan Yi Autonomous Prefecture that has succeeded Ningshu as the regional administrative unit. Arguably what is today the Aba Tibetan Autonomous Prefecture, which was neither part of Jianchang nor Xikang province, but shared obvious similarities with the parts of Kham that were, should also be included for similar reasons. However, the scope of this thesis is already rather large, and I have decided to leave Aba for future studies. In addition, this thesis does not deal much with the places within Jianchang/Xikang that have been dominated by Han populations since at least the mid-Qing, such as Xichang and Ya'an. This is because this project is concerned primarily with frontier-ness; that is with new settlement and attempts to establish new administrations.

As a study of Han engagement with the region, it draws mostly on Chinese language primary source material. I have made supplementary use 
of accounts written by Western travelers. There are probably accounts written in indigenous languages - Tibetan and $\mathrm{Yi}$ - which would have been useful as well. However, my limited ability in these languages, combined with the greater difficulties in finding and accessing any such sources has excluded them. It is my hope that other scholars will locate such sources and use them to approach the topics covered in this project from indigenous perspectives. 


\section{Chapter One: The Rise and Fall and Rise of Chinese Authority in the Sichuan Frontier, 1905-1949}

This chapter gives an overview of the development of Chinese state authority in the Sichuan frontier in the first half of the twentieth century. Though governors often failed to achieve their own ambitious goals, they nonetheless succeeded in some places in establishing a rudimentary administration that wielded effective power at a local level. In the last decade of the Qing dynasty, indigenous chiefdoms were replaced with county bureaucracies managed by Han officials across large parts of the frontier region for the first time in history. This administration did survive the 1911 revolution, but the Han presence in the highlands suffered greatly in 1917 when Sichuan was occupied by the Yunnanese army. It recovered in the 1920s, and Chinese frontier state authority became remarkably strong in a limited number of locations in the 1930s and 40s. This regional state had several sources of support, but the two most significant were outside subsidies and opium.

Qing engagement with Chuanbian, 1895-1911.

In $1895 \mathrm{Lu}$ Chuanlin 鹿傳霖 (1836-1910), then governor of Sichuan, led military campaigns in parts of Kham and argued for them to undergo gaituguiliu 改土歸流: the replacement of indigenous chiefs with the administration system that governed interior China. The court rejected his proposal. ${ }^{1}$ In $1897 \mathrm{Lu}$ was dismissed for embezzling funds and mismanagement of the frontier. ${ }^{2}$ As a favourite of the Empress Dowager, he secured an appointment as a grand councillor and continued to publish his

\footnotetext{
${ }^{1}$ S. A. M. Adshead, Province and Politics in Late Imperial China: Viceregal Government in Szechwan, 1898-1911 (London: Curzon Press, 1984), 57.

${ }^{2}$ Ibid., 18.
} 
views on frontier governance. ${ }^{3}$ The central government gaitu-guiliu-ists did not limit their program for reform in the southwest to Kham. Another grand councillor, Yin Kechang argued for the removal of all tusi in Yunnan and Sichuan and the establishment of a new Jianchang Province in the upland territory of the two provinces. ${ }^{4}$ In April 1903, the Mongol Xiliang 錫良 (1853-1917) was appointed as the new governor of Sichuan. Lu Chuanlin admired and supported Xiliang though the protégée was much more riskaverse than the mentor. Arriving in Chengdu, Xiliang professed that he "knew nothing about Tibet". ${ }^{5}$ But whatever he had heard made him doubt the feasibility of the colonial program for the highlands, and he made no immediate moves in that direction. ${ }^{6}$

The British invasion of Tibet, which began in late 1903 and reached Lhasa in August 1904, played into the hands of the reformist faction. Yet in one of his first memorials after the British expeditionary force left Gnatong in Sikkim for Tibet, Xiliang continued to insist that "commerce, mining and agricultural settlement are not solutions to the dire situation in Tibet". Despite such strong reservations, he was willing to initiate trial efforts in these areas on a very limited scale. "Plans will be made for a farm [at Bathang], but only using around one square $l i$ of land”. ${ }^{8}$ Moreover, he "still resisted pressure to undertake a military build-up in Kham.” ${ }^{9}$ Xiliang gave the new assistant resident in Tibet, Fengquan 鳳全 (the former chief of the Chengdu police), only 150 guards rather than the large garrison Fengquan

\footnotetext{
${ }^{3}$ Ibid., 58.

${ }^{4}$ Yang Minghong, "Lun Qingdai Liangshan Yi qu de tusi zhidu yu gaituguiliu, 94.

${ }^{5}$ Roger V. Des Forges, Hsi-liang and the Chinese National Revolution (New Haven: Yale University Press, 1973), 72.

${ }^{6}$ Adshead, Province and Politics in Late Imperial China, 58.

${ }^{7}$ Sichuan minzu yanjiu suo 四川民族研究所, ed. Qing mo Chuan Dian bianwu dang'an shi liao 清末川滇边务档案史料, 3 vols., vol. 1 (Beijing: Zhonghua shuju, 1989, hereafter QCBD), 4. The British army left Gnatong for Tibet on 11 December 1903. Xiliang's memorial was dated 17 December, and was a response to a proposal relayed from the Grand Council. It is not clear how much Xiliang knew about the intentions of the British—the army in Gnatong would certainly have seemed threatening, however.

${ }^{8}$ Ibid.

${ }^{9}$ Des Forges, Hsi-liang and the Chinese National Revolution, 74.
} 
had requested. ${ }^{10}$ Fengquan's “arrogant and harsh” disposition got the better of any caution his weak force had lent him; having thoroughly antagonised the Bathang locals, he was killed in April 1905. ${ }^{11}$ Revolt spread to other parts of Kham and also claimed the lives of two French priests and their converts. ${ }^{12}$ This forced Xiliang to take more decisive action. He sent his own protégé Zhao Erfeng together with Ma Weiqi 馬維騏 (1846-1910) and a force of either 2,000 or 4,000 men (sources differ) to quell the rebellion. ${ }^{13}$

Thus the significance of the British invasion is a more open question than many scholars have assumed. ${ }^{14}$ The foreign imperialist threat undoubtedly strengthened the hand of the gaitu-guiliu-ists. But that faction had existed before the British arrived. Furthermore, the revolts in which Fengquan and

${ }^{10}$ Ibid.

${ }^{11}$ Wang Xiuyu gives the most detailed analysis of the events that led to Feng's killing: Wang Xiuyu, "China's Last Imperial Frontier," 119-30.

${ }^{12}$ Des Forges, Hsi-liang and the Chinese National Revolution, 76.

${ }^{13}$ The figure of 2,000 is given by Des Forges; Ibid., 78.; William Coleman says 4,000; William M. Coleman, "The Uprising at Batang: Kham and its Significance in Chinese and Tibetan History " in Khams Pa Histories: Visions of People, Place and Authority ed. Lawrence Epstein (Leiden: Brill, 2002), 44. Des Forges's figure may by just troops led by Zhao Erfeng, i.e. not including troops commanded by Ma Weiqi or native troops supplied by the Mingzheng tusi (from Dartsedo). According to Wang Xiuyu, Zhao led a force of 2,500 soldiers, and Ma Weiqi had also led a force of an equivalent size. Some of Ma's soldiers might have been assigned to Zhao, however. Wang Xiuyu, "China's Last Imperial Frontier", 77.

${ }^{14}$ Melvyn Goldstein, for example, writes: "whatever the tenuous nature of Tibet-Chinese relations before the twentieth century, three events in the first eleven years of this century dramatically altered the status quo: (1) the growth of British interest and relations with Tibet, culminating in the successful invasion of Tibet and Lhasa [...] (2) the consequent efforts of the Chinese to reestablish control over Tibet, culminating in the military occupation of Lhasa in early 1910 by the Chinese general Chung Yin; and (3) the Chinese overthrow of the Manchu dynasty in 1911 and the mutiny of Chinese troops in Tibet.” Melvyn C. Goldstein, A History of Modern Tibet, 1913-1951: the Demise of the Lamaist State (Berkeley: University of California Press, 1989), 44-45. Wang Xiuyu writes: "The new polices show an activation of colonialist ideas in Qing statecraft thought, motivated by countering British imperialism, by increasing Qing advantages in administration, revenue, military and cultural attraction.” Wang Xiuyu, "China's Last Imperial Frontier", 7. Chinese language scholarship tends to emphasize the importance of both the general threat of foreign imperialism to all China, and the specific threat of British imperialism to Tibet. The former is said to have produced the reform movements of which new policies toward the frontiers were a part, while the later was the proximate cause of the post 1905 campaigns. See for example Wu Yanqin 吴彦勤, Qing mo min guo shiqi Chuan Zang guanxi yanjiu 清末民国时期川藏关系研究 (Kunming: Yunnan renmin chubanshe, 2006). Li Maoyu 李茂郁, "Lun Zhao Erfeng 论赵尔丰," Shehui kexue yanjiu 社会科学 研究, no. 4 (2002); Ma Jinglin 马菁林, "'Gai tu gui liu" de hongguan lishi fenxi “改土归 流”的宏观历史分析," Xizang yanjiu 西藏研究, no. 3 (2001): 82-87. 
the foreigners were killed appear to have been more important in pushing Xiliang towards the hawks than the British expedition. Moreover, no case can be made that the similar course of events in Ningyuan (see below) was precipitated by the threat of foreign colonization.

Having put down the rebellion, Zhao was appointed to the new position of Warden of the Sichuan and Yunnan Marches created in August 1906. Even at this stage, Xiliang sought to "limit [the post's] effectiveness as regards both territorial scope and agenda," envisaging it as akin to that of the amban in Lhasa. ${ }^{15}$ In 1907, however, Xiliang was transferred to Yunnan, and Zhao Erfeng's brother Erxun 趙爾巽 (1844-1927) became the new governor of Sichuan. This gave Zhao Erfeng space to redefine his role in the frontier and set a new, much more radical agenda. Gaitu-guiliu was applied throughout the part of Kham that Qing administrative geography had apportioned to Yazhou Prefecture in 1725. ${ }^{16}$ In its aftermath, Zhao implemented a range of development policies; their focus and the ideology behind them is the subject of chapter two.

Aside from the absence of a foreign threat, the action in Ningyuan in the first decade of the twentieth century unfolded in similar manner. In the eighteenth century, there had been explosive Han settlement in areas of Ningyuan, particularly the Anning river valley. ${ }^{17}$ Probably because of this,

\footnotetext{
${ }^{15}$ Adshead, Province and Politics in Late Imperial China, 72-73.

${ }^{16}$ The British Consul Eric Teichman stated that by the end of the Qing dynasty, there was "not a Tibetan ruler left in eastern Tibet". Eric Teichman, Travels of a Consular Officer in Eastern Tibet; together with a History of the Relations between China, Tibet and India (London: Cambridge University Press, 1922), 33. This was not, strictly speaking, true, because there were still Tibetan rulers in places that had not been nominally part of Yazhou Prefecture, such as most of the modern day Aba Tibetan Autonomous Region, and also the Muli region of Ningyuan Prefecture.

${ }^{17}$ In 1711 Ningyuan Prefecture's total population was recorded at 12,500 people. In 1820 it was recorded as 1,266,273. Some of this increase no doubt came from within the Yi population, but Han migration was responsible for most of it Liu Zhenggang 刘正刚 and Tang Weihua 唐伟华, "Qing dai yimin yu Han Yi jiaoliu tantao 清代移民与汉彝交流探 讨," Guizhou minzu yanjiu 贵州民族研究 22, no. 90 (2002): 147. See also Lin Chengxi 林成西, "Yimin yu Qing dai Sichuan minzu diyu jingji 移民与清代四川民族区域经济," Xinan minzu daxue xue bao (renwen sheke ban) 西南民族大学学报 (人文社科版) 11, no. 183 (2006); Zhongguo shaoshu minzu shehui lishi diaocha ziliao congkan' xiuding bianji weiyuanhui 《中国少数民族社会历史调查资料丛刊》修订编辑委员会, ed. Sichuan sheng Liangshan Yizu shehui lishi diaocha (zonghe baogao) 四川省凉山彝族社 会历史调查（综合报告） (Beijing: Minzu chubanshe, 2009, hereafter SYSD), 83.
} 
gaitu-guiliu had been on the central government agenda at times before the twentieth century, notably during the reigns of the Yongzheng (r. 1722-1735) and Jiaqing (r. 1796-1820) emperors. ${ }^{18}$ However, due to several factors, including stiff indigenous resistance and a concern that removing tusi could make the Yi even less governable, it was rarely pursued widely or consistently (though under Yongzheng's general Ortai, it was certainly pursued ruthlessly). ${ }^{19}$ At the turn of the twentieth century gaitu-guiliu returned more forcefully to officials' attention. Nevertheless, as with Kham, there were no moves to overthrow the chiefs until the outbreak of conflict on the ground. The British adventurer John Brooke was killed in 1909 by Yi in a dispute over pay, after which Zhao Erxun dispatched an expedition against the Yi deemed responsible. ${ }^{20}$ In most histories, this campaign has been interpreted as a purely reactive move. ${ }^{21}$ One present-day historian argues that the Boxer Protocol left Zhao Erxun with no option but to undertake an aggressive response to the killing. ${ }^{22}$ However, given that many officials had been in favour of thorough reform before then, and that Zhao Erxun had allowed his brother to carry out such a program in Kham, another interpretation would be that Brooke's death merely provided an appropriate justification for action that Erxun wanted to undertake anyway. The Boxer Protocol may still have been important, but perhaps more as a rhetorical recourse for the gaitu-guiliu-ists in their arguments with conservatives who felt that costly intervention was unjustified.

\footnotetext{
${ }^{18}$ See Yingcong Dai, The Sichuan Frontier and Tibet: Imperial Strategy in the Early Qing (Seattle: University of Washington Press, 2009), 101-03.

${ }^{19}$ Yang Minghong, "Lun Qingdai Liangshan Yi qu de tusi zhidu yu gaituguiliu," 90-92. For Ortai’s campaigns, see Dai, The Sichuan Frontier and Tibet, 101-103.

${ }^{20}$ The death of Brooke has been mentioned by many sources and many of them are very unreliable and often get even Brooke's name wrong. The best account was written by his travelling companion, based (according to the writer) on the report of someone who was with Brooke when he died. W.N. Fergusson, Adventure, Sport and Travel on the Tibetan Steppes (London: Constable and Company, Ltd., 1911), 293-314.

${ }^{21}$ Chang Longqing 常隆慶, Lei Ma E Ping diaocha ji 雷馬峨屏調查記 (Chongqing: Zhongguo xi bu ke xue yuan, 1935), 13; Yang Minghong, "Lun Qingdai Liangshan Yi qu de tusi zhidu yu gaituguiliu," 94.

${ }^{22}$ Yang Minghong, "Lun Qingdai Liangshan Yi qu de tusi zhidu yu gaituguiliu," 94.
} 
It is also curious that the Boxer Protocol has been mentioned by the historians who have written about Liangshan, but not by those who have written about Kham. If the death of Brooke was an important factor in the provincial government's decision to use military force in Ningyuan, then surely the killing of the French missionaries in Kham was an equally significant cause of the unleashing of Zhao's campaign in that region. Alternatively, if the killing of the latter was unimportant, there is no reason to believe that Brooke's death was. In any case, Zhao Erxun's plan for Liangshan went well beyond punishing the Yi held responsible for Brooke's death and extracting from them any indemnity that the British might demand. The plan for the reconstruction of Ningyuan was very similar to that drawn up for Kham.

When it came to prioritizing where exactly efforts to implement such plans should be concentrated first, and at what stage they should be spread elsewhere, there was a certain amount of uncertainty. Before Zhao's arrival there were some significant development initiatives in Ningyuan. In 1899, the Qing government paid a local tusi 3,000 taels for rights to open a mine at Wali 瓦里. ${ }^{23}$ In 1903, the director of the Sichuan Minerals Bureau, Song Yuren 宋育仁 (1857-1931), employed foreign geologists to survey the region. ${ }^{24}$ There were also government efforts to increase Han Chinese settlement to Ningyuan. ${ }^{25}$ However, Zhao Erfeng consciously prioritized Kham above not only Tibet, but also Ningyuan. "When the Three Frontiers [san bian 三邊; Tibet, Kham and the Yunnanese highlands] have been pacified, then Ningyuan can be brought into the fold and county administration established there too. The pacification of Kham is the first step, however."26

\footnotetext{
${ }^{23}$ Ren Xinjian 任新建, "Jindai Sichuan Zang qu de huangjin kaifa 近代四川藏区的黄金开 发," in Sichuan Zangxue lunwen ji 四川藏学论文集, ed. Luo Runcang 罗润苍 and Ren Xinjian (Beijing: Zhongguo Zangxue chubanshe, 1993), 45.

${ }^{24}$ Ibid., 38.

${ }^{25}$ See for example Chongqing Zhongguo yinhang diaocha zuzhi 重慶中國銀行調查組織 (hereafter, ZYDZ), "Leibo diaocha 雷波調查," Chuanbian jikan 川邊季刊 1, no. 4 (1935): 109-10.

${ }^{26}$ Quoted in Ibid., 94.
} 
Ningyuan was not totally ignored under the watch of the Zhao brothers. The campaigns against the $\mathrm{Yi}$ held responsible for Brooke's death concluded with the implementation of gaitu-guiliu in the Zhaojue 昭覺 area and the establishment of Zhaojue County. The same year, work began on the construction of a road across the Liangshan mountains to connect Leibo and Xichang. ${ }^{27}$ Zhao Erxun ordered the construction of a fortress at Zhaojue at a cost of more than 20,500 taels. ${ }^{28}$ The next year there were more campaigns in the south of Ningyuan, accompanied by more gaitu-guiliu and a resolution from Zhao Erxun to “abolish Yi slavery,” and thoroughly reform Yi society. ${ }^{29}$

Despite such measures, during Zhao Erfeng's time in the frontier, military campaigning and state supported development programs were concentrated more heavily in Kham than Ningshu. There has been a fairly widespread view that this was a response to the situation in Tibet. Li Maoyu, for example writes:

The intensifying encroachment of Britain and Russia upon Tibet created an extremely precarious situation there. In order to reinforce Tibet, stave off the imminent danger and strengthen ties between Tibet and Sichuan, the Qing government had to take control of the Tibetan territory in the Sichuan frontier and implement gaitu-guiliu and direct administration of the region. ${ }^{30}$

Recently, however, Daphon David Ho has agreed with S.A.M. Adshead's conclusion that for Zhao "Xikang was an end in itself, not simply a means to

\footnotetext{
${ }^{27}$ Yang Minghong, "Lun Qingdai Liangshan Yi qu de tusi zhidu yu gaituguiliu," 94; Zeng Zhaolun 曾昭掄, Da Liang Shan Yi qu kao cha ji 大涼山夷區考察記 (Shanghai: Qiu zhen she, 1947), 72-73.

${ }^{28}$ Chang Longqing, Lei Ma E Ping diaocha ji, 14.

${ }^{29}$ Yang Minghong, "Lun Qingdai Liangshan Yi qu de tusi zhidu yu gaituguiliu," 94.

${ }^{30}$ Li Maoyu 李茂郁, "Shi lun Qing mo Chuan bian gaitu guiliu 试论清末川边改土归流," Xizang yanjiu 西藏研究, no. 2 (1984): 5. The view that Kham is a stepping stone to Tibet is certainly evident in later eras, as in Jiang Zemin's aphorism was "A stable Tibet requires a peaceful Kham” (wen Zang bi xian zhi Kang 稳藏必先治康). Wang Huailin 王 怀林, "Guanyu "wen Zang bi xian an Kang" de jingjixue sikao 关于“稳藏必先安康”的 经济学思考" in Kang Zang yanjiu xin silu: wenhua, lishi yu jingji fazhan 康藏研究新思 路: 文化历史与经济发展, ed. Luobu Jiangcun 罗布江村 and Zhao Xinyu 赵心愚 (Beijing: Minzu chubanshe, 2008).
} 
Tibet, and there was the danger that the two policies, Xikang and Tibet, might become rivals rather than complements.”31 Their argument is not that the Zhao brothers did not wish to see Tibet integrated more tightly into the Chinese empire. Rather, the point is that not everything in the reformist agenda for the southwest was geared towards securing control over Tibet. It is a view I agree with, and it fits well with the doubt outlined above as regards how much the British invasion of Tibet was really the sole or most important catalyst for the campaigns in Kham. The reasons for the Khamcentric approach are complex, and belie the fact that more might have been accomplished in Ningyuan. We shall return to this question at various points in later chapters.

In April 1911, Zhao Erfeng was promoted to the post of governor of Sichuan. Adshead suggests that he did not want the job, and there were good reasons to avoid it. ${ }^{32}$ The Qing government's decision to nationalize railways, announced in May, incited widespread fury from stockholders, who, in Sichuan's case, included many people of average means who had been obliged to buy railway shares. ${ }^{33}$ The government offered compensation at market rates, but unfortunately the value of the shares had just crashed due to mismanagement and a fall in the Shanghai stock market. Agitation by the newly formed Railway Protection League (baolu tongzhi hui 保路同志 會) made Sichuan increasingly ungovernable. Zhao Erfeng succeeded in clearing militia units organized by the Railway Protection League out of Chengdu in September, but the fighting escalated in other parts of Sichuan. He was executed by a mob in December 1911.

\footnotetext{
${ }^{31}$ Adshead, Province and Politics in Late Imperial China, 83; Ho, "The Men Who Would Not Be Amban and the One Who Would,” 224.

${ }^{32}$ Adshead, Province and Politics in Late Imperial China, 98.

${ }^{33}$ Lei Yi 雷䝠, "Qing mo "min you" yu "min ying" de ji dou 清末“民有”与“民营”的激斗 ," Nanfang Zhoumo 南方周末, 14-06 2007. Adshead slightly mischaracterizes the railways crisis. Stockholders in Sichuan were a broader community than he suggests, and he does not mention that in some cases they had been obliged to buy stock as a kind of tax. The government was not really being "not unreasonable from a modern perspective" (Adshead, 1984, p.99). There is no reason to suspect that the population of a contemporary Western society in the same position as the Sichuanese in 1911 would be less aggravated. Therefore we cannot relate the citizens' reactions to uniquely Chinese ideas about the state's duty to care for the welfare of the population.
} 
The Republican era

There is a strongly entrenched narrative that says that in the early Republican period, the Chinese state in the Sichuan frontier region more or less collapsed. Sichuanese military leaders who held offices connected with the frontier were frequently accused of ignoring the region and concentrating on the Sichuan basin where the spoils of victory were greater. David Dahpon Ho introduces the Republican period with quotations from the missionary Flora Shelton that give the impression of almost unmitigated chaos: “'cruelty was matched with cruelty', and slicing, quartering, and mutilations were rampant on both sides. 'Heads fell every day, and so many bodies lay in the streets of Batang that at times the dogs feasted'.”34

Many reports suggest that things in Liangshan were even worse from the Chinese perspective. A 1935 article on eastern Liangshan in Sichuan Frontier Quarterly (Chuanbian ji kan 川邊季刊) reported that:

In the Qing period the government paid great attention to border defense, and encouraged people to migrate to and cultivate [frontier territory in Liangshan]. All possible aid and support was provided for settlers. The Yi were afraid of the Han government's authority and did not dare to be unreasonable (wang shi 妄事) or disturb the Han. Thus the arriving farmers were extremely eager (yongyue 踊躍), cultivation advanced quickly, and in turn the places where migrants settled became prosperous. However, after the old regime disintegrated (zhenggang jiezu 政綱解組), the authority of the government lay in ruins [...] The Yi seized the opportunity to come out of their nests, causing mayhem on an immense scale; trespassing, burning, killing and plundering. [...] Han people in the frontiers were killed or captured, or fled. High buildings were reduced to rubble and fertile fields reverted to wastelands full of weeds. ${ }^{35}$

This narrative needs qualifying somewhat. After 1911, Chinese power in central Tibet certainly did collapse. The following year, Yin Changheng尹 昌衡 (1884-1953), the first governor of Sichuan after the revolution, led an

\footnotetext{
${ }^{34}$ Ho, "The Men Who Would Not Be Amban and the One Who Would," 239.

35 ZYDZ, "Diaocha ziliao," Chuanbian jikan 1, no. 3 (1935): 166.
} 
"ill-disciplined" Sichuanese army into the highlands and succeeded in reestablishing Chinese control of Chamdo. ${ }^{36}$

As Eric Teichman, the British consol who was dispatched to the region in 1918 to act as a middleman in negotiations between the Tibetan and Chinese militaries, commented: "the situation began to stabilize itself" in $1914 .{ }^{37}$ Contrary to the impression given in many narratives, Chinese county administrations in the frontier territory appear to have functioned reasonably well in some places in the eastern highlands at this time. Zhu Zengyun 朱增 釷, magistrate of Daofu in 1914 wrote “The turmoil of the borderlands has already calmed down." ${ }^{38}$ He also stated that in his county "the Han are few and the barbarians (yi 夷) many; fortunately they are, by custom, honest and simple folk, and it is not difficult to govern them (bu nan zhi 不難治).”39 When some families ran away from the corvée labour duties to the county government, Zhu was able to use indigenous networks of authority to get them to return. ${ }^{40}$ Zhu also described adjudicating in disputes between locals. Here, at least, Chinese authority was certainly not "in ruins".

At this time, the Sichuan Frontier Finance Department (Chuanbian caizheng ting 川邊財政廳) maintained updated tax registers of gold miners and enforced a supervisory system that involved “mining licenses” (pai 牌) and the organization of miners into "tents” (peng 棚), with “tent heads” responsible for tax payments. ${ }^{41}$ The term “escaped” (toutao 偷逃) appears on many registers next to the names of certain miners, indicating that they had decamped without paying tax. But the numbers of such "escapees” was under ten percent of the total, and local magistrates' ability to keep it so low

\footnotetext{
${ }^{36}$ Teichman, Travels of a Consular Officer, 41.

${ }^{37}$ Ibid., 42-43.

${ }^{38}$ Zhu Zengyun 朱增釷, "Chuanbian zhengxie 川邊政屑 [1914]," in Kangqu Zangzu shehui zhenxi ziliao jiyao (shang), ed. Zhao Xinyu, Qin Heping, and Wang Chuan, 14041.

${ }^{39}$ Ibid., 150.

${ }^{40}$ Ibid., 148.

${ }^{41}$ Mining registers, Chuanbian caizheng ting 川邊財政廳, 1913, (SCDAG, QZH:197, AJH:35).
} 
was a considerable achievement. Nor was such control limited to Han miners; indigenous "tents" and "tent heads" are also mentioned in tax registers and official communications, even in 1918, when as we shall see below, Han state institutions began to weaken. ${ }^{42}$ This ability to tax miners rested on control of at least a part of the indigenous population because, as we shall see in chapter four, tax collectors used the corvée labour that livestock owning households provided. ${ }^{43}$ The indigenes paid other forms of tax to Han authorities as well. In 1917, the highland regional government raised from Kham 20,944 shi 石 of grain (in old Sichuan shi, which were twice the size of the most common shi in Eastern China), and 136,573 Tibetan yuan in livestock tax. ${ }^{44}$ These taxes came from places throughout out Kham, including remote Derge and Sershul, as did the petitions from village heads describing the difficulties households faced meeting grain tax and corvée labour burdens. ${ }^{45}$ Again, this was not an environment in which Han regional state authority had collapsed.

It was in 1918 that the situation really deteriorated from the Chinese point of view. In that year, a skirmish over rights to gather fodder from a mountainside in Chamdo boiled over into a major conflict between the Lhasa government's Tibetan army and the Chinese forces in Kham. The Tibetan army overran Chamdo, Draya, Markam, Gonjo and parts of Bathang and by summer it was approaching Kanze. ${ }^{46}$ At this point the two sides

\footnotetext{
${ }^{42}$ Correspondence between mineral tax commissioners (jinke weiyuan 金科委員) and Director of Bureau of Minerals (jinwu zongju juzhang 金務總局局長), 1919, in Chuanbian caizheng ting 川邊財政廳, (SCDAG, QZH:197, AJH:11).

${ }^{43}$ See also Du Xinwu 杜馨武 report to director of Chuanbian caizheng ting 川邊財政廳, 1919, (SCDAG, QZH:197, AJH:11).

44 “Chuanbian liangshui nianshou gaishu biao 川邊糧稅年收概述表”, 1917, in Sichuan sheng dang'an guan 四川省档案馆 and Sichuan minzu yanjiu suo 四川民族研究所, eds., Jindai Kang qu dang'an ziliao xuanbian 近代康区档案资料选编 (Chengdu: Sichuan daxue chubanshe, 1990, hereafter JKDZ), 99.

${ }^{45}$ See for example Ibid., 123, 157.

${ }^{46}$ Teichman, Travels of a Consular Officer, 57. Of Bathang, a writer styling himself as "Ba Local" wrote in 1943 that "Amid the upheavals after the collapse of the Qing, there were movements to "cleanse the land of the Han and expel the cultivator (xi Han zhu ken 洗漢 逐墾)' [...] the cultivated land reverted to wilderness.”Ba ren 巴人, "Xikang de xin Ba'an 西康的新巴安," Kangdao yuekan 康導月刊 4, no. 4 (1943): 78. However, according to Flora Shelton, an American missionary who lived in Bathang, the town itself never fell to
} 
agreed to a ceasefire, with the provisional boundary being set along roughly the same border that the Qing government established in the eighteenth century between Lhasa controlled-Tibet and the Kham tusi domains that were nominally within Sichuan.

Severe and widespread violence also erupted in Liangshan in late 1917 and 1918. Alan Wininngton wrote: "Matters got much worse from 1918 onwards when the scale and frequency of raid-and counter-raid rapidly increased." ${ }^{47}$ A 1950s survey of the Liangshan region reported that in 1919 "Han were massacred and many forced to leave" parts of eastern Liangshan. ${ }^{48}$ Ethnic cleansing appears to have been particularly severe in the Mabian-Pingshan-Leibo area. ${ }^{49}$ According to the figures in a Sichuan Frontier Quarterly article, Leibo County had been inhabited by 15,256 Han households in $1912 .^{50}$ This increased slightly to 16,837 in 1916 , but from 1918 there was a dramatic fall. Figures show the county losing over fifty percent of its Han households between 1918 and 1920, and the Han population had halved again by 1930. After 1930 it stabilized and began to rise slightly. A chronology of conflict in Mabian indicated that the most serious violence occurred in 1917, 1925 and 1931, with the most significant population decrease apparently occurring in $1917 .{ }^{51}$ Elsewhere in Liangshan in 1917, Yi captured the fortress that Zhao Erxun had built at Zhaojue. ${ }^{52}$ In Xichang, "from 1917 the Yi bandits came out of their lairs and cases of armed robbery increased.” ${ }^{53}$ The large mine at Maha, near

the Tibetans. Flora Beal Shelton, Shelton of Tibet (New York: George H. Doran Company, 1923), 203.

${ }^{47}$ Alan Winnington, The Slaves of the Cool Mountains (London: Serif, 2008 [1959]), 17.

${ }^{48}$ SYSD, 83.

49 ZYDZ, "Diaocha ziliao," Chuanbian jikan 1, no. 1 (1935): 176; Ibid., "Diaocha ziliao," Chuanbian jikan 1, no.2 (1935): 137.

${ }^{50}$ Ibid., "Leibo diaocha," 105-09.

${ }^{51}$ Ibid., "Mabian diaocha 馬邊調查," Chuanbian jikan 1, no. 2 (1935): 26-27, 36.

${ }^{52}$ Zeng Zhaolun, Da Liang Shan Yi qu kao cha ji, 43.

53 Zheng Shaocheng 郑少成 and Yang Zhaoji 楊肇基, "Xichang xian zhi 西昌縣志 [1941]," in Zhongguo Xizang ji Gan Qing Chuan Dian Zang qu fang zhi huibian 中國西 藏及甘青川滇藏區方志匯編, Vol 40, ed. Zhang Yuxin 张羽新 (Beijing: Xueyuan chubanshe, 2003), 422. 
Mianning, was abandoned in 1917 due to attacks by "Yi bandits". ${ }^{54}$ However, although the violence was widespread, it did not occur everywhere where Yi and Han came into contact. One observer wrote that since the start of the Republican period $\mathrm{Yi}$ in Hanyuan "became more passive and Han-ized (Han hua 漢化).”55

The weakening of county level authority from 1917 also occurred in the highlands to the east of the Sichuan basin. Indeed, fighting there might have been somewhat worse than in Kham and Ningshu. In some districts of the eastern highlands depopulation, usually attributed to rampant banditry, was described as "tremendous". 56

Thus, in all the territory on the borders of the Sichuan basin, the most serious declines in population and local state authority occurred not in 1912, but in a period of intense conflict that began in 1917 or 1918 and lasted, depending on the location, between a few years and about a decade. This upsurge in violence occurred at exactly the same time as the Sichuanese military was suffering the effects of the occupation of Sichuan by the Yunnan army. In December 1915 the National Protection Army (hu guo jun 護國軍), formed largely of Cai E’s 蔡鍔 (1882-1916) Yunnan army, entered Sichuan and defeated forces loyal to the would be new emperor Yuan Shikai 袁世凱 (1859-1916). Following this, the chief of the general staff of the National Protection Army, Luo Peijin 羅佩金 (1878-1922) assumed the post of military governor of Sichuan. Luo worked assiduously to replace officials in the Sichuan government with Yunnanese loyal to himself. ${ }^{57}$ Furthermore, Luo sought to concentrate Sichuanese sources of

\footnotetext{
${ }^{54}$ Anonymous (佚名), "Zhili Kangqu yijian shu 治理康区意见书," in Kangqu Zangzu shehui zhenxi ziliao jiyao 康区藏族社会珍稀资料辑要, eds. Zhao Xinyu 赵心愚, Qin heping 秦和平, and Wang Chuan 王川 (Chengdu: Bashu shu she, 2006), 404.

${ }^{55}$ Zeng Zhaolun, Da Liang Shan Yi qu kao cha ji, 62.

${ }^{56}$ C.-Y. Hsiang, "Mountain Economy in Sichuan," Pacific Affairs 14, no. 4 (1941): 452-53. Hsiang's article was based on a just published central government survey of the region.

${ }^{57}$ Yi Bin 易斌, "Shilun min chu Sichuan difang zhuyi de sheng ji guanxi 试论民初四川地 方主义的省际关系," Chongqing shifan daxue xuebao 重庆师范大学学报, no. 2 (2008): 86.
} 
revenue, most notably the salt tax, under the control of his own office. ${ }^{58}$ Rebranded as the National Army, Luo's forces-essentially still the Yunnan army, and often referred to as such-received plentiful funding amounting to 1.2 million yuan per month. ${ }^{59}$ At the same time, funding to Sichuanese military units was cut drastically. Because of this, Sichuanese military units, including the Sichuan Frontier Defence Force owed their staff and soldiers a total of more than two million yuan by April $1917 .{ }^{60}$ The huge budget cuts suffered by the Sichuanese military units stationed in the frontier obviously weakened their capacity to defend against indigenous rebels and deal with bandits. The cuts contributed to the conflict in other ways as well, as we shall see in chapter five.

Weakened though they were, in October 1920 the Sichuanese military units managed to unite and drive the Yunnanese army out of the province. Scholars give mixed reports of Sichuanese civilians' feelings about the occupiers. According to Donald Sutton, for the local population in some places "the Yunnan army yoke often seemed preferable to that of the corrupt and disorderly Sichuan divisions." ${ }^{61}$ Yi Bin, on the other hand argues that "the murder, pillage and rape committed by the Yunnan army aroused the widespread hatred of the Sichuanese population”, ${ }^{62}$ Yi cites a commander in the Yunnan army who reported to a superior: "today the hostility of the Sichuanese is such that even the women and children conspire against us.”63

Following the Sichuan militarists' recovery of the province, state power in parts of the frontier region increased markedly. In 1927, Liu Wenhui became the dominant Chinese authority in the region. At least some of the Chinese settlers in Kham were no more impressed with Liu than Teichman had been with earlier governors. In 1929 a group of settlers petitioned the

\footnotetext{
${ }^{58}$ Ibid.; Wu Yanqin, Qing mo min guo shiqi Chuan Zang guanxi yanjiu, 98.

${ }^{59}$ Yi Bin, "Shilun min chu Sichuan difang zhuyi de sheng ji guanxi," 86.

${ }^{60}$ Wu Yanqin, Qing mo min guo shiqi Chuan Zang guanxi yanjiu, 99.

${ }^{61}$ Donald S. Sutton, Provincial Militarism and the Chinese Republic: The Yunnan Army, 1905-25 (Ann Arbor: The University of Michigan Press, 1980), 230.

${ }^{62}$ Yi Bin, "Shilun min chu Sichuan difang zhuyi de sheng ji guanxi," 88.

63 Ibid.
} 
new Guomindang government in Nanjing to intervene and provide security. They claimed that:

[The Tibetans] have already taken Bathang and Kanze. The armies in those counties repeatedly requested aid from the Sichuan Army, but the Chairman of that Province [Liu Wenhui] replied that the Sichuan situation was critical, and therefore no troops could be spared. The situation in the whole of Xikang is extremely perilous. ${ }^{64}$

In 1939, Liu issued a mea culpa for past inattention to the region. ${ }^{65}$ However, the evidence suggests that Liu Wenhui was reasonably committed to establishing Chinese state power in the region, and reasonably successful at doing so in some places. I have not encountered any other records of major Tibetan advances in 1929, so it is possible that only certain areas of Bathang and Kanze counties had been attacked by Tibetans. Indeed, according to Ren Naiqiang, between 1928 and 1930, Liu’s forces-the "Twenty Fourth Revolutionary Army" in Guomindang nomenclaturerestored Chinese county administrations in Yanjing 鹽井, Daocheng 稻城 and Derong 得榮—all places that were more remote (from the Chinese point of view) than Bathang and Kanze. ${ }^{66}$

Furthermore, at least in some locations, Liu's frontier administration did function effectively at a local level, and was able to depose established power holders. Ren Naiqiang described a prominent frontier community leader in Dawu, who was known as "Barbarian King Ding” (Ding Manwang 丁蠻王). ${ }^{67}$ A Qing period settler, Ding had constructed a personal fortress in Daofu that had allowed him to hold out against a 1911 lama-led uprising, a feat that earned him enough authority for him to be made chief of the local militia (mintuan 民團) when a Han army returned. Ding subverted the militia to his own ends, by exempting its members from corvée duties and charging a fee to join. Because of this he became very rich and possessed of

\footnotetext{
${ }^{64} \mathrm{JKDZ}, 50$.

65 Ibid., 70.

${ }^{66}$ Ren Naiqiang, Xikang tujing: jingyu pian, 155.

${ }^{67}$ Ren Naiqiang, Xikang tujing: minsu pian, 263.
} 
a large amount of authority in the local community. Ren notes that he was asked to adjudicate disputes among the indigenous people, who saw him as a tusi. ${ }^{68}$ In 1928, Ding was the target of two lawsuits, one from a Han merchant and the other from locals who had learned that it was Han government policy to pay for wula corvée labour. Liu’s Xikang Special Administration Committee (Xikang tequ zhengwu weiyuanhui 西康特區政 務委員會) upheld the complaints, and forced Ding out of his position. As this example shows, the formal county administration was able to remove local elites and power holders when it wanted to, which was certainly not the case in many parts of China. ${ }^{69}$

In 1930, the Beri-Targye (Ch. Baili 白利-Dajin 大金) conflict broke out after the tusi of Beri seized the estates of an incarnate lama in his territory, forcing the lama to flee to the Targye monastery. ${ }^{70}$ The forces of Lhasa and Liu Wenhui joined in on opposite sides and the fighting escalated into a war in which the Lhasa army made quick gains. With the help of the Qinghai military leader Ma Bufang 馬步芳 (1903-1975), Liu embarked on a vigorous defense of his position in the region and counter-attack that saw the Lhasa army beaten back to the Yangtze by summer 1932. According to James Leibold, Liu hoped to conquer Lhasa, and it was only the onset of the war between Liu and his relative Liu Xiang that put an end to this hope. ${ }^{71}$ In 1932, there were at least 8,000 Twenty Fourth Army troops in the region. ${ }^{72}$ This was only a tiny fraction of the half a million or so men that Liu Wenhui commanded at the height of his power. ${ }^{73}$ But it was at least double the size of the armies that the Qing sent into Kham in 1905. On the other side, Ren

\footnotetext{
${ }^{68}$ Ibid., 264.

${ }^{69}$ See for example Xin Zhang, Social Transformation in Modern China, pp. 207-210.

70 "Beri" is written as "Pehru” in some sources; I have followed Goldstein.

${ }^{71}$ Leibold, Reconfiguring Chinese Nationalism, 72.

${ }^{72}$ Ren Naiqiang, Xikang tujing: minsu pian, 241.

${ }^{73}$ Shuyun Sun, The Long March: The True History of Communist China's Founding Myth (New York: Doubleday 2006), 146. This figure must be treated as an approximate only, but it makes sense given the numbers of soldiers commanded by key militarists in other regions of China, see Hans J. van de Ven, War and Nationalism in China, 1925-1945 (London: Routledge, 2003), 132.
} 
Naiqiang reported that there were about 10,000 Tibetan fighters at the Dajin monastery. ${ }^{74}$ However, more than half of these were locally raised militia. Liu Wenhui's commitment of 8,000 soldiers to the Kham campaign was no token deployment. Due to logistical difficulties (which we shall examine in chapter four) it was probably about the largest army that he could possibly have fielded in the region without conscripting locals. ${ }^{75}$ Chinese scholars have often portrayed Chinese governors as the passive parties in SinoTibetan wars started by intransigent Tibetan aggressors. But in this case, Wang Haibing has recently argued that neither the Lhasa government nor its military, nor the Targye monastery wanted a war with Liu; a fact that even Liu's own magistrates recognized. ${ }^{76}$ It would be wholly inaccurate to say that Liu Wenhui ignored Kham, did not seek to expand his authority there, or did not successfully do so.

In 1933, Liu was attacked by his relative Liu Xiang and driven out of the Sichuan basin. After his retreat, the rump of his army was stationed entirely in the region that would become Xikang. It was a much smaller force than it had been, although there is some uncertainty about just how small. Sun Shuyun, Cai Yuan and Ni Liangduan all say 20,000 men. ${ }^{77}$ Xiao Bo and Ma Xuanwei do not give a figure, but state that the post-1933 Twenty Fourth Army was reorganized into 12 regiments (tuan 團), which in the modern

\footnotetext{
${ }^{74}$ Ren Naiqiang, Xikang tujing: jingyu pian, 163.

${ }^{75}$ Of course, the Qing force that fought the Qianlong emperor's Jinchuan 金川 wars was much larger. According to Yingcong Dai, the second Jinchuan war (1771-1776) saw the government mobilize 129,500 soldiers and 460,000 military labourers. This war cost more than 61 million taels of silver, more than double what the empire spent on conquering Xinjiang. The question of why Qianlong considered the submission of a small piece of territory around $400 l i$ in length to be worth such an enormous sum is very difficult to answer. For Liu Wenhui to have committed similar resources to Kham at a time when he faced major challenges in Sichuan would have been impossible. Yingcong Dai, "The Qing State, Merchants, and the Military Labor Force in the Jinchuan Campaigns," Late Imperial China 22, no. 2 (2001): 39.

${ }^{76}$ Wang Haibing 王海兵, "1930 niandai de Kang, Qing, Zang zhanzheng -- bianzheng, quanli he difang de shijiao 1930 年代的康、青、藏战争一边政、权利和地方的视角," Anhui shixue 安徽史学, no. 6 (2007): 80.

${ }^{77}$ Sun, The Long March, 146. Ni Liangduan 倪良端, "Liu Wenhui de rensheng licheng 刘 文辉的人生历程," Sichuan tong yi zhan xian 四川统一战线, June 2006, 34. Cai Yuan 蔡 远, "Xikang wang Liu Wenhui 西康王刘文辉," Wen shi jing hua 文史精华, no. 7 (1997): 46.
} 
Chinese military tradition typically contain about 1,000 men, though numbers in any specific case could be higher or lower. ${ }^{78}$ In 1948, A. Doak Barnett wrote that it officially contained 10,000 men, but that "the actual number may be much higher." 79 Thus it is safe to assume that the number of soldiers in the Twenty Fourth Army after 1933 was somewhere between ten and twenty thousand, although it is difficult to narrow down the figure much further. Liu later remarked that the loss of the vast majority of his soldiersmostly due to defection rather than death-constituted the "the greatest grievance of my life." ${ }^{80}$ However, even our minimum of 10,000 was still a substantial force in the highlands. In 1936, the Lhasa government's standing army only contained 5,000 men, plus another 5,000 in irregular militias. ${ }^{81}$

Indeed, the number of soldiers per capita in the regions where the Twenty Fourth Army was deployed (eastern Kham, Yashu and parts of Ningshu) was probably as high as the number of soldiers per capita in northern Henan. ${ }^{82}$ In the latter region, “a reign of terror” unleashed by the army of Feng Yuxiang 馮玉祥 (1882-1948)—the “Christian General”-in 1927 “caused any local challenge to the government's authority to vanish on sight.” ${ }^{83}$ Of course, the topographical difficulties in Liu's Xikang dominion were much greater, but it was undeniably a highly militarized region. Nor

\footnotetext{
${ }^{78}$ Xiao Bo 肖波 and Ma Xuanwei 马宣伟, Sichuan junfa hunzhan 四川军阀混战, 19271934 (Chengdu: Sichuan sheng shehui kexue yuan, 1984), 293.

${ }^{79}$ A. Doak Barnett, China on the Eve of Communist Takeover (New York: Frederick A. Praeger, 1963), 220.

${ }^{80}$ Xiao Bo and Ma Xuanwei, Sichuan junfa hunzhan, 1927-1934, 293.

${ }^{81}$ Goldstein, A History of Modern Tibet, 280.

${ }^{82}$ Feng Yuxiang's army numbered around 310,000 in early 1928, although given the scope of the general's ambitions it is not certain that all were deployed in Henan. Faced with large private militias in the southwest of the province, Feng "failed to keep south-western Henan in his attention”, with the result that the state's authority over local elites was very limited in that region (Zhang, 2000, p.208). The population of Henan in 1931 was reported to be 32.8 million, with about 2.7 million in the south-western counties that slipped out of Feng's field of action. Estimations of the total population of Xikang vary considerably because estimates of the Yi population were little more than wild guesses; however like southwest Henan, those areas were largely outside the operational scope of the provincial regime. 1.5 million is a plausible estimate for the population of the area where Liu’s troops were actually deployed. See: Lou Zuyi 樓祖詒, "Xikang xing 西康 行," Lüxing zazhi 17, no.6 (1943): 9; CKSB, 151.

${ }^{83}$ Zhang, Social Transformation in Modern China, 226.
} 
were Liu's forces crippled or incapacitated by their defeat at the hands of his relative-or if they had been they quickly recovered. Barnett—who had travelled widely in China - thought that they compared favourably to armed forces in some other parts of the country. He noted that Liu's troops were well armed and had plenty of ammunition. "Each squad of sixteen men had fourteen rifles and an automatic weapon; every company has two mortars; every brigade has a special unit of artillery that includes both mortars and guns; and the division had a battalion of artillery." 84

To a significant extent, military strength did translate into state authority in the regions in which it was deployed. In Ningshu, some accounts indicate that Liu's regime was enormously strong in relation to local elites and militias in certain locations. The 1939 Sichuan-Xikang Survey Report reported that:

In the past many private individuals owned guns, but the government took them away. A long time has passed and they still have not been returned, so in effect their weapons have been confiscated. Now the people have no power to buy more, and even if they did, they are afraid that they would be confiscated again. Thus local self defence urgently needs to be revived. ${ }^{85}$

Elsewhere the report noted that:

The custom here has been to prohibit people from owning guns. When the people suffered the ravages [of bandits and Yi], some of them bought guns to defend themselves, but they were arrested by the army and severely punished. [...] People told the same story everywhere we visited [in Ningshu]. ${ }^{86}$

The report was critical of the government's application of power in this case. However, other evidence indicates that the renewed strength of the state in Ningshu did bring greater security to Han settlements there. A 1936 report noted that Xichang had been "calm since the arrival of Commander

\footnotetext{
${ }^{84}$ Barnett, China on the Eve of Communist Takeover, 220-21.

${ }^{85}$ CKSB, 140.

${ }^{86}$ Ibid., 152.
} 
Deng Xiuting 鄧秀廷” in the 1920s, a sentiment that was echoed in postwar reports from the county. ${ }^{87}$ By the end of the 1930s, there was a general sense that peace had broken out in even the areas that had been most affected by what Han observers called the "Yi Scourge" of the late 1910s (a term examined in chapter five). In 1939 Liu Wenhui referred to the "Yi violence” (yi luan 夷亂) as something that had happened in the past. ${ }^{88}$ His assertion was generally supported by reports of the security situation in various parts of Ningshu compiled for Zhang Qun (張拏 ,1889-1990) in the same year. In seven of the 13 listed locations in Xichang, Yuesui and Yanyuan, banditry was described as either only a minor problem or not a problem at all, and in only three locations was it "serious" or "frequent". 89 Reports from Mianning mentioned the "Red bandits" passage through the region years earlier, but not $\mathrm{Yi}$ bandits. The same series of reports summarized the numbers of Yi clans classified as “submitted” (toucheng 投 誠) and “not submitted” (wei toucheng 未投誠) in different counties, which are shown in table one below.

The label "submitted" need not have meant that the Yi group in question obeyed the local Han magistrates in all matters; but equally "not submitted" did not necessarily mean that the group was in active rebellion. Records from the 1940 session of the Xikang Provincial Assembly stated that the "the Yi Scourge has gradually died down (mi ping 敉平) in recent years."90 In a 1947 account, Zeng Zhaolun reported that Xichang's city defences were "unnecessary." 91 By that time, the gaol for Yi in Xichang held only 10

\footnotetext{
${ }^{87}$ ZYDZ, "Diaocha ziliao," Chuanbian jikan 2, no. 1 (1936): 198. 1935 was less calm however, because the "Red Bandits" entered the region and Deng was ordered to send some of his forces after them, leaving Xichang law enforcement understaffed. Zeng Zhaolun, Da Liang Shan Yi qu kao cha ji, 40.

${ }^{88}$ Liu Wenhui 劉文輝, "Ningshu Yi wu wenti zhi jiantao 甯屬夷務問題之檢討," Kangdao yuekan 2, no. 3 (1939).

89 "Ningshu diaocha baogao huibian 寧屬調查報告彙編", 1939, (Beijing daxue library), junshimen 軍事門, 4-10.

${ }^{90}$ Xikang sheng canyihui 西康省參議會, "Linshi canyihui, di yi ci hui huibian 臨時參議會 第一次會匯編," 1940, (SCDAG, QZH:204, AJH:14), section 8 (yi an 議案), p.9a.

${ }^{91}$ Zeng Zhaolun, Da Liang Shan Yi qu kao cha ji, 5.
} 
prisoners; the others having been released. ${ }^{92}$ Zeng wrote: "Since its establishment, the Xichang [Guomindang] Field Headquarters has made great efforts to maintain order and improve commerce. Roads that were seen as dangerous in the past are now open and unobstructed." 93

\begin{tabular}{|l|c|l|}
\hline County & $\begin{array}{l}\text { Number of “submitted” } \\
\text { Yi clans (zhi 支) }\end{array}$ & $\begin{array}{l}\text { Number of “not } \\
\text { submitted” Yi clans }\end{array}$ \\
\hline Yuesui & $28(48)^{94}$ & 36 \\
\hline Mianning & 65 & 13 \\
\hline Xichang & 48 & 105 \\
\hline Huili & 0 & 12 \\
\hline Zhaojue & 2 & 57 \\
\hline Ningnan & 0 & 33 \\
\hline Yanyuan & 67 & 0 \\
\hline Yanbian & 15 & 9 \\
\hline
\end{tabular}

Table one: "Submitted" and "not submitted" Yi clans in Ningshu in 1939. Source: "Ningshu diaocha baogao huibian."

Some amount of Guomindang puffery probably lay behind that claim, but discussion of the difficulties facing the region had changed by the second half of the 1930s. A writer who gave a list of problems holding back private enterprise in Ningshu in the post war period did not even mention conflict or lawlessness. ${ }^{96}$ Accordingly, framings of the “Yi problem” (Yi wu wenti 夷務

${ }^{92}$ Ibid., 36.

${ }^{93}$ Ibid., 5.

${ }^{94}$ There is a discrepancy in the report: the report lists 28 "submitted" Yi clans, but the summary gives 48 .

95 "Ningshu diaocha baogao huibian," junshimen 軍事門, 25-57.

${ }^{96}$ Cheng Yuandeng 程源澄, "Ningshu minying shiye xianzhuang 甯屬民營事業現狀," in Xikang sheng jianshe xie jin hui hui wu nianbao: di san ci 西康省建設協進會會務年報 : 第三次 (Xichang: Xichang Ning yuan yinshua gongsi, 1948), 57-58. 
問題) shifted. From the 1930s, writers began to emphasise that, in the words of Wu Luzhong 吳魯仲, “the Yi problem is not just a simple law and order issue.” ${ }^{97}$ For $\mathrm{Wu}$, the core "problem” was the existence of unassimilated Yi territories (Yi qu 夷區), rather than security per se. Indeed, when it came to security, he pointed out that "the Yi people feel that the Han regions and people are a danger to their existence. From their point of view, the 'Yi problem' is really the 'Han problem' (Han wu wenti 漢務問題).”98 In a 1939 article, Liu Wenhui wrote that "the Han people talk of the Yi Scourge and the Yi people talk of the Han Scourge (Han huan 漢患)”, and other writers also played with the same idea. 99 "In the Yi nests (Yi chao 夷巢) there is a saying 'when the Han come the Yi are finished' (Han dao Yi jue 漢 到夷絕), which is deeply impressed in their minds.” ${ }^{100}$ Estimates of the Yi population tumbled, which possibly also reflected the reality that they were no longer seen as such a great threat to the nearby Han communities. ${ }^{101} \mathrm{~A}$ shift in the focus of discourse away from security may be the result of several factors; but it is likely that an improved security situation was one.

In Kham, Barnett reported that in the territory around and between Ya'an and Kangding Liu's control was "secure and unquestioned."102 Barnett did not rate the provincial government's grip on territory further west very highly. But other sources indicate that, although provincial state authority was far from "unquestioned” west of Kangding, it was still significant to varying degrees. In Drango, by 1945 Chinese county magistrates were said to be handling all law suits — a role they had taken over from lamasalthough they did so in consideration both of modernized Chinese "law" and

\footnotetext{
${ }^{97}$ Wu Luzhong 吳魯仲, "'Yi wu wenti" lungang 『夷務問題』論綱," in Xikang sheng jianshe xie jin hui hui wu nianbao: di san ci, 64.

98 Ibid.

${ }^{99}$ Liu Wenhui, "Ningshu Yi wu wenti zhi jiantao," 4. Wu Liucun 伍柳邨. "Yimin jiancun chuyi -- wei shixian sanhua zhengce er jianyi de yi zhong zhidu 移民建村芻議--為實現 三化政策而建議的一種制度," Bianzheng yuekan 邊政月刊 1, no. 4-8 合刊 (1944): 49.

100 "Ningshu diaocha baogao huibian," 1939, (Beijing daxue library), 農牧門, 56.

101 Zeng Zhaolun, Da Liang Shan Yi qu kao cha ji, 39.

102 Barnett, China on the Eve of Communist Takeover, 221.
} 
what was somewhat disparagingly called local "custom”. ${ }^{103}$ In other places and times Chinese and indigenous authorities seem to have been in equal competition with each other. In 1939 an observer noted that in Nyarong about half of the people were loyal to the (Chinese) county government, the other half presumably being loyal to some form of native ruler. ${ }^{104}$ This, and the fact that only about 300 of the local Tibetan children attended the government schools in the county, was a great problem from the perspective of that official. Yet one could also interpret the existence, 200 kilometers northeast of Dartsedo, of a government school system with a roll of 300 in a population that was half-loyal to a Han magistrate precisely as a sign of the significance of regional government organizations in eastern Kham in the late Republican period.

Sources of State strength

As we have seen, state authority in the frontier crumbled when the Yunnanese occupation of Sichuan resulted in the cessation of Sichuanese funds to the Sichuan Frontier Defence Force. As this indicates, assistance from outside was critical for the Chinese state in the frontier. Zhao Erfeng's campaigning and administration was paid for with subsidies from the central and Sichuan governments that amounted to three million liang of silver annually. ${ }^{105}$ His administration levied taxes in Kham that came to, at most, one tenth of this figure. ${ }^{106}$ Liu Wenhui's administration also drew heavily

\footnotetext{
${ }^{103}$ Yin Ziwen 尹子文, "Luhuo gaikuang 炉霍概况," Kangdao yuekan 2, no. 4 (1945) in Kangqu Zangzu shehui lishi diaocha ziliao jiyao, Zhao Xinyu and Qin Heping eds., (Chengdu: Sichuan minzu chubanshe, 2004), 139.

${ }^{104}$ Xu Wenchao 许文超, "Zhanhua shangzhanqu diaocha ji 瞻化上瞻区调查记," Kangdao yuekan 1, no. 4 (1939). In Zhao Xinyu and Qin Heping, eds., Kangqu Zangzu shehui lishi diaocha ziliao jiyao, 192.

${ }^{105}$ Adshead, Province and Politics in Late Imperial China, 82.

${ }^{106}$ Weng Zhizang 翁之藏, Xikang shi kuang 西康實況 (Shanghai: Min zhi shu ju, 1930), 168; Yang Jianwu 杨健吾, "Minguo shiqi kangqu de jinrong caizheng 民国时期康区的 金融财政," Xizang yanjiu 西藏研究, no. 3 (2006): 105.
} 
on support from outside Xikang. In 1939, legal tax income (i.e. excluding most opium related income) from Kham, Ningshu and Yashu came to about 1.4 million yuan. ${ }^{107}$ Despite the famous tensions between Liu Wenhui and the central government, Liu was still able squeeze 2.8 million yuan from the national government that year; half of it listed as "regular/permanent" (jingchang 經常), while the other half was “temporary” (linshi 臨時). ${ }^{108}$ An additional 360,000 yuan came from the Sichuan government, though this subsidy was stopped in $1942 .{ }^{109}$ It is difficult to compare the finances of Zhao Erfeng and Liu Wenhui. Liu received a smaller subsidy in relation to his tax revenue, but a large portion of that tax revenue was drawn from Ningshu and Yashu, which had not been part of Zhao's Kham administration. However, a significant amount of Liu's expenditure was also directed toward Ningshu and Yashu. As we shall see in chapter three, there was a definite bias toward Kham in provincial government spending, although to what extent Ningshu and Yashu subsidized Kham is difficult to judge.

In any case, one significant source of Liu Wenhui's income was mostly not recorded in his administration's official budgets: opium. Some revenue from opium did make it into government accounts, that which was called “prohibition income” (jin yan shouru 禁煙收入), which came from sales of licences to the county opium shops and opium users as part of the national anti-drug campaign. ${ }^{110}$ However, as Peng Dixian notes, the anti-opium regulations in Xikang were just “empty words", and the government profited hugely from the unregistered-hence illegal—opium trade. ${ }^{111}$ The military took some opium directly from farmers as tax; they bought some of

\footnotetext{
${ }^{107}$ CKSB, 397-98.

108 Ibid.

${ }^{109}$ Ibid.; Peng Dixian 彭迪先 et al., eds., Liu Wenhui shihua 刘文辉史话 (Chengdu: Sichuan daxue chubanshe,1990), 146.

${ }^{110}$ Xikang sheng canyihui 西康省參議會, "Linshi canyihui, di yi ci hui huibian 臨時參議 會第一次會匯編," 1940, (SCDAG, QZH:204, AJH:14), section 9, p.14. See also Alan Baumler, The Chinese and Opium under the Republic (Albany: State University of New York Press, 2007), 226-27.

${ }^{111}$ Peng Dixian et al., eds., Liu Wenhui shihua, 146.
} 
it; and the remainder was marketed by private merchants, who of course paid tariffs on it. ${ }^{112}$

Arguably, opium should count as another form of assistance that the national government granted Liu Wenhui, because it was the Guomindang war on drugs that drove large scale opium production for export into Xikang. Communities in the highlands grew opium for their own consumption throughout the first half of the twentieth century. However, there were only two periods in which they exported a significant volume of opium to other parts of China. Both periods of export corresponded with government opium suppression campaigns that successfully slashed production in the Sichuan basin. As Alan Baumler has pointed out, "when the lowlands were producing opium in bulk, exporting from remote areas was not worthwhile.” 113 Highland opium was only competitive in major markets like Chengdu and Chongqing if the territory around those centres was unable to produce it. By eradicating opium production from the lowlands, the central government gifted the highland state a potential source of revenue that was possibly more valuable than its subsidies.

The first period of opium suppression in the Sichuan basin occurred at the end of the Qing dynasty, between 1906 and 1911. This anti-opium campaign was so successful that Alexander Hosie reported seeing no poppy plants at all during his travels through the Sichuan basin in 1910 and 1911. ${ }^{114}$ According to the missionary Samuel Pollard, this resulted in opium producers relocating to the Liangshan Yi territories where they made "large payments to the chiefs" in return for permission to cultivate the poppy. ${ }^{115}$

\footnotetext{
${ }^{112}$ See Zhang Weijiong 张为昫, "Xikang jian sheng ji Liu Wenhui de tongzhi 西康建省及 刘文辉的统治," in Sichuan wenshi ziliao xuanji, di shiliu ji 四川文史资料选辑, 第十 六辑 (Chengdu: Zhongguo renmin zhengzhi xieshang huiyi Sichuan shengweiyuanhui 中 国人民政治协商会议四川省委员会, Sichuan sheng sheng zhi bianji weiyuanhui 四川省 省志编辑委员会, 1965), 47-48.

${ }^{113}$ Baumler, The Chinese and Opium under the Republic 218.

${ }^{114}$ Alexander Hosie, On the Trail of the Opium Poppy: A Narrative of Travel in the Chief Opium-Producing Provinces of China, 2 vols., vol. 2 (London: George Philip \& Son, 1914), 21. See also S. A. M. Adshead, "The Opium Trade in Sichuan, 1881 to 1911," Journal of Southeast Asian History 7, no. 2 (1966): 93-99.

${ }^{115}$ Pollard, In Unknown China, 238.
} 
There is no record, however, that the late Qing frontier regime capitalized on this sudden arrival of a commercially viable industry in the highlands.

After 1911, large scale poppy cultivation returned to the Sichuan basin very quickly and apparently at the expense of opium exports from the $\mathrm{Yi}$ territory. According to Baumler, opium exports from the highlands only resumed after around 1936. ${ }^{116}$ By that year, the Guomindang anti-opium campaign had replicated the success of the late Qing efforts, and it became worthwhile again for merchants and soldiers to start buying opium from the Xikang indigenes. The Sichuan-Xikang Survey Report also reported that it was "when the price of opium was high in the interior" that "the Yi seized the opportunity to grow poppies.”" ${ }^{117}$ That report guessed that in 1939 about 5 million liang of opium was grown in Ningshu annually and 300,000 liang in Yashu. ${ }^{118}$ According to this source, the part of Kham that was in Xikang (and thus controlled by Liu Wenhui) did not produce any significant amount in that year. ${ }^{119}$ Certain Tibetan areas in northern Sichuan, like Songpan, grew a very large amount of opium from the mid 1930s, but these places were not part of Xikang province or controlled by Liu Wenhui. ${ }^{120}$ Cultivation spread from these places into the parts of Kham that were controlled by Liu Wenhui perhaps a year or two after 1939, when prices were even higher in the Sichuan basin. ${ }^{121}$ According to one estimate, in 1942 800,000 liang 兩 was grown around Danba and sent through Kangding. ${ }^{122}$ Finally, in 1940, Liu Wenhui is alleged to have struck a deal

\footnotetext{
${ }^{116}$ Baumler, The Chinese and Opium under the Republic 218.

${ }^{117}$ CKSB, 171.

${ }^{118}$ Ibid., 406.

${ }^{119}$ Ibid.

${ }^{120}$ See Liu Jun 刘君, "Jindai Sichuan Zangqu yapian maoyi jiqi shehui weihai 近代四川藏 区鸦片贸易及其社会危害," Zhongguo Zangxue 中国藏学, no. 3 (2002).

${ }^{121}$ Liu Jianbang 刘建邦, "Qing mo Min(guo) chu Xikang dongbu ge xian kenwu gaikuang 清末民（国）初西康东部各县辱务概况," in Ganzi Zhou wenshi ziliao, no. 14 甘孜州 文史资料，第十四辑, ed. Zhongguo renmin zhengzhi xieshang huiyi Ganzi Zangzu zizhizhou weiyuanhui 中国人民政治协商会议甘孜藏族自治州委员会 (Kangding: Kangding xian yinshua chang, 1996), 100.

${ }^{122}$ Ibid.
} 
with Long Yun 龍雲 (1884-1962), the military governor of Yunnan, allowing for Yunnanese opium to be trafficked through Xikang to Chengdu. ${ }^{123}$ As cultivation in Xikang expanded however, trade with Yunnan declined, from a peak of about 500,000 liang. ${ }^{124}$

Unlike Zhao Erfeng, Liu Wenhui certainly had no scruples about deriving income from the opium crop. Some historians rank it as his government's largest source of revenue. ${ }^{125}$ It is difficult to assess this claim without knowing more about the production and distribution system and about the final market value of the product. Good price data is surprisingly rare. A few sources quote a figure of three to four yuan per liang in Chengdu in the Liu Wenhui era. ${ }^{126}$ But they do not say when this was, and prices must have changed substantially due to hyperinflation and opium prohibition. Other sources are vague about currency units and places. ${ }^{127} 3.5$ yuan per liang in 1939 would put the total value of the product that came from or through Xikang that year at least 21 million yuan. Liu Wenhui's tariffs on Yunnanese opium were apparently 15 percent; if the rate of profit on the opium the military bought or appropriated from farmers was the same, then provincial government income from opium would have been at least as much as the subsidy from the central government. ${ }^{128}$ Another way of looking at Xikang's opium revenue is to consider that Communist Party surveyors estimated that there were about 100,000 guns in Yi hands in Liangshan in 1950. ${ }^{129}$ Most must have been bought with opium because the

\footnotetext{
${ }^{123}$ Zhang Weijiong, "Xikang jian sheng ji Liu Wenhui de tongzhi," 47.

${ }^{124}$ Ibid.

${ }^{125}$ Cai Yuan, "Xikang wang Liu Wenhui," 46; Barnett, China on the Eve of Communist Takeover, 227.

${ }^{126}$ Zhang Weijiong, "Xikang jian sheng ji Liu Wenhui de tongzhi," 47; Peng Dixian et al., eds., Liu Wenhui shihua, 146.

${ }^{127}$ Zhou Yongming, Anti-Drug Crusades in Twentieth Century China: Nationalism, History, and State Building (Lanham: Rowman and Littlefield Publishers, 1999), 152. Zhou quotes a source that states that one liang of opium could be exchanged for six liang of silver in 1940. This seems a little too high, and in any case, appears to be the price given to the Yi cultivators, not the final sale price.

${ }^{128}$ Zhang Weijiong, "Xikang jian sheng ji Liu Wenhui de tongzhi," 47.

${ }^{129}$ Zhou Yongming, Anti-Drug Crusades in Twentieth Century China, 152.
} 
Yi had little else to sell (some could have been captured). This hardly represented the total opium trade, because the Yi also acquired other things, such as silver, and ordinary products such as cloth and salt. If the Xikang state's dividend from the opium-firearms trade equalled only ten percent of the value of the guns going into Liangshan, this would have been enough to arm 10,000 soldiers, or at least half of the Twenty Fourth Army after 1933.

\section{Conclusion}

This chapter has given an overview of the rise and fall and rise of the Chinese state in the highlands of west and southwest of Sichuan in the first half of the twentieth century. It has been common to highlight the failures of this state-making endeavour, as we saw in the quotations given at the beginning of our discussion of the Republican era. Such sentiment is also reflected in current histories of this period. Elliot Sperling writes: "The legacy that Zhao would have liked to have left behind in K’am [Kham] [...] was unrealizable during and after his lifetime, due to the unwillingness of both Chinese and Tibetans to take part in it."130 Hsiao-ting Lin has been similarly negative. ${ }^{131}$ Such assessment is valid if we judge the frontier state by its own ambitions. It did not control large areas of the territory it claimed. Nonetheless, the Chinese governors of the frontier did succeed in constructing a reasonably robust state in parts of Ningshu and the eastern counties of Kham.

The Sichuan frontier largely falls into the mega-region that James C. Scott and other scholars call "Zomia” ("zo" means "remote” or "of the hills" in many Tibeto-Burmese languages, “mi” means "people). ${ }^{132}$ In Scott’s analysis, the terrain of Zomia made it inimical to state-building and permanent conquest by lowland states before the development of things

\footnotetext{
${ }^{130}$ Elliot Sperling, "The Chinese Venture in K'am," 32.

${ }^{131}$ Lin, Tibet and Nationalist China's Frontier, 68.

132 James C. Scott, The Art of Not Being Governed: An Anarchist History of Upland Southeast Asia (New Haven: Yale University Press, 2009).
} 
such as "all-weather roads, bridges, railroads, airplanes, modern weapons, telegraph, telephone, and now modern information technologies including global positioning systems.”133 That Chinese governors managed to develop any kind of authority at all in the region-without most of those things and during a time in which China was beset by internal conflict and the Japanese invasion-is, in light of Scott's argument, quite remarkable. The last time Han local authority and settlements had been established in this region, in the wake of the eighteenth century Jinchuan wars, it had required more silver than the conquest of Xinjiang to solidify control over a territory smaller than that dominated by Liu Wenhui. ${ }^{134}$ Therefore, it would be more pertinent to focus on the successes of the early twentieth century Chinese colonization efforts, rather than their failures.

As we have seen, those successes were due in no small part to assistance from the rest of China, which came in a couple of forms. Firstly, and most directly, such assistance took the form of cash subsidies. It also came in the form of a drugs policy that sent opium cultivation into the highlands and the welcoming arms of Liu's regime. Other forms of income were important to the highland state (we shall examine some of them in chapter three), but these two were the most significant. However, the establishment and survival of a frontier state was also achieved through adaptation to local challenges, pre-existing institutions and the local environment. As a result, the regional and local Han-dominated governments that developed in this region were not simply transplanted copies of some kind of prototypical Chinese order. On the contrary, its character was thoroughly shaped by local political and economic contexts. In chapter two we shall examine the original Qing vision for the region; and in chapters four and five we shall see how, despite some strong ideological continuity, various factors inherent in the local context led to moves away from this vision in the Republican period.

\footnotetext{
133 Ibid., 11.

${ }^{134}$ Peng Zhiyan 彭陟炎. "Shi lun Qianlong pingding Jinchuan zhi yingxiang 试论乾隆评 定金川之影响." Xizang yanjiu 西藏研究, no. 1 (2003): 4.
} 
Chapter Two: Development Visions and Policy, 1905-1911.

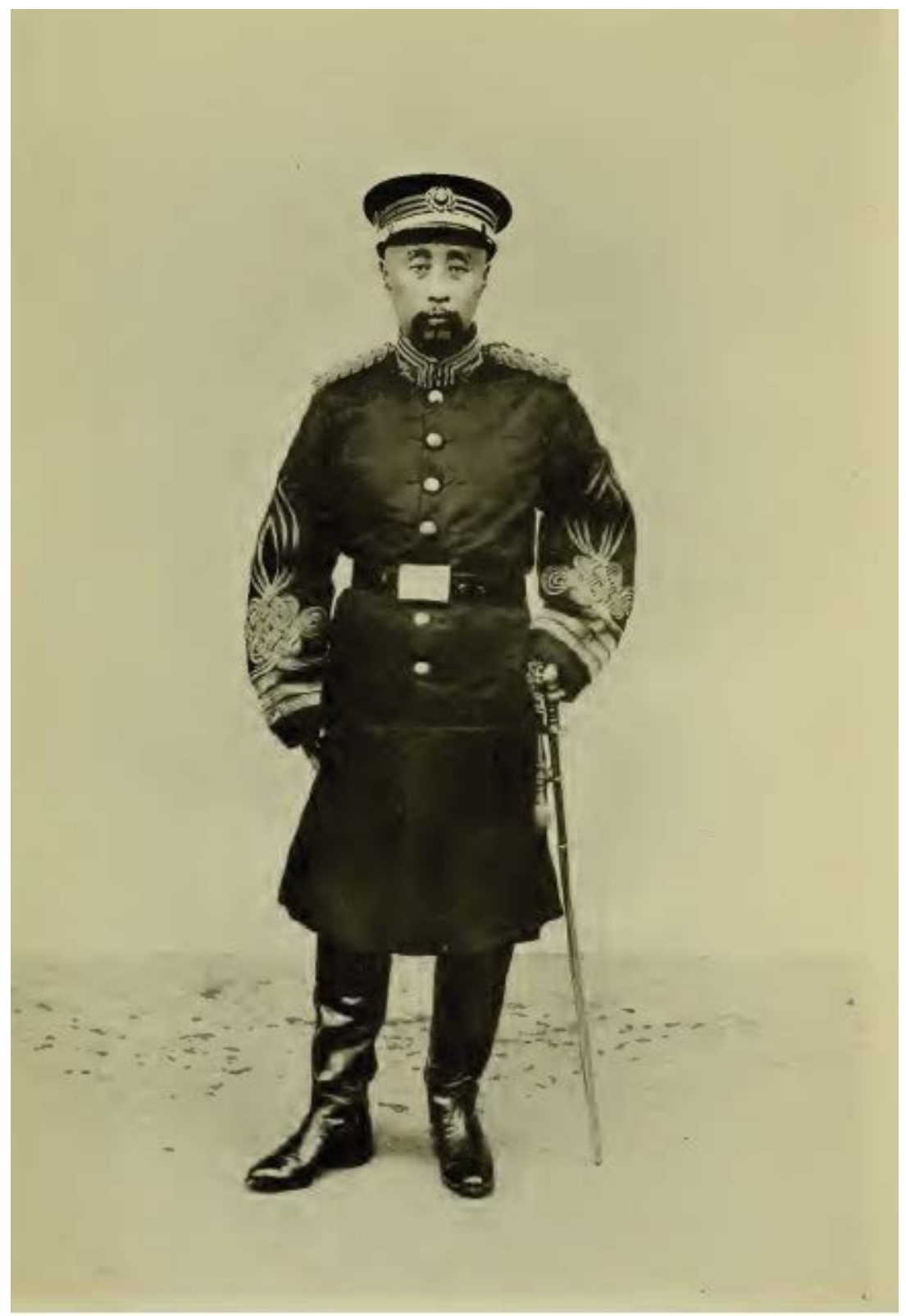

Zhao Erfeng. Source: Earnest Henry Wilson, A Naturalist in Western China. ${ }^{1}$

This chapter concentrates on the vision and policy of the Qing rulers of the Sichuan frontier in the last decade of the dynasty. As the previous chapter

\footnotetext{
${ }^{1}$ Ernest Henry Wilson, A Naturalist in Western China with Vasculum, Camera, and Gun: being some Account of Eleven Years' Travel, Exploration, and Observation in the more Remote Parts of the Flowery Kingdom, vol. 2, (London: Methuen \& Co. Ltd., 1913), 207.
} 
noted, the Zhao brothers were particularly Kham-centric in their planning and use of resources, so this chapter focuses on Kham, rather than Ningyuan. Elliot Sperling has commented that "It can safely be said that Zhao Erfeng's aim was to sinicize K'am as far as possible.”2 At the most general level, Sperling's view is correct, but such a judgment implies that there is only one way of being Han Chinese. What kind of Chinese society did Zhao Erfeng hope to create in the highlands, and why? This chapter makes three broad arguments about his administration's vision and policy. Firstly, it drew overwhelmingly on certain Qing precedents of frontier governance and was not as innovative or influenced by Western models of colonial control as some historians have assumed. Secondly, its developmental agenda prioritized grain production above mining or other extractive industries, for ideological reasons as much as practical ones. Thirdly, Zhao's plan for Kham was based on a sounder understanding of Kham's environment than some Republican period critics believed it was. Those critics perhaps paid too much attention to things that Zhao wrote in order to attract funding or settlers, and misinterpreted the intentions of some of his policies. However, the late Qing administration's efforts to gather and disseminate more knowledge about highland environments were relatively lacklustre and narrowly focused compared with the efforts of late Qing administrations in Xinjiang.

The Zhao brothers have been cast as modernizers by Chinese and nonChinese scholarship alike. Adshead argues that “At a time when the Qing state was widely regarded as weak, traditional and non-Chinese, the Zhao brothers displayed it as strong, modern and nationalist.”3 William Coleman writes: “Characteristic institutions of modernity appear throughout Zhao's actions in Kham. Zhao Erfeng's actions in Kham were driven by an ideology of imperialism, and this ideology was fundamentally modern.” Ma Jinglin explains Zhao's actions in Kham as both a response to the

\footnotetext{
${ }^{2}$ Elliot Sperling, "The Chinese Venture in K'am," 20.

${ }^{3}$ S. A. M. Adshead, Province and Politics in Late Imperial China, 84.

${ }^{4}$ William M. Coleman, "The Uprising at Batang," 50.
} 
British threat to Tibet and product of the modernizing effort that came in the wake of the Boxer catastrophy (known as the 'New Policies', Qing mo xin zheng 清末新政). ${ }^{5}$

All historians working outside China have highlighted the references that Zhao Erfeng made to Western and Japanese imperialism; arguably this apparent influence on Zhao is one of the reasons for the view that he was a modernizer. ${ }^{6}$ Historians working in China have not noted Western imperialism as an inspiration for his policy. It is unclear whether this is because it would be politically incorrect to point out the similarities between Western empire and Chinese rule in Tibet, or because they believe thatwhether or not such similarities exist-Western imperialism was actually not much of an influence on Zhao (a point that I will argue below).

In contrast to most historians, Wang Xiuyu has argued that the ideology of the frontier administration was somewhat more eclectic than an amalgam of nationalism, imperialism and modernism:

Qing officials did not merely imitate the other colonizers nor rehearse a derivative colonial discourse; they also drew upon an older Chinese repertoire of frontier statecraft, combining colonialism, dynasticism, and Confucianism with some threads of modernization, at the same time seeking a symbiosis between bureaucratic and merchant management. ${ }^{7}$

Louis Sigel also suggests that, in addition to Western imperialism, the jingshi 經世 ('statecraft') school of school of Confucianism was an important influence on Zhao Erfeng. ${ }^{8}$ Thus, we have Zhao the modernizer, the nationalist, the Confucian, and the student of Western imperialism. Was he all these in equal measure? If so, how did the different components interact with each other?

\footnotetext{
${ }^{5}$ Ma Jinglin, Qing mo Chuanbian Zang qu gaitu-guiliu kao, chapters 4-6.

${ }^{6}$ David Dahpon Ho, "The Men Who Would Not Be Amban and the One Who Would," 224; Coleman, "The Uprising at Batang," 50; Sperling, "The Chinese Venture in K'am," 23; Roger V. Des Forges, Hsi-liang and the Chinese National Revolution, 82; Louis T. Sigel, "Ch'ing Tibetan Policy (1906-1910)," in Papers on Asia, vol.20 (Cambridge, Mass.: East Asian Research Center, Harvard University, 1966), 191.

${ }^{7}$ Wang Xiuyu, "China's Last Imperial Frontier," 349. What Wang means by “dynasticism” is a little unclear.

${ }^{8}$ Sigel, "Ch'ing Tibetan Policy," 191.
} 
Western imperialism was probably the least important influence, if it was influential at all. There were similarities between the Chinese frontier administration and Western and Japanese colonial regimes. But it is very difficult to make the case that Zhao adopted any particular policy because of what he had learned through studying foreign imperialism. The sum total of his references to foreign imperialism amount only to the following lines among all the memorials he wrote while in the frontier:

Those countries that have opened up distant wastelands, as Britain has in Australia, France in Madagascar, America in the Philippines and Japan in Hokkaido, have all first established hostels for migrants, and attracted them by offering benefits. ${ }^{9}$

And:

In Poland, India and Taiwan, the governments of, respectively, Russia, Britain and Japan have implemented policies to teach their own language and culture to the locals with the aim of assimilating (tonghua 同化) them. This proves the effectiveness of such policy. ${ }^{10}$

The brevity and sparseness of Zhao's references to Western imperialism suggest it was not a major influence. So too does their content. Hokkaido and Australia are, at least, examples of successful settler societies. It is almost inconceivable, however, that Zhao's settlement policy for Kham had been inspired by study of American policy for the Philippines (and not very likely any French policy for Madagascar). Why did Zhao mention these examples, if they were not models that he genuinely aspired to emulate? The clue is in the second quote: "This proves the effectiveness of such policy." In all probability, these references were rhetorical devices aimed at boosting the strength of his argument. The claim that his policy was similar to that of the great powers implied that it was the right course of action for a country that aspired to be a great power. As chapter one suggested, and we shall see again below, there was no unanimity within officialdom on the desirability

\footnotetext{
${ }^{9}$ Zhao Erfeng and Wu Fengpei, Zhao Erfeng Chuan bian zou du, 48.

${ }^{10} \mathrm{QCBD}, 247$.
} 
and feasibility of Zhao's program. There were doubters at most levels of government. Yet Zhao was asking the court to make an enormous commitment. As David Dahpon Ho argues, by supporting his campaigns "the Qing court was willing to flirt with fiscal disaster." 11 In such circumstances, Zhao must have felt some pressure to prove that his approach to the frontier, which cost 12 times as much annually as Xiliang's, was a sound investment. ${ }^{12}$ Comparisons with the tactics of Western powers should be interpreted in light of this, not as explanations of the actual origins of his ideas.

This is not to argue that Zhao had no intellectual interest in foreign methods of frontier governance. But, ultimately, they were not a major influence on his policies. Similarly, his brother Erxun had shown an interest in British local government while he experimented with administrative reform during his brief tenure as governor of Shanxi in 1902 and 1903. ${ }^{13}$ However, as Roger Thompson demonstrates, even though Erxun's reform proposals referred to "Western institutions, [they] stressed the importance of current practice and statecraft theory”. ${ }^{14}$ Thompson contrasts Erxun's approach with that of Yuan Shikai, whose reforms were more clearly shaped by Western and Japanese models. The Zhao brothers were curious about the West, but the key sources of influence on them lay within Chinese tradition.

As for Zhao the modernizer, there were aspects of his rule that could indeed be described as modernizing, but it is easy to exaggerate them and important to clarify what one means by “modernization”. Scholarship in the 2000s has greatly narrowed the developmental gap that was once supposed to exist in all or most fields between post-Renaissance Europe and China. Peter Perdue positions the Qing Empire as the peer of other large Eurasian early modern states like the Russian and Ottoman Empires, and Kenneth Pomeranz has famously argued that Britain had no advantage over the most

\footnotetext{
${ }^{11}$ David Dahpon Ho, "The Men Who Would Not Be Amban and the One Who Would," 222.

${ }^{12}$ Ibid.

${ }^{13}$ Roger R. Thompson, China's Local Councils in the Age of Constitutional Reform, 18981911 (Cambridge, Mass.: Council on East Asian Studies, Harvard University, 1995), 28.

${ }^{14}$ Ibid., 35.
} 
advanced parts of China until about $1800 .{ }^{15}$ Perdue further labels the eighteenth century Qing government's monitoring of the agricultural economy as "precociously modern”. ${ }^{16}$

Zhao Erfeng could fairly be considered a modernizer to the extent that the well-established precedents that his policies drew on can themselves be considered modern, or at least 'early modern'. But his policies rarely went beyond long-standing Qing traditions. The Qing emperors are famous for being content to govern the different component parts of their empire through indigenous leaders and institutions. But when such leaders acted contrary to what was seen as the imperial interest, emperors rarely hesitated to use massive amounts of force to remove them, as the Zunghars and the Jinchuan chieftains found out. Removal of the tusi from Kham was not an unprecedented response to the anti-Qing violence that broke out in the region in 1905. Zhao Erfeng moved to restrict the power of lamas, but this was nothing new either. In the eighteenth century, Nian Gengyao 年美堯 (1679-1726) established limitations on the numbers of lamas at monasteries in Qinghai, forced them to register with the government and undergo inspections twice a year. ${ }^{17}$ One scholar makes much of Zhao's decision to pay serfs for the labour and animals they provided for the transport of his forces. ${ }^{18}$ In fact, payment for this kind of labour was a well established part of Qing engagement with the Tibetan lands, though Republican period writers were also mostly ignorant of this (issues that are explored further in chapter four). ${ }^{19}$ Zhao hired a Japanese agronomist and an American trained Chinese geologist, but the use of foreign technical and scientific advice was

\footnotetext{
${ }^{15}$ Peter C. Perdue, China Marches West: The Qing Conquest of Central Eurasia (Cambridge, Mass.: Harvard University Press, 2005), 127; Kenneth Pomeranz, The Great Divergence: China, Europe, and the Making of the Modern World Economy (Princeton, N.J.: Princeton University Press, 2000).

${ }^{16}$ Perdue, China Marches West, 358.

${ }^{17}$ Perdue, "Empire and Nation in Comparative Perspective: Frontier Administration in Eighteenth-Century China," Journal of Early Modern History 5, no. 4 (2001): 292.

${ }^{18}$ Coleman, "The Uprising at Batang," 50.

${ }^{19}$ See Chen Yishi 陈一石, "Chuanbian Zangqu jiaotong wula chaiyao kaosuo 川边藏区交 通乌拉差徭考索," Xizang yanjiu 西藏研究, no. 1 (1984): 52-53.
} 
hardly outside the bounds of Qing tradition either. ${ }^{20}$ There was no substantial attempt to spread the Chinese language among Tibetans until Zhao established schools in Kham, but other non-Han communities in the southwest had attended Chinese language schools since the Ming dynasty. ${ }^{21}$ Zhao laid greater stress on schooling than most of his predecessors did, but it was a difference of degree rather than nature.

Zhao Erfeng was not much of a modernist. He was more of a late imperial conservative, who drew eclectically on what he no doubt viewed as the tried and true policies from the better days of the early and high Qing periods. "Neo-Conservative" would not be too far-fetched. He was radical in the scope his vision and in the energy with which he pursued it, but the content of that vision was not innovative. Des Forges comments that Zhao wanted to turn Kham into another Manchuria. ${ }^{22}$ The following section outlines Zhao's settlement policy and then shows how it was in fact more similar to early and high Qing frontier settlement than it was to the system in Manchuria in the 1900s.

\section{The Settlement Policy of the Zhao Regime}

Having put down the revolt at Bathang, which he renamed Ba’an 巴安; “Ba Peace”, Zhao Erfeng and Xiliang promulgated in December 1906 what became one of the key legal documents in the new Sichuan Frontier administration: the "Bathang Reconstruction Articles" (Batang shanhou

\footnotetext{
${ }^{20}$ See Joanna Waley-Cohen, "China and Western Technology in the Eighteenth Century," American Historical Review 98, no. 5 (1993).

${ }^{21}$ John E. Herman, Amid the Clouds and Mist: China's Colonization of Guizhou, 12001700 (Cambridge (Mass.): Harvard University Press, 2007), 143. Herman describes education provided to non-Han people in Guizhou in rather negative terms: "education offered the non-Han people most assuredly consisted of little more than language instruction sprinkled with moral tomes” (p. 143). This is a fairly good summation of the kind of education that Zhao's government established in Kham; though language instruction by itself was no small undertaking, whether in Ming period Guizhou, or twentieth century Kham

${ }^{22}$ Des Forges, Hsi-liang and the Chinese National Revolution, 82.
} 
zhangcheng 巴塘善后章程). ${ }^{23}$ These regulations provided for a complete restructuring of Bathang's political, economic and social life. Republican period writers often argued that they established state ownership (literally, “national ownership”, guo you 國有) over all land in the whole Bathang (or even Kham) administrative region. ${ }^{24}$ This notion has been perpetuated in recent Chinese scholarship, though today's scholars prefer the more historically appropriate term guan you 官有, “government ownership” to guo you, which was not common in the Qing documents. ${ }^{25}$ These claims appear to be rooted in the account written by Zhao's successor as Warden of the Marches, Fu Songmu 傅嵪炑 (1869-1929). ${ }^{26}$ The articles themselves proclaim that land in the whole Bathang region was "the domain of the Emperor” (quan jing jie da huangshang ditu 全境皆大皇上地土). This should be treated as an assertion of sovereignty rather than state ownership. As far as the latter is concerned, the regulations only stated that all wasteland (huang 荒) was guan you. Hence, there was no "nationalization” of land that was obviously worked by the indigenes. Those who worked land for monasteries, for example, were ordered to call themselves the “tenants of the monastery” (miao zhi dian hu 廟之佃戶) and explicitly forbidden from identifying themselves as "subjects/people of the monastery/lamas” (lama zhi baixing 喇嘛之百姓). They did not become "tenants of the state", as farmers who cultivated land that was huang in 1906 did (as we shall see below).

Before the arrival of Zhao Erfeng, Xiliang had initiated a modest pilot land cultivation scheme at Bathang. The framework of this program had allowed for both “state cultivation” (guan ken 官墾), and “private

\footnotetext{
${ }^{23}$ The regulations may be found in $Q C B D, 1: 95-103$. The Chinese-Manchu administrative and legal systems were to be transplanted to the new county, along with key laws like the hairstyle regulations. Various local customs including burial rites were outlawed, and clothing styles regulated.

${ }^{24}$ Wu Wenhui 吴文暉 and Zhu Jianhua 朱鑒華, "Xikang tudi wenti 西康土地問題," Bianzheng gonglun 邊政公論 3, no. 6 (1944): 20.

${ }^{25}$ Deng Qiancheng 邓前程, "Lun Qing mo Chuanbian kenzhi 论清末川边垦殖," Sixiang zhanxian 思想战线, no. 3 (2007): 56.

${ }^{26}$ Fu Songmu, Xikang jiansheng ji, 2: 8, 10.
} 
cultivation” (min ken 民墾). ${ }^{27}$ Zhao Erfeng’ regulations abandoned the latter. Land categorized as wasteland could only be cultivated via the government's own program, and could not be transferred to full private ownership afterwards. Zhao wrote:

In Bathang and Xiangcheng 鄉城 there is much huang land. From 1906, recruiting settlers to cultivate this land is the prerogative of the government. No man, be he Han or Barbarian (man 蠻), priest or layman may privately cultivate this land of his own initiative. Those who wish to cultivate huang land, be they Han or Barbarian, priests or laymen, must obtain a licence from the government before doing so [...] Henceforth, they shall be tenants of the state (guandian 官佃), with permanent rights to cultivate the land. ${ }^{28}$

The Articles did not specify how much such licenses would cost, but one Republican era source gives a figure of 12.5 Tibetan yuan (Zangyang yuan 藏洋元). ${ }^{29}$ Migrants usually signed a contract with the government which spelled out how cultivation was to be conducted. ${ }^{30}$

Having made such contracts, farmers were allowed to "freely cultivate the [waste]land to the limit of their own strength.”31 Ren Naiqiang's short biography of a husband and wife who were assigned to Yanjing 鹽井 confirms that this was the way it worked in reality as well, at least some of the time. $^{32}$ After the government loans had been paid off, the local commissioner in charge of cultivation was to survey the land that the settler had managed to farm. ${ }^{33}$ At no charge, the government granted titles (di qi 地

\footnotetext{
${ }^{27}$ QCBD, 1: 9.

${ }^{28}$ Ibid., 97-98.

${ }^{29}$ Liu Hengru et al., "Shicha Dao Lu De Bai Zhan Ya Jiang qi xian baogaoshu," 50.

${ }^{30}$ Zhao Yuntian 赵云田, "Qing mo Chuan bian gaige xintan 清末川边改革新探," Zhongguo Zangxue 中国藏学, no. 3 (2002): 44.

${ }^{31}$ Zou Lihong 邹礼洪, "Qing mo Chuanbian tun ken yu mu zheng di wenti tanxi 清末川边 屯垦与牧争地问题探析," Xihua daxue xuebao (zhexue shehui kewen ban) 西华大学学 报（哲学社会科学版）3, no. 4 (2005): 29.

${ }^{32}$ Ren Naiqiang, Xikang tujing: minsu pian, 267.
} 
契) to the settlers to all the land they had cultivated. Such titles only gave farmers and their decedents use-rights. Zhao reiterated his prohibition of buying and selling land several times.

Cultivated land is state property (guojia gongchan 國家公產). It is different from property one inherits from ancestors (zuye 祖業). As long as farmers (ken $h u$ 墾戶) pay rent, the land shall be theirs in perpetuity. If any farmers leave the settlements (tun 屯), they must report to the settlement administration, which will take over management of the land. Members of the settlement may not sell or mortgage their land for profit. In order to prevent abuses no person may privately sell land. ${ }^{34}$

In 1911 Zhao did permit land to be "sub-let to appropriate persons," though he reminded settlers that they "may not sell one inch of land" and warned them that if subtenants caused any problems, the original tenant would be held responsible. ${ }^{35}$

A text produced by Zhao's administration in May 1910 and reprinted in the Republican period gazetteer for Zayu County was addressed to prospective settlers to Kham (though it is unclear how exactly it would have been presented to them). It made grand claims about the fertility of the environment (to which we shall return in the third section of this chapter). But the author was careful not to make false promises regarding the kind of land rights they would have. "After three years when you have repaid any loans for seeds and oxen, the government will give you title to the land allowing you to work it in perpetuity (yongyuan guanye 永遠管業) at no cost other than the same tax rates that apply in the interior.”36 The term suoyou quan 所有權, ‘full ownership rights', was never used in the Qing

\footnotetext{
${ }^{33}$ Deng Qiancheng, "Lun Qing mo Chuanbian kenzhi," 58. The Bathang Reconstruction Articles stated that those who had received government loans for food rations had to pay their entire harvest to the state; i.e. one could not defer repayment of the loan. $Q C B D$, 1:97-98.

${ }^{34} Q C B D, 1: 97-98$. The prohibition on selling land is implied rather than explicitly stated in the original Bathang Articles. A series of memorials and regulations in 1909 and 1910 explicitly forbid settlers from selling their land, see $Q C B D, 2: 468,661 ; 3: 1049$. The term guan dian occurred in the original Bathang Articles.

${ }^{35} \mathrm{QCBD}, 3: 970$.

${ }^{36} Q C B D, 2: 667$.
} 
documents from Kham. As we shall see in chapter five, an emotive discourse developed around it in the Republican period.

Zhao was not tolerant of settlers who tried to work outside the system, or go to places that had not been approved. When Liu Huikun 劉輝坤, a surveyor employed by the frontier administration, developed a plan for a settlement at Lithang, Zhao wrote:

When the gentleman (shen 紳) came beyond the pass he was tasked with surveying potential cultivation areas. This was not a licence to begin cultivating, and it goes without saying that he had no right to involve himself in other matters. Recently we received a telegram from Liu requesting permission to begin cultivation at Lithang, and also mentioning mining in that region. This involved many breaches of his legitimate authority; his conduct was absurd (guaimiu 乘謬) and he was ordered to stop. Contrary to expectation, the gentleman disobeyed the orders, and began cultivation and hydraulic mining [...] This gentleman is ordered to leave the frontier without delay. ${ }^{37}$

In non-agricultural industries there were actually restrictions on migration and settlement. In mining and medicine gathering, Zhao showed a strong preference for both the state and private entrepreneurs to use local labour, rather than Han migrants. The state mine at Derge paid Tibetans to learn mining techniques, not migrants. ${ }^{38}$ For the leather factory that was established at Bathang, Zhao preferred to hire "20 talented borderlanders (bianmin 邊民)” and send them to Sichuan to study tanning techniques, rather than hiring Sichuanese workers to go to Bathang. ${ }^{39}$ In 1909 the Daocheng commissioner Zhang Zhongliang 張中亮 received orders to investigate local medicinal resources as well as those gathering them, and to draft regulations to govern the growing trade in medicines so as to prevent discord. ${ }^{40}$ He gave an account of a group of migrants who had come to dig medicines. Zhang had ordered them to leave, and commanded the "Barbarians" to gather the herbs themselves. We are told that he warned

\footnotetext{
${ }^{37}$ Zhao Erfeng and Wu Fengpei, Zhao Erfeng Chuan bian zou du, 73.

${ }^{38}$ Ma Jinglin, Qing mo Chuanbian Zang qu gaitu-guiliu, 161.

${ }^{39}$ Zhao Erfeng and Wu Fengpei, Zhao Erfeng Chuan bian zou du, 95-96.

${ }^{40}$ QCBD, 2:453-4.
} 
them that if they did not, “outsiders” (pangren 旁人) would return to contend for this profit. Zhao's approving comment was:

The medicines that grow on the ground of mountains should belong to the local Barbarians to gather and sell. In order to avoid disputes, merchants may not employ people from afar to do this. The commissioner must give instruction to prevent [locals] from being confused by tales of mountain spirits and therefore wasting opportunities to profit, which causes others to greedily covet [these resources]. At the present time the government should not levy tax, so as to facilitate commerce and benefit the people. Later, when commerce is flourishing, it will be appropriate to begin taxation. ${ }^{41}$

In another case, some settlers requested to be allowed to do something other than crop growing, and again Zhao's response was to order them to leave the highlands. ${ }^{42}$

The system in 1900s Mongolia and Manchuria would have suited better the aspirations of Liu Huikun or the would-be medicine gatherers. In Mongolia and Manchuria the state retained the same theoretical monopoly on initiating development of wasteland, though it was often laxly enforced. ${ }^{43}$ From 1902, local authorities in the northeast and the Mongol territories were charged with “reporting land for cultivation” (baoken 報墾). Here, however, local authorities simply auctioned off plots of land to the highest bidder. ${ }^{44}$ Unlike in Kham, one did not have to cultivate land in order to obtain rights to it. Another difference was that those who purchased land from a government bureau were free to on-sell it, use it as collateral for a loan (dianya 典押) or rent it out to others. ${ }^{45}$ This enabled a whole class of settlers who, as Lattimore reported, "have capital, which they raise by selling out the land they have previously developed and enhanced in value

\footnotetext{
${ }^{41}$ Ibid., 454.

${ }^{42}$ Ibid., 398-99.

${ }^{43}$ Reardon-Anderson comments that "In practice, it was occupied and used by whoever got there first.” Reardon-Anderson, Reluctant Pioneers, 75.

${ }^{44}$ Ibid., 79.

${ }^{45}$ Ibid.
} 
in order to move on.” ${ }^{46}$ Lattimore wrote this in the 1930s-when the same strategy would have been possible in Kham-but he indicated that the process of buying, improving and selling land as a career "worked out in terms of continuous generations, not a single lifetime”, so the practice must have begun in the late Qing. ${ }^{47}$

Zhao Erfeng's system in Kham was much closer to most Qing precedent than was the system in 1900s Mongolia and Manchuria. In 1649, Dorgon, the Shunzhi 順治Emperor's regent, declared that landless migrants who cultivated abandoned land in Manchuria would receive permanent property rights. ${ }^{48}$ But as in 1900s Kham, settlement was closely regulated and monitored. Migrants had to register at the Shanhai Pass 山海關, where officials assigned them specific plots of land in southern Manchuria. In the Kangxi, Yongzheng and Qianlong reigns, farming colonies (tun 屯) in which land was owned by the state were established in the northwest and Xinjiang to facilitate the military campaigns against the Zhungar Mongols and provide for garrisons and civil administration following the Zhungars' defeat. $^{49}$ Tun also existed in interior China. Conditions were not uniform, but often households in tun were not allowed to leave the settlements, which leads one historian to describe the residents of the most restrictive tun as “state serfs” (guojia nongnu 国家农奴). ${ }^{50}$ By the late nineteenth century the tun had mostly died out due to a mixture of, at first, illegal and, later, legalized sales of settlement land. ${ }^{51}$ However, in the Sichuan frontier, Xiliang and Zhao Erfeng stuck with the concept and the language. In a 1904 report from a Bathang quartermaster to Xiliang made no mention of

\footnotetext{
${ }^{46}$ Owen Lattimore, "Chinese Colonization in Manchuria," Geographical Review 22, no. 2 (1932): 190-91.

${ }^{47}$ Ibid.

${ }^{48}$ Christopher Mills Isett, State, Peasant and Merchant in Qing Manchuria, 1644-1862 (Stanford: Stanford University Press, 2006), 32.

${ }^{49}$ Perdue, China Marches West, 343.

${ }^{50}$ Wu Tingyu 乌廷玉, "Qing chao tun tian 清朝屯田." Shixue jikan 史学集刊 no. 4 (1996): 34.

${ }^{51}$ Perdue, China Marches West, 347; Wu Tingyu, "Qing chao tun tian," 35.
} 
contemporary Manchuria, but listed sites that could be cultivated to provide for soldiers' rations, "in the spirit of the old tun colonies" (shi yi gu tun tian zhi yi yi 是亦古屯田之遺意). ${ }^{52}$ The same year, the post of Drango tun administrator (tunyuan 屯員) was created for a large region between Dartsedo and Danba. The post existed until 1911 and the officer clearly had an important role in organizing settlements. ${ }^{53}$

Zhao made some minor adjustments to the way that tun had been organized in the earlier periods of the dynasty. In previous centuries, tun households usually had rights to a fixed area of land, typically around $30 \mathrm{mu}$, while Zhao's system only conferred settlers with rights to land they had actually cultivated. This was possibly Zhao's response to the problem that in many earlier tun, households did always not cultivate all the land that had been granted to them — which could cause good land to remain huang.

One of Zhao Erfeng's policies that really did diverge from most early and mid-Qing notions of good frontier governance was his decision to grant soldiers who married local women an extra dou of highland barley per month. ${ }^{54}$ In the past, the Qing government had often prohibited marriage between Han and non-Han in the southwest. ${ }^{55}$ Some present day Chinese historians have seen the extra rations Zhao granted such couples as a measure designed to encourage intermarriage. ${ }^{56}$ As we shall see in chapter seven, many Republican era writers argued that their government should adopt policies to encourage intermarriage in order to foster the integration of Han and non-Han populations. That chapter will also show that Zhao's cultural policies were framed quite differently from most Republican period assimilationism. Zhao certainly wanted a strong and unified China, yet he does not seem to have seen the Tibetans as potential separatists who might

${ }^{52} Q C B D, 1: 10$.

${ }^{53}$ See $Q C B D$, 2:317, 548; 3:979.

${ }^{54}$ Zhao Erfeng and Wu Fengpei, Zhao Erfeng Chuan bian zou du, 145.

${ }^{55}$ Giersch, "'A Motley Throng:" Social Change on Southwest China's Early Modern Frontier, 1700-1800," The Journal of Asian Studies 60, no. 1 (2001): 86.

${ }^{56}$ Liu Xiangxiu 刘祥秀 and Guo Pingruo 郭平若, "Qing mo tun ken zhengce zai Chuanbian Zang qu de shishi ji dui huanjing de yingxiang 清末屯垦政策在川边藏区的 实施及其对环境的影响," Xizang yanjiu 西藏研究, no. 2 (2007): 19. 
want to split from an imagined national family: the dangers came from upstart renegade local leaders or foreign imperialists. It is likely that the rationale for the extra rations for soldiers who married was economic rather than assimilationist. Married soldiers who started households could eventually become less reliant on the state for their upkeep, which was, after all, the aim of tun settlements. How quickly and how much soldiers could have been weaned off the state via such means would depend on the details of the policy, something which is lacking in the documents used by this study. In the early 1620s, Nurhaci arranged for Manchu soldiers to be billeted with Han households in Liaodong for similar economic reasons. ${ }^{57}$ Even here, then, Zhao was perhaps not completely outside the realm of Qing precedent, though how much he knew about the early Manchu colonization of northern China is unclear.

Mining, Medicines or Crops? Priorities in Development.

Lu Chuanlin had pinned great hopes on mining in Nyarong, envisaging that it would pay the whole cost of the junxian administration that he wanted to impose on Kham. ${ }^{58}$ However, after the arrival of Xiliang, visions for Kham were generally characterized by a bias towards crop-growing and against resource extraction industries like mining. As Wang Xiuyu has commented, "more than other policies, land reclamation received broad support from relevant officials at the metropolitan and provincial levels." 59 Of the very limited developmental initiatives that he proposed, Xiliang wrote: “Once cultivation is underway in Bathang, it will be relatively easy to undertake the same at any other places that are found to be suitable for growing crops.

\footnotetext{
${ }^{57}$ Gertraude Roth, "The Manchu-Chinese Relationship, 1618-1636," in From Ming to Ch'ing: Conquest, Region, and Continuity in Seventeenth-Century China, ed. Jonathan D. Spence and John E. Wills (New Haven: Yale University Press, 1979), 14-15.

${ }^{58} \mathrm{Wu}$ Yanqin 吴彦勤, Qing mo min guo shiqi Chuan Zang guanxi yanjiu 清末民国时期川 藏关系研究 (Kunming: Yunnan renmin chubanshe, 2006), 45-46.

${ }^{59}$ Wang Xiuyu, "China's Last Imperial Frontier", 303.
} 
Afterwards, pastoral farming and mining can be trialled in turn.”60 Despite the preference for farming, Xiliang was not completely averse to mining, though he seems to have preferred to support operations begun by enterprising locals, rather than initiate anything new. He sent 10,000 taels to the Mingzheng tusi who had long wished to open a gold mining operation at Taining, but had been frustrated by opposition from the local lamas. ${ }^{61}$ However, this was still a far cry from the scale of mining that Lu Chuanlin's unrealized plan had envisaged.

Zhao Erfeng's interest in mining was greater than Xiliang's, but his prioritization was the same. In 1907, Zhao gave an overview of his plans for Kham, in which he stated:

Originally I believed we could wait until all the other undertakings were underway and then, in time, consider mining. However the mineral wealth of the Sichuan and Yunnan borderlands is great indeed, and if the state (guan 官) does not establish mining operations first [i.e. before others] there will likely be disputes and conflicts. ${ }^{62}$

In the text that followed, mining was still dealt with last and most briefly.

We propose to appoint a Chinese graduate of a foreign geology course to undertake a survey. The state (guan 官) can establish mining operations at sites where ore is most plentiful. Local mining methods will be used, and the miners will be employed [by the state]. We will seek to improve panning and smelting techniques and if it proves necessary, machinery can be employed. ${ }^{63}$

By 'machinery' Zhao probably meant something like the waterwheel driven batteries of stamps that had been in operation in the Maha gold mine (near Mianning in Ningyuan) since the 1880s. ${ }^{64}$ Ruling out the import of

\footnotetext{
${ }^{60} \mathrm{QCBD}, 1: 4$.

${ }^{61}$ Des Forges, Hsi-liang and the Chinese National Revolution, 74.

${ }^{62}$ Zhao Erfeng and Wu Fengpei, Zhao Erfeng Chuan bian zou du, 48.

${ }^{63}$ Ibid., 54.

${ }^{64}$ R. Logan Jack, The Back Blocks of China: A Narrative of Experiences among the Chinese, Sifans, Lolos, Tibetans, Shans and Kachins between Shanghai and the Irrawadi (London: Edward Arnold, 1904), 101-02.
} 
such equipment, his plan was to proceed slowly with mining. State operated or supported mines would use simple, local techniques first, and adopt the machinery necessary for hard-rock mining only when it proved necessary, presumably when known placer deposits had been exhausted. After all, if the aim was only to stake out claims for the state-either to stop anyone else getting there first, or "prevent disputes"-then why make the effort of importing heavy machinery? That task would have been difficult, though not much more difficult than transporting cannon around Kham (see chapter four).

Nevertheless, Liu Shilun 劉軾輪, the promised Chinese geology graduate of an American university arrived in 1908. He wrote reports of several locations, noting significant gold deposits in Taining, Dengzhanwo 燈盏窩, and that mining at a certain site in Lithang would be "extremely worthwhile (ji ke kaiban 極可開辦).”65 Liu also designed two pieces of hydraulic mining machinery that would suit the conditions of the region. ${ }^{66}$ Neither appears to have been built. He left only one year after he arrived, officially because he found the highland environment too harsh. ${ }^{67}$ There was perhaps more to his departure than physical discomfort. The account of the missionary Flora Shelton, based on hearsay rather than first-hand information but nonetheless suggestive, was:

A young Chinese mining engineer, educated in America, came in at the invitation of General Chao [Zhao] to discover gold. It was not to be found in the Bathang valley, a little lead being all he could discover. The great General was very angry, and threatened to take off the engineer's head. He started for America post haste and was hidden by missionaries at every stop so the "big man" could not find him. ${ }^{68}$

\footnotetext{
${ }^{65}$ Liu Xiangxiu 刘祥秀, "1903-1949 nian guojia bianjiang kaifa zhengce xia de Kang qu tudi liyong ji qi huanjing bianhua 1903-1949 年国家边疆开发政策下的康区土地利用 及其环境变化" (Shaanxi Normal University, 2007), 27; QCBD 2:230-33.

${ }^{66}$ Ren Xinjian, "Jindai Sichuan Zang qu de huangjin kaifa," 41.

${ }^{67}$ Ibid.; Liu Xiangxiu, "1903-1949 nian guojia bianjiang kaifa zhengce xia de Kang qu", 27.

${ }^{68}$ Flora Beal Shelton, Shelton of Tibet (New York: George H. Doran Company, 1923), 136.
} 
Most sources describe Liu's mission as extremely expensive at 10,000 taels. ${ }^{69}$ Apart from this, an additional 3,000 taels were spent on ordering equipment from San Francisco, although in the end it was used elsewhere in Sichuan rather than in Kham. ${ }^{70}$ A small state operated mine was established at Derge in 1909 at a cost of 700 taels. ${ }^{71}$ Other spending may have been hidden in county government budgets - though the same may be said for any other category of expenditure. 13,700 was no small amount, but it was much smaller than the 60,000 taels spent on cultivation work (kenwu 墾務) in 1906 alone. $^{72}$ In 1911 the administration budgeted 40,000 taels for cultivation and nothing for mining. ${ }^{73}$ One Bathang official reported that the total costs of promoting cultivation were "uncountable"; Zhao himself calculated five or six taels in silver were spent for every mu cultivated around Bathang. ${ }^{74}$ The cultivation expenses went towards provisions for loans for settlers' travel expenses, agricultural equipment, beasts of burden, seeds, housing and food until their land was productive. ${ }^{75}$ As a Shanghai journalist writing in the 1930s put it, the "[cultivation] plan was detailed and treatment [of colonists] comprehensive, it can be said that nothing was omitted." ${ }^{76}$ The loans were supposed to be paid off as settlers' lands became productive, but Zhao expected officials to be lenient, and ruled that they were not to demand compensation in case settlers damaged borrowed tools. $^{77}$

\footnotetext{
${ }^{69}$ Ren Xinjian, "Jindai Sichuan Zang qu de huangjin kaifa," 40-41.

${ }^{70}$ Ibid., 41.

${ }^{71}$ Ibid., 42.

${ }^{72}$ He Yimin 何一民, "20 shji chu nian Chuanbian Zangqu zhengzhi jingji wenhua gaige shulun 20 世纪初年川边藏区政治经济文化改革述论," Xinan minzu хиеуиап хиеbao 西 南民族学院学报（哲学社会科学版） 22, no. 6 (2001): 43.

${ }^{73}$ Chen Dongfu 陳東府, "Zhao Ji he jingying Xikang zhi jingguo 趙季和經營西康之經過 ," Kangdao yuekan 1, no. 1 (1938): 22-24.

${ }^{74}$ Deng Qiancheng, "Lun Qing mo Chuanbian kenzhi," 59. And Zhao’s estimation probably only included the cost of the state aid to settlers, and not the costs of his military campaigns.

${ }^{75}$ Ibid.: 57-58.

${ }^{76}$ ZYDZ, "Diaocha ziliao," Chuanbian jikan 1, no. 1 (1935): 171.

${ }^{77} \mathrm{QCBD}, 3: 973$.
} 
Zhao's interest in state-supported mining never seriously threatened to distract his attention from state-supported agriculture. The Derge mine mentioned above was the only state operated gold mine established on Zhao's watch, and it was a much smaller endeavour than many other mines in the southwest, employing only 200 men at its peak. ${ }^{78}$ Here, the state provided rations for two months for Tibetan trainee miners. Apart from that, it merely allowed people to mine there, and collected tax from them every six months. Various accounts also mention a state operated copper mine but none indicate how large it was or how much money the government invested in it. ${ }^{79}$ Two other state operated gold mines existed in Kham, but they had been established prior to Zhao's appointment in the region-and given that the Taining mine had been established by the Mingzheng tusi, albeit with funding from Xiliang, its status as a "state mine" is perhaps somewhat questionable. $^{80}$

Even though mining was a much lower priority for the state than cultivation, Zhao did create rules designed to encourage private prospecting. Private enterprises in their trial stages of operations (shiban 試辦) only had to pay two thirds as much tax as established enterprises. ${ }^{81}$ Lone miners or bands of up to six who worked a site by themselves were not taxed at all, which Chinese historians have described as another "favourable" policy designed to encourage development. ${ }^{82}$ Quite possibly, however, this merely signalled that tracking down scattered individuals and gangs in remote valleys cost more than the value of the tax that they could be made to pay.

Unsurprisingly given Zhao's general approach to migration, mining entrepreneurs also had to put up with significant restrictive regulation. When entrepreneurs applied for mining licenses, they had to state how many employees they would have, and not employ more or less without obtaining

\footnotetext{
${ }^{78}$ Ibid., 42.

${ }^{79}$ He Yimin, "20 shji chu nian Chuanbian Zangqu zhengzhi jingji wenhua gaige shulun," 44.

${ }^{80}$ The other state operated gold mine was at Sandaoqiao in Kangding, and had been established by the Liu Tingshu, the pro-mining magistrate at Dartsedo.

${ }^{81}$ Liu Xiangxiu, "1903-1949 nian guojia bianjiang kaifa zhengce xia de Kang qu," 31.

82 Ibid.
} 
permission. ${ }^{83}$ To the owner of one of the mining operations at Lithangwho is described in accounts as a "local merchant"-Zhao wrote: "This mining area is more than 300 zhang 丈. If the trial period comes to a successful conclusion, the merchant must hire more workers, otherwise the license will be cancelled.” ${ }^{84}$ Employers were warned to exercise firm control over their employees. All gold had to be sold to the state at official prices, and no foreign investment was allowed. ${ }^{85}$

Mining did not constitute the only area of government expenditure on economic development apart from its encouragement of crop growing. The administration is also reported to have spent 24,000 taels on a tannery in Bathang. ${ }^{86}$ This is significantly more than its expenditure on developing mining, but overall spending priorities were almost the reverse of those of the regional state in the late Republican period. The latter's expenditure on industrial projects was more than double what it spent on agricultural development. $^{87}$

Wang Xiuyu argues that the government's decision to direct the bulk of its energy and resources into crop farming rather than mining was essentially a rational one:

Keenly as Zhao knew the importance of all his projects, he had little option but to prioritize army training, reclamation and commercial tea taxation above mining and the rest, as troops were essential for security and the other two could produce revenue more quickly but required relatively less investment. Industrial mining suffered from fiscal problems at the outset. ${ }^{88}$

\footnotetext{
${ }^{83}$ Ibid., 115.

${ }^{84}$ Ren Xinjian, "Jindai Sichuan Zang qu de huangjin kaifa," 43.

${ }^{85}$ Lai Zuozhong 来作中, "Jiefang qian Ganzi Zang qu de huangjin shengchan 解放前甘孜 藏区的黄金生产," in Ganzi Zhou wenshi ziliao, no. 14 甘孜州文史资料，第十四辑, ed. Zhongguo renmin zhengzhi xieshang huiyi Ganzi Zangzu zizhizhou weiyuanhui 中国人 民政治协商会议甘孜藏族自治州委员会 (Kangding: Kangding xian yinshua chang, 1996), 116.

${ }^{86}$ Ma Jinglin, Qing mo Chuanbian Zang qu gaitu-guiliu, 161.

${ }^{87}$ See Xikang sheng canyihui 西康省參議會, "Linshi canyihui, di san ci hui huibian 臨時 參議會第三次會匯編," 1942, (SCDAG, QZH: 204, AJH: 16), 73-43.

${ }^{88}$ Wang Xiuyu, "China's Last Imperial Frontier," 327.
} 
In Wang's view, Zhao did not have any ideological preference for crop farming over mining. He simply calculated that investment in the former was likely to pay off more quickly than investment in the latter. Certainly, after Liu's departure, the idea that his whole mission had been a great disappointment appears to have grown up among some officials. ${ }^{89}$ Morevoer, Zhao was a military leader whose attention was occupied with ensuring military control of a very large area of territory. Naturally he was anxious to ensure a supply of food for his soldiers. Transporting provisions from Sichuan was expensive and meant that his soldiers sometimes went hungry. ${ }^{90}$ So his focus on the development of communities of crop growers that were fairly well tied to the land was partly related to the need to guarantee a reliable supply of grain for his soldiers wherever political developments might take them.

However, we should not push this thesis too far. Zhao's force was big enough that it would have greatly stretched the resources of any particular location in Kham, but its impact on the whole region should have been fairly negligible. We saw above that there is some uncertainty as regards the actual size of the Qing army in Kham. But even the higher figure of 4,000 still amounts to a fairly small force. The Qing government had stationed armies of this size in Kham before. Taining alone had been host to a garrison of 3,000 soldiers during the Yongzheng reign. ${ }^{91}$ The Yongzheng emperor had not found it necessary to launch a land cultivation program paralleling Zhao Erfeng's. (Mobilization during the Jinchuan wars utterly dwarfed both that of the Yongzheng reign and Zhao Erfeng's, but these wars were enormously expensive and probably unaffordable for the central government by the twentieth century. ${ }^{92}$ ) Reports of the Zhao

\footnotetext{
${ }^{89}$ Fu Songmu, Xikang jiansheng ji, 11; QCBD, 2:440.

${ }^{90}$ Deng Qiancheng, "Lun Qing mo Chuanbian kenzhi," 57.

${ }^{91}$ Ren Naiqiang, Xikang tujing: minsu pian, 247.

92 In the first Jinchuan war (1747-1749), 70,000 soldiers fought for the empire, supported by some 200,000 military labourers, at a total cost of more than 7.6 million taels of silver. The second Jinchuan war (1771-1776) saw the government mobilize 129,500 soldiers and 462,000 military labourers at an astonishing cost of 61.6 million taels of silver. Yingcong Dai, "The Qing State, Merchants, and the Military Labor Force in the Jinchuan
} 
administration's land tax income vary slightly. One source gives an income of 20,000 shi of grain per year, another $30,000 .^{93}$ Either of these amounts should have been sufficient to feed 4,000 troops. Food was certainly expensive in Kham, but there were no instances of starvation that I am aware of, or cases in which food shortages were the source of unrest. Furthermore, according to Fu Songmu, "In the beginning, the troops ate tsampa and other kinds of grain, but they were afflicted with stomach ailments ( $\mathrm{fu} \mathrm{ji}$ 腹疾), so the army began purchasing rice in the interior and transporting it to the frontier in order to supplement their diet."94 Importing food from outside had more to do with the army considering local food unpalatable than there simply not being enough of it. As well shall see in chapter five, transport was a critical problem for Zhao Erfeng and later governors, but food was only one of the goods that needed to be transported.

Moreover, there is no evidence that the investment in agriculture yielded a better return, per tael spent, than the investment in mining, and there is little reason to think that a neutral observer could have imagined it would. Zhao Erfeng's agricultural policy was extraordinarily expensive, but did not produce the great results that were hoped for, as we shall see below. These huge costs were the target of criticism from some within the frontier administration, who did not see it as money rationally spent. In 1909, a Bathang official reported that: "Cultivation has been one of the core policies of the Bathang administration, but careful investigation of the results reveals that in reality it is not worth the effort (de bu chang shi 得不償失)." 95 In 1910 another official argued for giving up on supporting migrants to come from other parts of China, and getting the indigenes to do more cultivation instead:

Campaigns," Late Imperial China 22, no. 2 (2001): 39., Li Hongbin 李鸿涁 and Bai Jie 白杰, "Ping Qianlong chao Jinchuan zhi yi 评乾隆朝金川之役," Qing shi yanjiu 清史研 究, no. 2 (1998): 70.

${ }^{93}$ Huang Fensheng 黃奮生, ed. Meng Zang xin zhi 蒙藏新志 (Shanghai: Zhonghua shu ju,1938), 895; Yang Jianwu 杨健吾, "Minguo shiqi kangqu de jinrong caizheng 民国时 期康区的金融财政," Xizang yanjiu 西藏研究, no. 3 (2006).

${ }^{94} \mathrm{Fu}$ Songmu, Xikang jiansheng ji, 34.

${ }^{95}$ QCBD, 3:728. 
Huang land is unlimited, but the government's resources are limited. [...] There are those that argue that in order to build up the border country (shi bian 實邊) it is necessary to promote colonization (kenzhi 墾殖). Although this theory has its logic, unfortunately the commissioners (weiyuan 委員) ${ }^{96}$ have not organized it well; many of the colonists have run off, and such a sum of money has been wasted that adding it all up causes one to sigh in exasperation. Thus it would be better to change strategies, to gradually get those nomads who have no form of livelihood ${ }^{97}$ to widely cultivate the vast earth. This will make the people's lives richer, and the earth more fertile. ${ }^{98}$

Clearly, the author of the second quote still supported cultivation, though it is less certain that the former did. But neither saw that the current cultivation program as a rational investment. Wang's argument that the prioritization of crop-growing over mining was a logical choice to allocate funds to the most promising activities is at odds with the views of some contemporary observers.

In addition to military supply issues, there were a couple of important ideological influences on Zhao’s policy making. Most late imperial Chinese officials held a strong physiocratic belief that, more than anything else, expanding crop production generated wealth. As the magistrate of Darstedo wrote in 1908: “If we wish to grow our wealth (kuo liyuan 擴利源), it is necessary to use every ounce of the earth’s resources (jin di li 盡地力), and cultivate the open lands (kuang $t u$ 曠土). Fields cannot be allowed to go waste."99 The phrase "use every ounce of the earth’s resources”, translated as "exhaust the earth" by Perdue, was a key item in the vocabulary of late imperial Chinese political economy. ${ }^{100}$ As we saw above, a couple of lower-

\footnotetext{
${ }^{96}$ Although Zhao Erfeng's office is sometimes translated as "Commissioner", the writer is not referring to Zhao here; the Chinese titles for Zhao's office and those referred to here are different. It is Zhao's underlings who are the direct object of criticism.

97 “Wu ye youmin 無業游民.” It is unclear whether he thought that all nomads have no proper livelihood, or just that some did not.

${ }^{98} Q C B D, 3: 724$.

${ }^{99} Q C B D, 1: 241$.

${ }^{100}$ Perdue, Exhausting the Earth: State and Peasant in Hunan, 1500-1850. (Cambridge, Mass.: Council on East Asian Studies, Harvard University, 1987), 11-12.
} 
ranking officials in Zhao's Kham administration did suggest that the costs of increasing land cultivation in Kham were greater than the benefits. Yet, where a clear and present environmental cost was not a factor, such thinking ran counter to the weight of Qing statecraft thought.

Zhao also had a very strong preference for fixed settlements over mobile labour. Fairly, or unfairly, there was a connection in his thinking between banditry and non-agricultural labour. Regulations for a private mine in Lithang stated: "There is to be a roll with the names of all the miners on site, and each of them is to carry their license. This is to prevent deception (menghun 蒙混) and infiltration by bandits (fei lei qianliu 罒类潛流).”101 Xiliang also showed great concern about the moral character of Han migrants to the frontier. One of the criteria for entrants to the Tibetan language school in Chengdu (for prospective Han administrators of the highlands) was that they had to "have clean (qingbai 清白) family backgrounds." This contradiction between a desire to promote migration and an element of suspicion directed towards potential migrants is a theme to which we shall return in chapter seven.

\section{Environmental Knowledge}

Eliot Sperling has argued that Zhao "gave an exceedingly optimistic evaluation of the prospects for settlement of the frontier region”. ${ }^{102}$ Likewise, in 1936, Ren Naiqiang was scathing about the standard of officials' knowledge about the Kham environment, both in the Qing and during his own time.

Government officials who have a superficial acquaintance with the border region all love to rave (wang tan 妄談) about cultivation (kaiken 開墾). In the time of Zhao Erfeng, kaiken was promoted vigorously.

\footnotetext{
${ }^{101}$ QCBD, 3:937.

${ }^{102}$ Sperling, "The Chinese Venture in K’am", 20.
} 
Settlers (kenmin 墾民) from as far away as Hubei were recruited. Cultivation zones (ken chang 墾場) were established, with housing and oxen for the farms. In two years, expenses totalled more than 100,000 [taels], but not one ounce of grain was harvested and the settlers all ran off. The cultivation zones were generally on grasslands above 4,000 meters in altitude, but the crops that were planted, were those such as cotton and rice that will not grow above 2000 meters. This was an unscientific fantasy (weifan kexue zhi miming 違反科學之謎夢), from which the officials of the border region still have not woken to this day. ${ }^{103}$

Elsewhere he wrote:

Zhao Erfeng [...] allocated a large sum of money to recruiting settlers from Sichuan, Hubei and other provinces and transporting them to Kham. Cultivation zones were established at Bathang [...] and Daocheng, Xiangcheng, Derong, Yanjing and other places. In total, the government recruited more than one thousand farmers (kenfu 墾夫). But at that time both the government and the people lacked general knowledge about cultivation. They were determined to grow rice, cotton, silk and sugar cane. But in the Kham region all of this failed. Those farmers with some knowledge began growing kinds of wheat, but they were only ten to twenty percent of the total. ${ }^{104}$

According to this view, the late Qing attempts to promote agricultural settlement in Kham were a naive, utopian blunder. But although Zhao's regime was not a paragon of environmental science and cutting edge agronomy, Ren's criticism would have been more accurate if it had been directed at certain intellectuals in the interior, rather than officials in the frontier.

Before Zhao's arrival in the frontier, the majority Han observers could hardly be accused of over-optimism regarding the prospects of agriculture in Kham. Lu Chuanlin wrote that in Kham: “the qi (氣) of the earth is bitterly cold, the five cereals will not grow, and thus it is not proper to recruit people to open up the huang.” ${ }^{105}$ As noted above, Lu hoped that mining rather than

\footnotetext{
${ }^{103}$ Ren Naiqiang, "Xikang yuncang de fu li yu jianshe de tujing 西康蘊藏的富力與建設的 途徑," Xibei wenti jikan 西北問題季刊 2, no. 1 (1936): 53.

104 Ren Naiqiang, Xikang tujing: minsu pian, 253-54.

105 Quoted in Deng Qiancheng, "Lun Qing mo Chuanbian kenzhi," 55.
} 
farming would pay the costs of his proposed frontier administration. In November 1903, several Sichuanese provincial government bodies including the Administration Commission (Buzhengsi 布政司), the Office of Commerce (Shangwu zongju 商务总局), the Surveillance Commission (Ancha shisi 按察使司) and the Office of Foreign Affairs (Yangwu zongju 洋务总局) wrote to the Ministry of Defence (Junjichu 軍機處), stating that "Only barley may be grown; the cultivation of rice is impossible. [...] [Furthermore] the land that is not already cultivated is used for raising livestock. It is not lying abandoned (bing fei qi di 並非棄地).”106

After the arrival of Zhao Erfeng, new and more positive ideas about Kham's environment began to be articulated. In 1907, Zhao wrote a long memorial outlining proposals for the development of the region. It contained what appear to be the first examples of claims that the frontier environment was generally very fertile and bountiful in resources. Referring to the whole region he wrote: "Although the weather is rather cold, in general the earth is extremely fertile (jun ji gaoyu 均極膏䑂).” 107 And “the Sichuan and Yunnan frontier country is rich in natural resources (chu chan shen rao 出 產甚饒).”108 Others in his administration adopted a similar tone. A surveyor dispatched to Zayu in what is now the south-eastern part of the Tibet Autonomous Region wrote in February 1910 that "There were fertile soils, convenient water resources, lush woods, and open valleys in all the places I travelled through." 109 One location impressed him so much that he suggested that "if this land were cultivated, a small effort would produce a great result. Harvests would possibly be greater than those on even the best land in Interior China.”"110

\footnotetext{
${ }^{106}$ QCBD, 1:1. Elliot Sperling translates a quote from a memorial attributed to Xiliang expressing the same idea: Sperling, "The Chinese Venture in K'am," 11.

${ }^{107} Q C B D, 1: 122$.

${ }^{108}$ Ibid., 1:124.

${ }^{109}$ Ibid., 2:567.

${ }^{110}$ Ibid., 2:567.
} 
The motivations of the surveyor are unclear, but Zhao's proclamation of frontier fecundity was probably related to his request, in the same memorial, for ongoing funding of three million taels annually from the central government. This was a large sum for a government in great financial difficulty. The appeal of solidifying control over a key part of the non-Han southwest might have convinced the court to finance Zhao's campaigns regardless of the region's economic prospects, but the idea that Kham was fertile and rich enough in resources to eventually pay its own way cannot have damaged his case. Other portrayals of Kham, or specific locations within Kham, as particularly fertile also tended to occur in discourse soliciting outside support. The 1910 text addressed to prospective settlers (quoted earlier in this chapter) gave an almost utopian account of Zayu:

We have received reports of a place called "Zayu", which is not more than 10 to 20 days journey from Bathang. It is a broad, flat valley and the weather is the same as Chengdu. It has always produced rice. [...] The Barbarian people (manzi 蠻子) are not lazy and they know how to grow rice, but there is too much land for their small population to cultivate. [...] Only about one percent of the arable land there is cultivated, there is still room for 10 million mu of paddy fields. Water resources are convenient; it is truly a great place. ${ }^{111}$

In his 1912 history of Zhao’s campaigns, Fu Songmu criticized unnamed Han people for being too pessimistic about the possibilities for expanding cultivation in Kham. The problem, from Fu's perspective had been exactly the opposite of the problem Ren Naiqiang diagnosed:

In the past [...] many Han held the trite belief that grain would not grow in the Barbarian lands. They generalized about the whole of Kham on the basis of the cold and inhospitable parts of it. ${ }^{112}$

Fu's work was not a direct request for money or recruits for a renewed settlement endeavour. But it served as a post-hoc legitimization of Zhao's campaigns and a hagiographic attempt to rehabilitate his mentor's reputation.

\footnotetext{
${ }^{111}$ Ibid., 2:666-67.

${ }^{112}$ Fu Songmu, Xikang jiansheng ji, 2:23.
} 
It was filled with comments such as "Everywhere people pledged their allegiance [to Zhao], and desiring to shake off the oppressive rule of the tusi, hutuktu ('living Buddha, Ch. hutuketu 呼圖克圖) and headmen, they pleaded with the Warden of the Marches for him to implement direct rule in their villages.” $113 \mathrm{Fu}$ also had a reason, personal rather than material, to argue that Zhao's forerunners' pessimism regarding the Kham environment had been misplaced.

Yet in communication that did not aim to garner more funding or settlers, Zhao was much more cautious about whether locations were suitable for an agricultural settlement. Before the surveyor quoted above wrote his February 1910 report extolling the advantages of Zayu, settlers arriving in Bathang had already heard of places further west that were said to be more suitable for cultivation. In July 1909, a Bathang quartermaster (liang yuan 糧員) reported that:

The settlers were unwilling to begin cultivation at Bamutang [in Bathang], and they requested to be allowed to go to Yanjing, where they had heard that two crops per year are possible and water resources are very convenient. [...] I had no choice but to allow them to go. ${ }^{114}$

Zhao Erfeng's puzzled and angry response demanded that the quartermaster order the settlers return to Bamutang. He asked why the official had felt he had no choice but to allow them to go to Yanjing. As we have already seen, this was not the first time that Zhao forbade settlers from going to places that he felt had not been properly surveyed, or that did not seem suitable enough for cultivation. When Liu Huikun wanted to establish a settlement at Lithang, Zhao denied him permission. He wrote tersely that "If the settlers did not starve to death, they would freeze to death." ${ }^{115}$ The simplest explanation for his refusal to allow migrants to go to places that had not been shown to be suitable is that sweeping claims about the bountiful frontier were mostly aimed at his grant-providers in Beijing.

\footnotetext{
${ }^{113}$ Ibid., 2:31.

${ }^{114}$ QCBD, 1:399.

${ }^{115}$ QCBD, 1:106.
} 
Zhao's real views were probably closer to those of the officials who had preceded him: there were a few locations that were suitable for agricultural colonies, but settlers risked starvation or pneumonia if farming colonies were established in carelessly chosen places.

Although Zhao himself probably did not believe Kham was generally extremely fertile and eminently transformable, many educated people back in interior China appear to have become convinced that this was indeed the case. A 1910 article in Datongbao 大同報 reported the impending transformation of the region:

The natives in the 2000 li wilderness beyond Dartsedo [...] only know the nomadic herding life, and are as yet unacquainted with crops and ploughs. Since the Warden of the Marches formulated a comprehensive plan to recruit settlers, the numbers of migrants to this previously untamed and ungoverned country has steadily increased. In no time at all it will have the prosperity and population of a great metropolis (yi zhuanshun ji chengwei fansheng du shi yi 一轉瞬即成為繁盛都市矣). ${ }^{116}$

The origins of this view are unclear. Was Zhao too successful at selling the notion of an abundant frontier? Yet the vision of the "prosperity and population of a great metropolis” went beyond anything that Zhao promised, even to his financiers. This sort of prediction was probably what led to the formation of the ill-fated Bathang Cultivation Company (Batang kenwu gongsi 巴塘墾務公司). The main protagonist behind the Company was Peng Jinmen 彭金門, a native of Leshan, who returned to Sichuan in 1906 from Japan, where he had been a student and had joined the revolutionary Datong Society (Datong she 大同社). According to one of his associates "the schools in Chongqing competed to employ him as a teacher, but he refused them all.” 117 For unknown reasons, Peng's real interest lay in agricultural settlement (kenzhi 墾殖) of the frontier, and he and several likeminded friends founded the Bathang Cultivation Company. Their efforts at

\footnotetext{
116 “Zhengjie xinwen: Chuanbian kaiken zhi jinzhuang 政界新聞: 川邊開墾之近狀”, Datongbao 大同報, (28.12.1910): 35.

${ }^{117}$ Yang Gengguang 楊耿光, "Sichuan Le-Ping kenwu gongshe nian yu nian lai zhi jingguo 四川樂屏墾務公社廿餘年來之經過," Chuanbian jikan 2, no. 2 (1936): 1.
} 
Bathang ended in disaster, though what exactly went wrong is unclear. Information on the company's original plan is similarly sparse, but, inspired by profit and patriotism it seems to have gone beyond providing food for garrisons and supporting an expanded bureaucracy. Ren Naiqiang's critique of late Qing settlement schemes was leveled at men with "superficial acquaintance with the border region” who “love to rave (wang tan 妄談) about kaiken". Evidence suggests that men such as those who formed the Cultivation Company were a more fitting target for such criticism than Zhao himself.

To what extent did Zhao's administration attempt to gather and disseminate more information about the Kham environment? Zhao employed a Japanese agronomist Kojima Ikeda 池田小岛, although there is scant information on how long he stayed in Kham or what exactly he did there. ${ }^{118}$ As part of his regime's efforts to increase settlement surveyors were dispatched to various locations throughout the region. They gave estimates, in mu of the area of huang land at various locations, noting whether water resources were convenient or not and sometimes how fertile it seemed to be. However, in contrast to the meticulous monitoring of harvests in the frontier colonies in the Qianlong era, Zhao's administration appears to have been quite lackadaisical about reporting harvests and cultivated area. As the historian Deng Qiancheng has pointed out, surveyors gave quite detailed reports of the area of huang land in $m u$ in different locations, but officials were vague and tardy when it came to reporting the number of settlers in their jurisdiction and the amount of newly cultivated land. ${ }^{119}$ It was not until October 1908 that the administration arranged for the production of standardized dou 斗 grain measurement units to be dispatched to county officials for the measurement of rations, harvests and

\footnotetext{
${ }^{118}$ Wang Chuan, "Qing mo, Minguo shiqi Xikang diqu de nongye gaijin ji qi shiji chengxiao 清末、民国时期西康地区的农业改进及其实际成效," Minguo Dang'an 民 国档案, no. 4 (2004): 55.

${ }^{119}$ Deng Qiancheng, "Lun Qing mo Chuanbian kenzhi," 59.
} 
taxes. ${ }^{120}$ Officials had been reporting grain yields in $k e$ 克, a transliteration of the traditional Tibetan grain measurement unit khal, which, as the 1908 memorial noted, varied in size throughout Kham. ${ }^{121}$ Given such variation, pre-standardization assessments of which places in Kham could produce the highest per mu grain yield must have been fairly impressionistic. Even after the October 1908 order to officials to use a standard dou measure, some continued to quote grain volumes in ke without explaining the size of the local ke unit. ${ }^{122}$

There was no attempt to gather knowledge of pastoral farming at all. Justin Tighe and others have noted a similar bias against pastoral farming in the late Qing and early Republican administration in Mongolia. ${ }^{123}$ Yet the Xinjiang administrations of Zhao's era were quite different in this regard. The 1910 Xinjiang Gazetteer noted that "Investigations show that the profits from pastoral farming are much greater than those from crop farming”. ${ }^{124}$ The gazetteer included roughly the same amount of information about livestock farming ( $m u$ 牧) in the province as it did about crop-farming (nong 農), and recorded things such as how many of horses, cattle or sheep a hired Mongol or Kazakh herder could look after. ${ }^{125}$ The attention that the Xinjiang administration gave to livestock farming must have been related in part to the stud and sheep farms it operated, which were revived versions of Qianlong era establishments. ${ }^{126}$ Yet interest in livestock in late Qing agronomy and frontier policy was not completely confined to Xinjiang. In 1901, Zhang Zhidong 張之洞 (1837-1909), who was in favour of agricultural colonization in Mongolia, argued for the development of

\footnotetext{
${ }^{120}$ QCBD, 1:250.

${ }^{121}$ Ibid., 96, 112.

${ }^{122}$ QCBD, 2:330-31.

${ }^{123}$ Justin Tighe, Constructing Suiyuan: The Politics of Northwestern Territory and Development in Early Twentieth-Century China (Leiden: Brill, 2005), 145.

${ }^{124}$ Yuan Dahua 袁大化 and Wang Shuwo 王樹枂, eds., Xinjiang tuzhi 新疆圖志 (Taibei: Wenhai chubanshe,1965 [1910]), "shiye, part 1", $13 b$.

${ }^{125}$ Ibid., "shiye, part 1", 15b-16a.

${ }^{126}$ Ibid., "shiye, part 1", 11b.
} 
livestock farming and animal science throughout China. ${ }^{127}$ That livestock farming was so absent from late Qing agronomy and strategies for agricultural development in Kham and Mongolia remains something of a mystery.

In 1910, La Shijun 喇世俊, the new magistrate of Dengke 登科 opened an experimental farm, though this appears to have been his own initiative rather than Zhao's. ${ }^{128}$ La submitted a report to Zhao requesting funding and listing 34 types of vegetables and grain that he proposed to trial. ${ }^{129}$ Zhao's response was:

The farm should concentrate on the five grains ( $w u$ gu 五谷 ${ }^{130}$ ), to serve as a model for the Barbarian people to study the art of crop growing. Vegetables are not a key aspect of agriculture (fei nongshi zhi yaoling ye 非農事之要領也). Furthermore, the report states that the earth is not suitable for the production of rice, and therefore this crop will not be trialled. What is the evidence for this? ${ }^{131}$

Apart from wanting a trial rice crop, Zhao believed the farm should have a pedagogical focus, rather than a knowledge-gathering one. La got the message: a later report detailed plans to improve indigenous agriculture, but did not mention any trial crops, with the exception of the rice, which had not gone well. ${ }^{132}$ La and Zhao were not giving up on rice, however. A strain of cold-water-rice (leng shui gu 冷水穀) from Kangding had been ordered. La's list of measures to improve indigenous agriculture included things such as the purchase and production of better ploughshares, the encouragement of weeding fields, as well as other practices characteristic of the intensive agriculture of the Interior. These may have boosted per mu yields, but

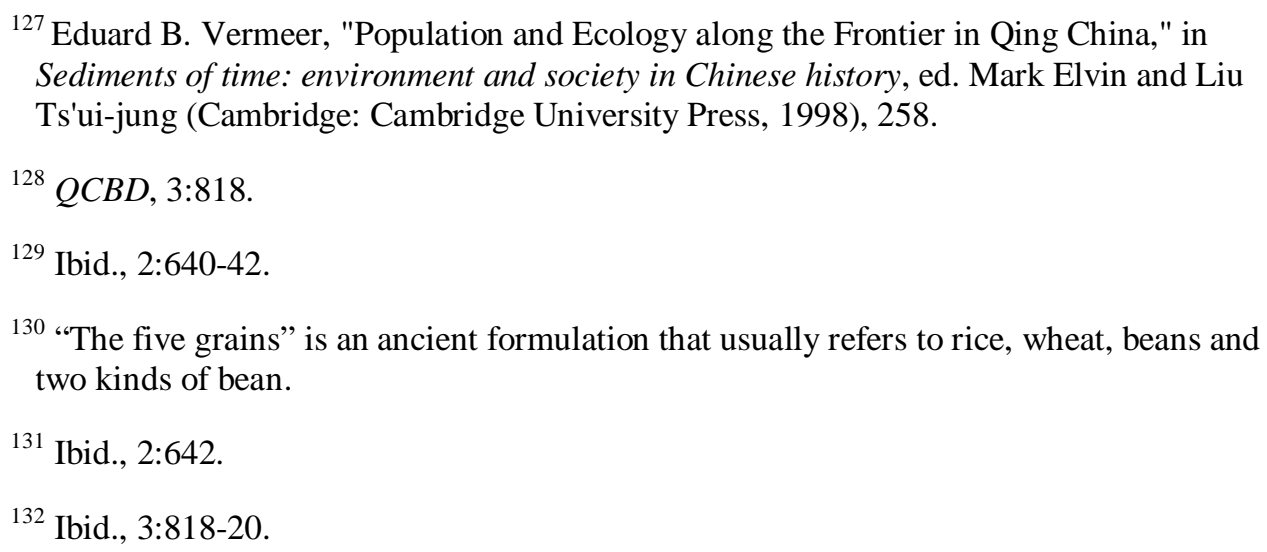


nobody appears to have considered whether or not such intensive application of labour to land was efficient for agriculture in a sparsely populated landscape.

\section{Outcomes of the Qing systems}

Present-day Chinese historians give mixed assessments of the outcomes of the Qing settlement programs. Li Maoyun is one of several who have argued that the systems were successful until the collapse of the Qing dynasty. ${ }^{133}$ However, Deng Qiancheng, who is one of the few historians who has attempted to quantify Han migration, argues that "it is beyond doubt that the results of migration and cultivation were disappointing.” ${ }^{134}$ Most estimates put the total number of new settlers who entered the frontier during the last five years of Qing rule at only around 2,000. ${ }^{135}$ According to the sources used by Liu Xiangxiu and Guo Pingruo, a total of approximately 20,000 mu was brought into cultivation between 1903 and $1911 .^{136}$ By contrast, in Mongolia, 2 million mu of former Mongol Yeke-juu league land had been officially measured, assessed and sold or rented to Han peasants by $1908 .^{137}$

Nor were commissioners in charge of cultivation overly impressed with the quality of the migrants the scheme attracted. ${ }^{138}$ A Bathang quartermaster reported to Zhao that

\footnotetext{
${ }^{133}$ Li Maoyu, "Lun Zhao Erfeng," 125.

${ }^{134}$ Deng Qiancheng, "Lun Qing mo Chuanbian kenzhi," 58. See also Zou Lihong, "Qing mo chuanbian tun ken yu mu zheng di wenti tanxi," 31.

135 Ibid.: 58. Chen Zhongwei says that the number of Han who entered the Xikang (Kham) region in the late Qing was 200,000. All of Chen's figures are substantially higher than other sources, however. A figure of around 2,000 settlers is also compatible with the estimation that 20,000 mu had been brought into cultivation. Chen Zhongwei 陳重為, Xikang wenti 西康問题 (Shanghai: Zhonghua shu ju, 1930), 89.

${ }^{136}$ Liu Xiangxiu and Guo Pingruo, "Qing mo tun ken zhengce zai Chuanbian Zang qu," 21.

${ }^{137}$ Justin Tighe, Constructing Suiyuan, 110. It is not clear, of course, whether all of the land sold or rented to Han in Mongolia was actually being cultivated. In fact, it is not even clear that this land was newly settled. Some of it might have been settled illegally for decades before the beginning of a new land settlement regime in Mongolia in 1902.

${ }^{138}$ Deng Qiancheng, "Lun Qing mo Chuanbian kenzhi," 59. Another official warned that "those who come from outside are likely to be a mixed group, with outstanding ones together with the undesirables. If regulations are not made appropriately, then the situation could be difficult to repair.” $Q C B D, 2: 317$.
} 
Concerning their motivation, half of them are rogues and hooligans (wulai liumang 无赖流讯), who come beyond the pass seeking refuge from the law (butaosuo 逋逃薮). Since they can get money from the Sichuan treasury [...] they say that they come to cultivate the land, but in reality they are not interested in cultivation. ${ }^{139}$

Another Bathang tax official Dong Tao, reported that new settlers frequently left without repaying their debts: "As soon as they have land assigned to them, they require loans of seeds and food in order to begin work, but if things are not exactly to their satisfaction, they simply run away, leaving the quartermaster with the costs of seeds and food they had loaned." ${ }^{140}$ Such complaints, however, indicate the failure of physiocratic visions for agricultural colonisation rather than the failure of settlers, as many migrants stayed in the highlands but went into other occupations (see chapter six).

Generally speaking, the replacement of tusi with Han administrators (gaitu guiliu 改土歸流) was a violent process that saw revolts break out and pacification campaigns unleashed in several regions. ${ }^{141}$ By allowing settlers to cultivate all the huang land that they could, Zhao showed complete confidence in the notion that land designated as such was empty and unused. This was not always the case, and Zou Lihong has demonstrated that despite the small numbers involved, the settlement programs caused land disputes between indigenous pastoralists and migrant farmers. ${ }^{142}$ Zou suggests that the government addressed this in an ad-hoc (and fairly ineffective) manner. Drango tun administrator Wu Qingxi ordered, for example, that

Farmers must build high embankments around all cultivated land that is near to routes used by livestock, so as to prevent crops being trampled. If the embankments are not high, and some livestock cross them by mistake,

\footnotetext{
${ }^{139}$ QCDB, 2:398.

${ }^{140}$ Deng Qiancheng, "Lun Qing mo Chuanbian kenzhi," 59.

${ }^{141}$ See for example Coleman, "The Uprising at Batang"; Sperling, "The Chinese Venture in K'am.", Adshead, Province and Politics in Late Imperial China.

142 Zou Lihong, "Qing mo chuanbian tun ken yu mu zheng di wenti tanxi," 29.
} 
trampling on the cultivated land, farmers must act reasonably, and may not block livestock or make demands. ${ }^{143}$

\section{Conclusion}

'Sinicization' is not a bad broad-brush term for what Zhao Erfeng hoped to achieve in Kham. But it glosses over the fact that his vision was not for a generic "Chinese" society in the region. He had specific targets and priorities that were different from those of some other Chinese leaders. The plan was to foster the growth of stable, rooted agricultural communities. They would be egalitarian societies in many ways. There could be no large landowners and settlers could only claim what they actually worked. Society would be tightly managed, and migration into non-agricultural professions was often restricted. Zhao Erfeng's vision was not for Kham to become like the Manchuria of his own era. Several factors shaped his policy; the need to provision troops was important but should not be exaggerated. Also significant were a distrust of mobile labour and the traditional late imperial belief that the expansion of cultivation was the best thing a government could do to foster economic growth.

Zhao was more optimistic than his predecessors that substantial farming communities could be established in Kham, but Ren Naiqiang's later judgment that his settlement schemes were founded on unrealistic ideas about the Kham environment was somewhat unfair. Zhao's urge to control migration was also rooted in part in a recognition that many places in the region really were unsuitable for the establishment of crop-growing communities. He did not tend to acknowledge this in communications with the central government and prospective settlers, however. This was possibly the reason that some people in the interior held beliefs about the transformability of the frontier environment that really could be called “unscientific fantasies”.

${ }^{143}$ Quoted in Ibid. 
Philip Kuhn's interpretation of Wei Yuan 魏源 (1794-1856) is that he "was born into the relative sanity of the premodern age: government could not hope to achieve a fundamental transformation of human nature.”144 Though Zhao Erfeng was a couple of generations after Wei Yuan, a similar comment could be made of his attitude toward frontier agriculture: it would be wrong to connect it to the Maoist utopian hope that grasslands could be transformed into cornfields. Yet if Zhao's strategy lacked the visionary excess of Maoist frontier agriculture, it lacked other kinds of vision as well. Efforts to gather more knowledge about frontier ecologies and the kinds of food that could be produced in them were very limited. Zhao disapproved of La Shijun's proposed experiments with a wide range of crops, and did not attempt to gather information about livestock farming as the Xinjiang administrations of his own time did. Zhao also appears never to have seriously questioned the assumption that the expanding cultivation was the best investment the administration could make in frontier development, as a couple of his officials did.

By 1911, some settlements had been established, but progress was disappointing. It is hard to say how Zhao Erfeng would have responded had he had more time. Many of his officials fared better than Zhao in the Revolution, and there were strong continuities as well as differences between the Qing and Republican periods. The way that Republican period policy evolved, both in response to the challenges of that era, and the unresolved problems facing the Qing plan is the major question of the following chapter.

\footnotetext{
${ }^{144}$ Philip A. Kuhn, Origins of the Modern Chinese State (Stanford: Stanford University Press, 2002), 50.
} 


\section{Chapter three: Continuity and Change in the Republican Period}

As we saw in chapter one, Han local and regional state authority experienced a decline between approximately 1917 and the mid-1920s. It recovered after this, thanks to subsidies from the national and Sichuan governments, opium export, Liu Wenhui's willingness to commit resources to the region before 1933, and his having no choice about doing so after then. Thus there were two periods in which the Chinese highland state was relatively strong in some locations, separated by an interregnum of weakness that lasted around a decade. The primary question in this chapter is how similar regional government in the two eras of relative strength was. In terms of its character and policy, did the Liu Wenhui regime essentially represent a revival of the Zhao Erfeng administration? Many of the laws and administrative customs that Zhao created remained in place throughout the Republican period. Liu's regime was also ostensibly committed to many of the goals that Zhao had pursued. We saw in chapter one that the late Qing government had prioritized Kham over Ningyuan in its allocation of resources, and this bias remained also more or less ingrained in the Republican period. However, there were also some considerable differences in policy. Liu's government moved away from Zhao Erfeng's emphasis on fostering communities of crop-growers who were tenants of the state but independent of each other. Instead, late Republican policy was to create large state-owned agricultural enterprises that in many cases did not have crop growing as their core purpose. Another key point of divergence was policy regarding huang land ("wasteland”). The Xikang provincial authorities continued to proclaim state ownership over huang land, but not only was this principle not enforced by local governments, but even provincial government enterprises rented huang land from private owners. This chapter explores potential causes for these shifts, and argues that one decisive factor was the shift in the relative importance of different forms of taxation for local governments. 


\section{Qing-Republican Continuities}

There was disagreement among Han engaged with the frontier about Zhao Erfeng's rule, and particularly how it was remembered by indigenous people. Chen Zhongsheng wrote:

Not for nothing do the Tibetans [Fan 番] view Zhao as a 'butcher' [...]. In the winter of 1911, Zhao died dishonourably when he was beheaded in Chengdu. It was a fitting end. ${ }^{1}$

Other writers gave almost diametrically opposite views. An article in Chuanbian Quarterly summarized his achievements thus:

Today when the people of Xikang talk of Zhao Erfeng they are fearful, respectful and desirous of his return; his memory is loved and cherished. Truly, such men are exceptionally rare among frontier officialdom. ${ }^{2}$

Liu Wenhui's view was somewhere in between the hagiography and condemnation. He wrote that Zhao had "exerted himself with great diligence” but that his policy had "not escaped extremism”. ${ }^{3}$

Despite such reservations about certain aspects of Zhao's approach, Republican period regulations relating to land and ownership left the system bequeathed to them by the Qing largely intact. The theory that huang land was government owned and that farmers who reclaimed it were tenants of the state existed until the end of the Republican period. When Xikang province was established in 1939, the new provincial authority drafted a series of “Land Rights Principles (di quan yuanze 地權原則)”. An article on the principles in Chuanbian Economy Quarterly approvingly pointed out

\footnotetext{
${ }^{1}$ Chen Zhongsheng 陳重生, Xi xing yan yi ji 西行豊真異記 (Shanghai: Shanghai shibao, 1930), 191-93.

2 ZYDZ, "Diaocha ziliao," Chuanbian jikan 1, no. 3 (1935): 179.

3 JKDZ, 75.
} 
that they were based on the precedent left by Zhao Erfeng. ${ }^{4}$ The "Land Rights Principles” were:

1) All forested land and wasteland is without exception considered public property

2) Pastoral land (mu di 牧地) shall be communally owned by groups of pastoralists.

3) Land cultivated by serfs (chaimin 差民) shall belong to the government according to established custom.

4) People who have cultivated plots of land for more than twenty years shall without exception receive full individual title (suo you quan 所有 權).

5) Publicly owned land shall be brought under cultivation according to regulations. Cultivators shall be recruited and granted five years before they are eligible to pay tax.

6) Arable wasteland that is occupied by tusi, shall be purchased at a regulated minimum price by the government and distributed among settlers (kenmin 墾民), or directly purchased by the settlers.

7) Occupiers or purchasers of wasteland who do not cultivate the land or rent it to tenants who do, shall pay a wasteland tax, which shall increase annually.

8) Regulations shall stipulate the maximum amount of wasteland that may be privately owned by an individual, in order to prevent emergence of large land owners. ${ }^{5}$

Evidently, there is some ambiguity here. The articles began with a straightforward declaration of the state's rights over wastelands. In number six, wasteland has to be purchased by the government from "occupiers". In number eight, private ownership of wasteland is permitted, albeit within certain as yet undefined limits and subject to undefined but menacing rates of taxation. The articles imply that pastoral land and huang land are different categories, yet some government institutions made pastoral land a subcategory of huang land. ${ }^{6}$ It seems implausible that the drafters of these principles had not noticed these problems, and the most likely explanation is that there was some amount of disagreement among them. Broadly,

\footnotetext{
${ }^{4}$ Tu Zhongshan 涂仲善, "Tiaozheng Kang qu di quan wenti zhi guan jian 調整康區地權問 題之管見," Xikang jingji jikan 西康經濟季刊 1, no. 8 (1944): 63.

${ }^{5}$ Ibid.

${ }^{6}$ See Xikang sheng nongye gaijin suo 西康省農業改進所, "Xikang sheng tudi hukou diaochabiao 西康省土地戶口調查表," 1947, (SCDAG, QZH: 249, AJH: 152).
} 
however, the principles indicated that the government would take an aggressive, appropriative stance toward developing wasteland, reminiscent of that taken by Zhao Erfeng.

Other proclamations and plans did not always go as far as the first article in the above principles, but nevertheless sketched measures to be taken against the owners of forested or huang land. A resolution passed by the Xikang Provincial Assembly stated "the government shall require all private owners of huang land to cultivate it within a certain limited period of time. If they do not, people who need land may apply to appropriate it according to the law."7 The Xikang Agriculture Improvement Institute (Xikang sheng nongye gaijinsuo 西康省農業改進所, henceforth 'Agriculture Institute'), founded in 1939, drew up a plan for the development of a proposed forestry zone (yinglin qu 營林區) in Ningshu. ${ }^{8}$ The Agriculture Institute envisaged that the area chosen would consist mostly of huang land, which would mostly be already public land. Several principles were formulated to deal with any private land (min di 民地) that the zone might also contain. Plots of less than $100 \mathrm{mu}$ would be appropriated by the government, and the owners given as compensation 30 percent of the gross profit from the trees that the Agriculture Institute would plant on their plots. Owners of more than $100 \mathrm{mu}$ could keep their land, but would have to use it for forestry according to the Agriculture Institute plan. In 1947, the Draft Xikang Gazetteer (Xikang tong zhi gao 西康通志稿) stated that “Apart from in a part of southern Kham where there is buying, selling and conditional-selling (diandang 典当) ${ }^{9}$ of land, the rest of the land is publicly owned (gongyou 公 有). Huang land may be rented by the people from the government.”10

\footnotetext{
${ }^{7}$ Xikang sheng canyihui 西康省參議會, "Linshi canyihui, di yi ci hui huibian 臨時參議會 第一次會匯編," 1940, (SCDAG, QZH:204, AJH:14), section 8, p.9.

${ }^{8}$ Xikang sheng nongye gaijin suo, "Xikang sheng Ningshu senlin shiwusuo ying lin huading banfa 西康省寧屬森林事務所營林劃定辦法," 1940, (SCDAG, QZH:249, AJH:79).

9 "Conditional sale": farmers who did this retained the right to lease the land from the person to whom they conditionally sold it, as well as the right to buy it back. See Philip C. C. Huang, Code, Custom and Legal Practice in China: The Qing and the Republic Compared, (Stanford: Stanford University Press, 2001), chapters 3, 5.
}

${ }^{10} \mathrm{JKDZ}, 80$. 
The basic elements of Zhao's settlement system also survived in the Republican period, though the system was more often implemented by semi-private companies than state authorities. The Republican period saw the establishment of several settlement "societies" (she 社), and “companies” (gongsi 公司), mostly by men with official positions or ties. In Kangding, for example, in 1934 Deng Pancun 鄧蟠村, a Twenty Fourth Army colonel, and Chen Dongfu 陳東府, the Administration Department director, founded the Golden Abundance Crop and Pasture Company (Jin bo ken mu gongsi 金博垦牧公司), intending to develop a range of agriculture and forestry businesses. ${ }^{11}$ Companies such as these tended to adopt very similar systems to that which Zhao had created. In 1934 the Sichuan Construction Bureau (jianshe ting 建設廳) reported on the Pioneer Cultivation Society (tuo bian ken she 拓邊墾社, henceforth Pioneer Society), which was working in Mabian. As with the Qing system, new settlers were required to report to Pioneer Society and, if accepted, given the official status of “cultivating household” (ken $h u$ 䇝戶). ${ }^{12}$ On the basis of an assessment of the settler's ability, the Society assigned them areas of land, and granted interest-free loans of food, agricultural equipment and seeds if settlers were unable to provide these things for themselves. As the imperial state had done, the Society retained ultimate ownership of all the land worked by its cultivating households, withholding from them the right to buy and sell land. Indeed, it played an even larger role in the management of social and economic activity in the community than Zhao Erfeng's government had done in the settlements it founded. 'Cultivating households' did not pay taxes to the Pioneer Society, and instead they performed labour duties, such as building roads, defences and other public works. ${ }^{13}$ Thus, at the same time that in northern China traditional labour duties owed by peasants were being converted into cash payments, and other Xikang governors were trying to convert the wula corvée system into a system of

\footnotetext{
${ }^{11}$ Sichuan nongye 四川農業, 1:11/12 (1934): 112-113.

${ }^{12}$ ZYDZ, "Diaocha ziliao," Chuanbian jikan 1, no. 2 (1935): 139-42.

${ }^{13}$ Ibid.: 141.
} 
paid labour (see chapter four), a “modernizing” settlement society adopted a system of taxation via unpaid labour. ${ }^{14}$ The Pioneer Society also managed community education, public enterprises, entertainment, marriage and funeral ceremonies, and had detailed conduct rules for the registered households. In the economic sphere, it ran a market where the Han settlers could trade with local Yi, although the Sichuan Frontier Quarterly report implied this was unnecessary because everything that the settlers needed was already provided by the society.

As we saw in the previous chapters, the Qing engagement with the Sichuan frontier was characterized by a bias towards Kham over Ningyuan. Ren Naiqiang was fiercely critical of this, and made the comparative advantage argument to support his view that Xikang should be developed as a united whole in which each component region would receive funding to promote whatever it was best suited to. Having excoriated the decision to focus on grain production in Kham, Ren proposed the following alternative:

Fortunately, bordering Kham, Sichuan and Yunnan are the eight counties of Ningyuan, which are well suited to the production of grain. [...] Currently polished rice costs seven jiao per sheng in Kangding, but in Xichang, Mianning and other Ningyuan counties, one can buy a dou with half a yuan [i.e. five jiao for 10 sheng of rice]. The reason for this difference is that the former place is reliant on far away sources of food, while the latter place has no way to export its produce. There is now a national consensus in favour of the unification of Kham and Ning into one province. [...] A highway between Ning and Kham can be swiftly completed with the concentration of the resourses of the new province. In the future, there will be much improved availability of grain in Kham and animal produce in Ning. [...] For this reason those involved with crop production must focus on the eight counties of Ning. [...] If Kham strives for food self-sufficiency, even if pure gold were spent as though it were manure, and flesh and blood used to irrigate the soil, there would still be no profit. ${ }^{15}$

\footnotetext{
${ }^{14}$ Prasenjit Duara, Culture, Power, and the State: Rural North China, 1900-1942 (Stanford: Stanford University Press, 1988), 78.

${ }^{15}$ Ren Naiqiang, "Xikang yuncang de fu li yu jianshe de tujing 西康緧藏的富力與建設的 途徑," Xibei wenti jikan 西北問題季刊 2, no. 1 (1936): 59.
} 
These ideas met with approval at the very highest levels of the Xikang government. In his 1939 address at the establishment of the province, Liu Wenhui commented that "the climate, soil, produce and population distribution in the Ning region is especially advantageous [for agricultural development programs]”. ${ }^{16}$ And between 1939 and 1942, government spending on the Agriculture Institute projects was divided roughly evenly between Kham, Ningshu and Yashu. ${ }^{17}$

However, Ren Naiqiang's vision of a unified agricultural development strategy for the whole of the highlands was never fully realized, and nor did it lead to a correction of the government's focus on Kham outside agriculture. Firstly, although, the concentrated resources of the new province did indeed produce a flurry of road building, none of the major new roads connected Ningshu with Kham. Instead, 1941 saw the completion of new roads between Kangding and Ya'an, Xichang and Leshan and Xichang and Yunnan. ${ }^{18}$ In 1942 a road between Kangding and Kanze was finished. The Xichang-Leshan highway improved transport between Kangding and Ningshu, but it still left a substantial amount of ground to be covered on the older and much slower roads. It was a road building program that envisaged not one integrated frontier territory, as Ren had, but two frontier territories that were connected by different transport links to different parts of the outside world.

Secondly, although spending on agricultural projects was evenly divided between Xikang's three constituent regions, outside agriculture the provincial government spent much more per-capita on Kham, particularly in the Kangding-Luding region, than on Ningshu or Yashu. The choice of Kangding, rather than any of the half-dozen much larger towns in Yashu and Ningshu to be the provincial capital was a symptom, as much as a cause

\footnotetext{
${ }^{16} \mathrm{JKDZ}, 73$.

${ }^{17}$ Liu Yiyan 劉貽燕, "Wu nian lai Xikang nongye jianshe zhi huigu 五年來西康建設之回 顧," Xikang jingji jikan 1, no. 8 (1944): 5-6.

${ }^{18}$ Liu Jun 刘君, "Jian lun Xikang sheng 简论西康省," in Minguo dang'an yu minguo shi xueshu taolunhui lunwen ji 民国档案与民国史学术讨论会论文集, ed. Zhang Xianwen 张宪文, Chen Xingtang 陈兴唐, and Zheng Huixin 郑会欣 (Beijing: Dang'an chubanshe 1988), 328.
} 
of Kham-centricism. As figure one (below) illustrates, the volume of credit made available to cooperatives showed a strong bias towards Kangding and Luding. In the era of hyperinflation, credit at normal interest rates was essentially a gift. Bearing in mind that the population of both of these counties combined was probably only the size of Yuesui's, and much smaller than Ya'an's or Xichang's, a greater volume of money per head of population entered Kangding and Luding via the cooperatives than any other county.

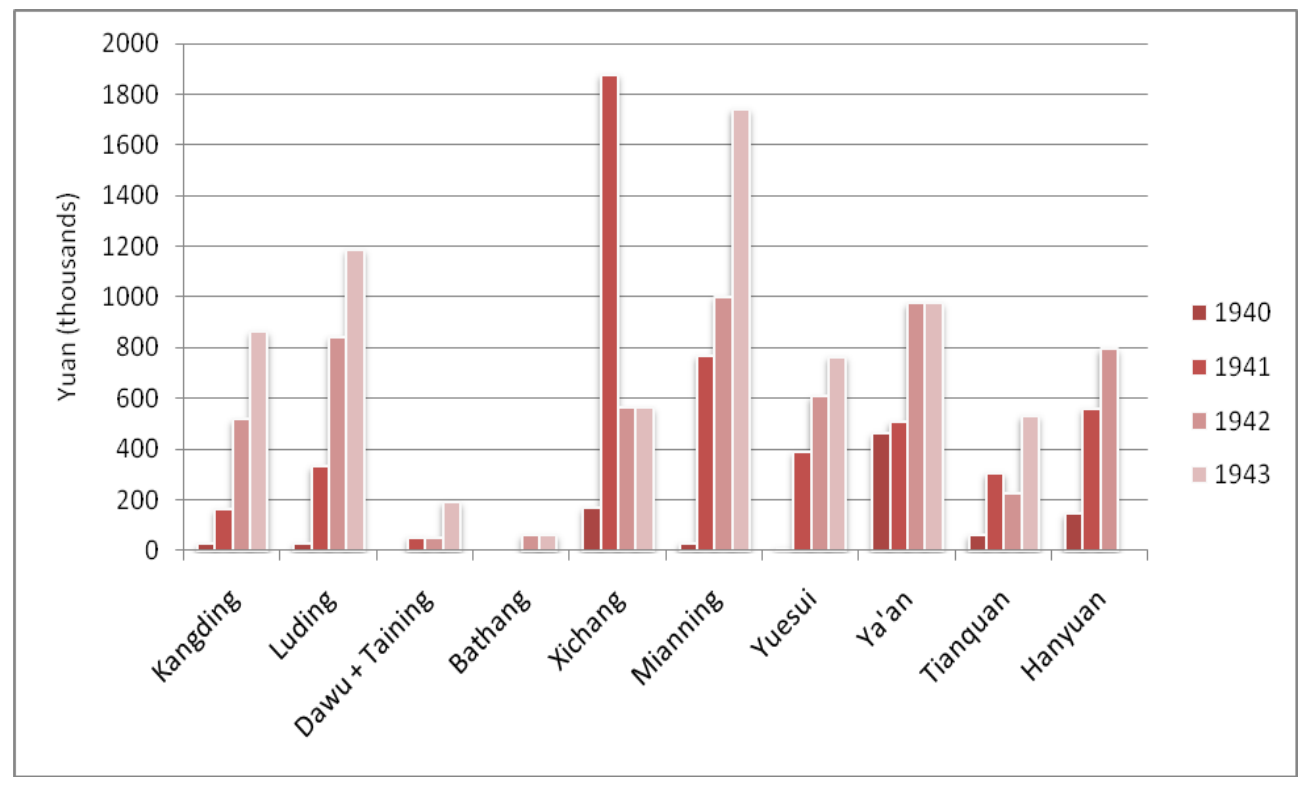

Figure one: Total County Cooperative Debt by Year. Source: Fiscal Records of Xikang Province (Jian sheng hou zhi Xikang caizheng 建省後之 西康財政). ${ }^{19}$

Education spending also offers a useful proxy for regional government engagement with a region and its population, even though it is often difficult to meaningfully interpret. To calculate spending in relation to population size we would need good population data, which is often absent for indigenous populations. This would not matter so much if we could safely assume that all government spending on education was directed toward the Han and mixed populations, for which there are more reliable counts. But

\footnotetext{
${ }^{19}$ Xikang sheng caizheng ting 西康省財政廳, Jian sheng hou zhi Xikang caizheng 建省後 之西康財政 (Kangding: Xikang sheng caizheng ting, 1945), chapter 11, pp. 16-26.
} 
given efforts to educate the indigenous population, this was not necessarily the case.

In 1939 government spending per school student was much higher on the eastern edge of Kham than in Ningshu or Yashu (see figure two below).

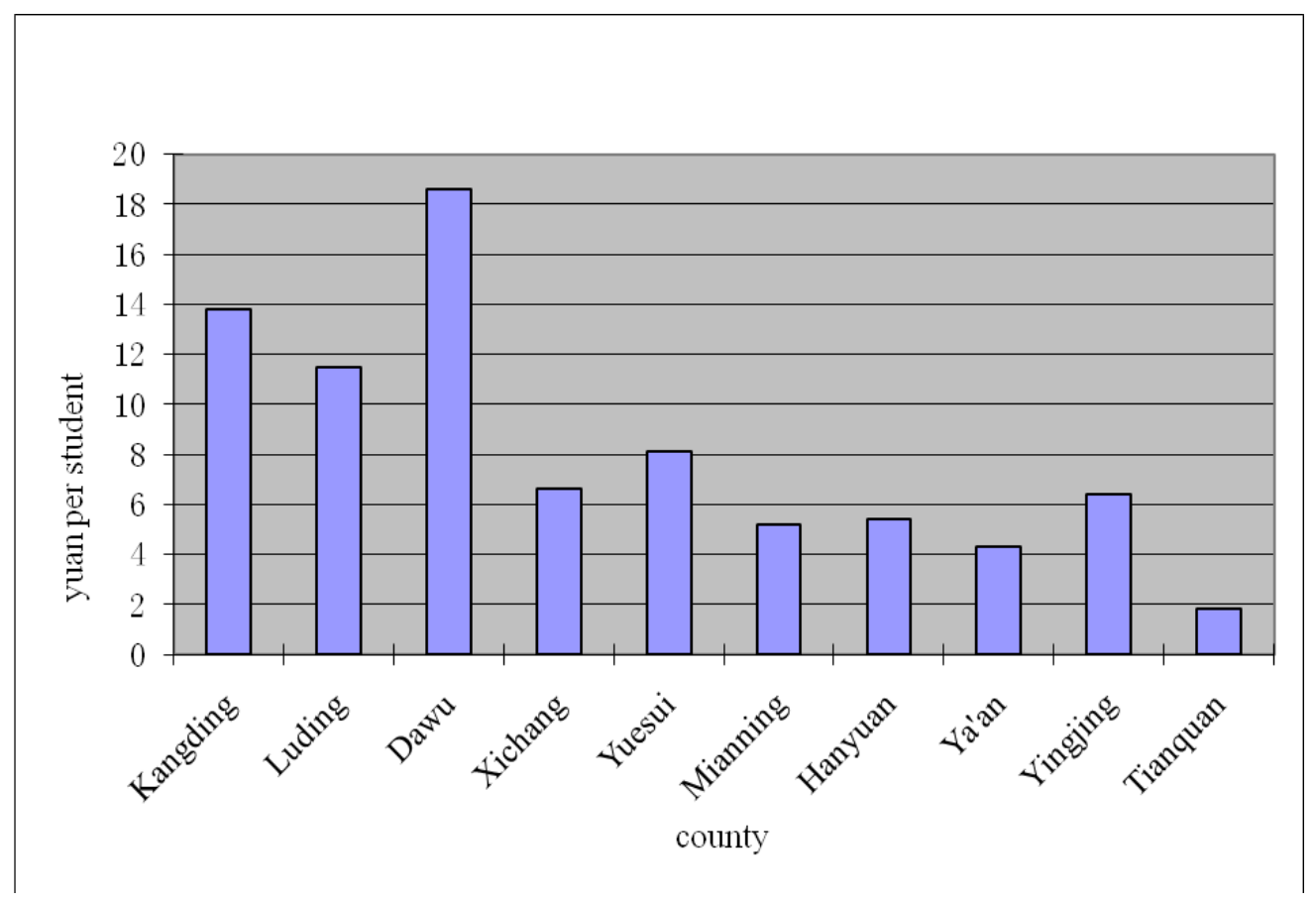

Figure two: 1939 government spending on education per enrolled student in selected Xikang counties. Source: $C K S B .{ }^{20}$

Spending per student should have been strongly influenced by the average number of students per class. Densely populated regions, like Yashu, could have larger class sizes, which would mean fewer teachers and buildings in relation to the number of students. In such conditions spending per student would be lower than in less densely populated regions like Kham. This explains the difference between Kham and Yashu well. But it does not account for the difference between Kham and Ningshu, because, unexpectedly, the number of students per education worker (jiaozhiyuan 教 職員, i.e. teachers and administrative staff) was roughly the same in Ningshu counties as it was in the eastern Kham (see figure three below). Therefore, the higher spending per student in eastern Kham compared with

${ }^{20}$ CKSB, 186, 192-93, 195-96, 467-68. 
Ningshu was not simply because Kham needed relatively more teachers per student because of a more dispersed population.

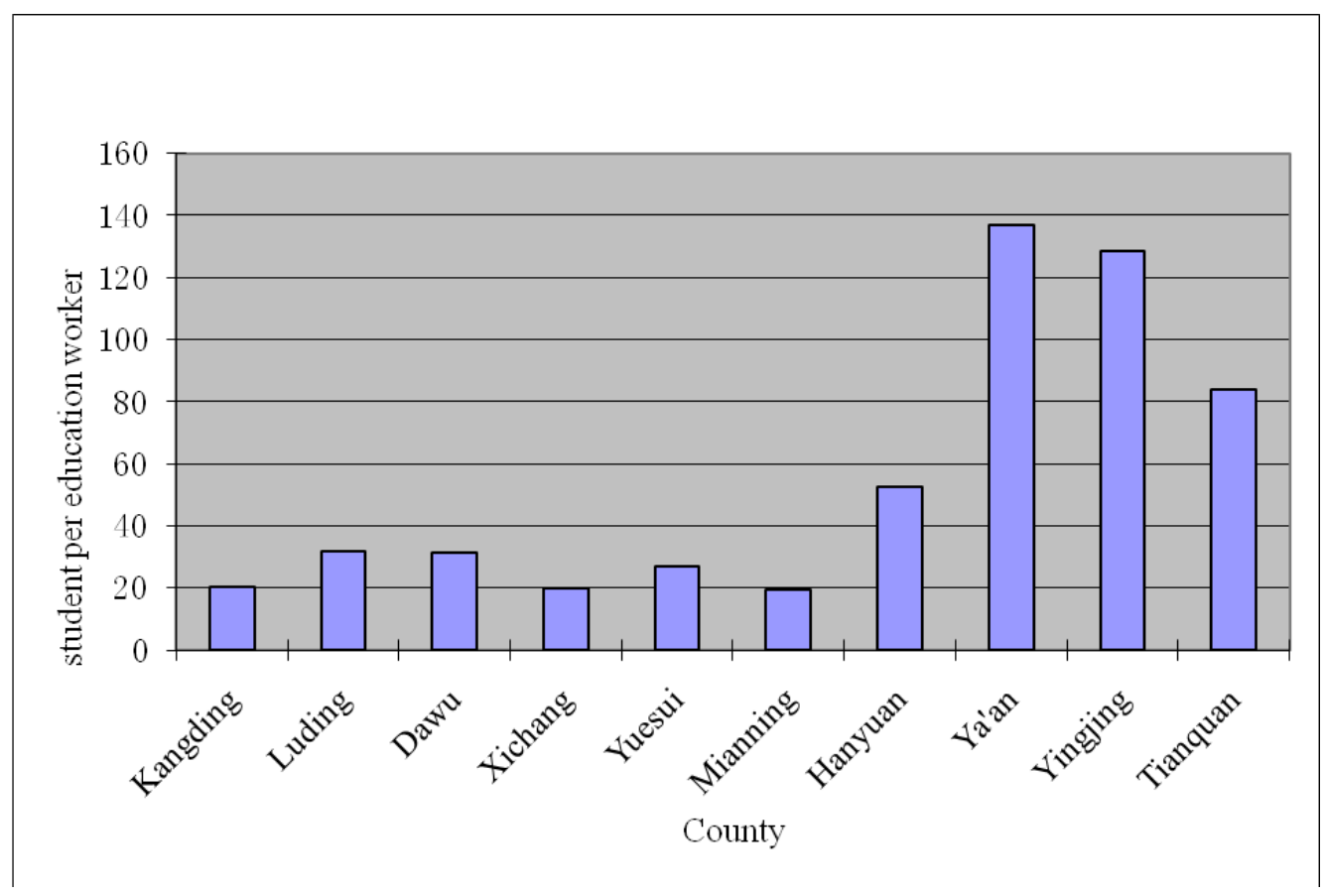

Figure three: Students per education worker in 1939 in selected Xikang counties Source: $C K S B .^{21}$

It is uncertain where the extra money went. Assuming that levels of corruption were roughly equivalent, it could have been used to pay higher salaries in Kham, or to make greater investments in school buildings and infrastructure in that region. As we shall see in the chapter four, wages in Kham were high in relation to other places, but the difference was not so great as to explain the gap seen in figure one. Alternatively, some of the difference may have been due to greater efforts to attract indigenous people to school. If those efforts were unsuccessful, then overall costs in relation to student numbers would have been higher. Just as the regional government prioritized eastern Kham in its loans to cooperatives and its industrial projects, its spending in education was similarly skewed towards that region. In addition to the maintenance of theoretical state ownership over huang

${ }^{21}$ Ibid. 
land, and the societies that implemented Zhao Erfeng-ist settlement systems, this was another area in which the late Republican state followed the pattern of its late Qing predecessor.

\section{Changes in Policy on Land and Agriculture}

Despite the similarities detailed above between the Liu Wenhui and Zhao Erfeng regimes, there were some very significant differences. The biggest concerned their agricultural development strategies and attitude toward actually appropriating the huang land that the state theoretically owned.

In the 1930s, the regional government's agricultural spending was concentrated on establishing experimental farms in Kham and on an operation to raise livestock for the government to use as pack-animals, discussed in chapter four. ${ }^{22}$ After 1939, funding for agricultural development went through the Agriculture Institute. The main focus of the Institute's activity was a series of state-owned enterprises that were either newly founded or built on the 1930s ventures. ${ }^{23}$ In Kham it operated a ranch (muchang 牧場) in Taining; a farm (nongchang 農場) in Simaqiao; a dairy farm (runiu chang 乳牛場) in Kangding; a forest and horticulture plantation (senlin yuanyi chang 森林園藝場) in Luding; and a fertilizer plant in Kangding. ${ }^{24}$ In Yashu, the Institute set up a farm in Ya'an, a sericulture operation (canchang 䖯場) in Hanyuan and a forest plantation in Tianquan. Ningshu enterprises were run through a regional office, which managed farms at Xichang, Dechang and Huili, nurseries at Mianning and Yanyuan

\footnotetext{
${ }^{22}$ On the experimental farms, see Wang Chuan, "Minguo hou qi "Xikang sheng nongye gaijin suo" de sheli shimo ji qi lishi yiyi 民国后期“西康省农业改进所”的设立始末及其 历史意义," Xizang daxue xuebao 西藏大学学报 20, no. 1 (2005): 61.

${ }^{23}$ Liu Yiyan, "Wu nian lai Xikang nongye jianshe zhi huigu," 5.

${ }^{24}$ See Ibid., also the provincial government budgets in Xikang sheng canyihui, "Linshi canyihui, di san ci hui huibian 臨時參議會第三次會匯編," 1942, (SCDAG, QZH: 204, AJH: 16), pp.77b-79a. Wang Chuan, "Qing mo, Minguo shiqi Xikang diqu de nongye gaijin ji qi shiji chengxiao 清末、民国时期西康地区的农业改进及其实际成效," Minguo Dang'an 民国档案, no. 4 (2004): 56.
} 
and a silk reeling factory at Lizhou. The Institute also established a series of weather and climate monitoring stations throughout the new province.

Liu Wenhui's provincial government made significant efforts to recruit outside talent for the Institute. The vice-director, Xu Xiaohui 徐孝恢, was a graduate of the agriculture program of Tokyo Imperial University. ${ }^{25}$ The first director was Ye Xiufeng 叶秀峰, who was concurrently the director of the Xikang Construction Bureau. ${ }^{26}$ Ye was a Jiangsu native, a graduate of Princeton University and a member of the Guomindang. He was therefore something of an outsider in Liu Wenhui's administration. There are reports that he and Liu disagreed on various matters which is probably why Ye left after a couple of years. ${ }^{27}$

None of the Agriculture Institute enterprises appear to have been regarded as outstanding successes. Established during wartime, they were not well resourced. Moreover, they suffered from being tasked with pursuing multiple, potentially conflicting aims. They were supposed to conduct research into improving animal and plant stocks, educate the natives in agricultural techniques, run profitable businesses, and at the same time bring more land into use. ${ }^{28}$

Overall, there were two fundamental differences between the Xikang provincial government's agricultural strategy and Zhao Erfeng's. The two governments promoted different organizational forms and, in many cases, pursued different kinds of agricultural activity. The late Qing administration had attempted to foster settlement by independent state-tenants who would grow crops and manage separate plots of land to which they would have permanent use rights. The Xikang provincial government-owned enterprises

\footnotetext{
${ }^{25}$ Wang Chuan, "Minguo houqi "Xikang sheng nongye gaijin suo" de sheli shimo ji qi lishi yiyi," 62.

${ }^{26}$ Wang De'an 王德安, "Jiefang qian Xikang jianshe ting ji jingji jianshe gaikuang 解放前 西康建设厅及经济建设概况," in Ya'an wenshi ziliao xuanji: di ba ji 雅安文史资料选辑 : 第八辑, ed. Zhongguo renmin zhengzhi xieshang huiyi Sichuan sheng Ya'an shi weiyuanhui 中国人民政治协商会议四川省雅安市委员会 (Ya'an: Zhongguo renmin zhengzhi xieshang huiyi Sichuan sheng Ya'an shi weiyuanhui, 1994), 67. Wang Chuan, 'Minguo houqi "Xikang sheng nongye gaijin suo’," 63.

${ }^{27}$ Wang De'an, "Jiefang qian Xikang jianshe ting ji jingji jianshe gaikuang," 68.

${ }^{28}$ See Wang Chuan, "Minguo houqi 'Xikang sheng nongye gaijin suo’."
} 
did rent a very small amount of land to independent tenants. ${ }^{29}$ But generally they employed people as waged labourers. A document relating to the establishment of a farm at Simaqiao stated that:

Farmers on cultivated land [to be acquired by the farm] should be employed on preferential terms (congyou 從優) by the Agriculture Institute as agricultural workers (nonggong 農工). Those who do not wish to stay should be allowed to leave. ${ }^{30}$

One writer notes that workers tasked with crop-growing at Taining were given one yuan per ten days per 100 square meters they cultivated. ${ }^{31}$

In addition to this substantial change in organizational form, a much broader array of projects received state support. Gone was the old emphasis on grain production. This was partly due to the influence of those like Ren Naiqiang, then a member of the Preparatory Committee of Xikang Province, who believed that past schemes had been "unscientific fantasies" because they had not considered what kinds of activities were really suited to the Xikang environment. ${ }^{32}$ The emphasis on education of indigenous people in what were considered to be better agricultural techniques was also a strategy advocated on the grounds that it was a more "realistic" approach to agricultural development. ${ }^{33}$ In Kham, the shift towards livestock farming was also due to the wula crisis of the Republican period, which we shall examine in the next chapter.

Probably due to the differences in organizational form and range of projects they pursued, there was a further difference between the Zhao Erfeng and Liu Wenhui administrations in how the results of agricultural

${ }^{29}$ At the Simaqiao farm, $26 \mathrm{mu}$ out of the farm's $536 \mathrm{mu}$ was rented to private tenants. Simaqiao nongchang changzhang 司馬橋農場場長, correspondence with Director of Agriculture Institute, 1943, (SCDAG, QZH:249; AJH:81).

${ }^{30}$ Xikang sheng nongye gaijinsuo, "Zhengyong Simaqiao nongchang jingguo 征用駆馬橋 農場經過", 1940, (SCDAG, QZH:249; AJH:81).

${ }^{31}$ Dao Xue 稻雪, "Xikang Taining shiyanqu diaocha 西康泰宁试验区调查," Xin Kang bao 新康报 1, no. 2 (1938). In Zhao Xinyu and Qin Heping, eds., Kangqu Zangzu shehui lishi diaocha ziliao jiyao (Chengdu: Sichuan minzu chubanshe, 2004), 214.

${ }^{32}$ Ren Naiqiang, "Xikang yuncang de fu li yu jianshe de tujing," 53.

${ }^{33}$ CKSB, 402-03. 
policy were assessed. The late Qing government had been strongly focused on the number of migrants who came to the frontier and the number of $m u$ that they brought under cultivation, though as we saw in chapter two, officials' reports of cultivated $m u$ were often fairly haphazard. For the Agriculture Institute, volume of output; the number of shi of grain, dan of cotton, or pounds of butter (as well as cultivated land area) constituted the relevant measures of success or failure.

The state farms were not in all respects a break from the precedent established by Zhao Erfeng. In some ways, their innovations intensified rather than moved away from the characteristics of the late Qing agricultural policy. The Qing regime had played a strong role in the management of migrant communities, and the new organizational form of waged labour allowed this to be taken to new heights. The vice-director-general of the Taining farm conducted daily literacy and cleanliness activities, and a weekly 'mass training' session. The farm also ran consumers' cooperatives (xiaofei hezuoshe 消费合作社) to provide for its workers.

Huang land in practice

The other major difference between the Liu Wenhui and Zhao Erfeng periods concerned the status of huang land. As we saw above, Liu's government maintained the theoretical position that huang land belonged to the state (though in some instances it allowed a certain amount of ambiguity to creep into regulations). In practice, this theoretical state ownership of huang land was almost never recognized and even the Agriculture Institute enterprises rented huang land from private owners. Zhao Erfeng's administration had not always been able to actually enforce meaningful state ownership over land it categorized as huang. But the late Republican government appears to have made almost no effort whatsoever to do so.

In 1936 an aggrieved member of the Bank of China research group wrote a bitter tirade against the Kangding local authorities for Sichuan Frontier Quarterly. They had "betrayed the Three Principles of the People and 
violated national law.” ${ }^{34}$ The crime of the local government was to allow local Tibetan households the right to charge Han Chinese settlers rent for the privilege of using huang land that the Tibetans claimed to own. ${ }^{35}$ To ram home his attack the writer highlighted the case of a man who was forced to pay rent to bury his wife on a huang hillside. There were many aspects of the case that caused outrage. The rent was "ten times higher than in Shanghai" (which is quite hard to believe). The land "owners" allegedly robbed and murdered people who did not pay up. It was said they did not pay taxes on their land. They sold the land to foreigners who used it to start colonies. But the core problem was with the very idea that this type of land could be privately owned. "Huang land like this, according to regulations in the president's Fundamentals of National Reconstruction (jianguo dagang 建國大綱) 'belongs to local governments, and must be used for local enterprises for the public good'.” ${ }^{36}$ By rights, it was "national, publicly owned huang land.”

But it was not only poor Han migrants who paid private individuals rent for the use of huang land. With the exception of the ranch at Taining, which was special for reasons made apparent in chapter four, state-owned enterprises established by the Agriculture Institute rented the land they used from private landowners, even when the land was registered as wasteland or forest. The huang land used by Kangding's Simaqiao farm was all rented, from a Catholic mission, the Wasi Tibetan household (the same family whose rent-a-gravesite practices had enraged the Bank of China's researcher), and other landlords of uncertain ethnicity. ${ }^{37}$ This was not merely a Kham phenomenon. In a letter to Liu Wenhui in 1944, the Agriculture Institute's Ningshu office reported that the Ningshu agricultural and forestry enterprises "have never owned any of their land. It is all

\footnotetext{
${ }^{34}$ ZYDZ, "Diaocha ziliao," Chuanbian jikan 川邊季刊 2, no. 2 (1936): 163.

${ }^{35}$ Ibid.: $162-63$.

${ }^{36}$ Ibid.: 162.

37 "Xikang sheng nongye gaijin suo xiang Simaqiao dizhu Wasi diao zujie Simaqiao tudi wei nongshi shiyanchang dang ping Kangding xian zhengfu ding heyue 西康省農業改進 所向䭾馬橋地主瓦司碉租借騳馬橋土地為農事試驗場當憑康定縣政府訂定合約 ,"1943, (SCDAG, QZH: 249; AJH: 81).
} 
rented”. ${ }^{38}$ The manager of the Ya'an farm wrote to the Agriculture Institute head office, stating that "since this farm has been established, all its land has been rented from private individuals.” 39 The manager asked the government to consider buying $140 \mathrm{mu}$ of land, most of which was marked as huang or "uncultivated" on the map sent with the request. The Xikang provincial government did expropriate small amounts of (cultivated and uncultivated) land for infrastructure projects like the Kangding airstrip. However, I have not encountered any evidence that the state expropriated land as the implementation of its declared principle that all huang land was public property. A detailed 1939 survey of huang land in Ningshu counties noted whether plots were owned by $\mathrm{Yi}$, Han private individuals, tusi, or the state (guan 官). ${ }^{40}$ In each county, the proportion of huang land that was stateowned was tiny. In Mianning, for example, five percent of the 242 square $l i$ of huang land in the county belonged to the state (and 55 percent was privately owned by Han).

The rent payments made by the state enterprises were quite low. The Simaqiao farm paid the Catholics, the Tibetans and the other landlords the uniform rate of eight $\mathrm{kg}$ of grain per $m u$, and "in accordance with local custom” the government did not pay any rent for the first three years. ${ }^{41}$ According to Dwight Perkins' figures, the Republican period national average per mu yield of barley was around $75 \mathrm{~kg}$; so if the Simaqaio land had produced this much, rent would have amounted to only a bit more than ten percent of yield. ${ }^{42}$ But in reality only a small proportion of the farm's

\footnotetext{
${ }^{38}$ Xikang sheng nongye gaijin suo, Ningshu ban'gong shi shizhang Xu Xiaohui 西康省農 改所, 甯屬辦公室室長徐孝恢, correspondence with Director of Agriculture Institute, 1944, (SCDAG, QZH: 249; AJH: 79).

${ }^{39}$ Xikang sheng nongye gaijin suo, Ya’an nongchang changzhang 雅安農場場長, correspondence with Director of Agriculture Institute, 1947, (SCDAG, QZH: 249; AJH: 79).

40 "Ningshu diaocha baogao huibian," nongmumen 農牧門, 67-77.

41 "Xikang sheng nongye gaijin suo xiang Simaqiao dizhu Wasi diao zujie Simaqiao tudi wei nongshi shiyanchang dang ping Kangding xian zhengfu ding heyue 西康省農業改進 所向駆馬橋地主瓦司碉租借馮馬橋土地為農事試驗場當憑康定縣政府訂定合約," 1943, (SCDAG, QZH: 249; AJH: 81)

${ }^{42}$ Dwight H. Perkins, Agricultural Development in China, 1368-1968 (Edinburgh: Edinburgh University Press, 1969), 279.
} 
land was productive at that level. In 1949, the manager of the Simaqiao farm reported that of the $536 \mathrm{mu}$ they had rented only a little more than $100 \mathrm{mu}$ had been cultivated. ${ }^{43}$ The manager did not state how much the farm earned from this and the livestock that presumably grazed on at least some of the uncultivated land. But however much the farm made, "after paying the rent there is very little left. If the weather is dry, output drops significantly and self-sufficiency is very difficult.” ${ }^{44}$

Most of the other farms were much smaller than this one (again, with the exception of the Taining ranch), and understandably so. If the government policy was to rent rather than expropriate huang land, there was no point in adding to expenses by renting large amounts of land when it was uncertain whether it could be put into profitable production or not. The contrast with Zhao Erfeng's approach is stark. After the central government had paid Zhao's military expenses, it had cost nothing for him to appropriate huang land in the name of the Emperor with the aspiration of filling it with as many settlers as possible, who were permitted free use of as much of it as their strength permitted. There was not much chance that the late Republican local governments would be so generous given that huang land was something they rented from private owners, rather than something they acquired for free. In Yashu and Ningshu, where rent was more expensive than in Kham, some enterprises experienced a serious shortage of land. ${ }^{45}$ The Ya'an farm had $40 \mathrm{mu}$; 10 of which was devoted to experimental crops and 30 to production for the market in an unsuccessful effort to recoup expenses. The Hanyuan farm did not have enough land to establish a

\footnotetext{
43 "Xikang sheng nongye gaijin suo Kangding nongchang yewu gaikuang 西康省農業改進 所康定農場業務概況," 1949, (SCDAG, QZH: 249; AJH: 152).

${ }^{44}$ Ibid.

${ }^{45}$ For example, a Dechang farm and forest plantation paid one landlord two shi for $12 \mathrm{mu}$, nearly double the Simaqiao farm's rents. Generally, agriculture is more productive in Ningshu due to the warmer climate. However, with higher rents, the cost of not producing anything, or producing inefficiently would have been higher.
} 
mulberry plantation, even though silk production was one of its core activities. ${ }^{46}$ It had to buy its mulberry leaves from private growers.

In addition to not enforcing theoretical state ownership of huang land even when the vital interests of state agricultural enterprises were at stake, no punitive measures were ever taken against landlords who owned wasteland. In fact, such land was either not taxed at all, or taxed at a rate far below other categories of land. In Hanyuan in 1940, all land was categorized into nine grades depending on its productivity. Huang land was in the bottom category, and taxed at a rate that was only one eighth of the category that contained the worst kind of tian $⿴ 囗 十$ “field” land. ${ }^{47}$

The decision to rent huang land rather than expropriate it seems to represent an unexpected bout of respect for private property from what Barnett calls "one of the most oppressive (in my opinion, one of the worst) warlord regimes in China." ${ }^{48}$ It had far reaching consequences for the model of agricultural development employed by the government enterprises. It probably also affected private land reclamation as well. The 1936 Sichuan Frontier Quarterly article quoted above argued that:

For more than twenty years the government has attempted to foster migration to the Kham borderlands and the cultivation of its huang lands, but they have made no progress whatsoever. Efforts have been obstructed by the evil influence of vestiges of feudalism. ${ }^{49}$

Describing ownership of huang land as "feudalism" was stretching the definition of "feudalism", even by the standards of Chinese discourse in which the concept stood for a vague array of problematic conditions. Nevertheless, in arguing that this restricted settlement the writer had a point.

\footnotetext{
${ }^{46}$ Xikang sheng nongye gaijin suo. Hanyuan nong chang changzhang 漢源農場場長, correspondence with Director of Agriculture Institute, 1947, (SCDAG, QZH:249, AJH: $101)$.

${ }^{47}$ Xikang sheng tudi chenbao banshichu 西康省土地陳報辦事處, "Hanyuan xian di mu shuilü fu'e tongji biao 漢源縣地㽞稅率賦額統計表," 1940, (SCDAG, QZH: 248, AJH: 2).

${ }^{48}$ A. Doak Barnett, China's Far West: Four Decades of Change (Boulder: Westview Press, 1993), 448.

${ }^{49}$ ZYDZ, "Diaocha ziliao," Chuanbian jikan 2, no. 2 (1936): 163.
} 
As we shall see in chapter six, the high cost of transport in the frontier meant that away from major markets farming could only be profitable if farmers had virtually free use of land.

Why did Republican governments allow people to exercise private ownership over huang land, a course that was detrimental to both their own agricultural enterprises and the general ambition of increasing Han settlement in the highlands? As we saw in chapter one, although the late Republican regional government only controlled a small part of the territory it claimed, within this zone of control its authority was relatively strong. In 1939, Liu Wenhui's Twenty Fourth Army defeated the well armed field office of the Panchen Lama in distant Kanze in only two months (see chapter four). It would be wrong to think that the army was simply not strong enough to confiscate plots of huang land for the provincial government's agricultural enterprises. Rather, this was a result of structural factors relating to the state's methods of raising revenue, as well as the landowning interests of some (but not all) government officials' families and their peers.

\section{Government by Official-Elite Network?}

The most popular explanation in the Republican period for governments' failures to allow settlers free use of huang land was that wealthy landowners bought off local authorities. This is the explanation given in the Sichuan Frontier Quarterly article quoted above, which accused the Kangding authorities of taking bribes from Tibetan families in return for allowing them to collect rent from Han users of huang land. This has also been the explanation that other scholars have highlighted when discussing analogous phenomenon in the Sichuan basin. Referring to a book about Sichuan's Republican-period malaise, Robert Kapp writes:

Landowners, if they wished to escape the ruinous demands of bandits, militia and occupying armies had to be on good terms with the predators 
and be able to buy their good will with flattery, gifts, and lavish entertainment. ${ }^{50}$

Here we are presented with suffering landlords who were forced to bribe rapacious men-at-arms, rather than rapacious (Tibetan) landlords who bribed (negligent) men-at-arms, causing migrants (who were apparently absent from the Sichuan basin scene) to suffer. But the core phenomenon is similar: by developing positive relationships with the armed forces, landowners could be spared the latter's demands.

"Gifts and lavish entertainment" may well have greased these relationships, but we need not imagine they were the sole components. Perhaps the government and landowning elites were tightly interwoven by various forms of social and kin connections. Indeed, the impression given in some accounts is that the "state" should be seen as merely the official threads within a web of elite power, in which some individuals were vested with official titles and some not. Aside from kinship connections, there was the Paoge 袍哥: the not-so-secret society which “men of letters and the gentry alike compete to join [...] Almost all the officials and magistrates, men and officers are members" ${ }^{51}$ Perhaps state policy was produced by this Paoge infused network of elites and officialdom, with the result that even though all officials paid lip-service to the theory that strong state institutions should be built for the benefit of the nation, they were more interested in building strong private enterprises for the benefit of themselves and their network associates.

\footnotetext{
${ }^{50}$ Robert A. Kapp, Szechwan and the Chinese Republic: Provincial Militarism and Central Power, 1911-1938 (New Haven and London: Yale University Press, 1973), 60.

${ }^{51}$ Chen Zhongsheng, Xi xing yan yi ji, 125. The Paoge Society 袍哥會, sometimes translated as the Society of Gowned Brothers, also known as the Gelao Society 哥老會, often translated as the Society of Elders and Brothers or the Society of Elder Brothers, and occasionally the Goulu 啯嚕, (a name with no semantic meaning in standard Chinese), originated as a Qing secret society. I prefer not to translate the name because given the variety of names by which it is called in Chinese, and the lack of contemporary accounts of its name, it is unclear to me that the name was supposed to have a literal meaning - and if it was, what exactly the literal meaning was is unclear. By the Republican period the phenomena (it is doubtful that it could be called a single group or organization), had become so widespread and popular that it could hardly be called a 'secret' society anymore. It combined religious, criminal, revolutionary and mutual-aid activities.
} 
This view fits well with the dominant interpretation presented in English language writing on the late Republican Xikang government: that it was largely a vehicle for furthering the interests of Liu Wenhui and Family Inc. Barnett wrote:

When [Liu Wenhui] moved to Xikang, he was accompanied by his personal army, a horde of relatives, and the usual host of hangers-on who congregate as satellites and sycophants around a powerful local leader in China. These people took over control of the region and today they rule in General Liu's name. ${ }^{52}$

Goullart made a similar comment: "The directorate of the ["Xiling”] company, I was told contained all the top men in Sikang [Xikang], including the governor; a perfect 'family' affair as they were all more or less related." 53 And when state officials wanted land for their own private enterprises, they never seem to have had any difficulty acquiring it. Deng Pancun and Chen Dongfu acquired several hundred $m u$ in the early 1930s for their Golden Abundance Cultivation and Livestock Company (Jinbo kenmu gongsi 金博墾牧公司). ${ }^{54}$ Government officials were also privately involved with the Kham-Ning Migration and Settlement Company (KangNing kenzhi gongsi 康甯墾殖公司). ${ }^{55}$

There is certainly strong evidence that Agriculture Institute farm managers consulted local elites about expansion strategies, and that they considered the views and actions of “local gentry” (difang shishen 地方士 紳) worthy of reporting to the head office. The manager of the Hanyuan farm wrote “this summer I raised the matter of our farm's urgent need for a mulberry plantation with the local gentry, and they all approved of the idea

\footnotetext{
${ }^{52}$ Barnett, China on the Eve of Communist Takeover, 218.

${ }^{53}$ Peter Goullart, Princes of the Black Bone: Life in the Tibetan Borderland (London: John Murray Publishers, 1959), 181-82.

${ }^{54}$ Jin Gaiping 金蓋坪, "Kangding zuzhi kenmu gongsi 康定組織墾牧公司," Sichuan nongye 四川農業 1, no. 11-12(合刊) (1934): 112-13. Elsewhere, the Jinbo kenmu gongsi is referred to as the Golden Abundance Migration and Settlement Company Jinbo kenzhi gongsi 金博墾殖公司.

${ }^{55}$ Ibid.
} 
of using the old militia training ground for this purpose."56 Furthermore, local gentry in Xichang appear to have been able to negotiate with the government on how much tax they had to pay. ${ }^{57}$ Unsurprisingly given such arrangements, huang land in Xichang was not only not subject to punitive tax rates, it was exempted from tax entirely.

More clues about the nature of the relationships that bound state officials and landowning elites emerge from the government's handling of the catastrophe that many landlords faced in the era of wartime and post-war hyperinflation. Wherever rents were paid in cash and contractually fixed, hyperinflation wiped out landlords' incomes. To make matters worse, in 1941 the central government stipulated that the land tax had to be paid in kind rather than in cash. This meant that having seen their rental incomes collapse, landlords were forced to buy grain at prices that spiralled ever upwards in order to pay their taxes. In Kham, most landlords were immune to these devastating changes because their rents were typically paid in grain. In Ningshu and Yashu, ruined landlords desperately sought to renegotiate tenancy contracts, often seeking to repossess their lands, including those rented to the state agricultural enterprises. The Xikang government considered three potential responses. ${ }^{58}$ Firstly, it could ignore the landowners and continue the leases according the contracts. Secondly, it could accede to the landlords' requests and return the land. Thirdly, the state could buy the land, which was presumably the second best option for the landlords. In 1946 the provincial government created a convoluted system for determining which course of action to take. ${ }^{59}$ All scenarios, except for the apparently impossible situation in which the land value had declined despite hyperinflation, led to it being either returned or bought. With the

\footnotetext{
${ }^{56}$ Xikang sheng nongye gaijin suo. Hanyuan nong chang changzhang 漢源農場場長, correspondence with Director of Agriculture Institute, 1947, (SCDAG, QZH: 249, AJH: 101).

${ }^{57}$ Xikang sheng canyi hui 西康省參議會, "Linshi canyihui, di san ci hui huibian 臨時參議 會第三次會匯編," 1942, (SCDAG, QZH: 204, AJH: 16), 72b.

${ }^{58}$ Xikang sheng nongye gaijin suo. Hanyuan nong chang changzhang Yan Zhilong 漢源農 場場長嚴治隆, correspondence with Director of Agriculture Institute, 1947, (SCDAG, QZH: 249, AJH: 101).

${ }^{59}$ Ibid.
} 
widespread termination of the leases, Xichang’s Madaozi farm, for example, cancelled all its leases, the government again acted favourably towards landowners even though it had no obligation to do so. ${ }^{60}$

Despite the government agreeing to their requests, however, landlords who successfully got out of their tenancy agreements did pay a cost. The deposits (yazu 押租) that the government had paid when the leases were created were adjusted for inflation. "If the 1940 land value was 51,000 yuan and the deposit for the tenancy was 5,400 yuan, and the 1946 land value is $51,000,000$ yuan, then the deposit returned should be 400,000 yuan.” 61 Elsewhere in China courts ruled that deposits did not have to be adjusted for inflation. ${ }^{62}$ Even without such payments, the extent to which the land was really "given back" was questionable. "It is hoped that after the land has been given back, [landlords] will continue to grow cotton and will accept the guidance of the Ningshu office of the Agriculture Institute.”,63

Thus there is a certain amount of ambivalence to the government's handling of the issue. It was kind to landowners but not very kind. It let them out of contracts when they faced ruin, but forced them to pay back inflation adjusted deposits that could have tipped some of them over the edge anyway. And in case the landowners survived, they carried the "hopes" of the government that they would continue to implement its development plan under the direction of state agencies. Perhaps hyperinflation shifted the balance in the state-elite network, causing the influence of elites to wane. It humbled formerly prestigious and influential landowners and empowered a provincial government with more ready access to the money printingpresses.

\footnotetext{
${ }^{60}$ Xikang sheng nongye gaijin suo. Ningqu nonglin chang changzhang Xie Kaiming 寧區 農林場長長謝開明, correspondence with Director of Agriculture Institute, 1945, (SCDAG, QZH: 249, AJH: 79).

${ }^{61}$ Xikang sheng nongye gaijin suo. Hanyuan nong chang changzhang Yan Zhilong 漢源農 場場長嚴治隆, correspondence with Director of Agriculture Institute, 1947, (SCDAG, QZH: 249, AJH: 101).

${ }^{62}$ Huang, Code, Custom and Legal Practice in China, 91.

${ }^{63}$ Xikang nongye gaijin suo. Ningshu banshi chu 寧屬辦事處, "Tuihuan Madaozi mianchang bufen zudi banfa 退還馬道子棉場部分租地辦法”, 1944, (SCDAG, QZH: 249, AJH: 79)
} 
However, even in the time before hyperinflation, there are limits to the thesis that the decision not to appropriate huang land was due to the relative importance of landowners and unimportance of state institutions to regional government officials. For one thing, renting land rather than buying or expropriating it was the uniform policy of all the enterprises under the Agriculture Institute, a policy that was clearly made at the highest levels of the government. Tenancy agreements, as well as the documents relating to the giving back of land during hyperinflation show that the government's treatment of its landlords did not vary much. By contrast, Richard Gunde argues that "By freely wielding their power as a political elite, [...] the [Sichuanese] warlord and bureaucrat landlords constructed a system of taxation that oppressed some landlords, but left others, namely themselves untouched." ${ }^{4}$ Why not adopt the same selective oppression of poorly connected landowners in Xikang?

Furthermore, more than one group of people could take advantage of the possibility of bribing government officials or using Paoge and other kinds of connections to get what they wanted. The settler forced to pay rent for a grave site was presumed to be a poor, hapless individuals who was easily bullied around by the wealthy landlords. But not all people who stood to gain from Zhao Erfeng-ist free use of huang land fit this description. Agribusinesses, cultivation societies and rival landlords could be powerful and influential. In a retrospective account of the Leshan-Pingshan Cultivation Society (the successor to the Bathang Cultivation Society mentioned in chapter two), one of its founders described how, in 1910, the society had bribed Qing officials at the Provincial Bureau of Commerce and Industry (quanyedao 勸業道) to register their society so it could take advantage of regulations designed to encourage the cultivation of privately owned huang land.

A landlord of Zhongzui of powerful social standing, one of the wealthiest in the township, came to “make representations” (fasheng jiaoshe 發生交 涉). We told him that Zhou Xiaohui 周孝懷 of the Bureau of Commerce

${ }^{64}$ Richard Gunde, "Land Tax and Social Change in Sichuan, 1925-1935," Modern China 2, no. 23 (1976): 33. 
and Industry was lobbying the government to register (li'an 立案) our society. If the land were declared state-owned wasteland (guan huang 官 荒), we would have ten years tax free use of it [...]. If it were declared privately owned wasteland (minhuang 民荒), the landlord would have one year to cultivate the land himself, or else the Leshan-Pingshan Cultivation Society would be allowed to cultivate it in perpetuity and need only pay [extremely low] [...] “wasteland rents” (huang zu 荒租). [...] For the next twenty years, no more landlords ever came to make representations with us again. ${ }^{65}$

In theory, to register with the Bureau the society had to be able to show that its capital stock was worth at least twenty thousand yuan. ${ }^{66}$ The society had much less than this but managed to get the Bureau to register it through a combination of deceit and bribery. Society agents "squandered an enormous amount of money” entertaining Bureau officials. Once in the mountains, they told the officials that the Society had spent the money raised through the sale of shares on grain. "Using the excuse that storehouses had not yet been built, [we] told the commissioner that this or that family's grain belonged to the society.” The commissioner believed them and the society was registered. Hence, another problem with the thesis that corruption was the sole reason that officials ignored the law and allowed landowners to own and charge rent on huang land is that corruption could also work against landowners and allow outsiders like the Society to take over huang land even when they had not fulfilled all the legal requirements for doing so.

\section{State Revenue}

A different explanation for the government's decision not to appropriate huang land relates to its relationship with land, rather than people. It is an explanation that highlights the way that the government funded itself. Delving into state finances is a perilous undertaking, particularly in the

\footnotetext{
${ }^{65}$ Yang Gengguang, "Sichuan Le-Ping kenwu gongshe," 9.

${ }^{66}$ Ibid.: 6.
} 
Republican period. Jerome Ch'en notes that one set of budget figures used in his study of the eastern Sichuan-Hubei highlands "were a pipe dream and a warning to myself and those who are interested in studying the government finances of Republican China that budgetary figures were just dreams.” ${ }^{67}$ Nevertheless, because organizations' policies are likely to be influenced by the way they raise revenue, the interpretation of these particular dreams is a worthwhile, if difficult, endeavor.

From a certain point of view, Qing magistrates were justified to connect huang land to, in the vivid words of Ruth Meserve, "the horror of devastation and desolation." 68 Chinese administrations sometimes had difficulty deciding whether or not land used for grazing livestock counted as huang or not. But in the cool light of Qing budgets, it did not really matter. Almost all revenue generated from Sichuan frontier resources came in the form of land taxes levied on cultivated land. Using the official price of 20 Tibetan yuan per shi of highland barley, the Kangding land tax was worth 20,760 Tibetan yuan in 1910; 99 percent of county government revenue, given that livestock taxes amounted to only 203 Tibetan yuan. ${ }^{69}$ Customs revenue belonged to the national government and, in any case, was mostly generated by the traffic of Sichuanese tea through frontier counties, rather than by resources from the frontier counties. Even in a county like Lithang, where there was even more herding and less crop growing, the land tax was worth 17,753 Tibetan yuan, and livestock taxes only 2,431 Tibetan yuan. Whether it was used for grazing animals or used for nothing at all, grasslands were unproductive from the administration's perspective in that they produced only a very small amount of revenue compared to cultivated land. Livestock owners did not get a free-ride: they faced the wula corvée tax, which was a much more onerous burden in many cases and will be discussed in chapter four. Wula however, did not result in cash income for governments: there was no reason for the Qing frontier administration to see

${ }^{67}$ Jerome Ch'en, The Highlanders of Central China: A History 1895-1937 (Armonk, N. Y.: M. E. Sharpe, 1992), 116.

${ }^{68}$ Ruth Meserve, "The Inhospitable Land of the Barbarian," Journal of Asian History 16, no. 1 (1982): 61.

${ }^{69}$ Zhao Erfeng and Wu Fengpei, Zhao Erfeng Chuan bian zou du, 81. 
livestock as a potential source of revenue rather than a resource that it needed but only in finite quantities.

This changed dramatically in the Republican period, when all county governments experimented with different kinds of extra taxes. ${ }^{70}$ Specific rates and levies varied from county to county, but everywhere direct and indirect taxation on animal resources as a share of total revenue increased significantly. The new butchery tax (tu shui 屠稅), which was an indirect tax on livestock, accounted for 20 percent of Kangding county government revenue in $1932 .^{71}$ The share of county income generated by the livestock tax had risen from less than one percent to four percent by the same year. Two new taxes on opium and alcohol consumption amounted to three percent together, and the deed tax, which had existed elsewhere in China during the Qing but had not been collected in Kangding, amounted to five percent. The deed tax was significant for another reason too, as we will see below. This meant that taxes on grain had dropped from 99 percent to 68 percent of on-the-books county government revenue. Although the land tax still brought in three times as much revenue as animal related taxes, the contrast with the Qing period, when the difference has been a factor of a nearly a hundred, was significant. Furthermore, as we shall see in chapter four, Republican period governments levied more animal transport corveé than Zhao Erfeng.

Butchery taxes were also hugely important in Ningshu in the Republican period. Of the levies that Yuesui remitted to the provincial government, the land tax accounted for 47 percent and the butchery tax for 20 percent. $^{72}$ There is an uncertainty here that was largely absent in Kham, where most livestock were goats, yaks or horses that grazed mostly on uncultivated pasture. Goats and horses were raised on grazing land in Ningshu too, but some of the animals butchered in Yuesui were pigs raised in sties on cultivated land.

\footnotetext{
${ }^{70}$ Chuanbian caizheng ting 川邊財政廳, "Ge xian liangshui diaocha biao 糧稅調查表," 1932, (SCDAG, QZH:197, AJH:42).

${ }^{71}$ Ibid.

${ }^{72}$ CKSB, 188-89.
} 
Despite this uncertainty, throughout the whole Sichuan frontier region, Republican period Han local and regional governments drew on livestock resources much more than their Qing predecessors had. The question of whether or not grazing land was huang was now more important for governments. Whichever way it was answered there would be further difficult questions. Agriculture Institute records often made pastoral land (fangmu di 放牧地), together with forested land, a sub-category of huang land. One survey, for example, estimated the area of huang land in each county, broken down into the percentages of forest, grazing land, chaicao di 柴草地 (“firewood land”) and “other huang land”. ${ }^{73}$ This being the case, given the changes in where their income came from, it seems very improbable that magistrates could have still considered huang land ipso facto, to be unproductive, associated only with "devastation and desolation". Even if governors continued to accept the idea that more cultivation was desirable, the dichotomy between unproductive huang land and productive cultivated land was surely no longer tenable. Yet, to a large extent it was precisely this dichotomy between huang and cultivation that justified state appropriation of huang land.

Of course, even though a dichotomy between huang (inclusive of grazing land) and cultivated land now made less sense, the government could have decided to appropriate huang land anyway as a part of an atavistic return to Zhao Erfeng-ism. However, while almost nobody in the Kham or upland Ningshu had possessed title deeds to uncultivated land issued by a Chinese government in the Qing, Republican period governments issued a very large number of titles to huang land. They did this for two reasons. Firstly, as the French missionary F. Gore reported, county magistrates sold off land appropriated by the Qing administration. ${ }^{74}$ It is probably impossible to determine exactly how much land was sold in this manner because the practice was illegal.

\footnotetext{
${ }^{73}$ Xikang sheng nongye gaiji suo, "Xikang sheng tudi hukou diaochabiao 西康省土地戶口 調查表," 1947, (QZH: 249, AJH: 152).

${ }^{74}$ Goré, F., "Kang Zang minzu za xie 康藏民族雜寫 [Notes sur les Marches Tibétaines du Sseu-tch'ouan et du Yun-nan]," Li Zhesheng 李哲生 (trns.), Kang Zang yanjiu yuekan 康 藏研究月刊, no. 28-29 合刊 (1949 [1923]): 52.
} 
Secondly, Republican era local administrations issued land title to huang land in order to collect the deed tax (qishui 契稅). This was levied on property titles and transactions authorized by the government. It was collected as a percentage of the value of the transaction, on both outright land sales and conditional sales. In Xikang the normal deed tax rates were six percent on outright sales and three percent on the conditional sales, although like most Republican period taxes, it was also subject to local surcharges. This tax had existed during the Qing dynasty, but in Kham, Zhao Erfeng did not levy it on the titles his government granted to migrant farmers. ${ }^{75}$ Migrants were not allowed to resell these titles, and all huang land was supposed to belong to the government, so in theory the deed tax could only ever be levied on transactions involving urban property and land already cultivated by indigenous people. The Qing government made no attempt to issue the indigenous people with land-titles, however. ${ }^{76}$ There may have been a very small amount of deed tax collected on urban property transactions involving Han settlers in places like Kangding, but this does not appear in any of the frontier administration budgets used by this study. ${ }^{77}$ If it existed, it must have been in the category of "miscellaneous taxes (zhengza shui 正雜稅)”, which amounted to less than one percent of tax revenue from within the Kham region. ${ }^{78}$ In Ningshu, away from established centres of Han population, tusi issued Han migrants hong zhao 红照 land-rights contracts - these will be discussed in chapter five: here we need only note that Chinese authorities appear to have had nothing to do with them.

\footnotetext{
${ }^{75} Q C B D, 1: 122,2: 458$.

$76 \mathrm{JKDZ}, 113$.

${ }^{77}$ Yang Jianwu 杨健吾, "Minguo shiqi kangqu de jinrong caizheng 民国时期康区的金融 财政," Xizang yanjiu 西藏研究, no. 3 (2006).; Huang Fensheng, ed. Meng Zang xin zhi, 895; Ma Jinglin, Qing mo Chuanbian Zang qu gaitu-guiliu kao; Weng Zhizang 翁之藏, Xikang shi kuang 西康實沉 (Shanghai: Min zhi shu ju, 1930), 168.

${ }^{78}$ Weng Zhizang, Xikang shi kuang, 168. Sources give different figures for local tax income. Some give the land tax income in grain, while others give it as a cash amount. Some use a vague “goods tax huowu shui 貨物稅” category, and it is uncertain what this includes. But any reasonable reconstruction of the total tax income would make the "zhengza shui" less than one percent of the total.
} 
In 1914 the Sichuan Frontier Department of Finance (caizheng bu 财政 部) established a Deed Tax Collection Office ( $q$ i shui chou ban chu 契稅籌 辦處). It noted that in Kham “there are no official deeds, and there are frequent disputes caused by allegations of trespassing. Now, deeds will be granted to landowners without exception, in order to prevent conflicts and increase tax revenue (yu shui ru 裕税入)." ${ }^{\text {79 }}$ The same lines or variations of them appeared multiple times in government communications on the subject. ${ }^{80}$ Because only a very small number of landowners in Kangding and Luding already possessed land deeds, estimations of the potential income that could be gained by issuing them with a small tax on each were very large indeed. The magistrate of Gong County, between Ba'an and Chamdo, figured that about 35,000 Tibetan yuan would be collected from his small and thinly populated county. ${ }^{81}$ This must have been a huge overestimate, but actual income could be substantial. In 1916, the Gyaisi county authorities succeed in raising 4,170 dayang yuan by issuing deeds for property categorized as “fields”, “pasture (muchang 牧場)”, “buildings” or “temple estate". ${ }^{82}$ In the past, officials had had an incentive to register land as huang so that migrants could be settled on it; now there was an incentive to register it in one of the other categories and permit private ownership of it so that more tax could be collected. 4,170 dayang 大洋 yuan may have been something of a disappointment, but it would have covered most of the costs of, for example, grain rations for a garrison of about 150 soldiers for a

\footnotetext{
${ }^{79} \mathrm{JKDZ}, 113$.

${ }^{80}$ See for example, Chuanbian zhenshoushi shu 川邊鎮守使署, "Qi shui choubanchu cheng 契稅籌辦處呈," 1914, (SCDAG, QZH:195, AJH:4).

${ }^{81} \mathrm{JKDZ}, 117$.

${ }^{82}$ Ibid., 120.
} 
year. ${ }^{83}$ Gyaisi County's population was estimated at around 12,000 in the 1930s, so a garrison of 150 would have been a meaningful presence. ${ }^{84}$

The initial deed tax bonanza ended after those landowners who could be coerced or otherwise persuaded into paying for an official title deed did so. Thereafter the tax was collected when the government issued new deeds to purchasers of real estate. In places where there was a significant amount of buying and selling of land revenue could still be significant. The Kangding records quoted above indicated that the deed tax amounted to seven percent of the value of the land tax in 1932. Throughout the 1930s the relative value of the tax grew significantly. In Kangding in 1939, revenue from this tax was worth 7,600 yuan. ${ }^{85}$ In that year the land tax was, in theory, worth about 47,150 yuan, if the amount given in grain $\left(1,886\right.$ shi) ${ }^{86}$ is converted into cash at market prices (roughly 25 yuan per shi in 1939$)^{87}$, so in theory the deed tax was now worth 16 percent of the land tax. In reality, its relative worth was higher than this because the government often allowed the land tax to paid as a cash payment at what was a below market price for the amount of grain owed. ${ }^{88}$ In 1940, provincial government records calculated that in the province as a whole, deed tax income was equivalent to a massive 33 percent of the land tax income. ${ }^{89}$ According to the same records by that time, it had become the third most important tax to the provincial

\footnotetext{
${ }^{83}$ A soldier would have needed around three eastern China shi of grain per year. One guan shi (double the size of a normal shi-see chapter six) cost about 42 Tibetan yuan at Kham market prices in $1915(\mathrm{JKDZ}, 85)$. Three eastern China shi $=1.5$ guan shi $=63$ Tibetan yuan $=28.35$ dayang yuan. So 4,170 dayang yuan could buy basic grain rations for 147 soldiers for a year.

${ }^{84}$ Qiu Shuling 邱述鈴, "Jiulong jingji jianshe zhi yantao 九龍經濟建設之研討," Kangdao yuekan 2, no. 1 (1939): 42.

${ }^{85}$ Xikang sheng caizheng ting, Jian sheng hou zhi Xikang caizheng.chapter six, p.7.

${ }^{86} \mathrm{JKDZ}, 82-83$.

${ }^{87}$ See chapter six

${ }^{88}$ CKSB, 396; JKDZ, 85-86, 120.

${ }^{89}$ Xikang sheng caizheng ting, Jian sheng hou zhi Xikang caizheng. Chapter 5, p. 16. The land tax income of that year is given as 577,411 yuan, and the deed tax 189,432 yuan.
} 
government and the most important tax to local governments (it is unclear how the income from it was divided between the two.) ${ }^{90}$

In some Ningshu counties, the deed tax was even more significant for county governments. Astonishingly, according to some records, Mianning's deed tax revenue was higher than its land tax revenue in $1941 .{ }^{91}$ Records of Ningshu tax revenues are more varied than records from Kham, perhaps because the Ningshu's administration was more complex due to a higher population and more diverse economy. But while Mianning's deed tax may not actually have been higher than its land tax, all the records that I have seen indicate that it was a highly significant source of revenue. ${ }^{92}$

It was a tax that should have retained its importance through the era of hyperinflation because it was collected as a percentage of transactions' value, rather than as fixed amount (like the livestock tax), and because it was collected throughout the year. According to one writer, there was a robust trade in land throughout the 1940s because small capitalists had "little faith in the national currency" and "came to see purchasing land as the most reliable [store for wealth], and everybody began buying land. From the hinterlands to the core, from southeast to northwest, there was a great competition among the wealthy to buy land."93

Just as in early Republican Kham, county officials mindful of the importance of this source of revenue had an incentive to grant individuals title to uncultivated land. For each transaction in the 1940 Kangding deed tax records there was a single word description of the type of land involved, and some stated that the land was, indeed, huang or forest. ${ }^{94}$ Most of the records simply described the land as “mountain land” (shan di 山地), without noting what, if anything, it was used for. Buyers (or the tax office)

\footnotetext{
${ }^{90}$ Ibid. Chapter 6, p. 6.

${ }^{91}$ Ibid. Deed tax: chapter 6, p.7. Land tax: chapter 6, p.12.

${ }^{92}$ CKSB, 188-92.

${ }^{93}$ Zhou Maoqi 周茂歧, "Cong tudi wenti shuo dao "hong zhao" zhengli 從土地問題說到 『紅照』整理," Bianzheng yuekan 邊政月刊 1, no. 4-6(合刊) (1944): 53.

${ }^{94}$ Tang Denghan 唐登漢, "Xikang sheng Kangding xian zhengfu chengbao dian mai qishui zhengshou 西康省康定縣政府呈報典買契稅徵收," 1940, Xikang sheng caizhengting 西康省財政廳, (SCDAG, QZH:207, AJH:144).
} 
may well have recorded uncultivated or forested land as "mountain land" as a precaution against problems that could have arisen had the provincial government decided to make good its proclamation of one year earlier that huang land was public property. Most of the names in the records are Han Chinese names, though this does not mean that some were not Tibetans or people of mixed ancestry using Chinese names. But in seven of the 128 transactions, someone with an obviously Tibetan name bought land from a person with a Han name, and in two transactions both the names are clearly Tibetan.

In sum, subjectively, the huang land that officials encountered in the late Republican period was different from the huang land that the Qing administration had dealt with. It produced almost no income for the Qing government, but a substantial amount of revenue for Republican governments. Moreover, in the Qing it had not been covered with any form of legal title that Chinese governments recognized. By the late Republican period, large numbers of people, particularly those nearby Chinese administrative centres and including indigenous people, possessed titles to huang land that had been created by local Chinese authorities. This was one of the key reasons for the difference between the Qing and Republican period administrations' behaviour regarding uncultivated land in the highlands.

\section{Conclusion}

In the second half of the Republican period a strong Chinese state reemerged in the eastern part of the highlands. Of course, in many places in Kham and Liangshan, this state was, as Hsiao-ting Lin puts it "merely a foreign body to the Xikang natives, with limited influence over the infrastructure."95 But the triangle between Ya'an, Kangding and Xichang, as well as certain other places such as Taining, was, in James Leibold's words,

${ }^{95}$ Lin, Tibet and Nationalist China's Frontier, 68. 
Liu Wenhui's “fiefdom”. ${ }^{96}$ There were some significant continuities between Liu Wenhui's regime and Zhao Erfeng's. Both were Kham-centric. Both maintained the theory that huang land belonged to the state. Republican period settlement societies and companies implemented regimes to foster and control migrant communities that were obviously inspired by Zhao Erfeng's system. However, differences were substantial. Despite what it said, Liu's government gave up on the idea that huang land was public land and, with one significant exception to be explored in the next chapter, even state-owned agricultural enterprises rented their land from private owners, even when it was registered as huang.

This may strike us as paradoxical, because it seems to clash with another significant change that occurred in the Republican period: the rising importance of state-owned enterprise. In contrast to Zhao Erfeng, who aimed to develop communities of peasants with small amounts of land that they leased from the state, Liu Wenhui's government concentrated its agricultural spending on a cluster of provincial government owned enterprises, which employed migrants as waged labourers. Some of the reasons for the change in agricultural strategy and for the significance of the state owned enterprises in Kham will be explored in the following chapter.

How is it that state institutions became more important for the government's development strategy, but the government became less inclined to use state power to appropriate huang land? Was the Han state in the highlands growing or withering? The decision not to take over huang land can be partially attributed to the way that Liu's regime was solidly embedded in a network of landowners and regional elites. However, this does not explain why the provincial government did not just pick on poor or poorly connected landlowners. In fact, we need not see the government's decision to rent huang land as a result of the weakness of state institutions. It can be explained by changes in the sources of provincial and local government revenue. Government at both levels drew a much greater proportion of their income from huang land, in the form of taxation of animal products or taxation of land trading, than the Qing state had done.

\footnotetext{
${ }^{96}$ Leibold, Reconfiguring Chinese Nationalism, 69.
} 
Taxation of land titles also encouraged a vast expansion in the amount of land covered by titles that Han authorities recognized. Comparing the Republican and Qing governments' ability to extract wealth from the frontier, the Republicans added these forms of tax revenue at the cost of the Agriculture Institute enterprises having to pay small amounts of rent to private landowners. It was probably a worthwhile move that left them, on balance, better off than their Qing predecessors had been. 


\section{Chapter Four: Corvée Labour and the Development of Local and Regional Chinese Authority in Kham}

"Certainly if anyone deserves to go to Lhasa and get a medal for it, it is the supply and transport man. But he will be left behind."

-Edmund Candler (1874-1926).

Thus far we have looked at the development of Han Chinese regional and local authority in the highlands west and southwest of the Sichuan basin between 1905 and 1949. In chapter one I argued that, if one takes into consideration the immense difficulties that regional Han governors faced and judges them by more realistic standards than those they set for themselves, this state-building endeavour was rather more successful than many historians have assumed. This modest success was thanks in no small part to subsidies from the national and Sichuan governments, and, from the mid-1930s, to a war on drugs that gifted the highland state a lucrative source of revenue. However, it was also achieved through adaptation to local circumstances. The Han-dominated highland authorities that emerged in the first half of the twentieth century were not merely copies of a generic Chinese form, but were fundamentally influenced by the ways they attempted to resolve the core problems of governing this region. This chapter demonstrates this with respect to Kham and the next chapter does the same with respect to Ningshu.

In a 1940 article, Liu Wenhui argued that there were three key matters requiring government attention in Xikang. ${ }^{2}$ These were: the "Yi problem" in Ningshu; religion and the government's approach to religion in Kham; and the problems relating to the wula 烏拉 corvée labour tax in Kham. The "Yi problem” is the subject of chapter five. Of the two Kham-related problems that Liu mentioned, this thesis concentrates on wula for two reasons. Firstly,

\footnotetext{
${ }^{1}$ Edmund Candler, The Unveiling of Lhasa (London: Thomas Nelson and Sons, 1905), 56. Candler was a journalist, novelist, educator, and Daily Mail correspondent 'embedded' with Younghusband's Tibet expedition.

${ }^{2}$ Liu Wenhui, "Ganzi shibian jiejue jingguo 甘孜事變解決經過," Kangdao yuekan 2, no. 8 (1940): 8.
} 
I feel that it was a more serious difficulty for the government and certainly it generated a very large volume of discussion that referred to it as a “problem”. By contrast, discussion of religion was less likely to explicitly consider it a "problem" that needed to be resolved. Liu's focus on religion might have been partly due to his own personal interest in Buddhism. According to Sun Shuyun, Liu himself was a devout Buddhist. ${ }^{3}$ Peter Guillart notes that "the superstitious and backward Governor would not take a step without recourse” to "Soong Lama” in Kangding, who was his "unofficial soothsayer." 4 Liu’s government established Wuming (wu ming 五明, Five Sciences) Buddhist Colleges from 1938 in several places in Xikang (discussed briefly in chapter seven). ${ }^{5}$ The other reason for focusing on corvée labour rather than religion is that the relationship of Republican era Chinese politics and Tibetan religion is much better served in the existing Chinese and English language literatures than the topic of corvée labour in the highlands. ${ }^{6}$

"Wula" was the Chinese transcription of the name of a customary InnerAsian tax according to which owners of carrying animals were obliged to provide transport services to government officials and armies, typically either for free or for compensation at well below market transport rates. This chapter examines the problems caused by this system in the early twentieth century, and government attempts to resolve these problems. I argue that the wula problem was of fundamental importance in defining regional and local government developmental agendas for Kham, as well as government relations with indigenous leadership and communities. There was a plurality of opinion as to what the root problem really was, and what the best way to

\footnotetext{
${ }^{3}$ Sun, The Long March, 146.

${ }^{4}$ Goullart, 29-30.

${ }^{5}$ Wang Chuan, "Minguo zhong-hou qi de zhengzhi yu zongjiao: Liu Wenhui yu Xikang diqu zangquan fojiao jie 民国中后期的政治与宗教: 刘文辉与西康地区藏传佛教界," in Yijiusanling niandai de Zhongguo 一九三 0 年代的中国, ed. Zhongguo shehui kexue yuan jindaishi yanjiusuo minguo yanjiushi 中国社会科学院近代史研究所民国研究室 and Sichuan shifan daxue lishi wenhua xueyuan 四川师范大学历史文化学院 (Beijing: Shehui kexue wenxian chubanshe, 2006), 809.

${ }^{6}$ The best work in English is Gray Tuttle, Tibetan Buddhists in the Making of Modern China (New York: Columbia University Press, 2004). In Chinese, see Wang Chuan, "Minguo zhong-hou qi de zhengzhi yu zongjiao."
} 
deal with it was. Nevertheless, discussion of the wula problem led to the formation of constellations of opinions and plans for action that had farreaching implications for the development of the Chinese state in Kham. Officials who did not like working with indigenous leadership, or those who blamed indigenous leaders for the problems with the wula system, argued for the formation of a large state-enterprise to deal with the problem. Those who were warier of state-enterprise found the only other solution was to work more closely with indigenous leaders, and deepen relations between the state and indigenous communities. Both sorts of solutions exerted an important influence on the development of regional and local Chinese authority in Kham, an influence that can be detected even in the present day.

This chapter begins with an analysis of the problems caused by this tax, and Zhao Erfeng's attempts to deal with them. Wula became a much more significant problem in the Republican period, although not necessarily for the reasons that were given at the time, which rested on a somewhat rosy construction of Zhao's regime. I then outline Republican period responses to the wula problem and demonstrate that this problem was crucial to the evolution of the Chinese authority in eastern Kham in that era.

\section{The "Wula Problem" in the Qing}

Wula, which has been romanized as "u-lag” from Tibetan, "ulaq" from Turkic and "ulagh” and “ulag-a” from Mongolian, had an extremely broad geographic and historical existence. ${ }^{7}$ The term, originally Turkic according to John Boyal, dates from the Mongol empire and continued to be used by the Islamic and Mongol states that succeeded that empire. ${ }^{8}$ It is not clear

\footnotetext{
${ }^{7}$ See James A. Millward, Beyond the Pass, 119; John Masson Jr. Smith, "Mongol and Nomadic Taxation," Harvard Journal of Asiatic Studies 30 (1970): 75; Melvyn C. Goldstein, T.N. Shelling, and J.T. Surkhang, eds., The New Tibetan-English Dictionary of Modern Tibetan (Berkeley: University of California Press, 2001).

${ }^{8}$ See Sunil Kumar, "The Ignored Elites: Turks, Mongols and a Persian Secretarial Class in the Early Delhi Sultanate," Modern Asian Studies 43, no. 1 (2007); Ata-Malik Juvaini, John Andrew Boyle, and David Morgan, Genghis Khan: the History of the World Conqueror, trans. John Andrew Boyle (Manchester: Manchester University Press, 1997), 30. Juvaini himself explained that the tax was originally one of the qubchur taxes levied only on Mongols, not the peasantry, (Kumar, "The Ignored Elites," 65.)
} 
when the tax and its lexicon entered the Tibetan world. This could have occurred during the thirteenth century Mongol Empire, as one recent Chinese historian has suggested, or on any number of later occasions. ${ }^{9}$ Goldstein reports that interviewees from a village near Gyantse in Central Tibet said that corvée service had the generic name of rkang-'gro. ${ }^{10}$ For them, 'u-lag referred specifically to human labour corvée, while riding animal corvée was rta'u ('ta-wu') and carrying animal corvée was khal-ma ('kay-ma’). In Qing administrative language, “wula” usually referred specifically to the transport corvée, which they levied in Mongolia, Southern Xinjiang and the Tibetan plateau. ${ }^{11}$

The u-lag/wula (in this thesis, I use wula) transportation corvée was appropriate for the normal requirements of a customary Tibetan administrative system that, as Goldstein notes, "delegated substantial government rights to the lords.” ${ }^{212}$ The central Tibetan government kept only a minimal military force, and did not maintain any kind of police force in rural areas. Even in these circumstances, Goldstein argues that the transportation corvée was still one of the "most difficult labour obligations for serfs.” ${ }^{13}$ Thus, even the kind of institutions and military that the Qing maintained in eighteenth and nineteenth century interior China would have resulted in great pressure on $u$-lag and the serfs who performed it.

Zhao Erfeng himself was well aware of the problems that his campaigning had caused:

Officials, petty officers, soldiers and men at arms of the Tibetan-frontier army come and go constantly. The transport of the rations and munitions that are required by the military forms an unending train, and the

\footnotetext{
${ }^{9} \mathrm{Hu}$ Xiaomei 胡晓梅, "Liu Wenhui Kangqu wula zhidu gaige shulun 刘文辉康区乌拉制 度改革述论," Sichuan jiaoyu хиеуиаn хиеbao 四川教育学院学报 18, no. 9 (2002): 36.

${ }^{10}$ Goldstein, "Taxation and the Structure of a Tibetan Village," Central Asiatic Journal 15, no. 1 (1971): 10 . ${ }^{11}$ Millward, Beyond the Pass, 119. Millward mentions the use of the corveé, but does not
provide any details as to Qing innovations.

${ }^{12}$ Goldstein, A History of Modern Tibet, 5.

${ }^{13}$ Ibid., 4.
} 
common people who live by the main routes are exhausted by rushing about performing this task. Many of them have fled. ${ }^{14}$

His comment illustrates well the practical dangers posed by allowing peasants' wula duties to rise unchecked. If overburdened peasants revolted or ran away, the transportation of goods and military equipment became impossible. It also fundamentally undermined government efforts to increase the population and revenue base of the region. ${ }^{15}$ As an official in Bathang pointed out in 1909: "In recent times, the corvée has been particularly burdensome, and they [wula providers] have no spare time to take up the cultivation of land". ${ }^{16}$ Corveé burdens were probably also a factor in the resistance to Zhao Erfeng: the Lithang tusi refused to provide transport services to Zhao for his campaign against the rebels at Bathang, precipitating a violent reaction from Zhao. ${ }^{17}$ The impression given in some accounts is that the tusi was motivated by sympathy for the Bathangese, yet there is no reason to discount the severity of the wula burden as a factor in the tusi's resistance.

Even without such practical problems, increasing the burden on peasantry also ran directly counter to Qing traditions of light taxation. ${ }^{18}$ Reductions of tax rates in newly conquered territory to lower levels than those set by the conquered government were an established way of demonstrating the munificence of Qing imperial power. ${ }^{19} \mathrm{Fu}$ Songmu gave the following account of Zhao's interaction with the people of Derge:

\footnotetext{
${ }^{14}$ Quoted in Huang Shangcheng 黃上成, "Xikang wula chaiyao zhidu zhi shi de xushu 西 康烏拉差徭制度之史的敘述," Kangdao yuekan 2, no. 5 (1940): 25.

${ }^{15}$ Particularly badly affected were places between Kangding and Kanze; a 1938 research team wrote that: "In Zhonggu and Drango and other places, in former times because of military campaigning, the corvée labour burden was too heavy for people to bear. There also they abandoned their lands and fled. [...] Thus abandoned fields can be seen everywhere beyond the pass.” Liu Hengru et al., "Shicha Dao Lu De Bai Zhan Ya Jiang qi xian baogaoshu," 39.

${ }^{16} \mathrm{QCBD}, 2: 405$.

${ }^{17}$ Sperling, "The Chinese Venture in K'am, " 18-19.

${ }^{18}$ Ye-chien Wang, Land Taxation in Imperial China, 1750-1911 (Cambridge, Mass.: Harvard University Press, 1973), 28-31.

${ }^{19}$ Millward, Beyond the Pass, 54.
} 
In first year of Xuantong [1909], the tusi of Derge was deposed and replaced with a Han civilian official. The Frontier Commissioner, Zhao gathered the Fan people at Sershul and said unto them: "Now the Derge tusi has been deposed and you will be governed by Han. Your grain taxes have already been reduced and your labour duties have been cut, we deeply hope for your development. ${ }^{20}$

Zhao probably never said this to the people of Derge at all. Indeed, in official communications Zhao openly acknowledged that labour duties had not been cut in Derge, but, on the contrary, the presence of his forces had “added a great burden to the people’s lives.”21 However, Fu's description probably indicated how Zhao would have liked to have acted, and more importantly, been seen to have acted. It demonstrates the extent to which the officials in his administration, like their forebears in Xinjiang, regarded cutting taxes in a newly absorbed territory as an effective demonstration of benevolent rule, another reason that adding to the burden of the peasantry was deeply problematic.

Wula was different from other forms of heavy taxation in that it was a localized corvée that was essential to the basic operation of the state military and bureaucracy. New taxes collected in money or produce could theoretically be shared across a whole region equitably and levied at rates proportional to local wealth. Wula burdens inevitably fell unequally on communities where the government needed transport. Pack animals, handlers and fodder were not brought in from outside regions to spread the load evenly according to the natural distribution of resources. As we shall see, this solution was attempted in the Republican era, but it was very difficult to organize, and throughout the period of this study the government was basically reliant on conscripting local pack animals on an ad hoc basis.

Zhao Erfeng's military campaigns were not the first Qing forays into the Tibetan highlands and the problem had occurred before. From the Kangxi reign (1662-1722) to the end of the dynasty, the government response to these problems was to make payments to wula providers and to stipulate

\footnotetext{
${ }^{20}$ Fu Songmu, Xikang jiansheng ji, 3:30.

${ }^{21}$ QCBD, 2:303.
} 
limits on how much officers and officials could demand of them. The early and mid Qing period had produced a lot of documentation relating to wula. The first Qing references to it in the Tibetan areas occur in the Kangxi period, and they usually indicate that livestock owners were paid for the service. $^{22}$ The court promulgated regulations to govern compensation and officials' use of the corveé as early as the fourth year of the Qianlong reign (1739). ${ }^{23}$ Yingcong Dai confirms that during Qianlong's campaigns in Jinchuan (1747-49 and 1771-76) "not only did the Qing pay for the non-Han labourers and 'ula,' but also granted awards and extra pay in the event of an emergency, transportation tasks becoming urgent.”24

Zhao Erfeng maintained Qing tradition and ordered that payments be made for wula service. In addition, he created a large number of wula related regulations. These were promulgated in an ad-hoc fashion in a number of different documents and were often specific to a certain locality. For example, in Ba'an (Bathang) payments were increased to take into account the high demand and the large area from which peasants were recruited, which often entailed longer journeys. ${ }^{25}$ In July 1911, a set of regulations intended to replace all previous provisions throughout the whole of Kham was produced. ${ }^{26}$ This last wula code contained twenty six articles and made the corveé by far the most comprehensively regulated aspect of the new administration's interaction with Kham society. The wula articles laid out the rights and duties of peasants in great detail, leaving few aspects of the corvée untouched. Payments were to be half a Tibetan yuan per animal per day, or four wen (文) per $l i$; or for a human porter a quarter of a yuan per day. A yak could be loaded with a maximum of 120 jin 斤, a

\footnotetext{
${ }^{22}$ Chen Yishi, "Chuan bian Zangqu jiaotong wula chaiyao kaosuo," 48-52.

23 Ibid.: 59 .

${ }^{24}$ Dai, "The Qing State, Merchants, and the Military Labor Force in the Jinchuan Campaigns," 59. However, as Dai notes, the Qing also banned the non-Han rGyal-rong people from going to the Chinese areas to work as agricultural labourers, possibly with the intention of increasing the amount of labour available for ula, and thereby limiting the pressure on the government to increase compensation.

${ }^{25} \mathrm{QCBD}, 1: 104$.

${ }^{26}$ Zhao Erfeng and Wu Fengpei, Zhao Erfeng Chuan bian zou du, 198-203.
} 
human porter with 60 jin, horses were to carry only one rider, no matter the size of the rider. Compensation for animals that died in service was to be paid at market rates, to a maximum of twenty taels per horse or ten taels per yak. Another article gave compensation amounts to be paid in the event of damage to saddles, reigns and other items. Wula was to be levied on households according to their ownership of animals or grain tax duties.

If Zhao's approach to wula seems more thorough than that of his eighteenth century predecessors, this was most likely due to changes in military technology rather than ideological orientation. Zhao noted that each large cannon (dapao 大炮) had to be carried by several men, with several more being required for the emplacement (paowei 炮位) and still more for the shells. ${ }^{27}$ During the Jinchuan wars, the Qing had also used heavy artillery, but had adopted the tactic of manufacturing cannon on site in order to reduce the transportation burden. ${ }^{28}$ The Jinchuan campaigns had been focused on a relatively small geographic area (400 li according to Qianlong), while Zhao's sphere of activity stretched the entire breadth of Kham, so it would have been more difficult for him to implement such a labour saving tactic. ${ }^{29}$ This likely resulted in greater demand for transport services and a somewhat more significant wula problem than that faced by earlier military leaders in the Tibetan lands.

Republican period knowledge of wula in the Qing

Republican period writers and officials believed that Zhao Erfeng's regulations had essentially solved the problem. Jiang Junzhang’s 蔣君章 comment in Bianzheng gonglun 邊政公論 is typical:

\footnotetext{
${ }^{27} Q C B D, 2: 334$.

${ }^{28}$ Joanna Waley-Cohen, "China and Western Technology in the Eighteenth Century," 1537-38.

${ }^{29}$ Peng Zhiyan 彭陟炎, "Shi lun Qianlong pingding Jinchuan zhi yingxiang 试论乾隆评定 金川之影响," Xizang yanjiu 西藏研究, no. 1 (2003): 4.
} 
We know that Zhao Erfeng was a vigorous and severe administrator, whose orders were always strictly enforced, with no disobedience tolerated. Thus, after he had established a reasonably appropriate way of dealing with wula, the problem was temporarily resolved. ${ }^{30}$

Curiously, the history of Qing regulation of wula before Zhao Erfeng and in areas outside Kham appears to have been almost completely unknown to most Republican period officials and writers. Several writers did mention the Qing “pacification” of Tibet in the Kangxi reign as a critical moment, and understood that there was a connection between the wula institution of their own time and generals such as Yue Zhongqi 岳鐘琪 (1686-1754) and Fala 法喇 (?-1735, a Commander-in-Chief active in Kham during the Kangxi period campaigns on the plateau). ${ }^{31}$ But there was a complete and striking absence of detail in comparison to what they knew about Zhao Erfeng. Liu Wenhui noted simply that "the wula system was created in the early Qing period.”32

One small and difficult to interpret exception to this is that several Republican era authors noted that a 'human service' (ren yao 人徭) component of wula, which entailed the provision of sexual partners to traveling officials, had been banned in the Qing. ${ }^{33}$ None of Zhao Erfeng's regulations mentioned the ren yao, so if it ever existed it must have been prohibited before his arrival, which would mean that Republican writers did have some fragmentary knowledge of a pre-Zhao period reform of wula. On the other hand, this kind of service is not mentioned by Yang Zhonghua, who gave the most detailed account of the different types of corvée. ${ }^{34}$ Notwithstanding this one exception-which was never elaborated on-

\footnotetext{
30 Jiang Junzhang 蔣君章, "Wula wenti zhi jiejue tujing 烏拉問題之解決途徑," Bianzheng gonglun 邊政公論 1, no. 7-8 (combined) (1941): 20.

${ }^{31}$ Huang Fensheng, ed. Meng Zang xin zhi 蒙藏新志, 968; Zhang Zihui 张子惠, "Lihua chaiyao zhi jin xi ji qi tedian 理化差徭之今昔及其特點," Kangdao yuekan 2, no. 5 (1940): 170.

${ }^{32}$ Liu Wenhui, "Ganzi shibian jiejue jingguo," 8.

33 JKDZ, 19; Jiang Junzhang, "Wula wenti zhi jiejue tujing," 17.

${ }^{34}$ Yang Zhonghua 楊仲華, Xikang ji yao 西康紀要 (Shanghai: Shang wu yin shu guan, 1937), 289.
} 
Republican accounts can create the general impression that Zhao Erfeng was the first frontier official to regulate and pay for wula.

This was not necessarily deliberate. An article in Kham Guide Monthly suggested that Republican period writers may have suffered from a lack of access to documentary records:

Reportedly, during the Qing dynasty, the Mingzheng tusi established relay stations and wayside accommodation for the Qing officials traveling to Tibet [...] Unfortunately, there is no record of whether or not there are any regulations from that time, [...] the first documents relating to wula are those from the time of Zhao Erfeng. ${ }^{35}$

Republican period writers not only knew very little about previous attempts to deal with the problem in Kham; they were also almost entirely unaware of the origins of wula and wider geographic spread of the tax. One writer provided the term in Tibetan script with the same spelling as given by Goldstein and Jäschke, and wrote that its origins were Tibetan. ${ }^{36}$ On the institution itself, comments such as the following from a 1941 Bianzheng gonglun article are typical: "Wula is a form of corvée labour that is unique to Xikang and Tibet." ${ }^{37}$ An article in a special issue of Kham Guide Monthly on the subject stated that "Its origins must be traced far back to the formation of chiefly rule (tuqiu zhengzhi 土酋政治).”38 Qing Mongolia and Xinjiang were never mentioned in any Republican period writing on the subject that I have seen. Even those who were aware of the use of wula in Qinghai confined their analysis of the "wula problem” to twentieth century Kham, rather than discuss whether and how the issue had been resolved on other Tibetan frontiers. The problem was seen essentially as a local one, indicative of a surprisingly narrow focus of twentieth century discourse on the Sichuan frontier.

\footnotetext{
${ }^{35}$ Huang Shangcheng, "wula chaiyao zhidu zhi shi," 23.

${ }^{36}$ Ibid.

${ }^{37}$ Jiang Junzhang, "Wula wenti zhi jiejue tujing," 17.

${ }^{38}$ Huang Shangcheng, "wula chaiyao zhidu zhi shi," 23. A view that was also expressed by Zhu Zengyun: Zhu Zengyun, "Chuanbian zhengxie," 158.
} 
The Worsening Situation in the Republic

Republican period writers often contrasted what they imagined the state of affairs in Zhao's time was like with what they saw as a much worse situation in their own time. This may have involved some amount of nostalgia and a proper contrast between the two periods is difficult because of a lack of independent sources of information on the late Qing government. Most Republican writers, like Jiang Junzhang highlighted Zhao's alleged strictness and incorruptibility. ${ }^{39}$ The dichotomy between an era of impartial, ruthless commitment to the law under Zhao, and appallingly corrupt Republican period governance has been well entrenched in the Chinese and foreign historical narrative from the 1920s to the present. Zhang Zhen'guo, who was appointed by Liu Wenhui's government to the position of Wula Supervisor (jianchayuan 監察員) at Taining, listed ten kinds of corruption practiced by those who used wula, and a further four practiced by those who organized it (and still felt able to grumble about the misbehavior of the peasants themselves). ${ }^{40}$ Zhang and many others complained that officials used it for private profit rather than official business, or allowed merchants to do the same. They also charged that officials did not pay peasants in full or at all, and that they frequently ignored regulations on the maximum daily distances. The latter practice often caused animals to die, in which case compensation was hardly ever provided. Many writers also blamed indigenous leaders whom they believed were appropriating most or all of the money that was paid out for the peasants. $^{41}$ This latter problem was especially significant because it was connected to the question of the broader relationship between Chinese officials and indigenous leadership. As I shall show, officials' proposals for

\footnotetext{
${ }^{39}$ Jiang Junzhang, "Wula wenti zhi jiejue tujing," 20-21.

${ }^{40}$ Zhang Zhen'guo 張鎮國, "Feichu Kang qu wula zhidu jianyi shu 廢除康區烏拉制度建 議書," Kangdao yuekan 2, no. 5 (1940): 128-30.

${ }^{41}$ See Jiang Junzhang, "Wula wenti zhi jiejue tujing," 21-22; Ren Zhuo 任灼, "Wula zhidu yu guan ying mu yun 烏拉制度與官營牧運," Kangdao yuekan 康导月刊 2, no. 5 (1940): 14.
} 
a solution to the wula problem were significantly influenced by their ideas concerning this relationship (and vice versa).

Not all accounts give such a clean picture of Zhao's forces. Chen Zhongsheng reported hearing that: "After the imposition of direct rule, the Qing officials and soldiers trampled over and exploited the people everywhere they went." ${ }^{42}$ However, even if Zhao indeed enforced his wula regulations more rigorously than Republican era governments did, ensuring the compliance of both the Chinese and native leadership, this was not the only reason that wula became a much greater problem after the fall of the Qing. As we saw in chapter one, funding to frontier authorities was unreliable in the late 1910s and 1920s. Han regional authority recovered from the late 1920s, though until the opium export boom of the late 1930s and 1940s it was probably worse off than Zhao's administration had been. For several reasons, financial difficulties exacerbated the wula problem.

Reliable and generous outside support meant that his administration could afford the wula payments more easily than Republican era authorities. This was very likely the reason that wula payment rates were not raised until 1936 (at exactly the time that the Xikang government began benefiting from opium exports). Before then, wula regulations had been extensively revised, but the stipulated payments remained at half a Tibetan yuan. ${ }^{43}$ In 1936 this was raised to one yuan per yak and one and a half yuan for a horse. ${ }^{44}$ The rate of inflation in the twenty five years before this is difficult to judge with much precision, but food prices appear to have risen by about 67 percent over this time. $^{45}$

${ }^{42}$ Chen Zhongsheng 陳重生, Xi xing yan yi ji 西行灎異記 (Shanghai: Shanghai shibao, 1930), 239.

${ }^{43}$ For a 1929 set of regulations produced by the Sichuan-Xikang Border Defence Force 川 康邊防軍, see Huang Shangcheng 黃上成, "wula chaiyao zhidu zhi shi," 34-36. Also published in JKDZ, 200-02.

${ }^{44} J K D Z, 210-12$.

${ }^{45}$ In 1915 highland barely cost 1.5 Tibetan yuan for 10 jin (JKDZ, 85-86). In 1937 it cost about 2.5 Tibetan yuan for 10 jin. (The October 1940 highland barley price, which was about 7.7 times higher than the 1937 average, was 87 dayang yuan (roughly 196 Tibetan yuan) per 100 jin. (Xikang sheng nongye gaijin suo 西康省農業改進所, "Kangding chengxiang wujia diaocha 康定城廂物價調查," 1940, (SCDAG, QZH:249, AJH:33). 
A worse financial position in the late 1910s and 1920s also meant a greater need to collect more revenue locally. This was important for two reasons. Firstly, more taxation meant more official journeys for taxmen, which resulted in a greater demand for wula. Early Republican governments decided to increase their efforts to collect taxes from gold miners in Kangding, who were mostly Han Chinese and mostly paid very little tax. But the miners could only be surveyed and coerced into paying tax with the aid of wula services provided by the indigenous people. The locals pleaded in a petition to the magistrate that:

Also, if the gold miners run away, they [agents of the government] send us to catch them, this is on top of the regular corvée labour service. If the commissioners continue to do this, the people who undertake the labour service will be unable to bear the suffering it causes. ${ }^{46}$

In addition to needing more wula labour in order to collect more tax, Republican period county governments also increased other forms of taxation levied on livestock owners, as we saw in chapter three. Zhao Erfeng's government did collect some tax in cash from livestock owners. He had set the livestock tax at an annual rate of one Tibetan $j u$ (咀一one quarter of a Tibetan yuan) per horse or yak, or one ju per ten goats. ${ }^{47}$ However, he also stipulated that certain numbers of animals could be owned tax-free. These numbers varied from place to place, possibly depending on the wula burden. In Zhaya in Chamdo, those who owned less than thirteen yak equivalents were exempted from paying tax (one yak equaled one horse or ten goats) and households with more animals also did not have to pay tax on the first ten yaks, two horses, or ten goats. ${ }^{48}$ The rate per animal remained the same at least until the 1920s, but such exemptions appear to have

Price index in Xikang jingji jikan 西康經濟季刊, 1942, no.5-6 combined issue (5-6 hekan 合刊), 50.)

${ }^{46}$ SCDAG, Xikang caiwu choubei chu 西康財務籌備處, QZH: 206; AJH: 12

${ }^{47}$ QCBD, 3:734. See also JKDZ, 140-41.

${ }^{48}$ This was in 1910. In the same year in a different place, households were entitled to one tax-free horse, two tax-free yaks and ten tax-free goats. QCBD, 836. 
disappeared fairly quickly after $1911 .^{49}$ Assuming that an average man ate around $225 \mathrm{~kg}$ of barley equivalent per year, Zhao's reduction in the livestock tax would have been equivalent to more than five percent of the cost of a man's annual diet. ${ }^{50}$ In addition to this, as we saw in chapter three, many Republican period counties implemented and then frequently increased the butchery tax (tushui 屠稅). ${ }^{51}$ How exactly this affected livestock owners is unclear, though hefty taxes on slaughter of animals for meat likely had some impact on livestock owners.

Around 1938, the national Chinese currency (fabi 法幣) entered a period of high inflation and then hyperinflation. The effect of this on wula is difficult to clarify, because the 1936 regulations stated that the wula payments were to be made in Tibetan yuan, which had been steadily devalued throughout the Republican period but was not subject to the same hyperinflation as the fabi. ${ }^{52}$ This caused consternation among officials, who noted that by 1940 the market value of the two currencies was approximately equal, despite government attempts to fix the exchange rate at the old rate of one Tibetan yuan to $.45 \mathrm{fabi}^{53}$ The failure of such attempts and the rapid increase in the value of the Tibetan yuan relative to the fabi caused equivalent increases in the wula costs of officials who primarily used fabi. This prompted Zhang Zhen'guo to argue that wula payments should be made in fabi, which was after all the national currency of China. Zhang was

\footnotetext{
${ }^{49}$ See $J K D Z, 150-56$.

${ }^{50}$ One source puts the cost of a $300 \mathrm{~kg}$ guan shi 官石 of barley in Kham at 42 Tibetan yuan in 1915 (JKDZ, 85-86).

${ }^{51}$ The tax rate of the butchery tax varied from county to county. In some counties the revenue from the butchery tax was less than that from the livestock tax, in some it was similar, while in Kangding the butchery tax brought in more than five times what the livestock tax did. See Chuanbian caizheng ting 川邊財政廳, "Ge xian liangshui diaocha biao 糧稅調查表," 1932, (SCDAG, QZH:197, AJH:42).

${ }^{52}$ On the republican period increase in the supply of Tibetan yuan, see Zhong $\mathrm{Mu}$ 钟穆, "Minguo shiqi de Zangyang zhuzao 民国时期的藏洋铸造," in Ganzi Zhou wenshi ziliao, no. 14 甘孜州文史资料, 第十四辑, ed. Zhongguo renmin zhengzhi xieshang huiyi Ganzi Zangzu zizhizhou weiyuanhui 中国人民政治协商会议甘孜藏族自治州委员会 (Kangding: Kangding xian yinshua chang, 1996), 72-87; Yang Jianwu, "Minguo shiqi kangqu de jinrong caizheng."

53 Zhang Zhen'guo, "Feichu Kang qu wula zhidu jianyi shu," 131.
} 
also convinced that the Tibetan yuan denominated wula prices in the 1936 regulations should be converted according to the old "official” exchange rate. From the perspective of a peasant who primarily used Tibetan yuan, such a conversion of wula payments in 1940 would have been a disaster. But as a report by the China Agricultural Bank noted, most Xikang local authorities continued to use Tibetan yuan rather than fabi for all their business, so it is unclear whether or not the fabi hyperinflation had much effect on wula providers. ${ }^{54}$

Taking into consideration inflation and the flow-on impacts of diminished outside funding, even if the allegations that the Republican period authorities were more corrupt than Zhao Erfeng's regime are exaggerated, it is safe to conclude that the wula problem really was more serious in the Republican period than in the Qing.

Republican Period Responses to the Wula Problem, 1911-1930.

By the 1930s it had become clear that automobiles would one day be able to play some role in fixing the wula problem. However, given the difficulties Xikang's terrain presented for road construction, and the government's financial situation, observers agreed that it would be a long time before motorized transport could replace pack-animals on even the main routes. A complete end to pack-animal transport was often dismissed as impossible. ${ }^{55}$ Broadly, two types of solution to the associated problems were attempted. Firstly, governors throughout the Republican period followed the same strategy as Zhao Erfeng: ameliorating livestock owners' burdens with regulation and payments. The second solution, first attempted in 1932, was to create a state owned farm system to supply pack animals for government transport.

Early Republican governors adopted the former strategy and added still more articles to the already comprehensive code bequeathed to them by

\footnotetext{
${ }^{54}$ Zhong Mu, "Minguo shiqi de Zangyang zhuzao," 83.

${ }^{55}$ See Jiang Junzhang, "Wula wenti zhi jiejue tujing," 32.
} 
Zhao. Chen Xialing, who held the early Republican post of Sichuan Frontier Garrison Commander between 1917 and 1924, ordered the abolition of the 'broth service' (tang yi 湯役), according to which officials could demand food and hot water prepared for them, as well as the 'general service' ( $d a$ yi 打役), according to which peasants were required to care for private horses and perform other miscellaneous services. ${ }^{56}$ This prohibition was obviously not successful because later Republican writers described both of these services as part of current practice. ${ }^{57}$ Despite this-and despite the apparent neglect of most other wula regulations-new rules were frequently formulated. A code created by the command of the Twenty Fourth Army in 1929 was lengthier still than Zhao Erfeng's. ${ }^{58}$

It is debatable how effective such codes would have been in alleviating the burden of wula on peasants, even if they had been rigorously enforced. Regulators had an obvious conflict of interests because, as the military leadership, they were also the primary users of wula corvée. A tension between the two aspirations of ensuring a reliable supply of pack-animals and giving peasants a minimum standard of protection is evident in a lot of writing by magistrates and governors. Zhu Zengyun, 朱增釷an early Republican magistrate of Dawu, wrote of peasants who had fled from the corvée: "I have sent the village head to conduct a search. My orders are that if he should encounter them, he is only permitted to kindly persuade (shanquan 善勸) them to return, and may not force them to do so."59 One wonders how the village head interpreted the orders, and where the limits of "kindly persuasion” were. This tension is also manifested in the regulations. In addition to not raising payments, some articles contained vague,

\footnotetext{
${ }^{56} \mathrm{JKDZ}$, 199. Chen's prohibition of tang yi and da yi are referred to in a memorial written in 1928, I have not seen the original prohibition. The 1928 memorial was also published in Huang Shangcheng, "wula chaiyao zhidu zhi shi," 32-33. Concerning these services, Zhao's 1911 code had stated: “The tang yi, da yi and human porter (背夫 beifu) services generally fall upon the women among the barbarians (man min 蠻民). From now on, whether the services be performed by men or women, the person in question must be over fifteen and under fifty." (Article thirteen).

${ }^{57}$ Jiang Junzhang, "Wula wenti zhi jiejue tujing," 17.

${ }^{58}$ See JKDZ, 200-02.

${ }^{59}$ Zhu Zengyun, "Chuanbian zhengxie," 148-49.
} 
convenient get-out clauses. One stipulated that county magistrates had to be notified three days in advance of a "small corvée" requirement and ten days in advance of a "large corvée" requirement. However, the regulation also stated that this did not apply in any unnamed "special circumstances", ${ }^{60}$ Notification in advance was important, because, as Republican administrators often noted, wula burdens were much heavier on some communities because of their location near roads, but to spread burdens more evenly magistrates needed time to arrange for the duty to be levied on further away places.

Indeed, the rearrangement of wula burdens to spread the load more evenly was another form of response undertaken by Republican leaders to deal with the problem. In the 1940s, a Dawu magistrate wrote an argumentative article which illustrated the use of such a tactic.

In 1917, because there were many troubles on the southern roads and corvée burdens in Kangding were heavy, [the then Sichuan Frontier Garrison Commander] Chen Xialing 陳遐齡 [1873-1950] temporarily granted to Kangding the power to levy corvée from Chaba [which had been in Dawu]. However that was a long time ago and things have changed since then, but Chaba's corvée is still levied by Kangding. In fact they do not contribute any animals, but only pay a monthly fee of 1,200 yuan to the county government. [...] Now Chaba's corvée should return to Dawu [...] to reduce the heavy burden on the Dawu people. ${ }^{61}$

To support his argument further, the writer also referred to the redrawing of other boundaries in Xikang for similar pragmatic reasons, and pointed out that the Ning and Ya regions had been assigned to Xikang to assist the provincial government to pay its bills. The process of redrawing boundaries almost certainly contained an element inter-county turf-war in addition to any concern for tax-payers. Both of the Dawu magistrates quoted here complained about the bullying, unilateral behavior of Kangding magistrates. ${ }^{62}$ Sometimes this may have made the wula problem worse.

\footnotetext{
${ }^{60} \mathrm{JKDZ}, 200-02$.

${ }^{61}$ Wang Zhuo 王卓, "Daofu wula neimu jiqi zhengli yijian 道孚烏拉內幕及其整理意見," Kangdao yuekan 康导月刊 2, no. 5 (1940): 151.

${ }^{62}$ See also Zhu Zengyun, "Chuanbian zhengxie," 122.
} 
Villages may have sometimes been assigned to jurisdictions for political reasons even though their wula resources were less important to the new jurisdiction than the old. However, efforts to rearrange the levying of wula were probably not entirely unsuccessful. Nor did the rearrangement of wula duties have to take the form of a redrawing of county boundaries. Zhu Zengyun, for example, arranged matters so that inbound and outbound traffic took different routes and thereby imposed on different villages. ${ }^{63}$

War in Kham and Solutions to Wula in the 1930s.

Despite the general worsening of the situation in the Republican period and the problems with the solutions attempted before 1930, the system could possibly have limped on without facing any major crises if war and the concomitant military campaigning could have been avoided. However, when the Pehru-Targye (Ch. Baili-Dajin) monastery conflict broke out in 1930, the forces of Lhasa and Liu Wenhui joined in on opposite sides and the fighting escalated into a war that involved up to 20,000 fighters (see chapter one). With the help of the Qinghai warlord Ma Bufang, Liu embarked on a vigorous campaign that saw the Lhasa army beaten back to the Yangtze by summer 1932. The cost of this campaign was huge for the wula providers. By the Frontier Defense Force leadership’s own admission, war related traffic increased the demand for wula by roughly ten times what it normally was. ${ }^{64}$ Faced with the danger of being unable to supply armies at the front, Liu Wenhui attempted the second solution for the wula problem identified above. In August 1932, he tasked Brigade Commander Yu Songlin余松琳 with establishing a State Wula Agency (Guan yun wula shiwusuo 官運烏拉事務所). The Agency’s provisional constitution (shiban zhangcheng 試辦章程) ordered every county magistrate to organize a local office and a certain number (to be determined by the army) of encampments

\footnotetext{
${ }^{63}$ Ibid., 123.

${ }^{64} \mathrm{JKDZ}, 204$.
} 
(zhang 帳). ${ }^{65}$ Each encampment was to purchase 100 yaks from the nearby pastures at “approved prices” (heding jiage 核定價格). These yaks were to be used for nine to twelve outward supply journeys in the six months from April through September (the busy season for official transport). On return journeys and in the case that official demand for transport was low they were to provide a commercial transport service which would help pay for the Agency's costs. It seems unlikely that the Agency could have made much money in this manner because transport rates going from west to east were very cheap in comparison to the other direction (see chapter six). This was not the only difficulty facing the Agency, however, and the scheme was a failure. Many animals died from sickness and exhaustion and the organization was wound up within a year, after more than twenty thousand Tibetan yuan had been spent on it. ${ }^{66}$

The root problem or problems are unclear. It appears from Frontier Defense Force records that the number of livestock actually bought was much less than the amount that the provisional constitution had envisaged. The records may be incomplete but the total cost given, 19,521 Tibetan yuan, tallies with the twenty thousand that $\mathrm{Hu}$ Xiaomei says was spent in total. ${ }^{67}$ The documents show the purchase of 68 mules, 38 horses and 86 bovines-mostly dzo, the Tibetan yak-cattle hybrid (Ch pianniu 犏牛), as well as equipment and tents. ${ }^{68}$ The prices paid were thus relatively high, an average of 51 Tibetan yuan per bovine or 155 yuan per mule. It is difficult to know how close these prices were to what would have been paid by purchasers who lacked an army to strengthen their bargaining position. The purchasers indicated that they had initially planned to buy 360 bovines, but due to the effects of a cattle pestilence (niu wen 牛瘟) the price of these animals was very expensive, and the horses and mules were bought instead.

\footnotetext{
${ }^{65}$ Ibid., 204-06.

${ }^{66}$ Hu Xiaomei, "Liu Wenhui Kangqu wula zhidu gaige shulun," 37.

${ }^{67}$ Ibid.

${ }^{68} \mathrm{Hu}$ Renji 胡人紀, "Chengwei zunling huitong dianyan guanyun wula zaoce jicheng yangqi 呈為尊令會同點驗官運烏拉造冊齊呈仰祈," Chuan Kang bian fang jun 川康邊 防軍, (SCDAG, QZH:24, AJH:4).
} 
If this were the case, then the purchasers were not able to dictate prices to the sellers. In 1939, Ren Naiqiang reported that a mule cost around 100 dayang yuan (roughly 225 Tibetan yuan). ${ }^{69}$ Taking inflation between 1932 and 1939 into account, the price paid by the Agency for mules in 1932 seems fairly reasonable. Certainly the prices were higher than the compensation mandated by the 1929 code for dead animals, which was 30 Tibetan yuan per bovine. On the other hand, it is possible that these prices were not paid at all, some of the money being embezzled by the purchasers. One of the purchasers, a magistrate called Wu was indeed later found to have misappropriated Agency funds. ${ }^{70}$ However, those charges related to another matter, and in addition to the purchasers' note about disease, other sources also mention livestock disease in Kham at various times in the Republican period, so the charge that this was responsible for some of the Agency's problems is not implausible. ${ }^{71}$

The reasons for the death of its livestock are also unclear. It could have been due to one or a combination of the following: negligence in the treatment of the animals by the Agency, a general disease affecting livestock in Kham, or the fact that the animals may have been sick and old to begin with. These problems would have been exacerbated by the extraordinary demand placed on the system in 1932 when Liu's forces in Kham attempted to rapidly redeploy from Bathang back to the Sichuan basin after the start of the "Two-Liu War". Petitioners from Dawu, who were protesting against the army's later demand that they repurchase the exhausted surviving animals (at the prices that were recorded by the purchasers), blamed all these factors for the deaths. ${ }^{72}$ (Tactfully, they referred to the redeployment of Liu's troops as a "triumphal return").

\footnotetext{
${ }^{69}$ Ren Naiqiang, "Luding kaocha ji 泸定考察记," in Minzu yanjiu wenji 民族研究文集, ed. Ding Shihao 丁师浩 (Beijing: Minzu chubanshe, 1990), 114.

${ }^{70}$ Hu Renji, "Chuan Kang bian fang jun," Chuan Kang bian fang jun, (SCDAG, QZH:24, AJH:4).

${ }^{71}$ See Xikang sheng linshi canyihui 西康省臨時參議會, di er jie, di yi ci da hui huibian 第 二屆第一次大會匯編 (1942), p. 32; Coales, "Narrative of a Journey from Tachienlu to Ch'amdo and back via Batang," 208; Meng Yongxi 蒙永锡, "Shiqu xianzhuang sumiao 石渠现状素描," Kangdao yuekan 康导月刊 2, no. 8 (1940): 64.

${ }^{72} J K D Z, 208-09$.
} 
Without more information on this question, it is difficult to evaluate and contextualize the later explanations of the Agency's failure. These tended to focus on negligence and ill treatment of the animals, which they blamed on poor organization, as we shall see below.

The disappointment of the Agency did not prevent other attempts at establishing alternative transport institutions. In 1935 and 1936, at least three journals on frontier affairs published Ren Naiqiang's ambitious plan for a Sichuan Frontier Crop and Pasture Company (Chuanbian ken mu gongsi 川邊墾牧公司). ${ }^{73}$ At this time, Ren was a member of the Preparatory Committee of Xikang Province. According to the plan, the company would earn most of its income in the tea trade, but, in addition to engaging in almost every kind of agriculture possible in the region, would also undertake wula services for the government. ${ }^{74}$ It is unclear whether Ren imagined that this would be in return for government investment, or if his argument was that a profit could be derived from contracting the source of peasants' hardship. The plan became a reality a couple of years later with the establishment the Xikang Animal Transport Company ( $M u$ yun gongsi 牧運公司) in $1938 .^{75}$ The only information I have seen on its ownership and management structure is in criticisms written after it was wound down a few years after it was established, from which it appears to have been a wholly state owned and operated enterprise. ${ }^{76}$ There is less doubt about its fate, which was more or less the same as that of the State Wula Agency. The livestock-more than one thousand head this time-died en masse and

\footnotetext{
${ }^{73}$ Ren Xiaozhuang 任篠莊, "Chuanbian ken mu gongsi jingying shiye jihua 川邊墾牧公司 經營事業計劃," Chuanbian jikan 川邊季刊 2, no. 2 (1936)., also published in Sichuan nongye 四川農業 2, no.4 (1935): 20-27 and Kang-Zang qian feng 康藏前鋒 3, no.7 (1936): 33-40. It is according to Josef Kolmas that Ren Naiqiang sometimes used the penname Ren Xiaozhuang: Josef Kolmas, Chinese Studies on Tibetan Culture: a Facsimile Reproduction of the K'ang-Tsang Yen-chiu Yüeh-k'an (Hsik'ang-Tibet Research Monthly) (New Delhi: International Academy of Indian Culture, 1983).

${ }^{74}$ Ren Xiaozhuang 任篠莊, "Chuanbian ken mu gongsi jingying shiye jihua 川邊墾牧公司 經營事業計劃," 166, 71.

${ }^{75}$ Wang Zhuo 王卓, "Daofu wula neimu jiqi zhengli yijian 道孚烏拉內幕及其整理意見," 153.

${ }^{76}$ Zhang Zhen'guo, for example calls it a 'guan ying shiye 官營事業’ Zhang Zhen'guo, "Feichu Kang qu wula zhidu jianyi shu," 134.
} 
within one year the company was dissolved, after more than one hundred thousand yuan had been spent on it. ${ }^{77}$

Discourse on regulation and innovation and their failures

By the 1940s a range of different solutions to the wula problem had been attempted. None of them resolved the issue and some were bitter disappointments that carried a large financial cost (in Xikang terms). In 1940 Kham Guide Monthly published a special issue on the wula problem, which, together with articles published in other frontier-orientated journals, was the site of a relatively vigorous exchange of ideas on the causes of the failures and what the next move should be. In explaining the problems with the first two attempts to establish an alternative transport institution most writers shared roughly the same opinion. Discussion focused mostly on the 1938 attempt rather than the earlier one. ${ }^{78}$ In his own brief article in the Kham Guide Monthly special issue Liu Wenhui explained:

The State Wula Agency and the Animal Transport Company both ended in failure. What is the reason that they did not work? The task of raising a large number of animals is a difficult one. Han people are several thousand years removed from nomadic life, and when they were put in charge of the animals, the livestock were not properly fed and looked after. This was the case with the Animal Transport Company, and all the animals died. When the Kham people were put in charge of them, they did not have a strong incentive to look after the animals. Thus they were lax and inattentive, and the animals were still not properly looked after. This was the case with the State Wula Agency, and all their animals died as well. ${ }^{79}$

These points were stated or expanded on by many writers. Zhang Zhen'guo, for example wrote that:

\footnotetext{
${ }^{77}$ Hu Xiaomei, "Liu Wenhui Kangqu wula zhidu gaige shulun," 37.

${ }^{78}$ Jiang Junzhang complained that there were no documents to explain the reasons for the failure of the State Wula Agency: Jiang Junzhang, "Wula wenti zhi jiejue tujing," 31.

${ }^{79}$ Liu Wenhui, "Xikang chaiyao zhi guoqu yu jianglai 西康差徭之過去與將來," Kangdao yuekan 2, no. 5 (1940): 5.
} 
In the counties beyond the pass, most people still live a nomadic life [...]. From their childhood to old age they live in close harmony with their animals [...]. Furthermore, yaks and horses are the people's living assets. For these reasons, they love and protect, raise and cherish their livestock, valuing them as much as their own lives [...] However, the Animal Transport Company, as a state operated enterprise, employed its staff as hired labourers. The livestock did not belong to the workers, and all the profits accrued to the state. The staff were frequently shuffled around [...] and none of them expected to be in their positions for long [...]. In such circumstances, how could we expect great devotion to the animals from them? ${ }^{80}$

Zhang wrote the most extensive critique of the Animal Transport Company, naming six failings that could be rectified and four that would be difficult to deal with - the problem of incentive was one of the latter. Like other writers, he showed a strong tendency to relate the problems to lack of knowledge of livestock as well as the scheme's organizational structure. Thus although he mentioned corruption, he saw it mostly as the result of these two factors. Managers were poorly trained and ill-equipped to deal with the large numbers of staff. Zhang also explained corruption as a general result of state ownership: "State enterprises are typically beset by the problem of employees using state funding for private ventures, and the Animal Transport Company was no exception.” 81 Politics may well have prevented Zhang from accusing the leadership of the company of anything more than naivety and poor planning, but he could possibly have addressed the problem of embezzlement at higher levels of the company by discussing the earlier State Wula Agency, given that Magistrate Wu was already a disgraced figure. Also, the lone hint that the company may have suffered from insufficient financial resources was his statement that there was a complete lack of veterinary medicine.

\footnotetext{
${ }^{80}$ Zhang Zhen'guo, "Feichu Kang qu wula zhidu jianyi shu," 134.

${ }^{81}$ Ibid.
} 
Wula solutions, indigenous leadership and the development of local government

In the Kham Guide Monthly special issue on wula, Liu Wenhui summarized the two main approaches to solving the wula problem; regulation on the one hand and an alternative transport system on the other. One could argue for both in the short term, but they were seen as mutually exclusive in the long run. The aim of an alternative transport system was the eventual abolition of the wula corvée. Those who argued for regulation tended to see an alternative transport institution as unfeasible.

The whole debate on wula served as a field for the development of viewpoints on the vital questions of what the state's relationship with indigenous leadership ought to be and what its role in society in general ought to be. The argument here is not that interpretations of the wula problem completely dictated officials' positions regarding these questions, but that viewpoints on the wula problem, indigenous leadership and the role of the state were mutually related. Furthermore, this discourse led to the development of practical agendas: ideas for concrete courses of action that the government should or should not undertake. Interpretation and discussion of the wula problem transformed what may otherwise have remained vague prejudices and notions into substantial programs that had real consequences for the Han-dominated local state's relationship with indigenous communities in particular, and its size and role in society in general.

Indigenous leaders were the key intermediaries within the existing wula system. Many officials believed that they were the reason for the problems with it. They accused the indigenous leaders of withholding payments the state made to wula providers and ignoring the regulations. Indeed such officials often pointed to the native leaders' power in the wula system as the reason for all the regional government's problems. Ren Zhuo wrote:

Although the authority to requisition wula in Kham in theory belongs to the government, the great power of raising wula is in reality wielded by the native headmen (tutou 土頭). The headmen of Kham dare to openly act according to their own whim, without paying attention to any rule or 
restraint. They hold the government in the palm of their hand and bully the people. They are stubborn and obstinate and make themselves a great obstacle for the government's rule. Indeed, with their great power over transport they are in control of everything (neng zuoyou yiqie 能左 右一切). ${ }^{82}$

Those, like Ren, who had an unambiguously negative view of the role played by indigenous headmen, argued passionately for the establishment of a transport institution that was wholly owned and operated by the state and could bypass this layer of obstreperous indigenous authority, depriving it of its power and ridding Xikang of what they deemed was the greatest threat to the smooth running of the government. Ren argued:

It is vital to first establish state managed (guanying 官營) animal transport in Kham, in order to thoroughly take control of transport ... [only thus] can the new administration of the Kham region develop smoothly. There is no other rational way forward. The obstreperous headmen know that state-managed transport is not in their interests and thus they oppose it, but their opposition must not cause the government to decline to take up the long neglected keys to power. ${ }^{83}$

Such writers probably had prejudices against indigenous leadership that were not caused by or related to the wula problem. However, their interpretation of the wula problem likely hardened and reconfirmed such prejudice. More importantly it led them to argue for the development of a major state owned enterprise; something that would have far reaching consequences for the nature of the state and for its relations with indigenous communities.

Prejudice was not necessarily the only reason for supporting the idea of a state-owned enterprise to replace wula. Wula-abolitionists probably also saw state-owned enterprise precisely as a way to make up local shortfalls using outside resources. The enterprise would be paid for with taxes that would be levied fairly and proportionally across all wealth in Xikang, as opposed to disproportionately on livestock owning peasants who happened to live near major roads. I have not, however, encountered a source that

\footnotetext{
${ }^{82}$ Ren Zhuo, "Wula zhidu yu guan ying mu yun," 17.

${ }^{83}$ Ibid.
} 
makes this point directly. Officials may have avoided making this argument explicitly for fear of causing offense by suggesting that places and people that currently paid little tax would have to pay more under their schemes. Ren Naiqiang's notion that a state-owned wula-replacing enterprise could actually make money would have been much more appealing than the idea that such an enterprise would require a greater extraction of wealth from the provincial well-off. ${ }^{84}$

There were a couple of reasons why some officials opposed the establishment of an alternative transport system and argued that it was better to ameliorate the status quo with regulations. Firstly, they believed that this solution was simply more likely to be successful than the establishment of the kind of enterprise described by Ren Zhuo. The politics of the broader national debate between proponents of private enterprise and supporters of state-owned enterprise exerted some influence here. The Frontier Administration Planning Commission (Bianzheng sheji weiyuanhui 邊政設 計委員會) for example, stated that “the experience of the Interior furnishes many examples of private enterprises whose achievements are much greater than government departments." ${ }^{\circ 5}$ Secondly, some opponents of a solution along the lines of what Ren Zhuo proposed had less negative views of indigenous leadership, or at least were less inclined to blame indigenous leaders for the wula problem. If the indigenous leaders were not the problem, then there was no need for the solution to be based on the principle of excluding them.

In my reading of the available sources, those who supported this kind of approach were less passionate and direct in their arguments than those in the 'new transport organization' camp. Nevertheless, it appears that after the end of the Animal Transport Company, Liu Wenhui veered towards maintaining and improving wula rather than replacing it. The failures of the new transport organizations seem to have convinced Liu that they were unviable, and as we saw above, he argued that no matter whether indigenous

\footnotetext{
${ }^{84}$ This is probably exactly why Ren proclaimed that it would generate income.

${ }^{85}$ Quoted in Zhang Zhen'guo, "Feichu Kang qu wula zhidu jianyi shu," 135.
} 
or Han employees were used, the animals would inevitably be neglected. Perhaps mindful that many of his officials continued to support a state enterprise solution, Liu did not categorically rule out this option. But he did go on to write:

It is impossible not to use the Kham people and their animals, because only the Kham people have a large enough number of animals and only the Kham people have the skills to look after them. [...] If we would decrease the suffering that corvée brings to them, and even bring to them some small benefit, it is necessary to implement some regulations. ${ }^{86}$

While Ren Zhuo and others argued passionately for the abolition of wula, Liu Wenhui was averse to this idea, even in exceptional situations that would not have greatly affected government transport. When a small airstrip was built near Kangding, five families who were evicted from their land petitioned to request exemptions from tax and wula. Liu's response was that compensation for the lost land could be granted, as well as an exemption from the land tax, but the corvée duty would still have to be met. ${ }^{87}$

Consistent with Liu's preference for the maintenance of wula, the available evidence suggests that Liu Wenhui was less averse to working with indigenous leadership than many in his administration. In his 1939 inaugural address as the chairman of Xikang province, he stated:

Those [natives] that have ability, learning, or are virtuous and highly esteemed; they should at all times be selected for appointment, and be made to participate in the politics of this province. ${ }^{88}$

Ren Zhuo's thundering attack on the headmen certainly did not suggest that among them were leaders who were virtuous or possessed of learning and suitable for posts within the provincial administration.

This does not mean that we should characterize Liu and those who proposed a regulatory system as being pro-indigenous in general. As this

\footnotetext{
${ }^{86}$ Liu Wenhui, "Xikang chaiyao zhi guoqu yu jianglai," 5.

${ }^{87}$ Liu Wenhui, correspondence with Kangding officials, 1940, Xikang sheng caizhengting 西康省財政廳 (SCDAG, QZH:207, AJH:1).

${ }^{88} \mathrm{JKDZ}, 75$.
} 
solution required greater links between indigenous leadership and the Han state, it left less room for indigenous autonomy. Indeed those who favoured this approach sometimes put forward the broader mission to assimilate the indigenes as a reason to adopt it. The Han-ization (Hanhua 漢化) of the indigenes could only proceed if there were strong contacts between the indigenes and the Han government, they reasoned. Given that the wula system was the primary point of contact between the two (in some cases the only point of contact) it was necessary to maintain it just so it could serve this purpose. Wang Zhuo王卓argued for Dawu corvée duties to be levied on people in Chaba (Kangding), and stated that it would "make the Chaba people accustomed to Han-ization (xi yu Hanhua 習於漢化), and come into more substantial contact with the government." ${ }^{89}$ As we shall see in chapter seven, one of Liu Wenhui's broad aspirations was to encourage the assimilation of the indigenous population (though we shall also see that what he meant by "assimilation” is somewhat unclear). In the sources used by this study, however, he did not make the argument that wula ought to be retained as a tool to serve this end, so whether his views on assimilation affected his policy on wula remains a matter of conjecture. The idea of retaining wula for this purpose was roundly criticized by opponents like Zhang Zhen'guo, who pointed out that contact between the people and government should be based on the principle of improving their happiness. ${ }^{90}$

There was perhaps a compromise position in the form of proposals for a new transport institution that was privately owned and operated-with some government investment or oversight-and inclusive of substantial indigenous co-ownership and management. This would have entailed a significant and legitimate space for indigenous leadership within the key institutions of the new Xikang society. Jiang Junzhang argued for such an organization, as did the Frontier Administration Planning Commission (Bianzheng sheji weiyuanhui 邊政設計委員會) of the Military Affairs Commission Headquarters during a 1937 All-Kham Conference on

\footnotetext{
${ }^{89}$ Wang Zhuo, "Daofu wula neimu jiqi zhengli yijian," 152.

${ }^{90}$ Zhang Zhen'guo, "Feichu Kang qu wula zhidu jianyi shu," 139.
} 
Corvée. ${ }^{91}$ Jiang Junzhang suggested giving the indigenes shares in the company equivalent to the value of the animals that they had provided — so that they were the main shareholders. He presumably saw this as the key to having a workforce that not only knew how to look after animals, but had the incentive to do so as well. ${ }^{92}$ The Planning Commission argued that "the planning of this organization will be undertaken cooperatively by the Commission for the Establishment of Xikang Province, the Chamber of Commerce, those lamas who are held in high esteem locally, the tusi and representatives of pack-animal transport teams of the high pastures.”93

This sort of proposal was often criticized for being based on unrealistic assumptions about indigenous people and society. Yang Zhonghua-one of the Chinese observers who was more familiar with the indigenous peopleargued against it. Yang is reported to have said that "None of the Xikang natives would be willing to offer their precious and limited livestock in order to organize a company that is totally unfamiliar to them." ${ }^{94}$ Zhang Zhen'guo also quoted several indigenous leaders who apparently argued that it would be difficult or impossible for them to take up roles in the management of such a company due to their nomadic lifestyles. Widely believed to be unrealistic - and doubtless unattractive to those who held that the indigenous leadership was the key problem anyway - this kind of proposal does not appear to have been well supported.

The Lasting impact of wula on the development of the Chinese state

The government and military demand for wula had a huge impact on some herding households, but what kind of impact did it have on the state? The supporters of state-enterprise never saw their proposals come to fruition.

\footnotetext{
91 The Planning Commission proposal, and the criticism of it, is discussed at length by Zhang Zhen'guo.

92 Jiang Junzhang, "Wula wenti zhi jiejue tujing," 33.

93 Zhang Zhen'guo, "Feichu Kang qu wula zhidu jianyi shu," 135.

${ }^{94}$ Quoted in Ibid.: 136.
} 
Nevertheless, advocacy for this position and the experiments that it generated made a significant contribution to the development of the Chinese regional state in Kham. Arguably, it was one of the key reasons for the recalibration of government agricultural policy toward livestock farming initiatives and away from the Qing policy of supporting crop farming.

As we have noted already Ren Naiqiang, the architect of the Animal Transport Company, was also a member of the Preparatory Committee of Xikang Province. In 1937 the Commission had founded the Taining Experimental Zone (shiyan qu 實驗區). One of the key undertakings within the Experimental Zone was a government managed livestock ranch, which was presumably established in preparation for an Animal Transport Company. Unlike the company, the ranch did survive, and was later put under the management of the Agricultural Institute. It was the largest and best funded state owned agricultural enterprise in Xikang, receiving 37 percent more investment than the second most highly funded single enterprise listed in the available sources. ${ }^{95}$ In 1943, there were 1,245 bovines, 188 horses, 263 lambs, 120 sheep and 127 pigs on the farm. ${ }^{96}$ According to the historian Wang Chuan, the farm covered almost 2.5 million $m u$, or around 1,680 square kilometers. ${ }^{97}$ One report refers to some of the ranch's bovines and horses as "wula” animals. It is unclear whether this meant that these were animals raised by the ranch to provide wula services, or whether they were wula animals provided free of charge by locals, to be used in the service of the farm itself. ${ }^{98}$ In 1955 the ranch was combined with the Agriculture Institute's Kangding farm to form the Kanze Tibetan Autonomous Prefecture Experimental Agriculture Station 甘孜藏自

\footnotetext{
${ }^{95}$ Liu Yiyan 劉貽燕, "Wu nian lai Xikang nongye jianshe zhi huigu 五年來西康建設之回 顧," Xikang jingji jikan 1, no. 8 (1944): 5-6. Liu’s figures give one total amount of funding for all the operations managed by the Ningshu office of the XAII, which was slightly more than the Taining ranches total funding.

${ }^{96}$ Dao Xue 稻雪, "Xikang Taining shiyanqu diaocha 西康泰宁试验区调查," Xin Kang bao 新康报 1, no. 2 (1938), reprinted in Kangqu Zangzu shehui lishi diaocha ziliao jiyao, eds. Zhao Xinyu and Qin Heping, 213.

${ }^{97}$ Wang Chuan, "Minguo hou qi 'Xikang sheng nongye gaijin suo’," 65.

98 Dao Xue, "Xikang Taining shiyanqu diaocha," 213.
} 
治州农业试验站. ${ }^{99}$ Since then it has undergone several other changes to its name and character, but has remained in existence to the present day. In this way, the wula problem, or rather one attempted solution to the wula problem, made a significant contribution to the development of large stateenterprise in Kham.

Despite such efforts, wula was not abolished until well into the socialist period. Like the state-enterprise solution, the attempt to regulate the system also had a significant effect on the development of regional state authority. It led to more closely managed relationships between the regional state, local agents loosely associated with the state, and indigenous non-state authorities than would probably have been the case otherwise. In this respect, state development in Kham was significantly different from the state involution that, in Prasenjit Duara's view, took place in northern China. ${ }^{100}$ In the latter region, formal state structures grew simultaneously with informal state structures. The surplus extracted from villages massively increased, but was divided between the formal state and the 'entrepreneurial brokers' who collected taxes for it but existed outside its control. For our purposes, one of the most important features of this type of state development was that it began in an environment in which taxes were extremely low; hence there was space for multiple forms of authority to grow without cannibalizing each other.

In Kham, the labour surplus that could be extracted as corvée was so limited in some places that involutionary growth was unlikely or impossible; it was difficult for one form of authority to grow without impeding another. The problem was not merely that the number of people and animals was limited. It was also easier for these people to run away from the taxmen than it was for, say, villagers in northern China. As we have seen, the provincial government attempted to obviate this problem by sourcing its transport elsewhere. Before this solution was attempted and after it failed, the impossibility of involutionary growth had two

\footnotetext{
${ }^{99}$ Wang Chuan, "Minguo houqi 'Xikang sheng nongye gaijin suo’," 69.

${ }^{100}$ Prasenjit Duara, Culture, Power, and the State: Rural North China, 1900-1942

(Stanford: Stanford University Press, 1988), 73-75.
} 
consequences. Firstly, it encouraged conflict between different forms of authority, and between the regional government and its local associates over the limited surplus that could be extracted from communities as corvée labour. Secondly, when one party failed to gain the upper hand in such conflicts, it led to detailed divisions of the taxable households between different wula-controlling authorities. Relationships between such authorities came to be precise, legalistic and highly managed.

Entrepreneurial brokers existed in Kham, but they were often squeezed out of the picture by a more formalized local bureaucracy that was jealous of the surplus they extracted from local communities. Chapter one introduced one prominent early Republican frontier strongman in Dawu County, who was known as "Barbarian King Ding” (Ding Manwang). ${ }^{101}$ Ding did not have an official position in the Chinese bureaucracy, but he was in charge of the local militia and also clearly had the power to arrange the corvée duties. He abused this authority by exempting militia members from wula, and reportedly made more than 10,000 yuan by charging a fee for the privilege of joining the militia. From a certain perspective, there was a rationalizing tendency here. He had essentially converted the corvée labour tax into a tax paid in money, a move that was entirely consistent with long-term trends in taxation throughout China. Ding's downfall came when he was sued twice, once by a Han merchant and once by locals who had learned that it was government policy to pay for wula corvée labour. The Xikang Special Administration Committee sided against Ding, and forced him to cough up some of the wealth he had amassed and let go some of his authority. Despite Ding's success at defending Han authority against the lamas, it was not surprising that the Special Administration Committee sided against him. His income did not merely represent foregone income for the local administration, but actually depleted the capacity of the local state. It meant that fewer households performed the corvée, and in Dawu the primary limitation on state growth was the lack of available corvée labour.

Local governments' relations with indigenous communities were also affected by the wula regulations. Having created them, authorities were

${ }^{101}$ Ren Naiqiang, Xikang tujing: minsu pian, 263. 
bound to at least attempt to ensure that they were enforced. This entailed a certain amount of policing of indigenous leadership and communities that would otherwise not have been necessary. Wula payments had to actually reach the peasants, and burdens had to be shared throughout a community. To this end, Liu Wenhui also established a corvée supervisory system (jiancha zhidu 監察制度), which saw supervisors posted at key locations with the aim of watching over county magistrates and tusi to ensure their compliance with regulations. How much impact the wula supervisors had is unclear, but their existence increased the presence of Han bureaucracy in Tibetan communities. At least one of the pre-1930 wula codes had contained an article mandating that it be translated into Tibetan and distributed to "all the villages" in the Kham administrative region. ${ }^{102}$ Again, it is unclear to what extent this was actually carried out, but Liu Wenhui also stressed the importance of this in his discussion of the problem in 1940. ${ }^{103}$ Wula users also had to have a good idea of the livestock resources of each settlement and for this purpose the regional government ordered extensive surveys of livestock holdings.

Government policy relating to wula also created other unexpected entanglements and connections between local Chinese authorities and indigenous communities. Zhu Zengyun described a dispute between a mill owner and his tenant. ${ }^{104}$ As part of the rent, the tenant had agreed to undertake the landlord's corvée service. When Chen Xialing exempted the local lamasery from the corvée (we presume that the landlord was connected to the lamasery), the deal looked bad for the landlord, and he demanded the property back. Zhu's account of the case gives the impression that the dispute was resolved by his own judiciousness. One imagines that an indigenous authority could have dealt with it just as well. Nevertheless, both the plaintiff and the defendant in the case presumably had made every effort to understand the government's policy concerning wula and anticipate any future changes as the value of their deal depended on such calculations.

\footnotetext{
${ }^{102}$ Yang Zhonghua, Xikang ji yao, 295-96.

${ }^{103}$ Liu Wenhui, "Xikang chaiyao zhi guoqu yu jianglai," 4.

${ }^{104}$ Zhu Zengyun, "Chuanbian zhengxie," 118-19.
} 
Thus local communities did not merely passively respond to governments' demand for corvée (or run away). They were in a position of having to actively gather information about changes in policy and future levels of demand. This also boosted interaction between the government and local communities beyond what would have been the case with a more predictable and less problematic tax.

Where local Han governments were unable to completely control the supply of wula labour, their relationship with other local authorities, such as monastic estates and chieftains, tended to be structured around a detailed and legalistic separation of the tax base. When Chen exempted serfs attached to the large lamasery in Dawu from providing corvée for Chinese officials, Zhu Zengyun requested several times for the exemption to be lifted. In one report, he listed the families and animals that provided corvée service for his county government, as well as those that did the same for the lamasery. ${ }^{105}$ In the magistrate's view the latter lived lives of idleness, but one supposes that the lamasery found work for them to do. His letter demonstrates that every livestock owning family and their animals was explicitly identified as belonging either to the magistrate or the lamasery. To a large extent, the trilateral relationship between these two parties and Chen Xialing, the Garrison Commander, was structured around an ongoing, legalistic dispute about the apportioning of this tax base.

\section{Wula and the Ganzi conflict}

In Dawu, this tension appears never to have escalated further than a military stand-off. There is, however, evidence that this kind of dispute was partly responsible for the much more serious 1939 Kanze conflict. The sources used by this study do not permit a firm conclusion that the wula problem was the primary cause of the conflict. But the brief narratives that have been given by scholars do not satisfactorily explain the events either: there is a

${ }^{105}$ Ibid., 124. 
piece or two of the puzzle missing, and it is quite likely that wula was one of them.

The dramatic events of the Kanze conflict have been the subject of several brief scholarly accounts that differ significantly in terms of emphasis and interpretation. ${ }^{106}$ Following, I give a brief summary of the events and the dominant explanation of them, then present the case that the wula problem was one significant factor in the build up to the conflict.

From 1924 the Panchen Lama, a "pro-Chinese" Tibetan theocrat, was resident in Inner Mongolia. ${ }^{107}$ In December 1933, the 13th Dalai Lama died, and the Panchen began a journey back to Tibet, apparently seeing an opportunity to wield temporal power there. ${ }^{108}$ He received strong support from the Guomindang in the form of a well armed field office with three hundred soldiers, as well as a series of honorific titles including membership in the Supreme Council. ${ }^{109}$ The Chinese mass media pinned great hopes on the Panchen's return cementing Tibet's position within the Chinese republic. ${ }^{110}$ There is some debate, however, about the Guomindang's motives. Hsiao-ting Lin suggests that Party secretly worked to keep the Panchen in Qinghai, believing that he was more useful there than in Lhasa. ${ }^{111}$ Whether he was stalled by the machinations of the Guomindang, or by a Lhasa government opposed to the return of a "pro-Chinese" leader,

\footnotetext{
${ }^{106}$ See Lin, Tibet and Nationalist China's Frontier, 89-119; Peng Wenbin, "Frontier Process," 72-74; Huang Tianhua 黄天华, "Liu Wenhui yu Ganzi shijian 刘文辉与甘孜事 件," Xinan minzu daxue xue bao (renwen sheke ban) 西南民族大学学报 (人文社科版), no. 3 (2009); Zhang Jian 张践, "Ban yuan fan Zang yu "Ganzi shibian" 斑辕返藏与“甘 孜事变”," Qinghai minzu yanjiu 青海民族研究 18, no. 4 (2007).

${ }^{107}$ Lin, Tibet and Nationalist China's Frontier, 88-89.

${ }^{108}$ Ibid., 89.

${ }^{109}$ Ibid.

${ }^{110}$ Ibid.

${ }^{111}$ Probably the simplest explanation of the Guomindang's motives is that they hoped, like the Chinese media, that with their ally the Panchen Lama wielding power in Lhasa, relations between themselves and Lhasa would improve and the danger of de jure Tibetan independence would subside. Less conventionally but with good evidence, Hsiao-ting Lin argues that the Guomindang was "merely using the Panchen Lama as an instrument to introduce their influence into the border regions and to deal with Chiang Kai-shek's rivals in the mid-1930s -- primarily the semi-independent warlord regimes and the Communists.” In this interpretation, Chiang was using the Panchen as a tool to deal with the likes of Liu Wenhui and Ma Bufang, rather than the situation in Lhasa. Ibid., 92-110.
} 
the Panchen died, frustrated, in Qinghai on 1 December 1937. The field office moved to Kanze in $1938 .{ }^{112}$ According to the office, food supplies were dangerously low in Yushu and the post-mortem preservation procedures to be conducted on the Panchen's body could be performed more readily in Kanze. ${ }^{113}$

On 25 December Wu Zhongxin 吳忠信 (1884-1959), the director of the Guomindang Commission on Mongolian and Tibetan Affairs (Meng Zang weiyuanhui 蒙藏委員會), wrote to Chiang Kai-shek suggesting that the office move on to Kangding. ${ }^{114}$ Liu Wenhui also urged the field office to come to Kangding, probably hoping that there his government would be able to take control of the resources heaped upon the office by the Guomindang. The field office rejected the invitation. In March 1938, the Guomindang dispatched Zhao Shouyu to repossess the field office's weapons. However, the office was unwilling to disarm and Zhao was unable to force it to comply.

Sources written after the conflict state that Liu Wenhui's Xikang government now began hearing frequent "rumours" that the Guomindang was planning to separate the northern Kham counties from Xikang and create a special administrative region under the authority of the field office, which would report directly to the central government. ${ }^{115}$ It is highly improbable that the Guomindang was planning anything of the sort. Firstly, this would be inconsistent with Wu Zhongxin's proposal that the office go to Kangding. Secondly, it would also seem inconsistent with the attempt to disarm the field office. Thirdly, after the start of the fighting between Liu Wenhui and the Panchen's field office, the Guomindang expressed support for Liu Wenhui. ${ }^{116}$ Finally, there are no examples of the Guomindang actually creating new administrative regions and then bequeathing control of

\footnotetext{
${ }^{112}$ Zhang Jian, "Ban yuan fan Zang yu "Ganzi shibian"," 118.

113 JKDZ, 460; Zhang Jian, "Ban yuan fan Zang yu "Ganzi shibian"," 118.

${ }^{114}$ Ibid.
${ }^{115}$ Li Jingxuan 李靜軒, "Ganzi shibian zhi zeren wenti 甘孜事變之責任問題," Kangdao yuekan 2, no. 8 (1940): 11.

${ }^{116}$ Zhang Jian, "Ban yuan fan Zang yu " Ganzi shibian"," 119.
} 
them to non-Han forces that the Party did not fully control. Liu Wenhui may have erroneously believed that this was the central government's intention, although it seems unlikely that an experienced politician like Liu would make this kind of mistake. Even the 1940 sources connected to Liu Wenhui that do mention the idea of a conspiracy between the Panchen's office and the central government describe the idea as a frightening "rumour" (yaozhuo 謠豛), rather than something that was, in hindsight, a real possibility. ${ }^{117}$ The "rumour" that the Guomindang was planning to give control of northern Kham to the Panchen Lama's field office was almost certainly Liu Wenhui's post-hoc justification for what happened next, not an explanation for it.

In late 1939, an officer in the field office became engaged to marry Dechin Wangmo, a local chieftain and daughter of one of the most powerful Kanze families. Seeing the political implications of a union between the family and the Panchen's field office, Liu Wenhui opposed the marriage. Unable to influence either party, he had Dechin Wangmo arrested in late 1939. The field office responded by attacking and disarming the Twenty Fourth Army garrison in Kanze on 24 December 1939, following up with an attack on the Drango county garrison. Liu counter-attacked vigorously and quickly drove the field office and Dechin Wangmo out of Xikang.

In most accounts, Liu Wenhui is portrayed as being on the receiving end of a campaign against him. ${ }^{118}$ After the Field Office had disarmed Liu's garrison and taken over Kanze, Liu indeed faced a choice between losing some authority in northern Kham and defeating the Panchen's guard in a military confrontation. A valid question, however, is whether Liu deliberately courted the military confrontation. Was the arrest of Dechin Wangmo anything other than an attempt to provoke the Panchen's guard into starting a fight? It did nothing to break the relationship between her powerful family and the Panchen's field office, and it is difficult to see why Liu could have imagined that it would have. There may be no smoking-gun

\footnotetext{
${ }^{117}$ Li Jingxuan, "Ganzi shibian zhi zeren wenti," 11.

${ }^{118}$ Peng Wenbin, "Frontier Process, Provincial Politics and Movements for Khampa Autonomy During the Republican Period," 72.
} 
evidence in the form of an admission that he aimed to provoke an armed showdown with the field office. But if the "rumours" about the central government's intention of giving control of northern Kham to the Panchen's field office were mostly post-hoc legitimization, it is reasonable to attribute some of the blame for the conflict to Liu.

Perhaps the reason that Liu is rarely blamed for the conflict is that on the basis of the evidence presented in the usual accounts it is difficult to see why Liu would have courted a confrontation in Kanze when there were so many other parts of Xikang where his government had very limited authority. I argue that the Field Office's use of wula, which affected not just Kanze but trade in large parts of northern Kham, was an important factor in the build up of tension between the Xikang provincial government and the Panchen's guard. As any large political organization did, the Panchen's office levied a large amount of wula transporting its goods and personnel. ${ }^{119}$ The Kangding customs bureau and merchant community "complained vociferously” (ze you fan yan 嘖有煩言) about the behaviour of the office in this regard. ${ }^{120}$ They argued that seventy percent of the goods being transported from Sichuan to Kanze-in trains of hundreds of pack animals-consisted of commercial goods for sale rather than vital supplies. ${ }^{121}$ Whether or not this claim was true, if it was believed to be true, the merchants would have been angry for two reasons. Firstly, tax and transport costs made up a large portion of the price of goods imported to Kham from outside. So with tax-free wula transport, the field office would have been able to significantly undercut the merchants' prices. Secondly, because transport resources were severely limited, trains with hundreds of wula pack animals could very plausibly have driven up the prices that the merchants had to pay. Strong inflation began in 1939, so a rise in transport prices by itself does not necessarily indicate that the field office was responsible. Nevertheless, it would not have been unreasonable for merchants to believe that it was. The Kangding tax authorities predictably

\footnotetext{
${ }^{119}$ Li Jingxuan, "Ganzi shibian zhi zeren wenti," 11.

${ }^{120}$ Ibid.

${ }^{121}$ Ibid.
} 
sided with the merchants in complaining against the field office. The merchants, who were by and large tax payers, had a plausible case that they were losing business because of a field office that did not pay tax. Thus, from the perspective of both the merchants who sold Sichuanese goods in Kham and the Kangding customs authorities, the impact of the Panchen's field office was much more significant and detrimental than whatever impact it had on the local political situation in Kanze.

The field office was notionally an ally of the central government, so attempting to tax its supplies could have been diplomatically difficult for the provincial government. In any case, as we have seen, controlling the levying of wula was always difficult. Therefore, Liu Wenhui's government may have decided that the simplest course of action was to provoke a conflict that made it look as though the field office was the aggressor, and drive it out of Xikang.

\section{Conclusion}

The Xikang provincial government faced many challenges in Kham, but the “wula problem” was probably the toughest and it generated more discussion than any other issue. The problem had both environmental and institutional causes. In the age before engines that ran on hydrocarbon fuels that could be readily stored and transported, land transport relied on pack animals and fodder. In theory these things could have been imported to the highlands from outside. However, this would have been an immense logistical achievement and no governments managed to do this. Therefore all regimes relied on local animals and fodder for official transport. In a very sparsely populated region with tough terrain, increases in the size and centralization of the state and military presence greatly increased the burden on local livestock owners. Overburdened herders rebelled or moved out of reach of those who levied the corveé, causing very significant problems for the officials. Thus, political authority was reliant on a tax that was very difficult to increase. This meant that there was less space in Kham than in other parts of China for involutionary growth, that is, the simultaneous growth of 
multiple forms of authority. In Kham different authorities tended to compete with each other for the corvée that could be levied. This, I argue was one of the major causes of the Kanze conflict. The regional government also intervened to prevent its local agents from appropriating the value of this labour by converting it into cash payments. When Han military forces could not dominate rivals, there was a tendency for its relationships with them to be highly managed and structured around a minute division of the tax-base.

Twice the state attempted to break free from this situation by making alternative arrangements for its transport, which involved the creation of state livestock farms that would provide pack animals for official and military use. Neither attempt was successful, but these ventures did contribute to the development of the regional government's agricultural strategy. Indeed, the farms established in a vain but creative attempt to solve the wula problem remain a part of the Kham landscape to the present day. 


\section{Chapter Five: Conflict, Security and Ethnicity in Liangshan}

With the weakening of Han frontier authority around 1917, fighting broke out in many places throughout the highlands. Most accounts give the impression that violence in Liangshan was more intense than in most parts of Kham. In chapter one, we saw that Leibo lost fifty percent of its Han population between 1918 and 1920. Han authority was completely eliminated in Zhaojue. The large and profitable mines at Maha in Mianning were abandoned due to conflict. This violence was not well understood in the Republican period, and nor has it been satisfactorily explained since. At the time, it was simply referred to as the "Yi scourge” (Yi huan 夷患), which was used exclusively to talk about violence in Ningshu. No matter how violent some parts of Kham may have been at particular times, there was no idea of a "Kham barbarian scourge". The "Yi scourge" was part of the “Yi problem” ( $Y i$ wu wenti 夷務問題). The indigenous people of Ningshu were thus problematized in a way that the Kham indigenes never were. Although the latter were infrequently called yi 夷, “the $Y i$ wu wenti” always referred to Ningshu, and there was no equivalent "Kham people problem". Other terms were also localized to Ningshu as well. Writers fretted about "Yi areas” (Yi qu 夷區), or more emotively the "Yi lairs” (Yi chao 夷巢, literally “Yi nests”). There were plenty of entirely non-Han communities in Kham as well, yet there were no "Yi/Khampa areas" or "lairs" there. Another difference in the reporting of violence in the two places was that in Kham conflict was usually characterized as a form of (political) revolt (panluan 叛亂), incited by malevolent outside forces. A 1929 petition from Xikang settlers to the Nanjing government claimed:

The Tibetan soldiers [in the Lhasa army] repeatedly attempt to incite the obstinate elements of the eastern Kham population to rise up and expel the Han. [...] According to recent information in special dispatches from Chongqing, the British have also been inciting the Tibetan army to invade Xikang. ${ }^{1}$

\footnotetext{
${ }^{1} \mathrm{JKDZ}, 50$.
} 
The implication in this petition and in other similar reports is that violence in Kham was the result of meddling outsiders rather than the problematic nature of the Khampa, or other factors within Kham. Reports from Ningshu, by contrast, tended to relate violence to the basic nature of "the Yi" and their society.

This chapter works through the attempts of Republican period writers and later historians to explain the violence that occurred in Ningshu in the late 1910s and early 1920s. I argue against seeing this conflict as the result of intractable ethnic tension, or the opium trade, as other historians have done. I offer instead the interpretation that the Yunnanese occupation of Sichuan and the resulting budget cuts to Sichuanese military forces led to sudden unemployment for a large number of Yi mercenaries, who had served as security contractors for Chinese administrations for decades.

This chapter also examines the breakdown in the late Republican period of a form of tenancy agreement that Han migrants to the region in the eighteenth and nineteenth centuries had often made with Yi chiefs. The violence of the early Republican period, coupled with the end of this form of tenancy a couple of decades later, had the net effect of greatly reducing the degree of interaction between Yi and Han communities. The Republican period was an era of increasing ethnic segregation. Thus, like the previous chapter, this chapter also looks at how the development of local and regional Han authority was shaped by local problems and institutions.

\section{Backgrounds: Slavery and Historical Conflict}

For many observers in the Republican period, one of the primary causes of the "Yi problem" was relatively simple. It was the Yi themselves. They were a savage race of slave-owners, whose hunger for loot and more slaves drove them to attack Han communities. The 1941 Xichang Gazetteer stated: "The Yi of Xichang also delight in killing and plunder. They hate other races and their fortes are robbing, capturing, killing and burning the 
property of the Han people.” ${ }^{2}$ The term "Yi scourge” conveys the sense of a generalized calamity wrought by a purportedly barbaric people. It offered an interpretation of violent incidents that framed them as part of a general inclination for Yi to be violent against Han people; the term "Yi scourge" was never used when talking about violence within Yi communities.

Slavery certainly existed in pre-1950s Yi society, though as Ann Maxwell Hill argues, it would be better characterized as a "society with slaves" rather than a "slave society" as it has been labelled by post-1950s historiography. ${ }^{3}$ Slave owning was incidental rather than essential to $\mathrm{Yi}$ production and social structure. Moreover, not all Yi groups were equally engaged with the practice of capturing slaves from the fringes of Han settlements. A 1930s article on Leibo mentioned that "[the local Yi] usually aid in the defense of Han villages, and furthermore make great efforts in doing so." ${ }^{4}$ However, to Han who lived nearby to slave-raiding Yi groups, the mechanics of the $\mathrm{Yi}$ mode of production were probably much less important that the chilling prospect of being enslaved by the ethnic other. The probability of this occurring might have been quite low. Nevertheless, the psychological impact of the practice on Han communities and local governments ought to be taken into consideration as part of the background of the ethnic conflict in Ningshu.

This sense that the conflict was due to innate Yi savagery was at odds with the relatively common view that the Qing had been, in the words of the Sichuan-Xikang Survey Report, "an age of peace between the Han and Yi." 5 "The Yi always treated [government soldiers and messengers] with the greatest respect, and there were never any instances of messengers being ill

\footnotetext{
${ }^{2}$ Zheng Shaocheng 鄭少成 and Yang Zhaoji 楊肇基, "Xichang xian zhi 西昌縣志 [1941]," in Zhongguo Xizang ji Gan Qing Chuan Dian Zang qu fang zhi huibian 中國西藏及甘青 川滇藏區方志匯編, Vol. 40, ed. Zhang Yuxin 张羽新 (Beijing: Xueyuan chubanshe, 2003), 535.

${ }^{3}$ Ann Maxwell Hill, "Captives, Kin, and Slaves in Xiao Liangshan," The Journal of Asian Studies 60, no. 4 (2001): 1033.

${ }^{4}$ ZYDZ, "Leibo diaocha," 74.

${ }^{5}$ CKSB, 171. A similar narrative was given by ZYDZ, "Diaocha ziliao," Chuanbian jikan 1, no. 3 (1935): 165-68.
} 
treated or slighted.” ${ }^{6}$ In fact, the Qing had seen some bitter conflicts between imperial forces and some Yi groups, which the Survey Report hinted at but did not elaborate on. In 1868, Zhou Dawu 周達武 (18131895), the Provincial Military Commander (tidu 提督) of Guizhou had led 10,000 soldiers from that province to Yuesui, where he executed "corrupt and traitorous Han”, and then fought his way across Liangshan to Puxiong 普雄 in a tough campaign against rebellious Yi. ${ }^{7}$ The 1906 Yuesui Gazetteer rather coyly stated that when Zhou's forces dug themselves in at Puxiong to rebuild government offices "the Yi went into hiding and within three to four hundred li of the garrison there was no trace of any Yi." ${ }^{8}$ Liu Wenhui later commented that Zhou's forces killed "tens of thousands of Yi bandits", though he did not give a source for this figure. ${ }^{9}$ D'Ollone, by contrast, heard from unnamed sources that "In 1868 General Chao [Zhou] [...] suffered a complete defeat at [Yi] hands [...] and the Chinese were forced to recognize their independence.” 10 The details and outcome of the war clearly require further research. Nevertheless, it seems safe to assume that it involved a rather large loss of life for both sides. Even if we do not buy the "Yi delight in killing and plunder” interpretation of the early Republican violence, there was a real history of enmity between some Yi clans and Chinese authorities.

However, despite this background of tension, around 1917 something suddenly and dramatically ended the peace that had persisted with relatively few interruptions since 1869. As we saw in chapter one, in that year or one or two years later, Han populations that had been stable or rising suddenly

${ }^{6}$ CKSB, 171.

${ }^{7}$ Ma Zhongliang 馬忠良 and Sun Qiangzeng 孫鏘增, "Yuesui ting zhi 越崔廳志 [1906]," in Zhongguo Xizang ji Gan Qing Chuan Dian Zangqu fangzhi huibian 中國西藏及甘青 川滇藏區方志彙編, Vol. 39, ed. Zhang Yuxin 张羽新 (Beijing: Xueyuan chubanshe, 2003), 166 [original pagination: bianfang 邊防, 26a].

${ }^{8}$ Ibid.

${ }^{9}$ Liu Wenhui 劉文輝, "Ningshu Yi wu wenti zhi jiantao 甯屬夷務問題之檢討," Kangdao yuekan 2, no. 3 (1939): 2.

${ }^{10}$ Vicomte D'Ollone, In Forbidden China: the D'Ollone Mission, 1906-1909: China-TibetMongolia, trans. Bernard Miall (Boston: Small, Maynard and Company, 1912), 77. Goullart wrote more or less the same thing: Peter Goullart, Princes of the Black Bone, 120. 
began to fall, while mines and magistrates' offices were abandoned. In most places, this conflict began to die down in the late 1920s or early 1930s. Thus it was an historically specific phenomenon that occurred at a particular time, rather than a constant and inevitable feature of life on the Han-Yi frontier. Nineteenth century conflicts may have created an environment of mutual mistrust, but, like Yi slave-owning, they do not explain the rapid escalation of violence in the late 1910s

There are several types of explanation for that conflict within the existing literature. Firstly, there is an argument that violence intensified because of increased trade, particularly in opium and weapons. Secondly, throughout the twentieth century there has been a vein of interpretation suggesting that an upheaval within Yi society in the late nineteenth and early twentieth centuries was to blame. According to this view, tusi increasingly lost power to a more violent and unruly slave-owning aristocracy. Thirdly, many Republican era sources argued that there was a deterioration in either the strength or moral standards of Han governments in the region.

The following discussion analyses the evidence and arguments relating to opium first. I find that the trade probably was important, but that there are chronological and interpretive problems with many arguments. The view there was an upheaval within Yi society is intriguing, yet the link between that and the conflict between Han and Yi communities requires elaboration. On their own, the arguments concerning troop numbers and standards of governance are often somewhat unsatisfactory as well. However, seen within the broader context of the Yunnanese occupation of Sichuan, both are more plausible. Another consequence of that occupation, overlooked by both contemporary observers and later scholars, was the end an intricate system of security contracting relationships between local Han governments and Yi chiefs. 


\section{Trade, Opium and Guns}

Republican era writers and later historians have held the trade in opium and firearms responsible for the increase in violence in the twentieth century. Contemporary reports frequently accused corrupt military officers of selling firearms to Yi groups in exchange for opium. ${ }^{11}$ Such writers pointed out that this increased the capacity for recalcitrant $\mathrm{Yi}$ tribes and bandits to raid villages. Ann Maxwell Hill presents a variant argument, based predominantly on evidence from the Xiao Liangshan (Lesser Cold Mountains) in Yunnan, adjacent to Xikang's Da Liangshan (Greater Cold Mountains) region, though her conclusions relate more broadly to "old Liangshan society” and the Nuosu Yi in general. According to Hill, chiefs' demand for guns caused them to seek to increase opium production, for which they needed more labour and thus more captives. ${ }^{12}$

These arguments are interesting, but there are some problems with linking the increase in violence in the late Qing and Republican periods with the trade in opium and arms. The first is chronological. As we saw in chapter one, there were two periods in which a significant volume of opium was exported from Liangshan, both corresponding to relatively successful prohibition in the Sichuan basin. These periods were between 1906 and 1911, and from around 1936 onwards. However, as we have seen, the period in which violence was most intense in Liangshan was between 1917 and the early 1920s, a time when not much opium was exported from Liangshan.

There is also an interpretive problem. The key parties in the trade were in a state of near mutual dependence. The Yi had no other source of modern firearms and ammunition, while, during the periods of opium suppression, the opium dealers had few other suppliers. In some cases, the drug was a

\footnotetext{
${ }^{11}$ ZYDZ, "Leibo diaocha," 80; CKSB, 171; Xikang sheng canyihui: di er jie, di yi ci da hui hui bian 西康省參議會：第二屆第一次大會匯編 (Kangding: Kangyu gongsi, 1942) an wen 案文, 43a. This thesis has been picked up by later Chinese historians, see: Du Yuting 杜玉亭, "Yunnan Xiao Liangshan Yizu de nuli zhidu 云南小凉山彝族的奴隶制度," in Yunnan Xiao Liangshan Yizu shehui lishi diaocha 云南小凉山彝族社会历史调查, ed. Minzu wenti wuzhong conghsu Yunnan sheng bianji weiyuanhui 《民族问题五种丛书》 云南省编辑委员会 (Beijing: Minzu chubanshe, 2009), 22.

${ }^{12}$ Hill, "Captives, Kin, and Slaves in Xiao Liangshan," 1038.
} 
key source of local government revenue. This situation could also be conducive of good relations. In 1939, a report for Zhang Qun listed four reasons that Yi groups “submitted to” (toucheng 投誠) Han governments: if they were weak, had been defeated by the Han, lived near the Han, or had trading relations with the Han. ${ }^{13}$ In 1948 , Shi Wen wrote:

In recent years the Yi have gradually learnt from the Han the art of poppy cultivation [...] Who would have thought that mountainsides incapable of producing grains can grow opium so well! [...] Even in the most remote parts of the $\mathrm{Yi}$ regions, the $\mathrm{Yi}$ bandits cease robbing travelers during the poppy harvesting season and allow the Han to come and do business. ${ }^{14}$

It is not clear from the available evidence that the negative impacts of trade on ethnic relations outweighed the positive.

Furthermore, some accounts suggest that the opium exports of the late 1900s and late 1930s and 1940s occurred against a background of declining trade. Zeng Zhaolun wrote:

In the Qing period, many Han merchants went into Liangshan to trade cloth and salt [...] Such merchants traversed the whole region. [...] In the late Qing and early Republican periods, the Yi people became increasingly unruly. Han people who went into the mountains were often enslaved. Even merchants who had made great profits from trade no longer dared go into the hills. ${ }^{15}$

In chapter six we shall see that some merchants did in fact continue to go to Yi territory during the Republican period, and were generally safe if they made protection arrangements with Yi chiefs. But the "unruly Yi” was not the only reason for trade to decline. Before the late nineteenth century, an insect that produces wax used in the manufacture of candles was one of Liangshan's most significant exports (the insects breed better in Liangshan,

\footnotetext{
13 "Ningshu diaocha baogao huibian," junshi men 軍事門, 23.

${ }^{14}$ Shi Wen 石聞, "Xikang wei Zhongguo yin lai de san da wenti: yapian, yiwu yu Yingguo shili de ruqin 西康為中國引來的三大問題: 鴉片, 夷務與英國勢力的入侵," Shi yu wen 時與文 3, no. 22 (1948): 11.

${ }^{15}$ Zeng Zhaolun, Da Liang Shan Yi qu kao cha ji, 66-67.
} 
and were taken from there to Leshan where their wax was harvested). However, as Hosie wrote:

Since the introduction of kerosene oil into China and its almost universal use in the remotest provinces of the Empire, the demand for white wax has declined considerably [...] Not many years ago [...] ten thousand porters were required to carry the scales [containing insects] from the Chien-ch'ang [Jianchang] valley [...], and in 1884 we find that a thousand porters are able to transport the Chien-ch'ang supply. In many homesteads in Ssu-ch'uan [Sichuan], where candles were formerly the only lights, kerosene has been introduced. [...] The value, like the demand, has also declined. Not many years ago it was quoted at double the prices realized at present. ${ }^{16}$

If the two flowerings of opium export occurred against a background of declining trade in other commodities, then the view that the violence of the early Republican period was caused by the Yi clans' increased access to guns, which was supposedly thanks to an increase in trade, is problematic. It may have been that the volume of trade declined, but the value increased, but clearly the matter requires more research.

If the opium trade was important, it may well have been the end of the trade that mattered. In the 1906 to 1911 period, some Yi chiefs became accustomed to reaping substantial profit from selling opium or renting land to Han opium growers. ${ }^{17}$ When the export of opium from Liangshan ended, it is possible that some chiefs sought to replace those gains through robbery. Alternatively, as opium production increased in the Sichuan basin after 1911 and the price of poppies tumbled, Yi land would have had to produce much more to maintain the same income. This could have sparked the practice that Hill suggests: the raiding of Han villages for captives who could be put to work in poppy plantations. A third possibility is that because most Yi knew little about the situation in the Sichuan basin, it would have been hard for them to understand why the prices offered by Han merchants had declined so rapidly. Many descriptions of ethnic tension in Liangshan balance a stereotype of Yi savagery with one of Han proclivity to cheat the Yi in

\footnotetext{
${ }^{16}$ Alexander Hosie, Three Years in Western China: A Narrative of Three Journeys in Ssuchuan, Kuei-chow, and Yün-nan (London: George Philip \& Son, 1897), 200-01.

${ }^{17}$ Pollard, In Unknown China, 238.
} 
trade. ${ }^{18}$ Decreases in opium prices could have gelled with and supported this stereotype and touched off conflict in places that had profited from the 1906 to 1911 opium trade.

In sum, the post-1936 boom in opium exports from Liangshan resulted in Yi clans having more and better guns. However, these firearms were not used in the worst instances of ethnic conflict, because those incidences occurred between 1917 and 1920. The briefer 1906-1911 period of opium export from Liangshan must have given some Yi clans greater access to firearms, making the 1917 to 1920 conflicts more deadly than would otherwise have been the case. On the other hand, the end of the late Qing opium trade probably had a more significant detrimental effect on ethnic relations than the trade itself: More research in this area could prove worthwhile. The six year gap between the end of the trade and the onset of the most significant fighting also makes it difficult to accept that the trade was a core cause of that fighting, rather than just an intensifier of it.

Late Republican and post-1949 Chinese ethnography has frequently argued that in the late Qing and early Republican periods tusi authority declined in relation to a slave-owning aristocratic warrior caste. ${ }^{19}$ In Chinese, this group has usually been known as the Black Yi (Hei Yi 黑夷/ 彝), which derives from the meaning of the indigenous term "Nuosu”, or less often the Luo-Yi (猓夷/倮夷), which appears to come from a phonetic rendering of the same indigenous term. ${ }^{20}$ According to Stevan Harrell, "Nuosu" is the self-identification of almost all the Yi in Liangshan, among

\footnotetext{
${ }^{18}$ Shi Wen wrote: "The Yi people are often badly cheated by Han merchants” Shi Wen, "Xikang wei Zhongguo yin lai de san da wenti: yapian, yiwu yu Yingguo shili de ruqin," 11. See also Zeng Zhaolun, Da Liang Shan Yi qu kao cha ji, 37. Liu Wenhui wrote "The Yi people came to see me, and also said that in the past evil gentry (tu hao lie shen 土豪 劣紳) and the army and officials had conspired together to cheat, oppress and exploit them. I dispatched men to investigate and found that what they said was completely true." Liu Wenhui, "Ningshu Yi wu wenti zhi," 4.

19 "Ningshu diaocha baogao huibian," nongmu men 農牧門, 65-66; Yang Minghong, "Lun Qingdai Liangshan Yi qu de tusi zhidu yu gaituguiliu," 94.

${ }^{20}$ Stevan Harrell, "Ethnicity, Local Interests, and the State: Yi Communities in Southwest China," Comparative Studies in Society and History 32, no. 3 (1990): 525.
} 
whom the slave-owning aristocrats are properly called the nuohu. ${ }^{21}$ English languages scholarship usually identifies commoners and slaves as "Nuosu", but of the quho, mgajie and gaxy galo castes rather than nuohu castes. ${ }^{22}$ In Chinese, commoners and slaves tend to be labelled White Yi (Bai Yi 白夷/ 彝), or not "real Yi” at all. ${ }^{23}$ In many Chinese accounts, the increasing dominance of the slave-raiding Black Yi/ "real Yi" over the other strata of non-Han Liangshan society caused the conflict of the early twentieth century. "When the Black Yi replaced the nzymo (Ch. zimo兹莫) [a royal elite] to become the paramount leaders [of Liangshan indigenous society], the slave system entered its historical peak, and raiding for captives became more intense." ${ }^{24}$ Han Chinese were not the only victims of the rising and aggressive Black Yi:

In the Daoguang reign (1821-1850) there were no Luo-Yi in Yanyuan and Yanbian. However, the tusi became wary of Han tenants and instead began to recruit Luo-Yi to cultivate their land. In the end, the Black Yi became the tail that wagged the tusi dog (wei da bu diao 尾大 不掉). The native offices were burned and the Xifan 西番 and Moxie 麼些 peoples were driven away. ${ }^{25}$

In many respects, this is the 'savagery-and-slavery' interpretation of the "Yi scourge”, made more logical by its capacity to explain why, at a specific historical moment, relations between Han and certain non-Han communities got much worse. The puzzle of why tusi power declined relative to the Black Yi / Luo-Yi remains, and some sources relate it to late imperial gaitu-

\footnotetext{
${ }^{21}$ Harrell, "Introduction," in Perspectives on the Yi of Southwest China, ed. Stevan Harrell (Berkeley: University of California Press, 2001), 9, 11.

22 Ibid.; Lu Hui, "Preferential Bilateral-Cross-Cousin Marriage among the Nuosu in Liangshan," in Perspectives on the Yi of Southwest China, ed. Stevan Harrell (Berkeley: University of California Press, 2001), 68.

${ }^{23}$ Zhongguo kexueyuan minzu yanjiu suo 中国科学院民族研究所 and Sichuan shaoshu minzu shehui lishi diaocha zu 四川少数民族社会历史调查组, eds., Liangshan Xichang Yizu diqu tusi lishi ji tusi tongzhi qu shehui gaikuang (ziliao huiji) 凉山西昌彝族地区土 司历史及土司统治区社会概况（资料汇辑）(1963), 51.

${ }^{24}$ Yang Minghong, "Lun Qingdai Liangshan Yi qu de tusi zhidu yu gaituguiliu," 94.

25 "Ningshu diaocha baogao huibian," zhengsu men 政俗門, 15.
} 
guiliu or other Han military campaigning, though these things did not occur everywhere in Liangshan. ${ }^{26}$

This argument is intriguing and certainly worthy of further research, though there are some interpretive problems. The above discussion should be adequate to demonstrate that terms such as "Black Yi” are unstable and ill-defined: single terms are used differently by different observers. In the Liangshan context, "tusi” is particularly problematic. In imperial political theory, "tusi" households had, at some point in the Yuan-Ming-Qing era been granted official recognition from a Mongol, Han or Manchu emperor. In this sense, not all indigenous leaders were tusi. With such a definition the argument regarding the rise of the non-tusi aristocracy is at least a logical proposition. Yet in the early twentieth century, the term "tusi” was also used more broadly to signify any non-Han leader who served as a benign mediator between the Chinese bureaucracy and the world of the barbarian. Even the adopted Yi son of the magistrate of Hanyuan was called a tusi by local Chinese. ${ }^{27}$ In this usage, the term was similar to the labels "cooked" (shu 熟) and “raw” (sheng 生) for “civilized” and “uncivilized” barbarians respectively. These names mostly described the referents' political behaviour and loyalties, rather than their cultural orientation and, in the case of "tusi", their actual position in non-Han society. This reduces the argument related in the previous paragraph to a claim that a group of illdefined non-friendly indigenous leaders replaced a group of equally illdefined friendly indigenous leaders. There is no real evidence that the people in the two sets were always different individuals. According to a lot of scholarship, the tusi were drawn from nzymo elite; if the nzymo were also Black Yi, as some historians have it, one wonders what separated the tusi from the "Black Yi slave-owners" who have been cast as the bugbears of peace-loving communities in Liangshan. ${ }^{28}$ It may be that a careful

\footnotetext{
${ }^{26}$ Wu Wenhui 吴文暉 and Zhu Jianhua 朱鑒華, "Xikang tudi wenti 西康土地問題," Bianzheng gonglun 邊政公論 3, no. 6 (1944): 11.

${ }^{27}$ Zeng Zhaolun, Da Liang Shan Yi qu kao cha ji, 53; Goullart, Princes of the Black Bone, 115.

${ }^{28}$ Hui defines the nzymo as Black Yi, for example Hui, "Preferential Bilateral-Cross-Cousin Marriage among the Nuosu in Liangshan," 68.
} 
examination of Yi language sources will reveal a relatively clear distinction. But it is also worth considering what happens when we stop attempting to ascribe blame to a vague cultural group, and instead analyze the specifics of the local political contexts in which the violence of 1917 erupted. The following sections of this chapter do this by sketching the impact of the Yunnanese occupation of Sichuan on Liangshan, and in particular the way that it affected an intricate security arrangement that had existed in many parts of Liangshan for at least half a century.

The Yunnanese Occupation and the Qing Security Arrangements

As we saw in chapter one, the Yunnanese occupation of Sichuan led to drastic budget cuts across Sichuanese military units, including the Frontier Defence Force. There were three main impacts on local politics on the YiHan frontier. Firstly, the cuts suffered by the Sichuanese military probably resulted in the disbanding of garrisons in some locations. Although Republican sources were inexplicably shy about blaming the Yunnanese, they rarely failed to point out that the conflict in Sichuan weakened the frontier garrisons. The 1946 New Gazetteer for the Sichuan Frontier reported:

In the past, border defences were sturdy. The garrisons put fear into the hearts of the Yi. They hibernated (zhe蟄) in their mountains. In the Republican era, due to the chaos in Sichuan the border defenses have slackened and the Yi have run rampant. ${ }^{29}$

This referred specifically to Leibo, Mabian and Pingshan, and echoed what investigations published in Sichuan Frontier Quarterly had written about the same places in the $1935 .{ }^{30}$ However, it is uncertain as to whether there was a net loss of soldiers in any region. During this time Sichuan was the

\footnotetext{
${ }^{29}$ Zheng Lijian 鄭勵儉, "Chuanbian xin di zhi 川邊新地志 [1946]," in Zhongguo Xizang ji Gan Qing Chuan Dian Zang qu fang zhi huibian 中國西藏及甘青川滇藏區方志彙編, Vol 44, ed. Zhang Yuxin 张羽新 (Beijing: Xueyuan chubanshe, 2003), 429.

${ }^{30}$ ZYDZ, "Diaocha ziliao," Chuanbian jikan 1, no. 3 (1935) 166.
} 
reluctant host to three million personnel from the Yunnan army. ${ }^{31}$ The compilers of the 1941 Xichang Gazetteer noted that in 1920 the Yunnan army deployed troops throughout Ningshu, though they had no information on the numbers of soldiers in such garrisons. ${ }^{32}$

Secondly, the Yunnanese and Sichuanese military units competed with each other for income, and there is evidence that in many places both began taxing Yi communities. The Yunnanese garrison commander stationed in Leibo, is reported to have "extorted money from the people as he wished, which aroused the hostility of the Yi people, causing them to rise up and fight back.”33 An article about Mabian describes how one garrison began "luring the wealthy Black Yi into captivity and demanding ransoms for their release, a practice called 'catching fat pigs' by the bandits in the interior."34 As we shall see in chapter seven, blaming unethical governance for the frontier's problems was one of the key tropes in Han discourse about the region, and perhaps had more to do with the culture of Han politics than anything else. However, the struggle between the Yunnanese and Sichuanese militaries, and the desperate search of both for revenue, provides a plausible context for the argument that standards of government declined and that relations with Yi communities were a casualty of that decline.

Thirdly, the budget cuts sustained by the Sichuanese garrisons led to the sudden unemployment of significant numbers of Yi mercenaries. In the late Qing a complicated system designed to ensure stability in the ethnically mixed regions of Liangshan developed. According to the Yuesui Gazeteer and D'Ollone, the system was created after the 1868 war, though an article in Sichuan Frontier Quarterly stated that, in Mabian at least, it was established as early as the Jiaqing reign, so possibly Zhou Dawu merely expanded an already existing practice. ${ }^{35}$ Under this system, the government

\footnotetext{
${ }^{31}$ Yi Bin, "Shilun min chu Sichuan difang zhuyi de sheng ji guanxi," 87.

32 Zheng Shaocheng and Yang Zhaoji, "Xichang xian zhi," 420.

33 ZYDZ, "Leibo diaocha," 83.

${ }^{34}$ ZYDZ, "Mabian Yi ren diaocha 馬邊夷人調查," Chuanbian jikan 1, no. 3 (1935): 137.

${ }^{35}$ Vicomte D'Ollone, In Forbidden China, 77; Ma Zhongliang and Sun Qiangzeng, "Yuesui ting zhi," 167-69 [original pagination: bianfang 邊防, 26a]; ZYDZ, "Mabian Yi ren diaocha," 136.
} 
paid Yi leaders to be responsible for the security of a designated area. ${ }^{36}$ Most sources give the impression that such chiefs were primarily responsible for preventing Yi crimes against Han. It is unclear who was responsible for Han crime against $\mathrm{Yi}$. Yi leaders in this role who failed to deal with breaches of the peace in their beat would be held personally responsible and suffer the loss of their wages.

This practice often merged with a system whereby selected Yi leaders had to reside in Yi ka (夷卡), or "Yi guardhouses”. Accounts of the Yi ka give divergent and ambiguous impressions of what this actually meant. Fergusson gave the following description of the situation in Yuesui:

In a kind of prison or hostel in connection with the Yamen [government office] are to be seen a number of hostages who may be seen also in our photographs. These hostages come from various parts along the border, and are representative leaders or chiefs, who take turns of imprisonment to go pledge for the good conduct of their tribes. These chiefs are paid a nominal sum by the Chinese Government for thus serving a period in durance, and after serving a term of three months they are allowed to be relieved by other representative men of their tribes. ${ }^{37}$

Fergusson called the Yi "hostages", yet he was clearly not quite sure about their status, being uncertain as to whether to call the $Y i k a$ a "prison" or a “hostel”. This was hardly Fergusson's fault as other accounts are often fairly unclear or contradictory too. Some accounts refer to the Yi leaders in the $Y i$ $k a$ as “doing service” (dang chai 當差). ${ }^{38}$ A late Republican source described the function of the $Y i k a$ thus:

The purpose of the $Y i k a$ in the Qing dynasty was primarily to detain (juliu 拘留) the hostages (renzhi 人質) sent by the Yi tribes in order to prevent them from rebelling. ${ }^{39}$

\footnotetext{
${ }^{36}$ Ma Zhongliang and Sun Qiangzeng, "Yuesui tingzhi," 167-69 [original pagination: bianfang 邊防, 26a-32b]. See also ZYDZ, "Mabian Yi ren diaocha," 136.

${ }^{37}$ W.N. Fergusson, Adventure, Sport and Travel on the Tibetan Steppes (London: Constable and Company, Ltd., 1911), 289.

${ }^{38}$ ZYDZ, "Mabian Yi ren diaocha," 136.

${ }^{39}$ Zeng Zhaolun, Da Liang Shan Yi qu kao cha ji, 36.
} 
Writing about his visit in the late Republican period, Goullart called the yi ka “yamen” (衙門); 'government offices' rather than 'prisons'. ${ }^{40}$ No source I have encountered indicates whether the "hostages" were ever subject to other forms of punishment in addition to the loss of their wage if they failed to ensure peace in their area of responsibility.

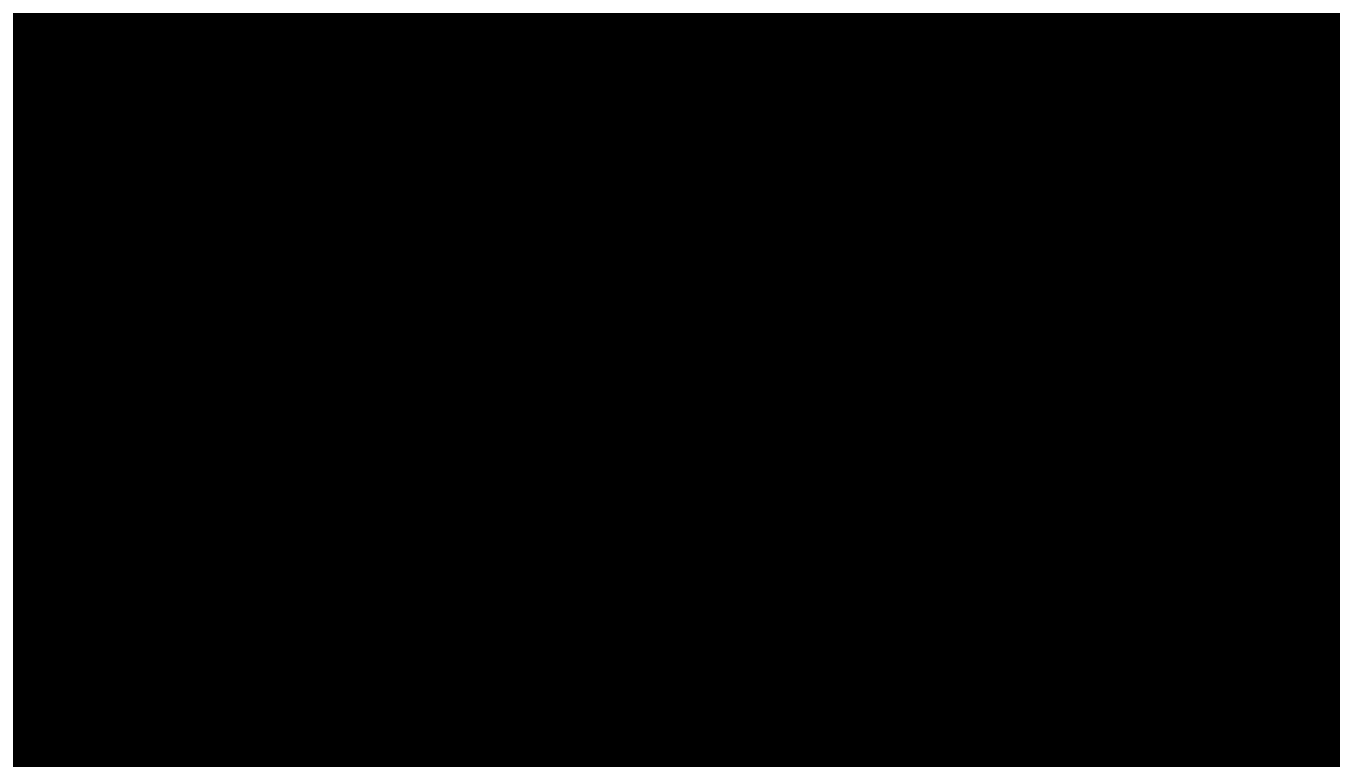

Yi chiefs in the Yuesui Yi ka, from Fergusson. ${ }^{41}$

The Republican period accounts that fail to mention that the Yi leaders in question were paid for their "service" as "hostages" are also clearly missing something. Even Fergusson's account is potentially misleading because such payments could be much more substantial than "nominal". According to one description, there was a system of ranks for Yi with whom the government had such relationships. ${ }^{42}$ All ranked Yi received a wage (Yi xiang 夷館), though only “aristocrats with authority” were required to take turns at residing in the Yi ka. In Mabian, the Yi yue 夷約, the lowest paid, got eight taels of silver per year, the "Yi soldiers” (Yi bing 夷兵) eight to

\footnotetext{
${ }^{40}$ Goullart, Princes of the Black Bone, 119.

${ }^{41}$ Fergusson, Adventure, Sport and Travel, 301.

42 ZYDZ, "Mabian Yi ren diaocha," 136.
} 
twelve taels, while the highest paid, the "thousand household supervisors" (qianhu 千戶) got between 24 and 34 taels. $^{43}$ In the late Qing, soldiers in the regular Green Standard army received one tael per month, so the better paid "Yi soldiers" had pay-parity with soldiers in the regular armed forces. ${ }^{44}$ The Yi bing, moreover, were irregular fighters, who were not required to live in a barracks. According to Sichuan Frontier Quarterly, by the end of the Qing, Mabian County's annual wage bill for the Yi amounted to 7,256 taels, which was paid by the Sichuan government. ${ }^{45}$ A more detailed late Qing source stated that with some contributions from county governments, the Sichuan provincial government paid out 22,115 taels annually to cover $Y i$ xiang for 598 Yi fighters in Ebian, Mabian, Leibo and Pingshan, as well as the costs of associated with the Yi ka in those counties. ${ }^{46}$ Referring generally to the other side of the Liangshan, Vicomte D'Ollone wrote that at the time of his 1906 visit, the "frontier clans" received an average of between 75 and 150 taels annually for their services, though the size of these "clans" is unclear. $^{47}$

If the $\mathrm{Yi}$ in the $\mathrm{Yi} k \mathrm{k}$ were not necessarily the hostages of an oppressive regime, as some writers in the Republican period portrayed them, nor were they bold natives who turned the tables on the Chinese state and extorted tribute money from it, which is the impression D’Ollone gives. ${ }^{48}$ The majority of tusi in the Qing Empire were not paid. ${ }^{49}$ But the Yi militias of Liangshan, like certain native officials and their fighters in Yunnan who

${ }^{43}$ Ibid.

${ }^{44}$ Li Zhiming 李志茗, "Yong ying zhidu: Qing dai jun zhi de zhong jian xingtai 勇营制度

: 清代军制的中间形态," Shi lin 史林, no. 4 (2006): 32.

${ }^{45}$ ZYDZ, "Mabian Yi ren diaocha," 136.

${ }^{46}$ Du Mingyi 杜明燡, "E Ma Lei Ping bianwu cha biao ce 峨馬雷屏邊務查表冊," in Zhongguo shaoshu minzu guji jicheng. Han yihou Xinan ge minzu. 中國少數民族古籍集 成。漢以後西南各民族, Vol. 94 (Chengdu: Sichuan minzu chubanshe, 2002), 418.

${ }^{47}$ D'Ollone, In Forbidden China, 37.

${ }^{48}$ Ibid.

${ }^{49}$ For example, the tusi that are the subject of Jennifer Took's monograph were not paid: Jennifer Took, A Native Chieftaincy in Southwest China: Franchising a Tai Chieftaincy under the Tusi System of Late Imperial China (Leiden: Brill, 2005), 191. 
became “essential mercenary forces for the Qing” at the same time, did more for the Qing than the unpaid indigenous leaders of other parts of the empire. ${ }^{50}$ Passing through one Yi settlement, H. R. Davies noted that "The son of the head-man was at the time of our visit away with a good many of the young men of the place, helping the Chinese in an expedition against some of the independent Lolos [Yi]."51 Qing generals also recruited the Yi mercenaries from Ningyuan Prefecture for their campaign against the Panthay Rebellion (1856-1873) in Yunnan: a rare instance of irregular fighters who were not Han, Manchu or Mongol being deployed across a provincial boundary. ${ }^{52}$

In some places, problems with this system appear to have developed before the end of the Qing. According to Samuel Pollard, even in the Panthay rebellion, there had been conflict between the Yi mercenaries and their employers. Pollard heard that the Yi fighters in Yunnan had had their pay withheld. "The Nosu [Yi] soldiers, of course resented this and determined to get equal with those who were squeezing them.”53 There are reports indicating that by the late nineteenth century demographic pressures were also putting the system under strain. According to the Sichuan Frontier Quarterly article on Mabian, the Yi population increased during this time. ${ }^{54}$ This meant that over time the wages provided by the government were shared between more people, with the obvious result that individuals received less. In addition, some individuals whose families had been accustomed to receiving the payments were shut out of the system. According to the report, such individuals began "deliberately making trouble” (gu yi daoluan 故意搗亂). ${ }^{55}$

\footnotetext{
${ }^{50}$ Giersch, Asian Borderlands, 115.

${ }^{51}$ H. R. Davies, Yün-nan, the link between India and the Yangtze (Taipei: Ch'eng Wen Publishing Company, 1970 [1909]), 213.

${ }^{52}$ Pollard, In Unknown China, 178.

${ }^{53}$ Ibid.

${ }^{54}$ ZYDZ, "Mabian Yi ren diaocha," 136.

${ }^{55}$ Ibid.
} 
However, the major problem occurred in the early Republican period, when “the province’s finances dried up” (sheng kuan duan jue 省款糹絕), and there was no longer any money to pay the yi xiang. ${ }^{56}$ One overview of the Mabian-Pingshan-Leibo region gave a broad-brush history of the conflicts, stating that:

When the old regime disintegrated, the authority of the government was ruined and the Yi stipends and rations were also stopped. [...] Whereupon the Yi seized the opportunity to come out of their nests (chao 巢), causing mayhem on an immense scale; trespassing burning, killing and looting. ${ }^{57}$

The reports in Sichuan Frontier Quarterly did not relate the "drying up” of the funds that were previously used to pay the Yi wages specifically to the Yunnan occupation. Nor do they state directly that the $\mathrm{Yi}$ of the "Yi Scourge” were disgruntled former employees of the Chinese state. However, given the information that the reports do provide, and the occurrence of the "Yi Scourge" at exactly the same time as the Yunnan army cut the budgets of Sichuanese military units, I believe we can reasonably infer both of these things.

Firstly, it is clear that local garrisons were still able to employ the $\mathrm{Yi}$ in the years immediately after the revolution; their funding did not end with the Qing dynasty. For example, in June 1917 a local garrison commander was able to "bribe (hui 賄) the Yi of the Wuqi 吳奇 clan to enter the city and guard the county offices.” ${ }^{58}$ He also recruited various other Yi clans from Liangshan "to occupy the town and surrounding countryside." 59

The Wuqi Yi were no strangers to this role. In the west of the county, more than one hundred Han households had lived under Wuqi protection (baohu保護) before the revolution. ${ }^{60}$ The article does not state that the Wuqi

\footnotetext{
${ }^{56}$ Ibid.: 137.

${ }^{57}$ ZYDZ, "Diaocha ziliao," Chuanbian jikan 1, no. 3 (1935): 166.

${ }^{58}$ ZYDZ, "Leibo diaocha," 80.

59 Ibid.: 81.

${ }^{60}$ Ibid.: 74.
} 
received payments for the protection they granted these communities before the revolution. But Yi who were paid under the system described above were usually referred to euphemistically as the providers or guarantors of "protection (baohu)". Combined with the evidence that demonstrates this system was widespread throughout Liangshan in the late Qing, it can be safely assumed that the Wuqi of Leibo did receive remuneration for their services before 1911, which clearly continued after the revolution until 1917.

In April 1918, however, the Wuqi were among those who "came out of their lairs" to pillage the Han communities. ${ }^{61}$ Again, the article does not state directly that they did this because their wages were no longer being paid. But given what we know about the broader context, this is the simplest and most likely explanation for the Wuqi's shift from protector to menace. After all, the military unit that became a bandit gang after having its wages cut or withheld is a familiar figure from Republican period history. ${ }^{62}$ Of bandits in general in the Sichuan frontier, Sichuan-Xikang Survey Report wrote "bandits and soldiers are one and the same thing.",63

In many places, the Qing system, or a modified version of it, was revived during the late 1920s or early 1930s. Mabian, for example, established two defense institutions that involved the Yi. One was an office called the Yi Affairs Bureau (Yi wu chu 夷務處), which made monthly payments, which were still called Yi xiang after the Qing nomenclature, to Yi groups who had 'submitted' in return for their assistance with problems involving other $\mathrm{Yi}^{64}$ In most respects this was a straightforward return to the Qing status quo. The county government does not appear to have required representative leaders to reside in $\mathrm{Yi} k \mathrm{ka}$, but this system resurfaced in other places in Liangshan. Chang Longqing commented that the safety of his expedition had been guaranteed by a nephew of a chieftain serving as a

\footnotetext{
${ }^{61}$ Ibid.: 82.

62 See Phil Billingsley, Bandits in Republican China (Stanford: Stanford University Press, 1988), 79-80.

${ }^{63}$ CKSB, 141.

${ }^{64}$ ZYDZ, "Mabian Yi ren diaocha," 138.
} 
“hostage” (renzhi 人質) in Xichang. ${ }^{65}$ In addition, Mabian and some other counties established small brigades of regular Yi soldiers, which were integrated in some way with the local Han military forces. ${ }^{66}$ In Xichang, the situation was similar. Deng Xiuting, the local military commander who was widely credited with improving the security situation in that county, established an Yi regiment which made up one third of the total forces under his control. ${ }^{67}$ Reports considered members of this regiment to be regular soldiers, but as one researcher pointed out, because they usually wore their own clothes instead of uniforms outsiders were unable to identify them as such. ${ }^{68}$ Measures such as this did not result in a complete cessation of conflict, but combined with the increase in regional government military strength, they did lead to a significant decline in violence.

Yang Gengguang's report of the Bathang Cultivation Society's (see chapter one) relocation to Yi territory in Leshan in the last years of the Qing explicitly attributes peaceful relations between the Yi and Han communities then and in the Republican period to the maintenance of security contracting agreements. Before the revolution, the Leshan government made substantial payments to local Yi. ${ }^{69}$ Yang notes that "because of the bao shan 包山 agreements, there was no Yi scourge to speak of". ${ }^{70}$ The term "Bao shan" could mean a couple of different things but in this report, it almost certainly referred to some form of security contract, the "bao" meaning "guarantee" as in baopei 包賠; ‘to guarantee to pay compensation'. Hence bao shan should be something like "guaranteeing the mountains". Bao shan is also used this way by Zeng Zhuyun:

\footnotetext{
${ }^{65}$ Chang Longqing 常隆慶, Lei Ma E Ping diaocha ji 雷馬峨屏調查記 (Chongqing: Zhongguo xi bu ke xue yuan, 1935), 15.

${ }^{66}$ ZYDZ, "Mabian Yi ren diaocha," 137.

${ }^{67}$ Zeng Zhaolun, Da Liang Shan Yi qu kao cha ji, 42.

68 "Ningshu diaocha baogao huibian," zhengsu men 政俗門, 27.

${ }^{69}$ Yang’s text has “500 jin 金 [gold]”; jin probably means ‘taels' (liang 兩). Yang Gengguang, "Sichuan Le-Ping kenwu," 9.

${ }^{70}$ Ibid.
} 
In the Qing dynasty, the government adopted a loose rein policy for ruling the Yi. It established Yi officials (Yi guan 夷官), and gave them the prerogative (quanli 權利) of guaranteeing security in the mountains and protecting the roads (yu yi baoshan baolu de quanli 予以包山保路 的權利). ${ }^{71}$

Note that the Chinese word quanli 權利 is normally translated as 'rights'. In this context, 'prerogative' is more accurate because the 'right' in question is to be the protectors of travellers in the mountains. That this is framed as a 'right' rather than a duty (yiwu 義務) indicates that the Yi received some benefit from doing so.

In 1932 Yang's society re-made a bao shan contract with a chief called Hongche’er 紅扯兒 in which it agreed to pay 250 taels per year in Yi xiang to be divided among the chiefs of local clans. ${ }^{72}$ For unstated reasons one particular Yi chief was unhappy with the situation and took some of the society’s farmers (kenhu 墾戶) hostage. The society complained to Hongche’er and received support from a chief called Sansan'er 三三兒 in its attempt to rescue the hostages. After a battle, there were negotiations which resulted in Hongche'er securing the release of the hostages and the society receiving 500 yuan in compensation. The next year there was a formal signing of the bao shan agreement, attended by the society, eight members of the local Han gentry, representatives of the local Han government, and the Yi chiefs Hongche'er and Sansan'er with 80 of their followers. Yang reported that "in 1935, after the signing of the bao shan agreement, relations between the $\mathrm{Yi}$ and Han were peaceful and uneventful." 73

The breakdown of the security contracting relationships was not the only cause of violence, and their revival was probably not the only cause of the improving situation in the 1930s. However, the evidence indicates that these relationships were an important factor in both of these phenomena. Why would many reports be coy about stating this directly? One reason is that

\footnotetext{
${ }^{71}$ Zeng Zhaolun, Da Liang Shan Yi qu kao cha ji, 39.

72 Yang Gengguang, "Sichuan Le-Ping kenwu gongshe," 30.

${ }^{73}$ Ibid.: 32.
} 
this explanation did not gel very well with the interpretation that the conflict was caused by fundamental Yi savagery and hunger for slaves. As we saw above, this was one of the key Republican period framings for the violence. According to this interpretation, Yi who helped the government were seen as more civilized/Chinese than the wild "uncooked" Yi, who took the blame for the conflict. ${ }^{74} \mathrm{~A}$ Yi group's degree of distance from Chinese culture and administration was related to their propensity to attack Han settlements. The view that violence was caused by Yi otherness was thoroughly compatible with the core nation-building concerns of many twentieth century leaders and intellectuals, who were already pre-occupied with the task of building cultural and administrative unity. The revelation that the "Yi scourge" was wrought in part by the Yi who had worked most closely with the Qing would have demonstrated that closeness did not lead inexorably toward greater stability.

The rebuilding of the security contracting relationships helped to end the violence. However, this was not something that satisfied nation-building prescriptions for the region either. To most Republican period commentators, paying salaries to Yi who did not wear government issued uniforms and live in barracks was a form of jimi 羈縻; 'loose rein' governance. ${ }^{75}$ For them, jimi was a pejorative term that meant empowering local elites but allowing them to act autonomously with little or no supervision. Qing accounts, such as that given in Yuesui Gazetteer, never described the security contracting system as jimi. From the Qing perspective such a characterization would not have made sense. After all, the system was a lot less 'loose rein' than having no relationship at all with the Yi elites, which was the likely alternative. By the 1930s the goal of assimilating the whole region into the Republic's regular administrative system was never seriously questioned. The use of the term 'jimi' to describe the security contracting system reflected the transformed expectations of the Republican period.

\footnotetext{
${ }^{74}$ ZYDZ, "Leibo diaocha," 74; Ling Guangdian 嶺光電, "Wo dui Leibo Yi ren de guangan 我對雷波夷人的觀感," Kang Zang yanjiu yuekan 康藏研究月刊, no. 11 (1946): 28-32.

${ }^{75}$ See ZYDZ, "Mabian Yi ren diaocha," 137.
} 


\section{Land Tenure and the Hongzhao}

In addition to the security contracting relationships, a second local institution also broke down in the Republican period. In this case, the breakup may have been less violent. It resulted, all the same, in a greater degree of separation between $\mathrm{Yi}$ and Han communities. This institution was a particular form of tenancy agreement between Han settlers and Yi chiefs.

The Qing dynasty saw a massive influx of Han migrants into Ningyuan. ${ }^{76}$ Many migrants established farms in the region, for which they acquired land from the Yi. One of the means by which this occurred was the creation of land use agreements that the Chinese sources call hongzhao 紅照 ("red tickets"). This was a kind of inheritable tenancy, although Republican period observers did not refer to them with the same terms as those used for the permanent tenancy in Interior China, or state that the two customs were the same. All the sources I have encountered are clear that they are tenancy agreements, not purchase agreements. ${ }^{77}$ According to Wu Migeng, their use was not restricted to deals between Han and Yi. Wu states that most land in the Yi regions was held by the "Black Yi" aristocracy, but some powerful "tusi" also had substantial land holdings that were documented with hongzhao, understood in broadly the same terms as given in other descriptions. $^{78}$

Due to apparent tusi need for cash in the late Qing, it became common for them to jia ya 加押, a term also found in the Chengdu plain, which literally meant "increase the deposit/tenancy fee" (it is not always clear whether $y a$ 押 should be thought of as a refundable deposit or a tenancy

\footnotetext{
${ }^{76}$ In 1711 Ningyuan Prefecture's total population was recorded at 12,500 people. In 1820 it was recorded as 1,266,273. Liu Zhenggang 刘正刚 and Tang Weihua 唐伟华, "Qing dai yimin yu Han Yi jiaoliu tantao 清代移民与汉彝交流探讨," Guizhou minzu yanjiu 贵州 民族研究 22, no. 90 (2002): 147. This migration was part of the broader mass movement of Han Chinese to the southwest. On migration to Yunnan, see Giersch, Asian Borderlands.

${ }^{77}$ See for example Fu Zhenyuan 傅真元, "Liang yan hong zhao di zhi neirong ji qi jiejue zhi tujing 两盐红照地之内容及其解决之途径," Kangdao yuekan 4, no. 8,9 (合刊) (1941); Wang Zhengguan 汪正琯, "Yanyuan jixing 鹽源紀行," Kangdao yuekan 5, no. 6 (1943).

${ }^{78}$ Wu Migeng, "Jiejue Xikang Kang Ning liang shu diquan wenti," 38.
} 
fee) ${ }^{79}$ In reality jia ya was a way of loaning money from tenants, as tenants got a rent reduction in return. ${ }^{80}$ In this respect, the practice was the same on the Chengdu plain and in Ningshu. It is uncertain why tusi needed to raise more cash; Fu Zhenyuan interprets it as a result of their "pride and extravagance”. ${ }^{81}$

In Republican period Ningshu it appears that there were relatively frequent confrontations between Han holders of hongzhao tenancy and the tusi who nominally owned the land but had perhaps not used it for generations and often collected little rent from it because they or their forebears had resorted to jia ya. According to Wang Zhengguan, in Yanyuan and Yanbian the tusi became rich due to cultivation of opium, and "without regard to inflation, demanded the return of their land according to the prices of the past, and the Han farmers, who had worked hard for several generations, were suddenly left with nothing." ${ }^{82}$ While these writers blame the tusi, the Xikang Provincial Assembly canyihui 參議會) also pointed its fingers at "capital from outside the province" in the hands of unnamed “companies, groups and private individuals." ${ }^{83}$ Working under the pretext of the "admirable cause of cultivation" such outsiders were said to use large amounts of money to "snatch (juequ 筫取) fields that had already been cultivated by Han farmers." 84 “Attracted by the large sums offered to them, the tusi seized the hongzhao without consulting the tenants, and transferred the tenancy to others or even sold the land.”,85

\footnotetext{
${ }^{79}$ Fu Zhenyuan 傅真元, "Liang yan hong zhao di zhi neirong ji qi jiejue zhi tujing 两盐红 照地之内容及其解决之途径," 44. On the use of the term in the Chengdu plain, see Li Deying 李德英, "Minguo shiqi Chengdu pingyuan de yazu yu yakou 民国时期成都平原 的押租与押扣," Jindai shi yanjiu 近代史研究, no. 1 (2007).

${ }^{80}$ Fu Zhenyuan, "Liang yan hong zhao di zhi neirong ji qi jiejue zhi tujing," 43.

${ }^{81}$ Ibid.: 44.

${ }^{82}$ Wang Zhengguan, "Yanyuan jixing," 61-71.

${ }^{83}$ Xikang sheng canyihui 西康省參議會, "Linshi canyihui, di yi ci hui huibian 臨時參議會 第一次會匯編," 1940, (SCDAG, QZH:204, AJH:14), section 8, p.12a.

${ }^{84}$ Ibid.

${ }^{85}$ Ibid.
} 
Whether or not they were aware of it, the tusi might often have had a good case under Guomindang law. Lawmakers of the late Qing and Republican period sought to restrict the rights of permanent tenants, or 'topsoil owners' in order to move toward Western notions of unitary ownership. ${ }^{86}$ The 1929 Guomindang code included a provision that allowed landlords to end permanent tenancies if they wished to farm the land themselves. ${ }^{87}$ However, this caused controversy throughout China, and courts often ruled in favour of tenants despite the provisions in the new legal codes.

There was a certain amount of debate as to how the provincial government ought to deal with Ningshu's hongzhao. Some evidence suggests that there was a considerable amount of lobbying from the Han holders of hongzhao for the government to recognize the documents as deeds of full ownership (suoyou quan 所有權). ${ }^{88}$ Not all Han commentators thought that this would be a good idea. A relatively large body of opinion in the Republican period saw the tusi as governors who oversaw territory on behalf of the national government, but had no special claim to own land in that territory by virtue of their position. This allowed the government to argue that that land had always belonged to the state, and the hongzhao were merely some kind of Zhao Erfeng-esque state-tenancy managed by the tusi. Tu Zhongshan worried that recognizing hongzhao as deeds of full ownership would imply that the tusi had a right to sell land." ${ }^{89}$ If the tusi could sell land, this indicated that they owned it, and therefore, "giving into the hopes of a very small number of Han people would entail recognition that land occupied by the tusi is in fact owned by the tusi." ${ }^{90}$ Hence "the nation would lose a very large amount of land that was formerly public land

\footnotetext{
${ }^{86}$ Huang, Code, Custom and Legal Practice in China, 108-17.

${ }^{87}$ Ibid., 113.

${ }^{88}$ Xikang sheng canyihui, "Linshi canyihui, di yi ci hui huibian," 1940, (SCDAG, QZH:204, AJH:14), section 8, p. 12a.

${ }^{89}$ Tu Zhongshan 涂仲善, "Tiaozheng Kang qu di quan wenti zhi guan jian 調整康區地權 問題之管見," Xikang jingji jikan 西康經濟季刊 1, no. 8 (1944): 65.

90 Ibid.
} 
(gongyou 公有).”91 The government could presumably have argued that the hongzhao were state-tenancies that it generously had decided to convert into full ownership; but this would likely have encouraged other tenants to demand their own tenancies be converted into full ownership.

In 1939 Liu Wenhui ruled that the holders of hongzhao should be given government titles to "complete management rights" (guanye quan, gui bao hongzhao zhe suoyou 管業權, 歸包紅照者所有). ${ }^{92}$ This formulation seems calculated to include the emotional term “complete” suoyou 所有, but avoid “complete ownership” (suoyou quan 所有權). Possibly this was an attempt to keep both the settlers and the likes of Tu Zhongshan happy. Evidently there was some concern as to whether even this ruling would be implemented or not because the following year the Xikang Provincial Assembly resolved to:

Request that the provincial government order each county government to issue government titles to the holders of verified hongzhao, in order to clarify holders' rights to land. ${ }^{93}$

The assembly produced an initial statement that "this measure is vital for the protection of the people's land rights and to prevent their land from being illegally occupied." ${ }^{94}$ This statement was amended by resolution so that “land rights” (tudi quan 土地權) was replaced with “complete ownership rights” (tudi suoyou quan 土地所有權), further indicating the high degree of sensitivity over the precise nature of the land rights to be conferred on the Han farmers. ${ }^{95}$

In any case, some form of government issued title to very secure land rights replaced the hongzhao, breaking the relationship between tusi

\footnotetext{
${ }^{91}$ Ibid.

${ }^{92}$ Xikang sheng canyihui, "Linshi canyihui, di yi ci hui huibian," 1940, (SCDAG, QZH:204, AJH:14), section 8, p. 12a.

${ }^{93}$ Xikang sheng canyihui, "Linshi canyihui, di yi ci hui huibian," 1940, (SCDAG, QZH:204, AJH:14), section 8, p. 12.

${ }^{94}$ Ibid.

${ }^{95}$ Ibid.
} 
landlords and Han farmers. This was not a surprising outcome. The notion of greedy tusi seizing hongzhao from Han tenant farmers resonated with the images of Han being forced from their lands by the "Yi scourge". The fear of tusi capitulating to the shadowy forces of "outside capital” was probably a genuine motivation for the provincial government to seek to replace the tusi as the Han farmers' landlords as well. A certain amount of parochialism pervaded decision making by the Xikang provincial government. The Xikang Provincial Assembly's proposed regulations on mining stipulated that "in order to protect the rights and interests of locals", local people had to be given time to establish mining operations and ensure that existing operations were compliant with the law before mines could be established with “funds owned by other people” (ta ren jizi 他人集資; i.e. people from outside Xikang). ${ }^{96}$ Another regulation stated that joint public-private mining venture had to first offer stocks exclusively to Xikang residents, and then solicit "outside capital” only after a certain period of time had elapsed. ${ }^{97}$ Hence, the spectre of "capital from outside the province" taking land from locals probably raised some real alarm.

In sum, in the later Republican period, relationships manifest in hongzhao ended in three ways. Some tusi who profited by the renewed export of opium after 1936 bought off their tenants or bullied them into accepting the termination of the hongzhao. Other hongzhao were cancelled by the Xikang government and replaced by government issued titles. Only under the scenario that the tusi re-issued titles on new terms to other Han would the degree of contact between Han and Yi remain the same, but there is no evidence of this occurring on a significant scale. Because the new agreements were with the government rather than the tusi, there was no need for the settlers to have any form or relationship with the tusi.

\footnotetext{
${ }^{96}$ Ibid., section 8, p. 31a.

${ }^{97}$ Ibid.
} 
Evidence suggests that by the end of the Republican period there was less contact between Han and Yi than there was in at the end of the Qing dynasty. A background of ethnic tension certainly existed in the Qing. Arguably, the slave-owning, non-Buddhist Yi were more alien to Han than the Kham natives. However, the bitter conflict that saw the Han population of several locations decline significantly between 1918 and 1920 was not caused by inherent Yi savagery, or intractable ethnic tension between Yi and Han. The end of the late Qing boom in opium exports from Liangshan may have been an important factor, but, on balance, there is not enough evidence for the thesis that trends in trade were responsible for violence. The most important factor was the slashing of Sichuanese garrisons' budgets during the time of the Yunnanese occupation of Sichuan. This forced military commanders to seek more revenue from local communities, and it left large numbers of Yi mercenaries unemployed. These two factors transformed the low-intensity ethnic tension that had existed in the Qing into highly intense violence. This violence died down in the 1920s, though there were further episodes of serious conflict in some places.

I argue that this violence led to increasing ethnic segregation in Ningshu. Before it occurred there were "territories peopled by Chinese [...] governed by native princes." ${ }^{98}$ But such ethnically mixed territory was a causality of the conflict. Han writers tended to see this process as the expansion of the "the Yi territories (Yi qu 夷區). ${ }^{99}$ But what some writers referred to as “Han territory” (Han ren jingdi 漢人境地) probably also increased in size due to the collapse of ethnically mixed communities. ${ }^{100}$ As we saw in chapter one, even Liu Wenhui suggested that the "Yi scourge" had a "Han scourge" counterpart. In Xichang and other places Yi people were forbidden from staying in the town overnight. ${ }^{101}$ Goullart wrote that "It

\footnotetext{
${ }^{98}$ D'Ollone, In Forbidden China, 31.

${ }^{99}$ Zeng Zhaolun, Da Liang Shan Yi qu kao cha ji, 40, 68.

${ }^{100}$ Chang Longqing, Lei Ma E Ping diaocha ji, 17.

${ }^{101}$ Zeng Zhaolun, Da Liang Shan Yi qu kao cha ji, 36.
} 
was as unhealthy for a Lolo [Yi] to venture alone into big Chinese settlements as it was for the Chinese to intrude into Lolo territory." ${ }^{102} \mathrm{Yi}$ were prohibited from even entering some communities in Yunnanese Liangshan. ${ }^{103} \mathrm{Yi}$ needed the consent of the Han leaders to enter Han territory, just as the Han needed Yi consent to enter the Yi territory. Some ethnically mixed communities continued to exist, but sources mention such places and people far less in Ningshu than they do in the eastern edge of Kham.

As we have seen, the violence led to the recreation of Qing style security contracting agreements, which ensured there was at least some kind of relationship between Yi elites and the government. But this relationship was cast in primarily negative terms. The goal was to keep the Yi from bothering Han settlements. It did not involve Han authorities intervening in any way in $\mathrm{Yi}$ communities. Arguably, these security arrangements themselves contributed to greater ethnic segregation. Under this system, the $\mathrm{Yi}$ chiefs were primarily responsible for the prevention of $\mathrm{Yi}$ attacks on Han, which gave them a vested interest in keeping the communities apart.

The later Republican period was considerably more peaceful, but a trend toward greater ethnic segregation continued as hongzhao tenancy agreements between Yi chiefs and Han farmers broke down. This often resulted in either the Han farmers moving away or in the local Chinese government taking over the role of landlord.

What was the effect of this trend toward ethnic segregation on the development of the Chinese state in Ningshu? There was much less government engagement with indigenous communities in Ningshu than there was in many parts of Kham. This was not only a result of the increased ethnic segregation in Ningshu. In the previous chapter we saw how one of the effects of the wula problem was a highly managed relationship between Han county governments and indigenous authorities. Wula also forced the regional and local Han state to engage with indigenous communities in a way that would not have been necessary if the problems associated with the

\footnotetext{
${ }^{102}$ Goullart, Princes of the Black Bone, 107.

${ }^{103}$ Xiaolin Guo, State and Ethnicity in China's Southwest (Leiden: Brill, 2008), 224.
} 
tax had not existed. In Ningshu there was no equivalent problem and no body of regulation comparable to that governing wula was ever translated into Yi and disseminated among Yi communities. Government engagement with the Yi was typically limited to measures designed to defend Han settlements from Yi attacks.

In the period before 1939, the Sichuan government did plan the establishment of six schools in Ningshu specifically for the Yi. ${ }^{104}$ Only one of them, in Mianning, actually opened classes and was considered successful. As we saw in chapter three, state spending on education was, in relation to the number of students, significantly lower in Ningshu than in the eastern fringe of Kham. One of the explanations proposed in that chapter was that the government made greater, if often unsuccessful, efforts to get indigenous people to attend school in eastern Kham than they did in Ningshu. This thesis still requires more supporting evidence, but it fits well with the general conclusion drawn in this chapter that provincial government generally interacted less with indigenous communities in Ningshu than it did in Kham.

The government's lack of engagement with the Yi also affected the development of the local and regional government in the Han regions of Liangshan. In 1939, Liu Wenhui wrote of Ningshu that:

The government's orders only reach the Han people. [...] Because the government's orders are not disseminated to the Yi lairs, even in the Han regions in matters of opium prohibition, law and order, taxation, conscription and economic construction, the trend towards greater unity and centralization is weaker than the trend towards disunity. Criminals also find refuge in the Yi lairs. These problems constitute great obstacles, and because of them it is difficult to keep pace with the developments in the Interior. ${ }^{106}$

In the Qing dynasty, the investiture of indigenous leaders with offices was common on most of the empire's frontiers. As Giersch points out, there

\footnotetext{
${ }^{104}$ CKSB, 195.

${ }^{105}$ Literally, “centripetal forces are weaker than centrifugal forces”.

${ }^{106}$ Liu Wenhui, "Ningshu Yi wu wenti zhi jiantao," 3.
} 
has been a tendency among Chinese and foreign scholars to homogenize native officials under the rubric of a "native official system":

There were "native officials" (tusi) and Qing laws governing their appointments, but there was never a "native official system"; the term does not appear in Qing sources. [...] the relationship did not revolve around an intangible "system", but around individuals. ${ }^{107}$

A comparison of Kham and Ningshu illustrates the point that there was no unified "tusi system". But the relationship between the Chinese state and the tusi revolved around regional institutions, such as the wula tax and the security contracting arrangements of Ningshu, as well as around individuals. The different local institutions of the Qing period led to very different political challenges and developments in the Republican period, which fundamentally influenced the evolution of Han authority in the two regions in the twentieth century.

${ }^{107}$ Giersch, Asian Borderlands: The Transformation of Qing China's Yunnan Frontier, 11. The notion of a "tusi system" has been widely used however: Took uses the term in the introduction of her subject (Took, A Native Chieftaincy), as do many Chinese scholars. 


\section{Chapter Six: Han Migrants in the Frontier, 1905-1949.}

Thus far we have examined the development of Chinese regional and local authority in the Sichuan frontier, as well as the interaction of these bodies with indigenous communities. This chapter concentrates on the Han migrants in the highlands. Firstly, it details the magnitude of the increase in the Han Chinese population in various places. Secondly, it asks what brought Han migrants to the highlands, and how much their presence owed to the existence or policies of Han dominated local and regional authorities.

Governors and activist intellectuals hoped for a boom in Han migration that would rival the magnitude of nineteenth century British overseas settlement. Chen Zhongwei foresaw millions of eager pioneers settling on Xikang's virgin soil. ${ }^{1}$ Such prophets of explosive colonization were disappointed. Nevertheless, the Han population in the triangle between Kangding, Ya'an and Yuesui increased significantly; in some locations by around 2.7 times over the first half of the twentieth century. Beyond the triangle of strong Han population growth, there were further pockets of significant increase as well. This increase occurred at a time when the population in the Sichuan basin remained roughly stable and the population in the highlands of central China declined. ${ }^{2}$ In some parts of the latter region, the decrease in population was dramatic; a survey reported a decline in one district in eastern Sichuan from 1,900 households in 1912 to only 200 in $1937 .^{3}$

There is good evidence that unskilled but strong workers could earn significantly more in the western frontier highlands than they could in Chengdu and this was probably the most important reason for the population increase. Propaganda and a relatively strong ideological commitment to

\footnotetext{
${ }^{1}$ Leibold, Reconfiguring Chinese Nationalism, 198 n. 82.

${ }^{2}$ Ch'en, The Highlanders of Central China, 41-45. According to Ch'en the total Sichuanese population increased by 11 percent in the Republican period: it was not quite stagnant, but it grew much more slowly than the regions discussed in this chapter.

${ }^{3}$ Hsiang, C.-Y. "Mountain Economy in Sichuan." Pacific Affairs 14, no. 4 (1941): 453.
} 
settlement of borderlands within Chinese reformist activism might also have made a significant contribution, though it is harder to quantify.

\section{Population Trends}

Population estimates for places throughout the region vary considerably. For Dartsedo figures range from an early Republican estimate of 700 households ${ }^{4}$ to the figure of 45,000 people given in $1930 .^{5}$ The range is also extreme in the case of Xichang. The lowest estimate of 119,995 people comes from the 1947 Xikang Agricultural Improvement Institute figures. ${ }^{6}$ The highest is one in Sichuan Fronter Quarterly: 409,217 Han people in addition to 300,000 “settled barbarians” (shuyi 熟夷). ${ }^{7}$

The diversity of the figures reflects the large number of problems associated with producing them. One that is particularly relevant to our question about the numbers of Han people is the significant number of people of mixed parentage in some parts of eastern Kham, and, to a lesser extent, some parts of Ningshu. Goullart wrote of Kangding that "There was much intermarriage, both legalized and otherwise between Tibetans and Chinese, resulting in many half breeds, who were considered Tibetan or Chinese provided they wore appropriate dress and pursued either the Tibetan or Chinese mode of life.”8 Ren Naiqiang speculated that 90 percent of "Han" people in Kham were of mixed ancestry, as was one in five or one

\footnotetext{
${ }^{4}$ This is one of several estimates from different sources that Ren Naiqiang provides when discussing the same problem Ren Naiqiang, Xikang tujing: jingyu pian, 87.

${ }^{5}$ Like most of Chen's data, this is much higher than other estimates. However if his datawhich he probably did not collect himself-actually referred to the whole of Kangding County it would be roughly the same as some other estimates-though this cluster of estimates of a population around 40,000 contrasts with another cluster of estimates of around 20,000 souls. Chen Zhongwei, Xikang, 91-92.

${ }^{6}$ Xikang sheng nongye gaijinsuo 西康省農業改進所, "Xikang sheng tudi hukou diaochabiao 西康省土地戶口調查表," 1947, (SCDAG, QZH: 249, AJH: 152).

${ }^{7}$ Liu Shangxin 劉尚新, "Ningshu jishi 寧屬紀實," Chuanbian jikan 1, no. 4 (1935): 19293.

${ }^{8}$ Peter Goullart, Princes of the Black Bone, 18.
} 
in six of the total population of Kangding. ${ }^{9}$ Ren was the only surveyor I have encountered who attempted to count the mixed population separately from what he called “pure Han” (chun Han 純漢) and “pure Fan [Tibetan]” (chun Fan 純番), and he only attempted it once among all his population counts. ${ }^{10}$ For either ideological or practical reasons, more normal practice appears to have been to count households that were obviously mixed as Han, as Ren did on other occasions. ${ }^{11}$ Of course, the non-Han totals probably also included substantial numbers of people with mixed ancestry too-especially given that, as many reporters noted, there were "Han" households and people who had been "native-ized” (man hua 蠻化). ${ }^{12}$ "In the mixed regions (za chu 雜處) the Han are somewhat Kham-ized (Kang hua 康化) and the Khampas are somewhat Han-ized (Han hua 漢化).”13 The missionary Flora Shelton, who was in Bathang in the 1900s and 1910s even wrote that "If [Han] remain long in Tibet, they are absolutely swallowed up by Tibetan customs [...] The Tibetan race Tibetanizes the Chinaman who makes Tibet his home."14 The research subjects themselves were also active participants in this process of ethnic identification. Ren noted that "Those Fan [Tibetan] people who are related by some marriage connection to Han people, all like to call themselves Han. Therefore the

\footnotetext{
${ }^{9}$ Ren Naiqiang, Xikang tujing: minsu pian, 234; Ren Naiqiang, "Kangding xian shicha baogao 康定縣視察報告," Bianzheng 邊政, no. 2 (1929), reprinted in Zhao Xinyu and Qin Heping, eds., Kangqu Zangzu shehui lishi diaocha ziliao jiyao, 262.

${ }^{10}$ Ren Naiqiang, "Kangding xian shicha baogao," 261.

${ }^{11}$ Ren Naiqiang, Xikang tujing: jingyu pian, 87. Another example is Wu Wenhui's report of landownership in Kham, where information on Han farmers was combined with "Hanized Kham people”; Wu Wenhui 吴文暉 and Zhu Jianhua 朱鑒華, "Xikang tudi wenti 西 康土地問題," Bianzheng gonglun 邊政公論 3, no. 6 (1944): 22. The practical motivation for counting mixed households as Han would be that a "mixed" category would be difficult to define if the surveyors were mostly making judgments based on how people lived and what language they spoke. Some researchers probably assumed that, even if mixed households or "Han-izing" natives were not yet fully 'assimilated', they would be in the near future. Ren Naiqiang argued that of all the minorities in China the "Fan" would be the easiest minority in China to assimilate. (Ren Naiqiang, Xikang tujing: minsu pian, 219-22.)

${ }^{12}$ See. Ke Xiangfeng 柯象峰, "Xikang ji xing (xu wan) 西康紀行 (續完)," Bianzheng gonglun 邊政公論 1, no. 8-9 (合刊) (1942): 87; Chen Zhongsheng, Xi xing yan yi ji, 120.

${ }^{13}$ CKSB, 427.

${ }^{14}$ Flora Shelton, Shelton of Tibet, 101.
} 
results from the survey show that there are seven times more Han than nonHan ( $Y i$ 夷). In reality the numbers [of Han and non-Han] are roughly even.” 15 Chen Zhongsheng, who adopted the slightly less orthodox ethnographic practice of sleeping with an abundant number of the females of his research population (or at least claiming that he did), examined the skin of three women in a community of tea growers in Yazhou. He concluded that "Their identification of themselves as Han, is merely a matter of their envying the Han (xianmo Hanzu 羡慕漢族).” ${ }^{16}$ Chen’s research methods were dubious, and Ren Naiqiang was exceptionally scornful of Chen's work. Nevertheless, Chen grasped the important fact that ethnic identity is not the same as genetic heritage.

In addition to the vagaries of ethnic classification, several other factors influenced population counts. Different writers used different methods, and were more or less methodical. Town populations were probably easier to estimate than dispersed rural populations. However, in the case of estimates of town populations, different surveyors may have understood the borders of towns differently. In many places, there was, as Stevenson notes of Dartsedo, a "large floating population of transient merchants, traders, officials, and caravan men”. ${ }^{17}$ Some sources may have included such people, while others deliberately excluded them. Some researchers counted households, while others counted individuals, and others counted households and then used a formula to convert this total to an individual total. Ren Naiqiang appears to have done this on a number of occasions, assuming that there were roughly ten people per household. ${ }^{18}$ It is uncertain why Ren believed ten people per household was average, as this is far higher than the China-wide average, which Freedman states was between five and six. ${ }^{19}$ Other researchers indicate that household sizes were even

\footnotetext{
${ }^{15}$ Ren Naiqiang, Xikang tujing: jingyu pian, 87.

${ }^{16}$ Chen Zhongsheng, Xi xing yan yi ji, 122.

17 Paul Huston Stevenson, "Notes on the Human Geography of the Chinese-Tibetan Borderland," Geographic Review 22, no. 4 (1932): 616.

${ }^{18}$ Ren Naiqiang, "Kangding xian shicha baogao." 261.

${ }^{19}$ Maurice Freedman, The Study of Chinese Society: Essays by Maurice Freedman, selected and introduced by G. William Skinner (Stanford: Stanford University Press, 1979), 235.
} 
smaller in the Sichuan frontier-as would be expected given the large number of sojourners, soldiers and merchants. Some researchers may have also converted household totals to individual totals, or vice-versa, but used different formulas.

Qualitative data is an important aid to sorting out the more and less realistic population estimates. If writers' observations led them to report that a certain place had either grown or shrunk in recent years, in most cases it is reasonable to believe them. Numbers may be suspect for many reasons, but it is harder to be skeptical about impressions of demographic change based on observations of new houses being built, new lands being cultivated—or alternatively, reports of abandoned housing and fields. Such descriptions provide a good starting point for our analysis of the range of population estimates.

The descriptive data from the eastern fringe of Kham indicates an increase in the Han migrant population starting in the late Qing period; possibly dating from before the onset of Zhao Erfeng's campaigns and development program. In 1916 British geographer Oliver Coales wrote:

There is a gradual infiltration of Chinese settlers in the Dau [Dawu] and Drango districts where in the low-lying parts of the valley of the She Ch'u land neglected by Tibetans is being brought under cultivation. Dau is a semi-Chinese town and below Drango a purely Chinese colony has sprung up, the greater part of which is Christian. Beyond Drango there are a few Chinese on the soil but at Kanze there are two or three score of petty traders who have attached themselves to Tibetan families through their wives. The latter is a very common practice. [...] Flour mills at Kanze are monopolized by Chinese. Carpentry [...] is also in the hands of Chinese. ${ }^{20}$

In 1933, Ren Naiqiang wrote that: "Fifty years ago, the number of paddy fields in Luding was less than a fifth of what it is today and Dartsedo did not even have one stretch of cultivated land.”21 In the same work, Ren gave several brief biographies of settlers who arrived in the late Qing or early

\footnotetext{
${ }^{20}$ Oliver Coales, "Narrative of a Journey from Tachienlu to Ch'amdo and back via Batang," 221.

${ }^{21}$ Ren Naiqiang, Xikang tujing: minsu pian, 254.
} 
Republic. ${ }^{22}$ Ren also described the settlements that sprung up around mines near Darstedo and Danba.

In the past, mining west of Zheduo Mountain was prohibited by Lamas. In the reigns of Guangxu (1875-1908) and Xuantong (1909-1911), the Dartsedo government petitioned the Court to have this prohibition lifted. They recruited people to mine, and in a short time a mining industry was flourishing. Places such as Rongcha Gulley and Tonglufang in Danba and Kongyu and Yutong in Kangding all had hundreds of tents of miners, and merchants from everywhere selling salt, grain, oil and other daily necessities. Houses, markets, native-place associations (huiguan 會館) and shrines to Guandi were built. Land cultivation (kenshi 墾事) also rose correspondingly [...] After four or five years the [placer gold in the] land for tens of $l i$ around each settlement was exhausted [...] Most miners drifted about destitute and unable to return home. By this time they were able to understand the native language (fan yu 番語) and they settled in the borderlands, taking up farming (ling ken 領墾). This was the fate of most [Han at the mining settlements]. For this reason, wherever there are abandoned mines there are usually Han villages. ${ }^{23}$

In 1930, Chen Zhongwei reckoned that overall about five percent of the Kham aristocracy's income came from mortgaging land to Han settlers. ${ }^{24}$ The figure is immensely suspicious, but the statement does indicate that in some places there was a non-trivial incidence of Han using land acquired from native elites.

The small Han population at Bathang that had been established during Zhao Erfeng's reign declined due to the conflict that peaked around 1918. The displaced people did not necessarily leave the frontier, however. When Wu Zizhong and his wife were forced out of Yanjing in 1911, they settled nearby in a place that is also in the modern Tibetan Autonomous Region. ${ }^{25}$ Moreover, where conflict led to depopulation, there is evidence that people returned relatively quickly when stability improved. By the 1930s Han

\footnotetext{
${ }^{22}$ Ibid., 62-3, 256-78.

${ }^{23}$ Ibid., 252-53.

${ }^{24}$ Chen Zhongwei, Xikang wenti, 146.

${ }^{25}$ Ren Naiqiang, Xikang tujing: minsu pian, 267.
} 
people were returning to Bathang. ${ }^{26}$

Among the numerical chaos of population estimates for Dartsedo, there are some broad trends. Most surveyors did not include military garrisons, and I believe that none of the following figures do. ${ }^{27}$ Ren quoted two government sources from the 1910s which put the town population at 700 households and 900 households respectively. ${ }^{28}$ According to a foreign traveler who visited in 1894, there were about 800 houses in that year. ${ }^{29}$ Elsewhere, Ren mentioned "old tax records" that gave a population of 2,411. ${ }^{30}$ A cluster of estimates from the mid 1920s and early 1930s suggests that by this time the population had roughly doubled. A foreign traveler visiting in 1924-1925 said there were about 5,000 people. ${ }^{31}$ In 1929 , Ren Naiqiang proposed 1,500 households (including surrounding villages). ${ }^{32}$ The Chinese Academy of Sciences in the Western Regions (Zhongguo xibu kexueyuan 中國西部科學院) conducted research in 1930 and found that there were 4,256 people who had been resident for six months or more, in 1,108 households. ${ }^{33}$ In 1934, at least two organs of the Xikang administration were using a figure of 1,628 households. ${ }^{34}$

There is contradictory evidence regarding trends in migration in the mid-1930s. Some sources suggest that growth slowed or stopped at this time. Demand for highland products like wool, hides and medicines dropped markedly during the Great Depression. ${ }^{35}$ The population of Luding is

${ }^{26}$ Ba ren 巴人, "Xikang de xin Ba'an 西康的新巴安," Kangdao yuekan 康道月刊 4, no. 4 (1943): 78; Ren Naiqiang, Xikang tujing: minsu pian, 254.

27 Ibid., 241.

${ }^{28}$ Ren Naiqiang, Xikang tujing: jingyu pian, 87.

${ }^{29}$ H. R. Davies, Yün-nan, the link between India and the Yangtze, 292.

${ }^{30}$ Ren Naiqiang, "Kangding xian shicha baogao," 260.

${ }^{31}$ Wim van Spengen, Tibetan Border Worlds: a Geohistorical Analysis of Trade and Traders (London; New York: Kegan Paul International, 2000), 108.

${ }^{32}$ Ren Naiqiang, "Kangding xian shicha baogao," 261.

${ }^{33}$ Ren Naiqiang, Xikang tujing: jingyu pian, 87.

${ }^{34} \mathrm{JKDZ}, 183$.

35 Tim Wright, "Distant Thunder: The Regional Economies of Southwest China and the Impact of the Great Depression," Modern Asian Studies 34, no. 3 (2000): 716. 
reported to have declined due to banditry in the couple of years following the Sichuan famine of 1936, though it recovered by $1939 .{ }^{36}$ On the other hand, trends in the value of the deed tax, which was collected as a percentage of the value of real estate transactions, suggest a continuous population increase in Kangding over the 1930s. As we saw in chapter three, even though there was no change in the tax rates, the value of the deed tax as a percentage of the value of the land tax more than doubled between 1932 and 1939. The increase in land values relative to inflation as measured in grain prices (which climbed through the 1930s, but more slowly) indicates an increase in the demand for land; a probable indicator that the population was increasing.

Many reports from the late 1930s and 1940s indicate a rapid increase in population in the war and post-war periods. ${ }^{37}$ A Xikang Agriculture Improvement Institute paper made the typical comment that in the $1940 \mathrm{~s}$ "commerce in Kangding has boomed and the population has grown larger and larger."38 Police records from September 1939 show that in that month 231 people moved into the urban area of Dartsedo (while 53 moved out). ${ }^{39}$ In 1939, Kangding's government planned to spend 20,000 yuan on the construction of a new district for the town. ${ }^{40}$ In 1939 the report from the Guomindang's Sichuan and Xikang Investigation Team stated that in Kangding County there were 15,000 “farmers", 2,500 “merchants" and 3,700 "workers". ${ }^{41}$ We can presume that the latter two categories were urban residents of the town, but some of the former were likely suburbanites, who would have been included in some of the earlier estimates

\footnotetext{
${ }^{36}$ CKSB, 409-10.

${ }^{37}$ See for example Xikang jingji jikan, 1, no. 7 (1942), 152; Xikang jingji jikan, 1, no. 5-6 [combined issue] (1942), 30-31; Also Xikang sheng canyihui 西康省參議會, "Linshi canyihui, di er jie, di yi ci hui huibian 臨時參議會第二屆, 第一次會匯編," 1943, (Shanghai Municipal Library), p.40.
${ }^{38}$ Xikang sheng nongye gaijinsuo 西康省農業改進所, "Kangding Yalatuo huangdi tunken jihua 康定亞拉沱荒地屯墾計劃," 1949, (SCDAG, QZH: 249, AJH:152).

${ }^{39}$ Xikang zhengfu gongbao 西康政府公報 no.9 (Sept. 30, 1939) unpaginated tables.

${ }^{40}$ CKSB, 409.

${ }^{41}$ Ibid.
} 
above. This gives somewhat over 6,000 town residents, which is consistent with the figure of 7,000 that officials told A. Doak Barnett when he visited in $1948 .^{42}$ Therefore, we have the overall impression that Darstendo increased throughout the first half of the twentieth century from possibly 2,500 people to around 7,000, or by a factor of around 2.8.

Population estimates for Kangding and Luding counties suggest that growth of this magnitude was not confined to the Dartsedo town area in the 1930s and 1940s (there is no useful data for the non-town population from before the 1930s). In 1930, Feng Yunxian recorded 1,700 “Han” households in Kangding and 6,280 in Luding. ${ }^{43}$ In 1933, Ren Naiqiang recorded 1,800 in Kangding and 7,000 in Luding. ${ }^{44}$ Post-war figures appear-for unknown reasons - less likely to divide population statistics according to ethnicity. In 1945, the provincial Bureau of Civil Affairs (Minzheng ting 民政廳), gave a total inclusive of all ethnicities of 6,825 households in Kangding and 5,409 in Luding (the bureau probably used a different boundary between Kangding and Luding). ${ }^{45}$ By the Republican period, most settlements in Luding were identified as Han. Estimates of the ratio of Han to indigenous people in Kangding swing back and forth wildly, according to estimates of the indigenous population, ethnic classification methods and administrative boundaries. One post-war government report suggested that sixty or seventy percent of Kangding's population were Han. ${ }^{46}$ Sixty-five percent of the Kangding households (as given by the Bureau of Civil Affairs) plus the Luding households comes to a total of 9,845 Han or mixed-race households in the post-war period. This represents an increase of roughly seventeen percent from Ren and Feng's figures of fifteen years earlier.

Reports from the more remote parts of Kham also indicate that migration to places further afield than Kangding continued in the late Republican period. In 1939, an official commented on the "steady

\footnotetext{
${ }^{42}$ A. Doak Barnett, China's Far West, 443.

${ }^{43}$ Ren Naiqiang, Xikang tujing: minsu pian, 15-18.

${ }^{44}$ Ibid.

45 JKDZ, 191.

${ }^{46}$ Ibid., 227.
} 
flourishing of agricultural settlement” in Gyaisi (Ch. Jiulong 九龍), containing 1,184 Han households in Gyaisi; up from none in the Qing period. ${ }^{47}$ Dawu County's Taining Experimental Region, the site of the large government ranch initially established for the Animal Transport Company also experienced a population increase; from 1,327 people in 1937 to more than 4,700 in $1943 .{ }^{48}$ In 1933, Ren Naiqiang estimated that there were 5,000 Han people in Danba and 13,000 elsewhere in places such as Bathang, Dawu, and Drango. ${ }^{49}$ Yang Zhonghua's 1937 population figures and estimates of percentage Han in these places suggest a total Han population of 38,000 beyond Luding and Kangding. ${ }^{50}$

In the 1940s, a journalist reported that "every year a steady of adventurers heads forth to mine gold." ${ }^{51}$ Peter Goullart wrote that in 1939 "Alluvial gold was to be found [...] almost everywhere in Sikang highlands, and so were these gold panners, mostly Szechuanese Chinese. They were everywhere-in small groups of two or three and singly." 52 In addition to loners and small bands, there were also larger mines, some of which were worked by over 3,000 miners during their peaks. ${ }^{53}$ However, these generally did not last very long and numbers of miners at any single location fluctuated greatly from year to year. At a single mine in Dawu there were between five and six hundred miners in 1932, around 170 a year later, and between seven and eight hundred in $1935 .^{54}$ 'Several thousand' miners in Kham might be the best possible estimate. ${ }^{55}$

\footnotetext{
${ }^{47}$ Qiu Shuling, "Jiulong jingji jianshe zhi yantao," 40, 42-43.

${ }^{48}$ Shang Cheng 尚誠, "Kangbei de shengdi -- Taining 康北的聖地 -- 泰宁," Kangdao yuekan 5, no. 5 (1943). in Zhao Xinyu and Qin Heping, eds., Kangqu Zangzu shehui lishi diaocha ziliao jiyao, 220; Dao Xue, "Xikang Taining shiyanqu diaocha," 213.

${ }^{49}$ Ren Naiqiang, Xikang tujing: minsu pian, 241.

${ }^{50}$ Yang Zhonghua, Xikang ji yao, 144-151.

${ }^{51}$ Shi Wen, "Xikang wei Zhongguo yin lai de san da wenti," 11.

${ }^{52}$ Goullart, Princes of the Black Bone. 46.

53 See Kangdao yuekan 1, no. 7 (1939) un-paginated tables after page 48; also Ren Xinjian, "Jindai Sichuan Zang qu de huangjin kaifa, " 47.

${ }^{54}$ ZYDZ, "Diaocha ziliao," Chuanbian jikan 1, no. 1 (1935): 157.

${ }^{55}$ See Kangdao yuekan 1, no. 7 (1939) un-paginated tables after page 48.
} 
Turning to Ningshu, as we saw in chapters one and five, many reports indicate that Han settlements on the fringes of Liangshan were devastated by the conflict that began around 1918. But as was the case in Bathang, refugees did not necessarily go very far. In chapter five, I argued that while "Yi territories" might have expanded, some of the "Han territories" probably did too. When conflict died down in the 1930s, Han settlers returned to areas of Liangshan that they had previously abandoned just as they did in Bathang. Lin Yueh-hua described settlements that had reappeared on land abandoned in the early Republican conflict with the Yi, though full recovery had not yet occurred by the time of his visit in $1943 .{ }^{56}$ In 1939, Liu Wenhui commented that in the previous ten years Han people had returned to some of the places near Xichang that they had abandoned during violence in the early Republican period. ${ }^{57}$ A 1947 survey reported “certainly some land has been abandoned due to banditry. However the area of such land is not great. It is not worth initiating a large scale campaign for its reclamation." 58

It is uncertain whether and to what extent the back-and-forth nature of settlement in some places affected the final numbers of Han settlers in the whole region at the end of the Republican period. It was not only Han Chinese who were victims of conflict. Indigenous people were also forced from homes by bandits, renegade soldiers or local rivals. ${ }^{59}$ Abandoned fields did not only signal the effects of Han fleeing the "Yi scourge":

The authority of some tusi has declined and they are often unable to get their people to cultivate the land. In some cases, defeats by the military have broken the power of the tusi, so there is nothing they can do when their people rebel and refuse to farm land for them. Because of this much land has been abandoned and gone huang. ${ }^{60}$

\footnotetext{
${ }^{56}$ Lin Yueh-hua, The Lolo of Liangshan [Liangshan yi jia 凉山夷家], trans. Ju-Shu Pan, (New Haven: HRAF Press, 1961), 13-14.

${ }^{57}$ Liu Wenhui, "Ningshu Yi wu wenti zhi," 3.

${ }^{58}$ Zeng Zhaolun, Da Liang Shan Yi qu kao cha ji, 21.

${ }^{59}$ See for example report from magistrate of Wang Jinchen 王藎臣 to the Sichuan Frontier Region Sheriff (Chuanbian daoyin 川邊道道尹, Chuanbian dao gongshu 川邊道公署; (SCDAG, QZH:196, AJH:8).

${ }^{60}$ Wu Wenhui and Zhu Jianhua, "Xikang tudi wenti," 11.
} 
Violence could facilitate colonization, as well as impede it. Indeed, the mass settlement of the Americas and Australasia by Europeans could hardly have happened without violent conflict.

The available population data from Yuesui suggests that there was a significant increase in the Han population of that county. The 1906 Yuesui Gazetteer reported a population of 10,922 households, a figure which probably only included households that seemed mostly Han or not too distinct from surveyors' ideas of Han-ness. ${ }^{61}$ I have not found any early Republican period estimates, but there is a cluster of figures from the 1930s. In 1935, an article in Chuanbian Quarterly reported that the Han population numbered 15,803 households or 56,376 people. ${ }^{62}$ This report indicated a total of 24,600 “settled Yi-barbarian” ( shu Yi 熟夷) individuals and an unknown number of “wild Yi-barbarians” (sheng Yi 生夷). This is roughly the same as the Yuesui County government's count and another survey done during the early 1930s, although the Twenty Fourth Army gave a higher figure in its 1929 count. ${ }^{63}$ Growth appears to have continued throughout the 1930s because in 1939 the GMD survey team estimated that there were about 83,000 Han people, which would suggest around 18,500 households if there were an average of 4.5 people per household. ${ }^{64}$

Hanyuan, just across the northern border of Ningshu was similar to Luding, in that the identification of its population as 95 percent Han in the 1930s masked a much more diverse reality. ${ }^{65}$ Goullart wrote that the magistrate "has tribal blood in his veins [...] He is extremely pro-Lolo." The man’s adopted Yi son, whose Chinese name was “Electric” Leng 冷光佃電,

\footnotetext{
${ }^{61}$ Ma Zhongliang and Sun Qiangzeng, "Yuesui ting zhi," 88.

62 ZYDZ, "Diaocha ziliao," Chuanbian jikan 1, no. 4 (1935), 192.

63 Junshi weiyuanhui weiyuanzhang xingying bianzheng sheji weiyuanhui 軍事委員會委 員長行營邊政設計委員會, "Chuan-Kang bianzheng ziliao jiyao 川康邊政資料輯要," in Minguo Zang shi shi liao huibian 民国藏事史料汇编, ed. Zhang Yuxin and Zhang Shuangzhi 张雙志 (Beijing: Xuefan chubanshe, 2005 [1940]), 75.

${ }^{64}$ CKSB, 186.

${ }^{65}$ ZYDZ, "Diaocha ziliao," Chuanbian jikan 1, no. 4, 273.
} 
controlled traffic through Hanyuan and was called a tusi by Chinese visitors. ${ }^{66}$ The county's population apparently remained stable at just over 50,000 in the late Qing and early Republic, but some figures show it increasing quite quickly from the 1920 s or early 1930s, reaching an estimated 69,300 in $1935 .{ }^{67}$ In 1947 it was recorded as $104,189 .{ }^{68}$

Statistics from Xichang are particularly diverse, as noted above, but there is descriptive evidence of an increase in migration to Xichang in the late Republican period. "From the war-era, the city began to transform itself into a modern metropolis (dushi 都市). There has been a great influx of professionals (renshi 人士) from other provinces. Modern garments are seen everywhere." 69

In other regions the Han population appears to have remained stable throughout our period. In Mianning, the population in the areas where Han people lived (which presumably included some $\mathrm{Yi}$ too) was listed as 102,066 in $1916 .^{70}$ In 1953 the Han population was listed as 99,738. ${ }^{71}$

In sum, over the whole period from 1905 to 1949, the Kangding-Luding region probably gained around 25,000 Han people, assuming that the growth rate of Dartsedo town is representative of the less well surveyed Han townships that sprung up in Kangding and Luding counties. Elsewhere in Kham there were probably at least another 20,000 more souls of Han or mixed ethnicity in 1949 than there had been in 1905. Yuesui may well have gained up to 35,000 , and it would be plausible to suggest similar or greater increases around Hanyuan. The general picture for the Chuanbian region in the period from 1905 to 1949 is one of important settlement growth in

${ }^{66}$ Zeng Zhaolun, Da Liang Shan Yi qu kao cha ji, 53; see also Goullart, Princes of the Black Bone, 115.

${ }^{67}$ Chongqing Zhongguo yinhang diaocha zuzhi, "Ebian diaocha 峨邊調查," Chuanbian jikan 1, no. 3 (1935): 53-54; —_,"Diaocha ziliao," Chuanbian jikan 1 no. 4, 273.

${ }^{68}$ Xikang sheng nongye gaijinsuo, "Xikang sheng tudi hukou diaochabiao," 1947, (SCDAG, QZH: 249, AJH: 152).

${ }^{69}$ Zeng Zhaolun, Da Liang Shan Yi qu kao cha ji, 34.

${ }^{70}$ Sichuan sheng Mianning xian difang zhi bianzuan weiyuanhui 四川省冕宁县地方志编 纂委员会, ed. Mianning xian zhi 冕宁县志 (Chengdu: Sichuan minzu chubanshe, 1994), 131.

${ }^{71}$ Ibid., 146. 
certain areas. This was not the explosive colonization that many frontier leaders hoped and planned for. Nor was it as dramatic as the incredible migrations into Sichuan (including Ningyuan Prefecture) during the eighteenth and early nineteenth centuries. ${ }^{72}$ However, those earlier waves of settlement occurred against the background of a doubling of the whole Chinese population. By contrast, the more modest twentieth century growth of colonies in the Sichuan frontier grew at the same time that the population fell or remained static elsewhere in the country.

Factors affecting migration (I): Han Law and Order.

How important was the mere existence of the relatively stable Han Chinese authority that existed in the Jianchang valley, around Kangding and Ya'an and between those places? Firstly, Han government authority was not absolutely necessary for migration to occur. There were Han people in places where there was no meaningful Han local state authority at all. In $1940 \mathrm{Xu}$ Xiaohui, the vice-director of the provincial government's Xikang Agriculture Improvement Institute commented on the government of the Tibetan tusi in Muli:

[His authority is] stern and exacting, but although migrants’ (kemin 客 民 [lit. "guest people"]) suffer under heavy burdens, they need not worry about the preservation of law and order. Because of this the peasants who are stricken by the Yi scourge often come here for refuge. $^{73}$

An article in Bianjiang gonglun also reported that banditry was not a problem in Muli and that there were migrant farmers present in the tusi's

\footnotetext{
${ }^{72}$ According to Perkins' statistics there were around 3 million people in Sichuan in 1771. By 1776 there were 7.7 million; by 1819, there were 25.6 millions. The population had increased eight-fold in only fifty years. Over the following fifty years, it doubled again. Dwight H. Perkins, Agricultural Development in China, 207.

${ }^{73}$ Xu Xiaohui 徐孝恢, "Ningshu ge xian nongye gai guan 甯屬各縣農業概觀," Kangdao yuekan 2, no. 12 (1940): 37.
} 
domain. ${ }^{74}$ Xikang jianying's report on the merchants-particularly those from Shaanxi-also demonstrates that areas beyond the control of the provincial government in Kham were not necessarily dangerous.

As long as they don an outfit in the Kham style, the Han merchants find no severe problems with security while traveling in the Kham region Staying on familiar routes and maintaining friendly relations with the local good-for-nothings, the merchants are able to go anywhere without fear of danger. The Kham people are very welcoming towards this kind of trader, who does not require them to go very far from their homes, but wears their clothes, speaks their language and carries things that they are in need of [...] Because of this Shaanxi merchants have traversed even the domains of those remote tribes where government power does not reach. [...] Even when the political situation was at its most chaotic, they were still able to cross the Jinsha River to conduct trade in Tibet. ${ }^{75}$

As this passage indicates, whether a certain place was dangerous or not probably depended a lot on how one behaved and what one wanted to do there. In general, Ningshu may have been somewhat more dangerous than Kham, but the same rule still applied. There is substantial evidence that travellers and residents were able to prevent harm to themselves by maintaining good relations with the locals. Indeed, such practice was regularized into a customary form of exchange according to which outsiders made agreements with Yi chiefs who would guarantee their safety. A typical example of this is recalled in the testimony of a merchant who did small trade by exchanging Sichuanese salt and needles for Liangshan animal products. "When Han people from outside went into the Yi regions to trade or do other things, they would be safe enough as long as they had a protector (baotou 保頭) to guarantee their safety.” ${ }^{76}$ According to $\mathrm{Hu}$ Chaojun, merchants paid between one and ten percent of their goods to obtain such a guarantee of protection. If the baotou fees are viewed as

\footnotetext{
${ }^{74}$ Wu Wenhui and Zhu Jianhua, "Xikang tudi wenti," 15, 17.

${ }^{75}$ Cheng Yuqi 程裕淇, Xikang jianying 西康剪影 (Duli chubanshe, 1945), 25.

${ }^{76} \mathrm{Hu}$ Chaojun 胡朝均 and Li Jing 李静, "Wo zai Yi qu jingshang de jingyan 我在彝区经 商的经验," in Liangshan Yizu wenshi ziliao zhuanji 凉山薮族文史资料专辑, ed. Yang Ling 杨凌 and Chen Hua 陈华 (Chengdu: Sichuan minzu chubanshe, 2000), 73.
} 
customs levies, the Yi chiefs were hardly more extortionate than the Xikang government, which also collected customs tax on goods entering and leaving the province. The official rates were up to five percent of the value of goods taken out of the province, seven and a half percent for everyday goods imported into the province, 12 percent for imported luxury goods and an extra two percent on foreign goods. ${ }^{77}$ Having paid the baotou fee, $\mathrm{Hu}$ found the Yi with whom he had dealings to be "very hospitable (feichang haoke 非常好客)”. In a passage that illustrated both the dangers outsiders faced in Ningshu and the possibility of managing them, Peter Goullart wrote:

Here a small colony of Chinese merchants lived and carried on their business, despite an ingrained terror of the Lolos [Yi]. The position was altogether anomalous. [...] the Chinese could not enter Lololand unless they had a special passport from one of the princes. [...] The Chinese merchants at Dienba had such passports from Prince Molin and, in fairness to the Lolos [Yi], they were strictly respected. If the Chinese were peaceful citizens and stuck to their legitimate trade, they had nothing to fear. [...] The Lolos, contrary to expectation, did not kill or enslave bona fide residents, but let them live and trade under special guarantee from the ruler."78

Zeng Zhaolun made a very similar comment. ${ }^{79}$ The practice of making agreements with chiefs involving some kind of payment in exchange for security is also mentioned by Fergusson and D'Ollone, and then forty years later by Covell and Lin Yueh-hua. ${ }^{80}$ These writers all use the term 'baotou' to describe such agreements.

\footnotetext{
${ }^{77}$ Xikang sheng canyihui 西康省參議會. "Linshi canyihui, di yi ci hui huibian 臨時參議會 第一次會匯編," 1940, (SCDAG, QZH: 204, AJH: 14), 'sheng zhengfu shizheng baogao 省政府施政報告, p.15. The report does not indicate how a “luxury good” was defined.

${ }^{78}$ Goullart, Princes of the Black Bone, 135-36.

${ }^{79}$ Zeng Zhaolun, Da Liang Shan Yi qu kao cha ji, 53.

${ }^{80}$ Ralph Covell, Mission Impossible: The Unreached Nosu on China's Frontier (Pasadena, California: Hope Publishing House, 1990), 87.; W.N. Fergusson, Adventure, Sport and Travel on the Tibetan Steppes (London: Constable and Company, Ltd., 1911), 303; Lin Yueh-hua, The Lolo of Liangshan, 17.
} 
The existence of Chinese state authority at a local level was neither a necessary nor a sufficient condition for Han migration to a particular region. Nevertheless, the largest increases in Han population were all in places were there was a functioning Han dominated local state authority. However, establishing cause and effect relationships here is difficult. Were migrants more likely to go to a place where the authorities were of the same ethnicity as themselves? It seems likely that they were, but it is hard to know how much more likely. Goullart described a couple of teachers working in Liangshan, employed by Electric Leng:

At first they thought Prince Molin was a real Chinese when he offered both of them a job with decent pay and quarters in Dienba. They gladly accepted, having little idea of the remoteness of the place and the savage conditions of life among the barbarian tribes. They did not regret their coming here, but, they confessed, they were still frightened and unable to get rid of a gnawing, debilitating dread of the Lolos which poisoned their otherwise peaceful and uneventful lives. ${ }^{81}$

Would the couple have still gone if they had known that Prince Molin was not a "real Chinese" like they had assumed? It is difficult to quantify such a preference. Given the enormous subsidy and opium related income wielded by the provincial government, there were almost certainly more job opportunities in the places where provincial authority was strongest; this may have been more important in determining trends in migration than ethnic preference. Furthermore, it is also quite possible that local Han authorities were more likely to become well and securely established in places where there were already more significant migrant communities. The two processes, Han migration and Han state-building, probably reinforced each other.

${ }^{81}$ Goullart, Princes of the Black Bone, 131. 
Factors affecting migration (II): Trade, Work and Income

We have already noted a couple of the pursuits that drew migrants to the highlands: gold-mining and medicine gathering. Jobs associated with trade between the highlands and lowlands were also an attraction. In 1915, Oliver Coales calculated that Dartsedo saw 160,000 pounds sterling of worth of east-going musk and 170,000 pounds worth of west-going tea annually; the value of the former trade was enough for two French perfume firms to maintain representatives in the town. ${ }^{82}$ Musk was worth 380 yuan per jin in Kangding in $1938 .^{83}$ According to Barnett, at the end of the Republican period musk and tea were still the two most important articles of commerce, followed by medicines of various kinds. ${ }^{84}$ Trade between the Sichuan basin and Ningshu was also significant, Ningshu's most important products being wood for coffins, and, in the late Republican period, opium, as we saw in chapter one. $^{85}$

Different goods rose and fell in their importance over the period of this study. As we saw in chapter five, wax for candle manufacture was a highly important export from Ningyuan in the mid-Qing era, but demand slackened as kerosene oil replaced candles at the end of the nineteenth century. ${ }^{86}$ Throughout the period focused on in this study, Chinese officials feared that tea grown in India would out-compete Sichuanese tea in Tibet. ${ }^{87}$ In fact,

${ }^{82}$ Oliver Coales, "Economic Notes on Eastern Tibet," The Geographic Journal 54, no. 4 (1919): 244.

${ }^{83} \mathrm{Gu}$ Xueqiu 顾学表, "Xikang sheng yaocai diaocha baogaoshu 西康省药材调查报告书," (1939) in Zhongguo Zangxue yanjiu zhongxin 中国藏学研究中心 and Zhongguo di er lishi dang'an guan 中国第二历史档案馆, eds., Minguo shiqi Xizang ji Zangqu jingji kaifa jianshe dang'an xuanbian 民国时期西藏及藏区经济开发建设档案选编, (Beijing: Zhongguo Zangxue chubanshe, 2005), 413.

${ }^{84}$ A. Doak Barnett, China on the Eve of Communist Takeover (New York: Frederick A. Praeger, 1963), 227.

${ }^{85}$ Archibald John Little, Mount Omi and Beyond: A Record of Travel on the Thibetan Border (W. Heinemann, 1901), 210; Samuel Pollard, In Unknown China, 114; Theodore Roosevelt and Kermit Roosevelt, Trailing the Giant Panda (New York Charles Scribner's Sons, 1929), 240.

${ }^{86}$ Alexander Hosie, Three Years in Western China, 200-01.

${ }^{87}$ Zhou Taixuan 周太玄. "Xikang shangye gaikuang 西康商业概况," (1947), in JKDZ, 2. 
merchants were still selling tea from Sichuan in the Tibetan lands at the end of the Republican period; whether the trade suffered because of new competition or any other factor is a question for another study. In any case, other goods rose in importance to take the place of wax and any decline in the tea trade.

Many writers mentioned the enormous mark-ups on the price of goods going in both directions. They often interpreted this as a sign of unscrupulousness: “the Han merchants are sly and devious (jiaohua 狡猾). They pay very low prices for the barbarian produce but price their own goods at several times their real value." 88 Without taking into consideration the formidable transport costs, such comments seem somewhat unfair. Nevertheless, the evidence suggests that it was possible to become very rich through frontier trade. ${ }^{89}$ The earnings of the men who actually dug the medicines, hunted the musk-deer and cut the wood for coffins are also reported to have been relatively high. ${ }^{90}$

The trade created a large number of labouring jobs and a demand for agricultural produce. In 1911, W.N. Fergusson reported that in the busy season around 400 coolies per day arrived in Dartsedo carrying tea from Ya'an. ${ }^{91}$ In 1932, Stevenson travelled the same route, which was then still host to "an endless chain of human carriers from the lowlands of China."92 In 1939, Peter Goullart found it "filled with peasants, both men and women, carrying all kinds of things for the barren highlands." 93 Tough though it was, carrying goods through mountainous peripheral country could be relatively well paid work. The evidence from foreign travelers in Sichuan indicates that for strong porters who could carry large loads, wages were higher than those earned in labouring jobs in the Sichuan basin.

\footnotetext{
${ }^{88}$ Chen Zhongsheng, Xi xing yan yi ji, 7.

${ }^{89}$ See for example, Ren’s biographies of migrants: Ren Naiqiang, Xikang tujing: minsu pian, 256-78.

${ }^{90} \mathrm{Gu}$ Xueqiu, "Xikang sheng yaocai diaocha baogaoshu," 410.

${ }^{91}$ Fergusson, Adventure, Sport and Travel on the Tibetan Steppes, 226.

92 Stevenson, "Notes on the Human Geography of the Chinese-Tibetan Borderland," 616.

${ }^{93}$ Goullart, Princes of the Black Bone, 10.
} 
In 1877, W. J. Gill recorded that porters earned an average of 3.15 taels for carrying tea between Yazhou and Dartsedo, a trip which took 20 days with a full load. ${ }^{94}$ This was roughly 220 copper cash per day. ${ }^{95}$ Travelling in the 1890s, Archibald Little observed that the Yazhou-Dartsedo trek netted between 200 and 300 cash per day at this time as well. ${ }^{96}$ The rate remained roughly stable in the 1910s: Earnest Wilson reported a figure of 200 cash per day for the outward journey. ${ }^{97}$ Demand for transport was much higher going from east to west than in the other direction because frontier produce (gold, medicine and musk) was easier to transport than the bulky tea packages that went west. This meant that the return journey was generally unpaid, but without any goods, porters could make the journey in only a quarter of the time of the outward journey. ${ }^{98}$ Thus 220 cash per day on the outward journey meant overall daily earnings for the round trip were around 175 copper cash per day.

These rates are much better than those of unskilled workers at the salt wells in Ziliujing 自流井 (in Zigong 自贡) in the late nineteenth century, who got between 500 and 1,500 copper cash per month. ${ }^{99}$ Skilled workers

${ }^{94}$ Gill states that porters earned 1.8 taels for 6 "pau" (i.e. bao 包), and that the average porter carried between 10 and 11 pau. W. J. Gill, "Travels in Western China and on the Eastern Borders of Tibet," Journal of the Royal Geographical Society of London 28 (1878): 85.

${ }^{95}$ The rate of conversion for silver taels into copper cash varied by place and time, and Gill did not record the rates for the times and places he visited. Hosie reported that there were 1,200 cash to the tael in southern Sichuan, 1,580 in one place in Yunnan, and 1,480 in Chongqing. I have simply used the median of 1,200 and 1,580, so it is an imprecise conversion but the result is not likely to be wrong by a large margin. Hosie, Three Years in Western China, 15.

${ }^{96}$ Little, Mount Omi and Beyond, 216.

${ }^{97}$ Wilson states that the porters were paid 400 cash per "pao" (bao) and that the average load was 10 bao. He also gives 20 days as the journey time between the Yazhou and Dartsedo. Ernest Henry Wilson, A Naturalist in Western China with Vasculum, Camera, and Gun: being some Account of Eleven Years' Travel, Exploration, and Observation in the more Remote Parts of the Flowery Kingdom (London: Methuen \& Co. Ltd., 1913), 95.

${ }^{98}$ I have assumed that the unburdened return journey between Dartstendo and Yazhou could be made in about five days, as the porters that Hosie met required only two days for an unburdened journey that took ten days fully laden.

${ }^{99}$ Madeleine Zelin, The Merchants of Zigong: Industrial Entrepreneurship in Early Modern China (New York: Columbia University Press, 2005), 125. Zelin's figures are in strings of copper cash. I have assumed that there were 1,000 copper cash per string (frequently there were somewhat less, but this does not affect our estimation of monthly wages very much). Zelin's figures are supported by Hosie, who noted that the average 
got between 2,000 and 4,000 copper cash per month, so even they earned less than a porter who made 175 cash per day. ${ }^{100} 1910$ reports from Nanxi 南溪 in the south of the Sichuan basin recorded daily wages ranging from 60 cash, for wood, stone or earth workers (tu-mu-shi gong 土木石工), to 120 cash for chefs. ${ }^{101}$ Some of these workers will have received food on the job, though it is difficult to know whether this covered all their requirements, and how much the porters had to spend on food per day. ${ }^{102}$ Food price data for the highlands from this era is patchy and often given in currencies that need to be converted at uncertain rates to get prices in copper cash, so real-wage comparisons with workers in the Sichuan basin is difficult. A very rough estimate would be a daily food expenditure in Dartsedo of about 37 copper cash, falling to around half this around Ya'an. ${ }^{103}$

The descriptive evidence reinforces the view that porters were better off than the unskilled saltyard workers at least. Ernest Wilson wrote of the porters that "the pay is really good for the country, and it is this extra remuneration that tempts so many to engage in this work."104 Hosie wrote that porters who carried salt through the highlands between Sichuan and Guizhou (who were paid up to 150 copper cash per day, less than those in the western highlands) "are more or less happy at the end of each day's weary toil." 105 By contrast, he felt that the workers at the salt well "presented a very worn and unhealthy appearance, and, to judge from the

wage at the salt wells was between 1,200 and 1,500 copper cash. Hosie, Three Years in Western China, 81.

${ }^{100}$ Zelin, The Merchants of Zigong, 125.

${ }^{101}$ Li Zhuxi 李竹溪, Zeng Dejiu 曾德久, and Huang Weihu 黄为虎, eds., Jindai Sichuan wujia shiliao 近代四川物价史料 (Chengdu: Sichuan kexue jishu chubanshe,1986), 87.

102 Ibid., 127.

${ }^{103}$ Porters should have needed to eat 3 shi of barley, or 1.5 of the larger guan 官 shi per year. One source puts the cost of a guan shi of barley in Kham at 42 Tibetan yuan or about 18.9 dayang yuan in 1915 (JKDZ, 85-86). This should have been about 13.4 taels of silver, or 13,400 wen. Divided by 365 days this is 36.7 wen per day.

${ }^{104}$ Wilson, A Naturalist in Western China, 95. It is a little unclear whether by "the country" Wilson means China, the countryside or the region he was travelling in.

${ }^{105}$ Hosie, Three Years in Western China, 21. 
alarming number of beggars in the town, life at the wells must be very trying and short." ${ }^{106}$ And while Hosie pitied the poorest at the saltyard, in general the salt workers were well off compared to those in other professions. Madeline Zelin argues that the skilled salt workers, whose wages the porters matched or bettered, "did very well indeed” in the late Qing. ${ }^{107}$

There is less evidence regarding wages in other occupations in the late Qing Sichuan frontiers. Zhao Erfeng ordered that migrant craftsmen "are not permitted to raise their prices"; presumably because he felt that the prices charged by some craftsmen were already quite high. ${ }^{108}$

Wages remained high in the Republican period. Ren Naiqiang complained about the prices charged by barbers in Dajianlu:

I felt the man's skill was very poor, and gave him two thousand wen, equal to 2 jiao of silver. The man felt it was too little, and when I asked for him again he did not return. Another man came, and when he was finished we haggled over the price. I gave him three thousand wen, but still he looked unsatisfied when he left. [...] Someone told me: “[...] officials with class (daguan 達官) and big merchants all give one yuan. Even the barbarians who use wula to get here give half a yuan.”109

Ren went on to describe several frontier barbers who earned high wages despite their limited skill, including one who was employed by the magistrate of Kanze on a wage of 30 yuan per month. ${ }^{110}$ Arriving in Kangding from Shanghai in 1937, Peter Goullart wrote:

[It was] not easy to hire a servant because Chinese did not want to work as servants at comparatively small wages and preferred either to do small business by going down to the warm valleys for produce or to pan for gold in the highlands, or as a last resort to become tea carriers.

\footnotetext{
${ }^{106}$ Ibid., 81.

${ }^{107}$ Zelin, The Merchants of Zigong, 127.

${ }^{108}$ Quoted in Chen Yishi 陈一石, "Cong Qing mo Chuan-Dian bianwu dang'an kan Zhao Erfeng de zhi Kang zhengji 从清末川滇边务档案看赵尔丰的治康政绩," Jindai shi yanjiu 近代史研究, no. 2 (1985): 257.

${ }^{109}$ Ren Naiqiang, Xikang tujing: minsu pian, 271-72.

${ }^{110}$ Ibid., 272.
} 
Tibetans, too, had other interests more lucrative than menial employment. $^{111}$

Goullart was not alone in complaining about the difficulty of finding workers. Many government reports also made the same complaint. A 1938 report from Kongyu in Kangding County noted that a shortage of labour was one of the barriers to the greater exploitation of the region's minerals. ${ }^{112}$ Of course, the normal rules of supply and demand probably applied here: had the government been willing (or able) to pay workers more than they could have earned as tea carriers, there is no reason to think they would not have come.

Most workers in Kham earned much less than the barber of Kanze. At the beginning of the 1930s, Ren Naiqiang recorded that carpenters made around half to three quarters of a yuan per day, or .2 taels of silver if the employer provided food and lodgings. ${ }^{113}$ In 1931, average carpenters in Chengdu only earned six yuan plus food per month. ${ }^{114}$ Ren estimated that gathering firewood around Kangding netted around a third of yuan per day ${ }^{115}$ Even this, therefore, earned about as much as the average monthly wage in Chengdu, around 11 yuan in 1931. ${ }^{116}$

From the second half of the 1930s there is better and more standardized price data for comparisons of real wages in the highlands with those in the basin. Table one below shows 1938 grain prices in Chengdu, Ya'an and Dartsedo, as well as wages for rickshaw pullers in Chengdu and muleteers working between Ya'an and Dartsedo. I have chosen muleteers as a proxy for porters about whom there is less information in this period. In

\footnotetext{
${ }^{111}$ Goullart, Princes of the Black Bone, 15.

${ }^{112}$ Ren Hanguang 任漢光, "Kongyu Kaochaji 孔玉考察記 " Kangdao yuekan 1, no. 1 (1938). Reprinted in Zhao Xinyu and Qin Heping, eds., Kangqu Zangzu shehui lishi diaocha ziliao jiyao, 296.

${ }^{113}$ Ren Naiqiang, Xikang tujing: minsu pian, 251.

${ }^{114}$ Li Zhuxi 李竹溪 and Liu Fangjian 刘方健, eds., Lidai Sichuan wujia shiliao 历代四川 物价史料 (Chengdu: Xinan caijing daxue chubanshe,1989), 323.

${ }^{115}$ Ren Naiqiang, Xikang tujing: minsu pian, 263.

${ }^{116}$ Zeng Chongbi, "Cause Analysis of Meager Salaries of Sichuan Primary School Teachers in the 1930s," Frontiers of History in China 1, no. 4 (2006): 618.
} 
comparable regions porters and muleteers seem to have earned about the same. ${ }^{117}$ With a mule, one could make the Yazhou-Dartsedo trip fully laden in about half the time, but mules required an investment of around 100 yuan in the late 1930s, and had to be provided with fodder. ${ }^{118}$ Muleteer earnings have been estimated using the following data and sources: One 1938 report stated that it cost 1.5 yuan per day to hire a mule or horse between Yaan and Dartsedo. ${ }^{119}$ A fully laden mule could make the Yazhou to Dartsedo journey in nine days, while the unburdened return journey took only five days. ${ }^{120}$ Thus earnings over the whole trip would have been around .96 yuan per day. Fodder and accommodation was provided by inns that, in 1939, typically charged between .15 and .2 yuan per mule per night and up to .3 or .4 around Kangding where grain was expensive (and for this reason most muleteers preferred not to spend nights in Kangding). ${ }^{121}$ Due to wartime inflation, food prices in Kangding in 1939 were on average 60 percent higher than the same month of the previous year. ${ }^{122}$ Therefore, it would be reasonable to assume average fodder expenses of around .12 yuan in 1938, making overall daily earnings that year around .88 yuan, and monthly earnings around 26.4 yuan.

\footnotetext{
${ }^{117}$ Ch'en, The Highlanders of Central China, 8.

${ }^{118}$ Ren Naiqiang, "Luding kaocha ji," 114.

${ }^{119}$ Zhang Zhiyuan 张志遠, "Xikang keyi kenzhi ma 西康可以墾殖嗎?," Jianshe zhouxun 建設周迅 6, no. 18-19 (1938): 58-62. In 1939 Gu Xueqiu reported that it cost 2 yuan per stage (day) to hire a horse or mule, and 1 yuan for a slower yak (used west of Kangding). Ren Naiqiang, also writing in 1939 reported that to have goods transported between Ya'an and Kangding cost 18 yuan per 100 jin, and took nine days with fully laden mules, which makes the two rates the same for a mule that could carry 100 jin. Given the high inflation, these figures are congruent with and confirm the 1938 price. Gu Xueqiu, "Xikang sheng yaocai diaocha baogaoshu," 412; Ren Naiqiang, "Luding kaocha ji," 11415. In 1939, going from Xichang to Fulin (in Hanyuan) took eight days and cost 12 yuan per $100 \mathrm{jin}$, a rate that makes this journey 25 percent cheaper per day than the Ya'an to Kangding journey. However, food costs were much lower in Ningshu (see below); CKSB, 176.

${ }^{120}$ Ren Naiqiang, "Luding kaocha ji," 114-15.

${ }^{121}$ Ibid.

122 "Zhan shi Kangding shi wu jia dongtai 戰時康定物價動態," Xikang jingji jikan 1, no. 5-6 合刊 (1943): 50-51.
} 


\begin{tabular}{|c|c|}
\hline Cost of rice in Chengdu (yuan / shi dou 市斗). ${ }^{123}$ & 1.11 \\
\hline Cost of rice in Yaan (yuan / shi dou). ${ }^{124}$ & 0.94 \\
\hline Cost of barley in Dartsedo (yuan / shi dou). ${ }^{125}$ & 1.96 \\
\hline $\begin{array}{lcccc}\begin{array}{l}\text { Chengdu } \\
\text { (yuan). }{ }^{126}\end{array} & \text { richshaw pullers' average monthly } & \text { wage } \\
\end{array}$ & 17.5 \\
\hline $\begin{array}{l}\text { Dou of rice purchased in Chengdu with rickshaw pullers' } \\
\text { average monthly wage. }\end{array}$ & 15.9 \\
\hline $\begin{array}{l}\text { Estimated monthly earnings of muleteers (yuan) working } \\
\text { between Yaan and Dartsedo. }\end{array}$ & 26.4 \\
\hline $\begin{array}{l}\text { Dou of grain purchased with estimated monthly muleteer } \\
\text { income, using median of Dartsedo and Yaan price (1.45 } \\
\text { yuan per } d o u) \text {. }\end{array}$ & 18.2 \\
\hline
\end{tabular}

Table one: Comparison of real wages of Chengdu rickshaw pullers and muleteers between Ya'an and Dartsedo in 1938

Table one indicates that porters/muleteers earned about 15 percent more, in real terms than rickshaw pullers in Chengdu. It was a relatively small difference, and it seems unlikely that this alone could have drawn a man from the Sichuan basin to the highlands. Yet for an unskilled but physically strong man from around Ya'an, carrying goods west, which also offered the possibility of stints on gold-fields or gathering medicine, was probably a more likely option than going to Chengdu to haul rickshaws.

\footnotetext{
${ }^{123}$ Li Zhuxi and Liu Fangjian, eds., Lidai Sichuan wujia shiliao, 385.

${ }^{124}$ Ibid., 386.

${ }^{125}$ This is an estimate using price indexes in Xikang Economy Quarterly and October 1940 prices as given by the Agriculture Institute. The October 1940 highland barley price was 87 yuan per $100 \mathrm{jin}$. The food price index for October 1940 was 771.05 (100 being the average of the first six months in 1937). Using the inflation index data for each month in 1938 to calculate monthly barley prices in that year gives an overall average for the whole of 1938 of 13.1 yuan per 100 jin, or 19.6 yuan per shi weighing 150 jin. Xikang sheng nongye gaijin suo 西康省農業改進所, "Kangding chengxiang wujia diaocha 康定城廂 物價調查," 1940, (SCDAG, QZH:249, AJH:33); Xikang jingji jikan 西康經濟季刊, 1942, no.5-6 combined issue(合刊), 50. Being lighter than rice, barley is less nourishing per unit of volume. I have not adjusted the data to take account of this because, firstly, muleteers could probably have eaten rice most of the way, and secondly, using the median of Dartsedo and Ya'an probably over-estimates their food costs. Prices do not appear to have risen in a linear fashion.

${ }^{126}$ Li Zhuxi and Liu Fangjian, eds., Lidai Sichuan wujia shiliao, 396.
} 
Trade also created a demand for agricultural produce. Passing through Kham in 1926, Paul Stevenson noted that there were two types of Chinese settlements in that region:

The more important is represented by the Chinese settlements along the great highway that for centuries has provided the link between China and Tibet. The size of the settlements and the distance between them are determined largely by the requirements of the traffic passing over the road [...] The second type of Chinese settlement in the region is found in the few agricultural communities that have managed to establish themselves on the occasional alluvial cones large enough to permit irrigated cultivation. The encouragement of agricultural conquest has been a definite government policy in recent years, and the old imperial title of "Warden of the Marches" is now changed to that of "Commissioner of Cultivation." The Chinese agriculturists that have taken root in this area, however, are few and far between. ${ }^{127}$

Ren Naiqiang gave several examples of the former kind of settlement, which profited by growing food supplies for the merchants and the communities that developed around trade routes and resource extraction industries. In 1929, Ren wrote:

In the late Qing dynasty, many Han people came to Dartsedo. [...] There were not enough vegetables, so peasants arrived to cultivate the surrounding hillsides. They made great profits, and the cultivated area spread out for ten li around the town. ${ }^{128}$

Other writers also noted the connection between the arrival of goldminers in a certain place and the ensuing cultivation of land around the mines. ${ }^{129}$ Elsewhere, Ren even referred to such farmers as "market gardeners” (ying caipuye zhe 營菜圃業者) rather than as peasants (nongmin 農民) or “cultivators” (kenfu 墾夫, kenmin, 墾民). ${ }^{130}$ Ren’s accounts of pretwentieth century Han settlements around garrisons in Kham also

\footnotetext{
${ }^{127}$ Stevenson, "Notes on the Human Geography of the Chinese-Tibetan Borderland," 601.

${ }^{128}$ Ren Naiqiang, "Kangding xian shicha baogao," 259.

${ }^{129}$ Yin Ziwen 尹子文, "Luhuo gaikuang 炉霍概况," Kangdao yuekan 2, no. 4 (1945): 133.

${ }^{130}$ Ren Naiqiang, Xikang tujing: minsu pian, 260.
} 
demonstrate the same trend. ${ }^{131}$

There was not a great deal of unused arable land in Kham; how much there was in Ningshu is more of a mystery because no surveys were carried out there. However, the key limit on the agricultural sector and the "great profits" that could be made in it was not the overall availability of land, but by the limited availability of land near markets. The enormous costs of transport in the highlands quickly eroded the high returns from farming so that as farmers moved away from major markets, returns ceased to be competitive with the wages in unskilled labour jobs. This meant that land around major markets like Dartsedo was farmed intensively and very profitably, but land further away was not.

Tables two and three below give rough estimates for average yield, labour requirements and market value of yield for barley in Dartsedo and rice in four Ningshu county towns. A tenant-farmer near Dartsedo who kept ten percent of the yield back for seed and paid 30 percent of the yield as rent would be able to take an average of .72 of a shi of barley per mu to market. ${ }^{132}$ The .72 of a shi would have sold at Dartsedo for 22.68 yuan. In 1939, transporting .72 of a shi of grain by mule cost around 2 yuan per day. ${ }^{133}$ In addition to these costs, there was fertilizer, and other marketing expenses, like market fees and storage. I have not encountered any evidence that permits a precise estimate, but it would be reasonable to deduct a few yuan for these expenses. ${ }^{134}$ Let us say final profits were 18 yuan per $m u$. If each $m u$ required around nine days of labour - the same as what Buck's data indicates was necessary for wheat-and one day per mu for marketing,

\footnotetext{
${ }^{131}$ See Ren Naiqiang, "Luding kaocha ji."

${ }^{132}$ Reported rents paid by Han and mixed farmers in Kang vary from around twelve percent of output to fifty percent Ren Naiqiang, Xikang tujing: minsu pian, 262-63. One 1944 survey indicated that 81 percent of farmers in Kangding and 42 percent in Luding were tenant-farmers (diannong 佃農), with only 1.65 percent and 32.17 percent respectively being classified as owner-farmers (zigengnong 自耕農) as opposed to semi-owner farmers (ban-zizongnong 半自耕農). Wu Wenhui and Zhu Jianhua, "Xikang tudi wenti," 21.

${ }^{133}$ Gu Xueqiu, "Xikang sheng yaocai diaocha baogaoshu," 412.

${ }^{134}$ One of the industrial projects in Kangding begun after 1939 was a fertilizer plant, which perhaps indicates that — despite the large number of animals — there was a shortage of fertilizer in the region.
} 
returns to labour were pretty similar to muleteering. ${ }^{135}$ Therefore, under such conditions, renting and farming land around Kangding was also more lucrative than the average waged-labour job in Chengdu.

\begin{tabular}{|l|l|l|l|}
\hline & \multicolumn{2}{|l|}{ Crop } \\
\hline & Rice & Barley & Wheat \\
\hline $\begin{array}{l}\text { Estimated days of labour } \\
\text { per } m u .\end{array}$ & $10.3^{136}$ & $8.8^{137}$ & \\
\hline $\begin{array}{l}\text { Possible average yield per } \\
\text { mu (market shi 石) }\end{array}$ & $2.95^{138}$ & $1.20^{139}$ & \\
\hline
\end{tabular}

Table two: Estimates of labour requirements and yield for barley, wheat and rice

${ }^{135}$ By 1939, the cost of hiring a mule had increased (see above) but considering the cost of fodder, farming was still more profitable. The amount of labour necessary for a $m u$ of wheat is controversial. The nineteenth century Pumao nongzi 浦泖農咨 suggests that winter wheat only needed three days of labour per $m u$ in southern Jiangsu. Bozhong $\mathrm{Li}$, "Farm Productivity in Jiangnan, 1620-1850," in Living Standards in the Past: New Perspectives on Well-Being in Asia and Europe, ed. Robert C. Allen, Tommy Bengtsson, and Martin Dribe (Oxford: Oxford University Press, 2005), 64. Republican period Japanese research gave a figure of 7.8 days per $m u$ for the same crop in Hebei, Philip C. C. Huang, The Peasant Economy and Social Change in North China (Stanford: Stanford University Press, 1985), 110. If labour requirements to achieve a yield of 1.2 shi of barley per average $m u$ in the highlands were actually less than this, then obviously farming was even more profitable.

${ }^{136}$ J. Lossing Buck, An Agricultural Survey of Sichuan Province, China (Chungking: The Farmers Bank of China, 1943), 50-54.

${ }^{137}$ Ibid.

${ }^{138}$ Ibid., 4. In this instance Buck's Sichuan data is reasonably compatible with $\mathrm{Li}$ Bozhong's study of southern Jiangsu in the nineteenth century, which estimates average rice yields per $\mathrm{mu}$ at $2.5 \mathrm{shi}$; Li, "Farm Productivity in Jiangnan, 1620-1850," 62.

${ }^{139}$ Current Chinese studies of pre-1950s Tibetan agriculture also indicate average highland barley and wheat yields per $m u$ of around $83 \mathrm{~kg}--1240.5 \mathrm{~kg}$ per hectare, assuming that 1 hectare equals $15 \mathrm{mu}, 82.7 \mathrm{~kg}$ per $\mathrm{mu}$, (Wu Shaohong and Yang Qinye, "Land-Use and Agricultural Development," in Mountain Geoecology and Sustainable Development of the Tibetan Plateau, ed. Zheng Du, Zhang Qingsong, and Wu Shaohong (Dordrecht: Kluwer Academic Publishers, 2000), 182). According to Perkins' figures, the Republican period national average per $m u$ yield of barley was around $75 \mathrm{~kg}$ Perkins, Agricultural Development in China. I have used Perkins' figure, and assumed that 1 shi of barley weighs about $62 \mathrm{~kg}$ (calculated according to data from University of Missouri http://extension.missouri.edu/publications/DisplayPub.aspx?P=G4020 (accessed 18/07/10). This source gives barley as 48 pounds per bushel. 1 bushel $=35.24$ litres; 1 pound $=.454 \mathrm{~kg} ; 1 \mathrm{shi}=100$ litres). 


\begin{tabular}{|l|l|l|}
\hline County & Rice & Barley \\
\hline Kangding & & $31.5^{140}$ \\
\hline Hanyuan & $8.3^{141}$ & \\
\hline Yuesui & $24.6^{142}$ & \\
\hline Mianning & $20.8^{143}$ & \\
\hline Xichang & $12.9^{144}$ & \\
\hline
\end{tabular}

Table Three: Market price of grain in yuan per shi in various Xikang counties in June 1939

However, two yuan per day transport costs would have quickly reduced the profitability of farming the further one moved from Dartsedo. Farmers who lived more than one day from the town also faced greater marketing expenses as they needed to pay accommodation expenses. Beyond this, farming could only have been more profitable than muleteering if farmers owned their own land and paid land taxes of less than the 30 percent that we proposed as a typical rent above, or if the land they farmed was exceptionally productive. The advantage of being within a day's journey from Dartsedo is clearly illustrated by the intensity of farming around the town. In 1929, Ren Naiqiang reported that most of the arable land in Kangding and Luding had already been brought under cultivation, such that

\footnotetext{
${ }^{140}$ This is an estimate using price indexes in Xikang Economy Quarterly and October 1940 prices as given by the Agriculture Institute (see note 123 above). The food price index for October 1940 was 771.05; June 1939 was 185.9. October 1940 highland barley price was 87 yuan per $100 \mathrm{jin}$. Therefore, the June 1939 price should have been 20.97 yuan per 100 jin. If 150 jin equals 1 shi, the per shi price would be 31.46 yuan. This roughly tallies with a report in Xikang sheng zhengfu gongbao that said corn flour cost 25.33 yuan per 100 jin in August 1939. Xikang sheng zhengfu gongbao 西康省政府公報, no. 9 (1939), unpaginated tables.

${ }^{141}$ Prices in this source are given by weight in jin. I have converted them into shi on the grounds that 1 shi equals $83 \mathrm{~kg}$ (John Shepherd, Statecraft and Political Economy on the Taiwan Frontier 1600-1800, (Stanford: Stanford University Press, 1993), 158) and 1 kg equals two jin (CKSB, 203).

${ }^{142}$ CKSB, 203.

${ }^{143}$ Ibid.

${ }^{144}$ Ibid.
} 
“if the farmers' sons and younger brothers come, there will be no space for them.” ${ }^{145}$ Photographs of Dartsedo from this time also show that even very steep hillsides around the town were cultivated, leaving almost no land untilled.

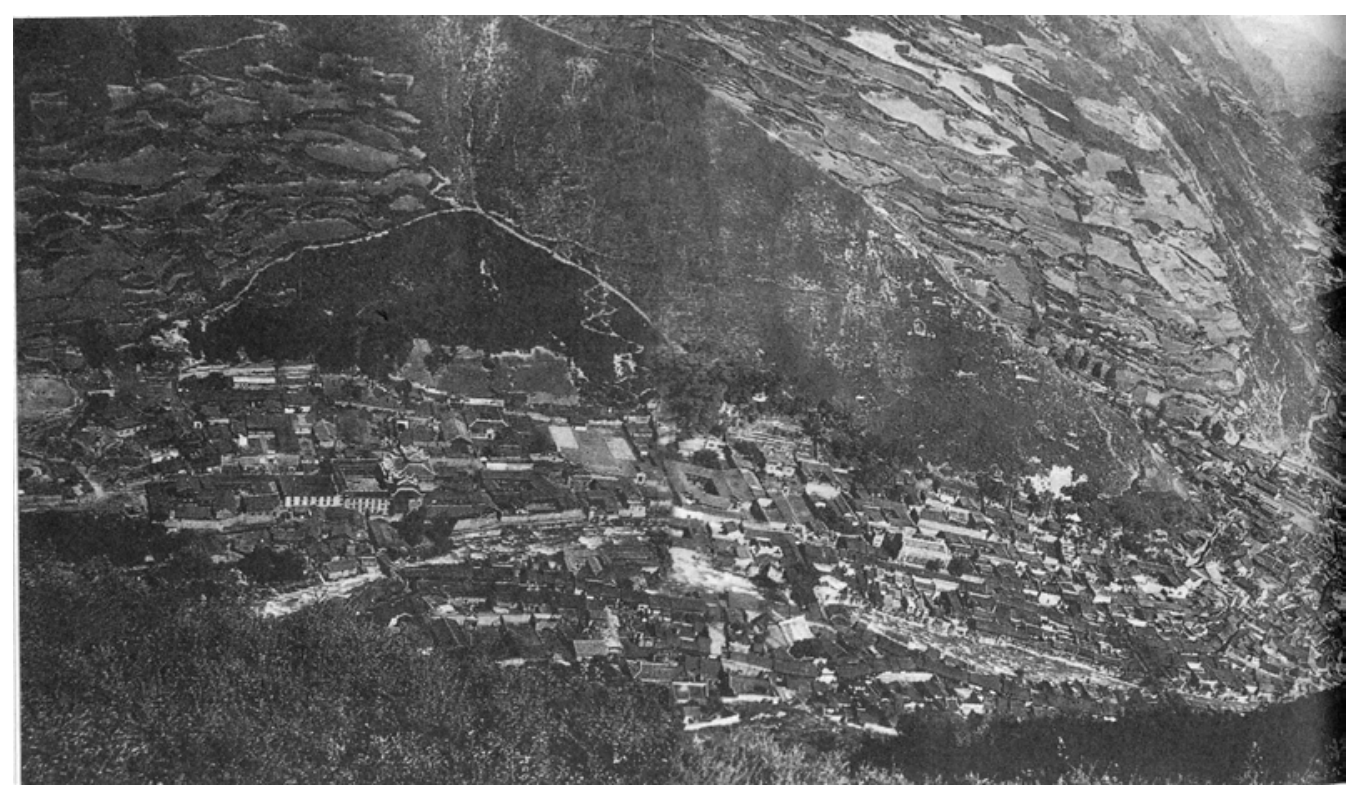

Dartsedo in 1939. Photo by Sun Mingjing 孫明經 $(1911-1992) .{ }^{146}$

Doing the same calculation for a $m u$ of rice in Xichang gives almost exactly the same return as Dartsedo. In Yuesui and Mianning, returns from rice land were much better still because of the higher price in those counties. However, only some of the farmers in these locations had access to land suitable for growing rice. The rest grew barley and wheat, which, with their much lower yields per mu and lower price per shi, were a much less attractive proposition. It was probably for this reason that the SichuanXikang Survey Report noted that in a village in Yuexi "all of the ablebodied men have left to work as porters.” ${ }^{147}$ Of course, as we saw in chapter one, from the mid 1930s a lot of farmers in Ningshu grew opium. It is very difficult to determine, however, what kind of returns farmers themselves got for the opium crop.

\footnotetext{
${ }^{145}$ Ren Naiqiang, "Luding xian shicha bagao," Bianzheng, no. 2 (1929), in Zhao Xinyu and Qin Heping, eds., Kangqu Zangzu shehui lishi diaocha ziliao jiyao, 332.

${ }^{146}$ Zhang Ming 张鸣, and Sun Mingjing 孙明经, 1939 nian: zoujin Xikang 1939 年: 走进 西康, (Jinan: Shandong huabao chubanshe, 2003), 60.

${ }^{147}$ CKSB, 198.
} 
In sum, farming in the frontier was also a potentially lucrative occupation, but only where farmers had land next to a major market. Therefore, the amount of genuinely unused arable land there was in the frontier is irrelevant to an explanation of why this territory did not become a booming agricultural colony like Manchuria. The high cost of transportation, and the existence of well-paid labour jobs explain why the Zhao Erfeng vision of relatively large-scale agricultural settlement did not materialize. As Ren Naiqiang commented many new settlers in the late imperial period abandoned their new lands and went into trade. ${ }^{148}$ The region's lucrative resource extraction industries, and the highly profitably trade that passed through it, meant that labour was in high demand. This pulled wages up to a level where many outsiders commented on how expensive they were, which meant that it was not worthwhile for households to strike off into the wilderness to seek out new land to farm when it was likely they would get better returns working as a porter.

Ideological Factors in Migration.

Higher wages for unskilled work than could be had in the Sichuan basin was one factor that drew migrants to the frontier highlands in the Republican period. In some cases, ideology was important too. From the second half of the nineteenth century, increasing migration to the borderlands became a standard article on the reformist program of steps necessary to modernize China and defend the nation against foreign aggression. Major reform figures like Kang Youwei 康有為 (1858-1927) and Liang Qichao 梁啟超 (1873-1929) championed the cause of Han settlement in the borderlands. In the last decade of the Qing, settler-ism had a significant impact on government policy in the frontier and resulted in very substantial support for migrants who were willing to become farmers in Kham, though the number of agricultural migrants remained small. As we saw in chapter three, the focus of state policy shifted in the Republican period from encouraging

\footnotetext{
${ }^{148}$ Ren Naiqiang, Xikang tujing: minsu pian, 255.
} 
settlement by independent farmers to establishing large state-owned agricultural enterprises. Public ownership over huang land was no longer enforced. In some places, wealthier migrants might have been attracted by this, but it probably restricted opportunities in farming for poorer migrants. As demonstrated above, where farmers were not within a day's journey from a major market, they needed low-cost access to land for farming to be profitable. It is safe to conclude that, apart from creating a small number of jobs on state farms, the Xikang provincial government's agricultural policy did not draw in many migrants.

Nevertheless, Liu Wenhui and some of his officials may have contributed towards migration through their active promotion of positive images of the highlands and the kind of life that awaited potential settlers. This is an element of Liu's administration that has been highlighted by James Leibold, who discusses a propagandistic play serialized in the journal Bianzheng gonglun. ${ }^{149}$ The play follows the story of a bold intellectualturned-pioneer who is committed to “race-state-ism” (guozu zhuyi 國族主 義) and to doing his bit for the development of the Tibetan lands and ensuring that they remain within the Chinese nation. He decides to go to the frontier and overcomes many hardships on his journey to Ba'an where he is "treated as a messiah-king by a mob of childlike Tibetans" and initiates development plans that bring more than one hundred thousand $m u$ of wasteland into cultivation. ${ }^{150}$ On this and other occasions, Liu Wenhui and his staff actively promoted positive images of the highland natives and their interactions with Han settlers. "The Kham people see their religion as a embodying a splendid culture, and they are, in general, a peaceable people (pianyu haojing 偏於好靜).” ${ }^{\prime 151}$ Ren Naiqiang wrote that according to the "laws of assimilation", the "Fan” people of Kham would be the easiest nonHan people in all of China to assimilate. ${ }^{152}$

\footnotetext{
${ }^{149}$ Leibold, Reconfiguring Chinese Nationalism, 69-70.

${ }^{150}$ Ibid., 70. (Quotes are Leibold's words)

${ }^{151}$ Liu Wenhui, "Xikang xiankuang ji Zhao Erfeng zhi Zang zhi shi de 西康現況及趙爾豐 治藏之失得," Xibei wenti jikan 西北問題季刊 2, no. 1-2 (合刊) (1936): 28.

${ }^{152}$ Ren Naiqiang, Xikang tujing: minsu pian, 219-22.
} 
It is difficult to judge the impact of this kind of discourse. There certainly were some negative stereotypes to counter. One journal article lamented in 1935 that after fall of the Qing:

The Barbarians began to talk of cleansing the land of the Han and many settlers (kenfu 墾夫) were killed. To this day, when the people of the Interior talk of going to the frontier to cultivate the earth, they see it as an ill fated (bu xiang 不祥) matter. ${ }^{153}$

Staged performances showing migrants facing a more positive reception may have gone some way toward balancing such talk.

Settler-ism did motivate at least a few migration endeavours. Chapters one and five introduced the ill-fated Bathang Cultivation Company, established by patriotic intellectuals in the 1900s. Though their efforts at Bathang ended in disaster they did not abandon the great mission to settle the borderlands with diligent farmers. The Company chose a new site on the border of Yi territory in Leshan; much closer to home but still 'frontier' enough to have to make the agreements with the Yi chieftains detailed in the previous chapter. Rechristened the Leshan and Pingshan Cultivation Society (kenwu gongshe 墾務公社), Peng Jinmen and his associates battled on through the Republican period. As they did so, their focus shifted toward forestry and away from grain-growing. Its eventual accomplishments were modest and very different from what Peng had envisaged in 1906. Nevertheless, it demonstrates that the widely held ideological commitment to settling the frontier did result in some actual settlement.

\section{Conclusion}

Migration to the highlands west and southwest of the Sichuan basin did not rival the magnitude of the flow of people into Manchuria, where a booming settler population utterly transformed the demographic and ecological landscape of the region. Nevertheless, the Han population around Kangding,

${ }^{153}$ ZYDZ, "Diaocha ziliao," Chuanbian jikan 1, no. 1 (1935): 171. 
Luding, Yuesui and Hanyuan doubled, or in some cases more than doubled, over the first half of the twentieth century. Other places also saw significant increases, but a lack of reliable population data prevents estimates of their magnitude. This growth occurred at a time of demographic stagnation in the region that the migrants came from. Moreover, it contrasts sharply with the population decline that took place in the highlands east of Sichuan. In many instances, the establishment and survival of Han local governments was not absolutely necessary for migration to take place, but it almost certainly helped. Gold, valuable medicines and musk drew many migrants. Arrivals in the highlands probably dreamt more of become rich through trade or gold mining than they did of toiling under the weight of packages of tea on the road between Yaan and Dartsedo. I have concentrated on the returns to the latter form of labour, because doing so demonstrates that even unlucky miners who failed to find anything at all, or who were robbed, could still earn better money in unskilled labour than was possible in Chengdu. This chapter has also shown that farming could be highly lucrative as well, providing that one had land within a day or so of a major market. Beyond this, farming was not competitive with jobs such as carrying tea, which explains why there was not more agricultural settlement in the highlands. In some cases there was probably another motivation besides the high wages of the region: the chance to play one's heroic part in the development of the nation. The hopes and anxieties of this grand pioneering endeavour, and those of the other twentieth century missions to transform the frontier, are the subject of the final chapter. 


\section{Chapter Seven: Visions of Transformation: Culture and Politics on the Frontier, 1905-2010}

This thesis has been about attempts to transform the frontier, and this final chapter examines the way that the nature and agents of change have been conceptualized throughout the twentieth century. The first section of this chapter continues the theme of the previous chapter, and examines representations of Han settlement and the migrants themselves. Leaders and intellectuals often saw the settlement by a generation of tough and righteous pioneers as critical to the mission of transforming the frontier. However, there was also considerable anxiety about the quality of the actual migrants and the nature of the change that they brought.

The subsequent discussion of late Qing and Republican period conceptualizations of change is loosely based on the trio of changes to frontier society promised by Liu Wenhui’s “Three Transformations Policy (san hua zhengce 三化政策). Liu called it a “policy”, but it was more a loose sketching of three types of change that he thought needed to happen, rather than a series of practical measures. In this respect it was similar to, and the formulation was probably inspired by, Sun Yat-sen's “Three Principles of the People” (san min zhuyi 三民主義). Liu's Three Transformations were, firstly, “change through enlightened rule” (de hua 德 化) (which, as we shall see, was really two transformations in one); secondly, “assimilation” (tong hua 同化); and, thirdly, "progress” (jin hua 進化). It was certainly not only Liu who was concerned with these ideas; almost all of the transformations that have been argued as either necessary or historically significant in the twentieth century could fit under one of these broad headings. However, they could mean very different things to different people, and there has been considerable disagreement about whether all three were important and which should be prioritized. Having examined the discussion of these topics in the Republican period, this chapter concludes with a reflection on how they emerge within present day narratives of historical change. 
Han Pioneers: Agents of Civilization and Progress, or Degeneration?

As we saw in the previous chapter, Liu Wenhui promoted the idea of a political settler: an upright and competent colonist who, inspired by a sense of national mission, would work to transform the borderlands. Ren Naiqiang argued that Han settlement was "the best route to the assimilation of the Fan [Tibetans]”. ${ }^{154}$ During the Republican period, “tuobianzhe 拓邊者” (“those who push out the frontier”) entered the Chinese language as a translation of “pioneer”. ${ }^{155}$ Zhu Zengyun, an early Republican period magistrate of Dawu, referred to the "philosopher” Daniel Defoe, and suggested that lessons from Robinson Crusoe could be drawn for his own world building exercise in Dawu. $^{156}$

However, as the previous chapter also demonstrated, unless you were lucky enough have staked out land next to Dartsedo or another key market town, farming was less profitable than pursuits such as carrying goods for merchants or medicine-gathering, which were inherently mobile. Yet a large body of Chinese thought held that a settled lifestyle was the key to a peaceful and virtuous one. The Sichuan-Xikang Survey Report outlined a fanciful plan for the reform of Yi society, which emphasized that it was important for all $\mathrm{Yi}$, even if they had rebelled against the government, to own land.

If they are given some settled property (heng chanwu 恒产物 [i.e. real estate, land]), they will have settled hearts and minds (heng xin 恒心). If they have a settled hearts and minds, the relationship between us can be improved. ${ }^{157}$

As chapter two demonstrated, Zhao Erfeng's plan for migration focused strongly on the development of stable agricultural communities. He

\footnotetext{
${ }^{154}$ Ren Naiqiang, Xikang tujing: minsu pian, 231.

${ }^{155}$ Mo Dehui 莫德惠, "Ningshu zhi Yi zhi wo jian 寧屬治夷之我見," Kangdao yuekan 康 導月刊 5, no. 11-12 (合刊) (1943): 26.

${ }^{156}$ Zhu Zengyun, "Chuanbian zhengxie," 120.

${ }^{157}$ CKSB, 172.
} 
prohibited the sale of land, and attached discouraging conditions to the subletting of it. Furthermore, medicine gatherers were actually forbidden from going to certain places, due to the presumption that they would cause trouble with the locals (despite the abundant evidence that Zhao Erfeng and his armies caused much more turmoil than small bands of medicine gatherers and miners).

This was an attitude highly reminiscent of the quarantine-ism of the eighteenth century, when settlers were more likely to be called "Han evildoers” (Hanjian 漢奸), and blamed them for stirring up problems, than lionized as the agents of civilization and progress. ${ }^{158}$ Donald Sutton shows that in the early eighteenth century Guizhou, many officials blamed "all the troubles of the frontier on these [Han] illegal intruders.” 159 Consequently, from 1708 all movement across the ethnic frontier in Guizhou was forbidden except for the purposes of paying taxes or buying necessities. The punishment for violating this rule, or the one against intermarriage, was one hundred blows with heavy bamboo and penal labour.

The pioneering political settler who was the agent of twentieth century governments' development and civilizing missions did not supplant but existed alongside the trouble-making Han-evil-doers of earlier times. Chen Zhongwei described Han settlers in Xikang thus:

With the encouragement of the government, there rushed in not only a crowd of hooligans (liumang 流讯 ) and ex-convicts, but also unemployed workers and regular profit-chasers. ${ }^{160}$

The same terms-hooligans, ex-convicts and profit-chasers-were used by a 1940s General Introduction to Xikang Commerce. ${ }^{161}$ Ren Naiqiang

\footnotetext{
${ }^{158}$ See Donald S. Sutton, "Ethnicity and the Miao Frontier in the Eighteenth Century" in Empire at the Margins: Culture, Ethnicity, and Frontier in Early Modern China, eds. Pamela Kyle Crossley, Helen F. Siu, and Donald S. Sutton (Berkeley: University of California Press, 2006), 193. Also C. Patterson Giersch, "'A Motley Throng:" Social Change on Southwest China's Early Modern Frontier, 1700-1800," The Journal of Asian Studies 60, no. 1 (2001): 68.

${ }^{159}$ Sutton, "Ethnicity and the Miao Frontier in the Eighteenth Century ," 199.

${ }^{160}$ Chen Zhongwei, Xikang wenti, 89.

${ }^{161}$ Zhou Taixuan, "Xikang shangye gaikuang," in JKDZ, 221.
} 
wrote that in Dartsedo the people were "craftier by nature than in any other place." ${ }^{162}$ He complained about the brothels and opium dens and concluded that "the dregs of Han society were especially prominent (Hanren zhi duoluo zhe you duo 漢人之墮落者尤多).”163 A Daocheng official explained to Chen Zhongsheng that:

The Han who stay here mostly conduct trade or till the earth. But they are all deeply lacking in knowledge and, moreover, most of them are criminals or have undesirable social habits. The so-called Han-ization (Hanhua 漢化) that they spread among the natives, is also nothing more than the spread of vulgar attitude of marketplaces. ${ }^{164}$

Similarly, Jiang Wuji blamed Han gold-miners and traders for locals' opium addictions in Yutong. ${ }^{165}$ When the Sichuan Frontier Quarterly mentioned that the Pingshan government had begun using convict labour to cultivate the land, it informed readers that there were many prisoners there because: “Pingshan is located in the borderlands (bianchui 邊陲), and the people’s quality is inferior (minxing po lie 民性頗劣).”166

Chen Zhongwei gave a long list of the kinds of people he wanted to see settle in Xikang; a good sign that he was not entirely happy with the kinds of people who had migrated thus far. Chen stressed that only the following types of people were suitable:

1) Not lascivious, drinkers, users-of-prostitutes or gamblers.

2) Do not have mental illnesses (jingshenbing 精神病).

3) Do not have infectious diseases.

4) Accompanied by wives and families.

5) Responsible and hard working.

6) Committed to maintaining public order and the public interest.

7) Possessed of everyday abilities.

\footnotetext{
${ }^{162}$ Ren Naiqiang, "Kangding xian shicha baogao, 262.

163 Ibid.

${ }^{164}$ Chen Zhongsheng, Xi xing yan yi ji, 217.

165 Jiang Wuji 蒋五䩀, "Yutong suoying 鱼通缩影," Kangdao yuekan 1, no. 1 (1938), in Kangqu Zangzu shehui lishi diaocha ziliao jiyao, eds. Zhao Xinyu and Qin Heping, 315.

166 ZYDZ, "Diaocha ziliao," Chuanbian jikan 1, no. 1 (1935): 176.
} 
8) Have not been convicted of an offence.

9) Serious and calm in deed and word.

10) Articulate. ${ }^{167}$

11) Calm and collected.

Ren Naiqiang produced a similar list, as had Zhao Erfeng for candidates for his Tibetan language school in Chengdu. ${ }^{168}$ Chen's notion that it was important for settlers to be accompanied by their wives is interesting because it clashed with some observers' hope that the government would encourage the intermarriage of migrants with locals, a suggestion that we shall examine below.

Discourse that complained about the quality of existing migrants cannot have made those who did fit the criteria given in such lists feel particularly positive about going to the frontier. Ironically, when Ren Naiqiang came across Liu Shaoyao, a migrant who did seem to mostly live up to the profile outlined by Chen and himself, Ren's instinct was to try to take Liu back to Sichuan with him. Liu was the nephew of a Nanchong squire (xiangshen 鄉 紳), educated, married, possessed of an "honest and sincere nature” and able to speak the local Tibetan language. ${ }^{169}$ Apparently forgetting that this was precisely the type of person he had proclaimed that Xikang needed, Ren comments that he "could not see how Liu could have wandered into Nyarong”, and that he desired to lead Liu back home. ${ }^{170}$ Such was the disparity between Ren's impression of the type of people whom he usually met in the frontier and the ideal settler.

Thus there was a strong tension in Republican period discourse on frontier society. A vision of a bold pioneering settler society co-existed with a persistent fear regarding the quality of the actual migrants and the problems that they were perceived to cause.

\footnotetext{
${ }^{167}$ Chen Zhongwei, Xikang wenti, 260. With the last point (yuyan minjie 語言敏捷), Chen possibly meant the ability to learn new languages. As far as his fourth point went, the eighteenth century imperial state oscillated between allowing and prohibiting settlers to bring their wives to frontier regions. See John Robert Shepherd, Statecraft and Political Economy on the Taiwan Frontier, 1600-1800.

${ }^{168}$ For Zhao's criteria see JKDZ, 396.

${ }^{169}$ Ren Naiqiang, Xikang tujing: minsu pian, 266.

${ }^{170}$ Ibid.
} 
De hua 德化: The Case for Virtuous Rule

The critique of the Han presence in the highlands was certainly not reserved for lowly gold miners and traders. Many observers argued that the problems of the frontier were caused primarily by immoral governance. Indigenous leaders did not escape criticism, but blame was also directed mostly at Han officialdom. The Guomindang sponsored Sichuan-Xikang Survey Report wrote:

[From the late Qing dynasty on], there have been many unethical men within Han officialdom, who often used the power of their offices to cheat and prey upon the natives. Civil and military officials alike combined with the unscrupulous men outside the government to develop ways of exploiting the native people. Considering that the natives are, by nature, greedy and turbulent, and that they view wealth as the most important thing in life, one can well imagine how deep their hatred is. This is the cause of the native grievances. ${ }^{171}$

Ren Naiqiang wrote that "in the years after gaitu-guiliu, the low level officials acted autonomously, plundering the wealth of the Kangding people in order to fill their own bellies.” ${ }^{172}$ Material compiled political department (zhengzhi bu 政治部) of the Twenty Fourth Army argued that the former frontier governors behaved like foreign imperialists:

Frontier governors have never treated the people of the borderlands in a just manner. In the minds of the frontier governors, the border people are not even fully human; their position is like the black slaves of America, or the colonized people of the British Empire. ${ }^{173}$

The corollary of the belief that misrule had caused the region's troubles was the notion that the solution lay in virtuous governance. Of course, leaders who talked about ethics in government did not necessarily lead

\footnotetext{
${ }^{171}$ CKSB, 171.

172 Ren Naiqiang, "Kangding xian shicha baogao," 267.

${ }^{173}$ Guomin geming jun di ershisi jun 国民革命军第二十四军, "Chuan Kang bianwu xuanchuan jiyao 川康边务宣传辑要," in Kangqu Zangzu shehui zhenxi ziliao jiyao (shang), eds. Zhao Xinyu, Qin Heping, and Wang Chuan (Chengdu: Bashu shushe, 2006), 300 .
} 
institutions that actually behaved more ethically than those who did not. Nevertheless, the Republican period saw a profusion of discourse on the need for a moral reform of government. The first of Liu Wenhui's “Three Transformations” addressed this issue. Liu called the policy de hua 德化, a term not of his own invention that is difficult to fully convey in succinct English. De 德 means “virtue” or “morality”; hua 化 means “transform”. De hua is really a classical contraction that modern dictionaries explain as $y i$ dao xing gan hua ren 以德行感化人, “using virtue to transform people”. Virtuous example is the pedagogical tool used by the ruler to guide his subjects toward a more perfect existence. In practice, de hua suggests two transformations: firstly the transformation of the government so that it projects an example of virtue. Secondly, the transformation of the population in response to the virtuous example set by the government.

[The first transformation] is a policy of effecting change through morally enlightened rule (de hua zhengce 德化政策). It stands opposite to a policy of effecting change through coercion (weifu zhengce 威服政 策). [...] History demonstrates that even though a policy of coercion may result in temporary success, as soon as the government's head is turned, crushing failures will emerge, and all the successes will be undone. In order to thoroughly break the cycles of revenge, and lay the foundations for long-term development, I am determined to replace coercion with governance by moral example. ${ }^{174}$

De hua promised a moral reformation of government that would inspire loyalty and positive change where coercive rule had inspired only temporary obedience and desire for revenge.

However, not everybody agreed that virtuous government was really the key to solving the problems of the frontier. The supposed inevitability of the second transformation proposed by de hua seemed highly questionable to some. If the Yi did not “cherish virtue” (huai de 懷德), even the example of the most virtuous of governments would not lead to their transformation. Many took the view outlined by Liu Yuetian:

\footnotetext{
${ }^{174}$ Liu Wenhui, "Jianshe xin Xikang shi jiang 建設新西康十講,," in Kang qu Zang zu shehui zhenxi ziliao jiyao (xia), ed. Zhao Xinyu, Qin Heping, and Wang Chuan (Chengdu: Shu ba shushe, 2006), 602.
} 
The character of the Yi is like that of dogs or goats. They are capricious and do not cherish virtue, and therefore can only be ruled through fear of force (wei wei er bu huai de 畏威而不懷德). ${ }^{175}$

Several other writers used exactly the same formulation. ${ }^{176}$

There was a vigorous debate on the matter, with de hua proponents frequently citing the proposition that the Yi did not love virtue in order to refute it. ${ }^{177}$ An article in a short-lived Guomindang journal focused on Liangshan argued eloquently:

There are those who say that "the Yi do not cherish virtue and can only be ruled through force." But those people should ask themselves whether or not they display any virtue for the Yi to cherish? ${ }^{178}$

The de hua-ists and the wei wei-ists (those who believed that the Yi could only be ruled through force) interpreted historical and myth-historical precedent differently. James Sheridan has commented that in the Republican period the two sword-and-honour Ming historical epics Romance of the Three Kingdoms (San guo yan yi 三國演義) and Heroes of the Water Margin (Shuihu zhuan 水狺傳) were “particularly influential in shaping attitudes [...], general views and specific behavior”. ${ }^{179}$ Zhuge

\footnotetext{
${ }^{175}$ Liu Yuetian 劉躍天, "Zhengli Yanyuan Yi wu chu yi 整理鹽源夷務芻議," Kangdao yuekan 2, no. 4 (1939): 22.

${ }^{176}$ For example Chang Longqing, Lei Ma E Ping diaocha ji, 40.

${ }^{177}$ See Zeng Zhaolun, Da Liang Shan Yi qu kao cha ji, 41; Wu Luzhong 吳魯仲, "'Yi wu wenti" lungang 『夷務問題』論綱," in Xikang sheng jianshe xie jin hui hui wu nianbao: di san ci 西康省建設協進會會務年報: 第三次 (Xichang: Xichang Ning yuan yinshua gongsi, 1948), 65.

${ }^{178}$ Kang Run 康潤, "Wo duiyu dangqian zhi yi de yijian 我對于當前治夷的意見," Daliangshan 大涼山 1, no. 1 (1946): 2.

179 James E. Sheridan, China in Disintegration: the Republican Era in Chinese History, 1912-1949 (New York: Macmillan, 1975), 100. Romance of the Three Kingdoms had also served as a guide to military and administrative strategy throughout the Qing dynasty. Hong Taiji commissioned its translation into Manchu, purportedly so that it could serve as a strategy manual for his generals. By his own account, the general Eldemboo, who successfully repressed the White Lotus rebellion (1796-1804), was highly influenced by the work. Pamela Kyle Crossley and Evelyn Sakakida Rawski, "A Profile of the Manchu Language in Ch'ing History," Harvard Journal of Asiatic Studies 53, no. 1 (1993): 93-94.
} 
Liang 諸葛亮, the Three Kingdoms-era (220 to 280 AD) chancellor of Shu Han and one of the key protagonists in Romance of the Three Kingdoms, was a hero to governors in the Southwest for the way he had successfully subdued the rebellious "Southern Barbarians" (nan man 南蠻) and their stubbornly recalcitrant leader Meng Huo 孟獲. But there was disagreement between the de hua-ists and their opponents about what exactly the lesson in Zhuge's exploits was. According to the novel, Zhuge won the hearts and minds of the "Southern Barbarians" (nan man 南蠻) by capturing their rebellious leader Meng Huo seven times and releasing him each time without punishment. Distilled into the aphorism "take your enemy seven times, let him go seven times” (qiqin qizong 七擒七縱), Zhuge’s strategy was usually seen as a "hearts-and-minds" approach to warfare and governance. ${ }^{180}$ But the fundamental question for twentieth century officials was whether or not this was the reason that the Barbarians had submitted to him. Liu Wenhui wrote:

Many people say "the character of the Yi is like that of dogs or goats; they can only be ruled through force and have no love of the good."181 They point out that when Zhuge Liang campaigned in the south and captured Meng Huo seven times and then released him seven times, afterwards Meng Huo said "Your Excellency's divine power and prestige (tian wei 天威) ${ }^{182}$ ensures that the south will not rebel again.”

\footnotetext{
${ }^{180}$ In Romance of the Three Kingdoms the "hearts-and-minds" strategy is proposed by Ma Su. The Chinese text has "gong xin wei shang, gong cheng wei xia; xin zhan wei shang, bing zhan wei xia 攻心為上, 攻城為下; 心戰為上, 兵戰為下” (Luo Guanzhong 罗贯 中, San guo yan yi 三国演义 (Harbin: Heilongjiang chubanshe, 2003), 362.) Moss Roberts translates this as "The enemy's mind is more important than his city; psychological struggle is superior to armed struggle.” (Luo Guanzhong, Three Kingdoms: a Historical Novel, trans. Moss Roberts (Berkeley: University of California Press, 1991), 362.) I am not sure that this conveys the right impression. "Psychological struggle" could mean destroying an enemy's morale through terror. In the story, Ma and Zhuge's strategy is focused on demonstrating superiority but giving the enemy no cause to feel aggrieved or hard done by. If it is shorn of any connotation of giving aid to a civilian population, "winning hearts and minds" seems a more appropriate translation of gongxin 攻心 (literally "attack the heart-mind") in this context.

${ }^{181}$ The words Liu Wenhui uses here are exactly the same as Liu Yuetian's.

${ }^{182}$ Moss Roberts translates this as “divine prestige”, but for our purposes it is important to be aware that wei 威 is the same character as used in the expression "the Yi only can only be ruled through fear (wei 畏) of force (wei 威)”. Wei 威 is used in collocations like weili 威力 “power, might” and weixie 威脅 “threaten, imperil”; as well as in collocations like
} 
He did not say “Your Excellency’s great moral virtue (sheng de 盛德) ensures that the south will not rebel again." [Therefore, many believe that] the reason that the southerners did not rebel again was the chancellor's great power and prestige, not his great moral virtue. [They argue that] Meng Huo's words demonstrate that the Yi can only be ruled through force, and have no love of the good. [...] I do not completely agree with this interpretation. Why not? Because, in general, the nature (tianxing 天性) of all people is the same. As the ancients said “in their nature men are alike (xing xiang jin ye 性相近也 )"183. And also "we are not made of wood and straw, nobody is without feeling” (ren fei cao mu, shu neng wu qing 人非草木, 孰能无情), which also indicates the basic similarity of all humans."

"We are not made of straw and wood", is found in Heroes of the Water Margin and indicates that although a person is not showing a certain emotion, they are nonetheless feeling it as surely as they are not made of "wood and straw". ${ }^{185}$ The Yi, like their purported ancestor Meng Huo, did not always openly acknowledge the virtue of Liu's government, but they knew about it as much as anyone else with flesh and blood. Liu Wenhui's view here was essentially the same as that argued by Wu Guangyao吳光耀 in the 1920s. Wu had been critical of Zhao Erfeng's ruthlessness, and argued that:

The birds, beasts and insects all have a sense of revenge, and the Yi, our own kind, how could they not? Focusing on their hearts and minds, Zhuge Liang, was able to end the rebellions of the southerners. He was a truly great leader (shen ren 神人). ${ }^{186}$

weixin 威信 “prestige” and weifeng 威風 “air of importance, dignity”. The sentence quoted by Liu here is from Luo Guanzhong 罗贯中, San guo yan yi, 376.

${ }^{183}$ This is from the Analects of Confucius (Lun yu 論語), where the full sentence is “In their nature men are alike; in their habits they are different (xi xiang yuan ye 习相远也). (Lun $y u$ 論語, 17.2) Or in Simon Leys' translation: “What nature put together, habit separates." The Analects of Confucius, trans. Simon Leys (New York: W. W. Norton, 1997), 85.

${ }^{184}$ Liu Wenhui, "Ningshu Yi wu wenti zhi jiantao," 4.

${ }^{185}$ Shi Nai'an and Luo Guanzhong, Outlaws of the Marsh, trans. Sidney Shapiro, 3 vols., vol. 1 (Beijing: Foreign Languages Press, 1980), 263.

${ }^{186}$ Wu Guangyao 吳光耀, "Xizang gailiu ben wei ji 西藏改流本未紀," in Kangqu Zangzu shehui zhenxi ziliao jiyao (shang), ed. Zhao Xinyu, Qin Heping, and Wang Chuan (Chengdu: Bashu shushe, 2006), 107. 
According this interpretation, the barbarians had submitted not because of the chancellor's “power and prestige”, but because Zhuge had not given them cause to seek revenge and thereby won over their hearts and minds. Interestingly, on all sides, there was a recurring comparison between human and animal. For Wu, animals and humans (including both Yi and Han) were alike, with the implication that the same methods of pedagogy are appropriate for all. The hawkish and racist opponents of Wu's view also founded their argument on a comparison with animals, but one in which only the Yi were likened to animals, which put Han in a separate "virtuecherishing” category.

Others who pondered the question of whether force or virtue was required for governing the Yi were also drawn to Zhuge Liang, though they were not always able to make up their minds about the lesson in the history. As an author of a 1946 article in a short-lived Guomindang sponsored journal focused on Liangshan mused in his opening lines:

If one asks: "For governing the $\mathrm{Yi}$, what are the merits of coercion (wei) and virtue (de)?” one could do a lot worse than to recall Zhuge Liang's conquest of the Southern Barbarians and ask for what reason did he adopt the "take your enemy seven times, let him go seven times" strategy? ${ }^{187}$

However, this writer, who used the penname "Random Thoughts", did not have a clear answer, other than to say that de was not the same as "giving out salt, wine and cloth", while wei "might mean the killing of some of the most wicked villains". ${ }^{188}$ It was elliptical comment that was probably a rejoinder to criticisms that de amounted to bribery and wei indiscriminate killing. But more than anything, the writer's words demonstrate both the tendency of Republican period officials to foreground the question of ethics in government, as well as the trouble that many experienced believing that virtuous rule was really the key to resolving the troubles of the frontier.

\footnotetext{
${ }^{187}$ Xin kou 信口 ['Random Thoughts'], "Wo shuo wo de 我說我的," Daliangshan 大涼山 1, no. 1 (1946): 22.

${ }^{188}$ Ibid.
} 
Tonghua 同化, Assimilation, and Jinhua 進化, Progress

For those who concluded that the Barbarians could only be ruled through force, Liu's second transformation, assimilation (tonghua 同化), was of the utmost importance. For believers in the de hua cause, who had faith that the ethnic other would respond to virtuous rule, the eradication of ethnic otherness was not so critical, but it was, nonetheless, not to be neglected. However, many leaders were contradictory and unclear about what tonghua actually meant.

In chapter two, I argued that Elliot Sperling's view that Zhao Erfeng wished to "sinicize Kham as far as possible" is not a bad general summation, though it is important to recognize that Zhao's regulations promoted a specific kind of Chinese society. Just as his settlement policy differed from Lu Chuanlin's proposals and the system in place in Manchuria, Zhao's ideas about the transformation of indigenous society were also clearly distinct from later Han leaders in the Sichuan frontier.

A formula from the Book of Rites ( $L i$ ji 禮記) that has often been quoted in discourse on the governing of non-Han people is: "Put their morals and manners in order, but do not alter their customs. Regulate their laws and government, but do not change their ways of doing things (xiu qi jiao bu bian qi su, qi qi zheng bu yi qi yi 修其教不變其俗，齊其政不易其宜).”189 Clearly there is some amount of ambiguity as to the line between "morals and manners" and "customs", as well as that between "laws" and "ways of doing things.” This ambiguity has allowed these lines to be cited by rulers as disparate as the Kangxi emperor (in reference to governing Xinjiang) and Liu Wenhui (see below). ${ }^{190}$ Zhao also riffed on the same formulation, but in a way that more clearly suggested policy objectives: "Preserve their teachings [jiao 教, translated as “morals and manners” above], but change

\footnotetext{
${ }^{189}$ See Zheng Xuan 鄭玄 and Kong Yingda 孔穎達, eds., Li ji zheng yi 禮記正義 (Shanghai: Shanghai guji chubanshe,1990), 246.
${ }^{190}$ Wang Hui 汪晖, Xiandai Zhongguo sixiang de xingqi, shang juan, di er bu: diguo yu guojia 现代中国思想的兴起，上卷，第二部：帝国与国家 (Beijing: San lian shu dian, 2008), 541; JKDZ, 75.


their government (cun qi jiao yi qi zheng 存其教易其 政)”. ${ }^{191}$ Moving further away from the terms in the Book of Rites, he went on: "eliminate their superstition, send in civilization (shu yi wenming 輸以文明), strengthen their race (qiang qi zhongzu 強其種族).”

From a later perspective it may seem astounding that Zhao could have wanted to "strengthen" the "race" that he spent so much effort fighting, but the comment makes sense in light of Zhao's understanding of the causes of the problems on the frontier. The Qing leaders did not have a strong conception of non-Han nationalism within their empire. Revolts were the work of particular unruly leaders or foreign imperial powers, both of whom led poor and poorly educated commoners astray. Rebellion did not signify a desire on the part of ordinary people in a particular population to have their own nation-state. Zhao's stated goal of "strengthening their race” is also consistent the views attributed to him by Fu Songmu in his great tribute to Zhao Record of the Establishment of Xikang Province. Fu's work included a series of idealized dialogs in which Tibetan people argue with Zhao, contesting that their ways of doing things were better than Han ways that Zhao required they adopt. In each case, Zhao hears them out and then proceeds to demonstrate the correctness of his policies (and by extension Han culture) with such logic and clarity that the Tibetans are forced to concede they were wrong. ${ }^{192}$ Zhao's arguments highlight how abandoning their customs would be good for the Tibetans. Ending polyandry would allow them to increase their population and become militarily stronger. ${ }^{193}$ Ending the religious taboo against mining mountains inhabited by spirits would mean more gold for "the printing of Buddhist texts, plating statues of the Buddha and for head ornaments for your women.” 194 The assimilationism of Zhao and Fu was premised above all on the assumption that certain Han practices were simply better than Tibetan ones. Adopting them would lead to a stronger and more prosperous society (or "race”) that

\footnotetext{
${ }^{191}$ QCBD, 2:488.

${ }^{192}$ Fu Songmu, Xikang jiansheng ji, 3:25-39.

${ }^{193}$ Ibid., 30-31.

${ }^{194}$ Ibid., 28, 30-31.
} 
would not be vulnerable to foreign scheming and infiltration or manipulation by deviant local leaders.

Liu Wenhui's tonghua was quite different. He construed it as the opposite of what he saw as the flawed historical policy of "segregation" (fenhua 分化). ${ }^{195}$ For Zhao, the key problem had been that wrong-headed and "superstitious" Tibetan cultural practice prevented the development of a prosperous and civilized society. For most Republican period writers, the fundamental challenge was the lack of unity between Han and non-Han communities, which led to conflict and "mutual enmity". ${ }^{196}$ Tonghua was a response to the boundary between ethnicities, not the culture on the nonHan side of the boundary. This is not to say that Liu was entirely unconcerned with that culture. To eliminate the boundary, culture would have to be changed in some way. Yet it was far from clear exactly what kinds of changes were necessary in any given context, or how far they would have to go.

Heather Stoddard sees a direct link between Liu Wenhui's tonghua and the Cultural Revolution:

[Liu Wenhui] estimated that through education "within ten to twenty years the people will have forgotten even the names of the minority groups." Liu Wenhui [...] revealed in this bald statement not only the continuing intentions of the Chinese for the complete assimilation of Tibet from the start of the twentieth century, culminating in the total effacement of all specific cultural identity during the Cultural Revolution, but also the enormity of the misunderstanding among Chinese of non-Chinese people. ${ }^{197}$

\footnotetext{
195 Liu Wenhui, "Jianshe xin Xikang shi jiang," 602.

${ }^{196}$ Wu Liucun 伍柳邨, "Yimin jiancun chuyi -- wei shixian sanhua zhengce er jianyi de yi zhong zhidu 移民建村媰議--為實現三化政策而建議的一種制度," Bianzheng yuekan 邊政月刊 1, no. 4-8 合刊 (1944): 47.

${ }^{197}$ Heather Stoddard, "Tibetan Publications and National Identity," in Resistance and Reform in Tibet, ed. Robert Barnett and Shirin Akiner (Bloomington and Indianapolis: Indiana University Press, 1994), 125.
} 
Other historians have also attributed the same claim to Liu. ${ }^{198}$ The idea that people would have forgotten even the names of the minority groups within twenty years appears to be slightly misattributed. Barnett reported that a general in the Twenty Fourth Army (not Liu Wenhui) made this comment to him. ${ }^{199}$ But I have not encountered any primary source directly linking Liu himself to this view. Liu's own comments on assimilation are inconsistent.

In one instance, discussing the $\mathrm{Yi}$ in particular, he did indeed suggest that the complete erasure of Yi identity was necessary. "Only when the Yi people have become Han people will the Yi problem be completely solved." ${ }^{200}$ On one occasion in 1945 he also explained the tonghua policy as "in the spirit of 'using Chinese Civilization to transform the barbarian' (yong Xia yi bian Yi 用夏以變夷).” ${ }^{201}$ However, Liu did not follow Zhao in attempting to prohibit practices such as sky burial. In a speech delivered on January 1 1939, he had actually criticized the notion of "using Chinese Civilization to transform the barbarian”:

Zhao Erfeng exerted himself with great diligence. However he was constrained by the notion of 'using Chinese Civilization to transform the barbarian', and therefore his administration and policy were extremist. $^{202}$

It was in this speech that Liu cited the Book of Rites on governance of the ethnic others on China's edges. As we saw in chapter six, the governors of the twentieth century Sichuan frontier often showed a striking lack of

\footnotetext{
${ }^{198}$ June Teufel Dreyer, China's Forty Millions: Minority Nationalities and National Integration in the People's Republic of China (Cambridge, Massachusetts: Harvard University Press, 1976), 37.

199 A. Doak Barnett, China on the Eve of Communist Takeover (New York: Frederick A. Praeger, 1963), 224.

${ }^{200}$ Liu Wenhui, "Ningshu Yi wu wenti zhi jiantao," 4.

${ }^{201}$ Quoted in Wang Chuan, "Minguo zhong-hou qi de zhengzhi yu zongjiao: Liu Wenhui yu Xikang diqu zangquan fojiao jie 民国中后期的政治与宗教：刘文辉与西康地区藏 传佛教界," in Yijiusanling niandai de Zhongguo 一九三 0 年代的中国, ed. Zhongguo shehui kexue yuan jindaishi yanjiusuo minguo yanjiushi 中国社会科学院近代史研究所 民国研究室 and Sichuan shifan daxue lishi wenhua xueyuan 四川师范大学历史文化学 院 (Beijing: Shehui kexue wenxian chubanshe, 2006), 805-06.
}

${ }^{202} \mathrm{JKDZ}, 75$. 
knowledge concerning historical engagement with the frontiers. Therefore it is uncertain whether Liu had any specific previous citation of this formulation in mind (like Kangxi on Xinjiang). But even if he did not, the quotation still suggests a very different approach from one that aimed for the complete erasure of non-Han culture and identity. On another occasion, Liu wrote that if "the existing order" was completely overturned, it would be "very difficult for the new order to succeed it". ${ }^{203}$ Liu's stated position here was in direct contrast to that of Chen Zhongwei, who argued for a "development plan [that was] nothing less that the overturning of all the elements of the existing social order."204 The quotes from Liu above were perhaps intended for different audiences, or Liu might have held genuinely mixed feelings on the matter. It is also possible that he believed that the $\mathrm{Yi}$ would have to be completely assimilated because they seemed more problematic, while Book of Rites style tolerance of difference could apply in Kham.

On some occasions he was perhaps writing for an audience that included indigenous leaders, yet a fondness for Tibetan Buddhism was manifest in more than just words. From 1938 he funded the establishment of Wuming 五 明 (“Five Sciences”) Buddhist Colleges in several places in Xikang, the largest one being the Western Borderlands Buddhism College in Dartsedo. ${ }^{205}$ The official purpose of these institutions was to "link up Tibetan and Han culture; to integrate politics and education/religion in the Kham region; to unite the people’s hearts and minds (tuanjie ren xin 團結人 心); and to consolidate the nation’s rear.”206 To further these aims monks from monasteries around Kham were given government stipends and travel allowances for periods of study. The curriculum was loosely based on a classical Tibetan-Indian Buddhist formula, and was taught by lamas who used the colleges' collections of classical Chinese and Tibetan works.

\footnotetext{
203 JKDZ, 52.

${ }^{204}$ Chen Zhongwei, Xikang wenti, 250.

${ }^{205}$ Wang Chuan, "Minguo zhong-hou qi de zhengzhi yu zongjiao," 809.

${ }^{206} J K D Z, 322$.
} 
Ren Naiqiang's writing on assimilation demonstrated similar contradictions. Citing Newton's Law of Gravity, he formulated a "Law of Assimilation":

Among two races (minzu) their respective powers of assimilation (tonghua li 同化力) are directly related to the level of their culture (wenhua chengdu 文化程度), and inversely related to their distance from each other. ${ }^{207}$

The discovery of this principle led him to conclude that the people he called "Fan”, the indigenes of the east of Kham, would be assimilated by the Han within only ten years, and that with the proper civilizing (jiaohua 教化) program, this would be as "easy as turning over one’s hand.” ${ }^{208}$ However, there is a degree of mismatch between this blunt statement and many of his practical suggestions for bringing about greater unity between the Han and the indigenous people. The latter almost all involve the Tibetan-ization of the Han, rather than the Han-ization of the Tibetans. He argued that it was necessary for administrative personnel to be able to understand local languages. ${ }^{209}$ To this end, he suggested the establishment of better academies where Han people could learn indigenous languages in a more comprehensive way than they had in the past. He praised the Shaanxi merchants who had created a Chinese-Tibetan phrasebook, and suggested that it be published and made available to Han in Xikang. ${ }^{210}$ One of the abilities he listed as being desirable in new settlers was being able to speak the Barbarian (yi 夷) languages, or at least being young and clever enough to learn them. ${ }^{211}$ Another desirable characteristic was having an understanding of Buddhism. Furthermore, he suggested that inns in Chengdu should serve Tibetan food and butter tea and have Tibetan-Chinese

\footnotetext{
${ }^{207}$ Ren Naiqiang, Xikang tujing: minsu pian, 234.

${ }^{208}$ Ibid., 221-22.

${ }^{209}$ Ibid., 224.

${ }^{210}$ Ibid., 229.

${ }^{211}$ Ibid., 296.
} 
interpretation services in order to encourage more Khampa and central Tibetan merchants to visit the Interior. ${ }^{212}$

The question of whether assimilation (tonghua) was the same thing as Han-ization (Hanhua 漢化) was rarely addressed directly, yet it is clear that there was a great deal of uncertainty on this matter as well. On the one hand, Han-ization was exactly what some observers prescribed. Wu Luzhong wrote:

In our view, the key to solving the Yi problem is the elimination of the differences between the $\mathrm{Yi}$ and the Han, which is to say that the complete Han-ization of the Yi and the abolition of the Yi territories is required. On this point there can be no disagreement. ${ }^{213}$

On the other hand, as we have seen, some critics argued that the Hanization being spread by the "criminals" and men with "undesirable social habits" whom they believed constituted the bulk of migrants to the highlands was nothing more than "the spread of vulgar attitudes of marketplace.” If this was the case, the project to reshape indigenous culture had to aim a little higher than Han-ization. Perhaps this was the reason that Chen Zhongwei conceptualized the transformation of indigenous society as the use of “civilization”, rather than “Chinese culture” (Xia 夏) to overthrow “barbarism” (yi wenhua hua yeman 以文化化野蠻). ${ }^{214}$ Chen was extraordinarily dismissive of indigenous culture, but almost equally impressed with the need to reform Han society. He was a democrat after the fashion of Sun Yat-sen, and called for the abolition of the death penalty, the emancipation of women, universal free education and health care, and an eight-hour day. ${ }^{215}$

The connection (or lack thereof) between Han-ization and assimilation had practical importance for education policy. Most officials believed that non-Han people should attend government-sponsored schools of some form.

\footnotetext{
${ }^{212}$ Ibid., 232-33.

${ }^{213}$ Wu Luzhong "'Yi wu wenti" lungang," 70.

${ }^{214}$ Chen Zhongwei, Xikang wenti, 251.

${ }^{215}$ Ibid., 304-05.
} 
But whether they should be educated in the same schools as Han Chinese, and what status should be accorded to Chinese and indigenous languages were matters of debate. Some officials believed-in the tradition of Zhao Erfeng - that education should be entirely in Chinese. ${ }^{216}$ Others advocated “Chinese content with Tibetan explanations”; while another group argued for full bilingualism. Ren Naiqiang suggested that proposed schools for the sons of headmen should teach Chinese language, but that other subjects should be in Tibetan. ${ }^{217}$ Concerning education in the $\mathrm{Yi}$ areas, Huang Yanpei considered it vital for teachers to be able to speak local languages, and argued that there should indeed be separate schools for Yi and Han students, because "their knowledge and habits are all different."218

Other commentary that tried to fill out what assimilation and an assimilation policy would mean in practice referred to the American ideal of a melting pot, from which a “new nationality” (xin minzu 新民族) had emerged. ${ }^{219}$ It was perhaps in this vein that several writers argued for the government to adopt measures to encourage intermarriage between Han and non-Han. ${ }^{220}$ In chapter two we saw that Zhao Erfeng gave extra rations to soldiers who married Tibetan women. It is unclear whether he did this because he wished to encourage intermarriage for assimilationist reasons, or because he believed that soldiers who settled down and started families could eventually become less dependent on the state for food and wages. The Republican period writers who advocated measures to encourage intermarriage had unambiguously assimilationist motives. It would

$216 \mathrm{JKDZ}, 394$.

${ }^{217}$ Ren Naiqiang, Xikang tujing: minsu pian, 233.

${ }^{218}$ CKSB, 173.

${ }^{219}$ Liu Yuanxuan 劉元瑄, "San hua zhengce yu san min zhuyi 三化政策與三民主義," Bianzheng yuekan 邊政月刊 1, no. 4-6(合刊) (1944): 35.

${ }^{220}$ Huang Shuyu 黃樹玉, "Jianshe Xikang ying cezhong Ningshu 建設康西康應側重甯屬 , Kangdao yuekan 康导月刊 1, no. 5 (1939): 165; Cheng Yuqi 程裕淇, Xikang jianying 西康剪影 (Duli chubanshe, 1945), 23; Li Yunheng 李辒珩, "Jianshe Xinan chubu guofang zhong zhi Xikang wenti 建設西南初步國防中之西康問題," Xibei wenti jikan 西北問題季刊 2, no. 1 (1936): 31. Colin Mackerras and Justin Tighe have noted similar arguments in Guizhou and Suiyuan respectively. Colin Mackerras, China's Minorities: Integration and Modernization in the Twentieth Century (Hong Kong: Oxford University Press, 1994), 63; Tighe, Constructing Suiyuan, 189. 
“eliminate the racial barriers (zhongzu gehe 種族隔閬) and create harmonious emotional bonds between the Han and Yi." ${ }^{221}$ As noted above, such proposals conflicted with Chen Zhongwei's idea that Han migrants to the frontier should be accompanied by wives from the interior. Biological mixing and melting pots might have fostered inter-ethnic ties, but they clashed with common notions about what was necessary to maintain good order. As far as I am aware, no frontier government in the Republican period actually adopted any policy to encourage intermarriage.

Liu Wenhui's third transformation was jinhua 進化, “progress”, which he posed against what was, in his interpretation, the historical policy of jimi 羈縻, “loose rein governance”. ${ }^{222}$ Thus Liu’s idea of jinhua did not specifically emphasize the development of infrastructure, which, as we shall see below, has often dominated later discussions of progress and modernity. Liu's government built roads and an airstrip at Kangding, but jinhua was more than this. If de hua was aimed at the Han authorities, tonghua at the boundary between Han and non-Han, then jinhua focused on indigenous society, calling for authorities to adopt an interventionist, rather than a laissez-faire approach. “A jinhua policy aims to set them in 'motion' (qiu qi 'dong' 求其 ‘動’ ), while a jimi policy aims to keep them 'static' (qiu qi 'jing’ 求其 “靜” )’. 223 At this point, Liu raised the worry that does not seem to have occurred to Zhao when he argued for "strengthening" the Tibetan "race”. "It is possible,” Liu wrote "that some people will think that, from a Han perspective, the progress of the border people brings certain dangers, and that the maintenance of jimi policies would be more stable.”224 He countered this with a rather perfunctory and obliquely argued point about uneducated people not knowing what was good for them. The border would be more stable if its ignorant residents were educated enough to

\footnotetext{
${ }^{221}$ Huang Shuyu, "Jianshe Xikang ying cezhong Ningshu," 165.

${ }^{222}$ Liu Wenhui, "Jianshe xin Xikang shi jiang," 605.

${ }^{223}$ Ibid., 606.

${ }^{224}$ Ibid.
} 
know what was in their best interests. It was here Liu came closest to Zhao Erfeng's paternalism. Yet jinhua was the last and least developed of the three hua. Liu did not identify specific elements of indigenous culture that would have to go or follow up with a raft of interventionist policy and legislation for their replacement with Han customs.

“Assimilation" and "progress" were powerful concepts in early twentieth century Chinese thinking regarding non-Han territory and people. But they were ill-defined, and what they would mean in practice was usually unclear. Different writers conceptualized them in different and often contradictory ways. Proposed policy steps for encouraging "assimilation” ranged from offering rewards for inter-marriage to publishing phrase-books for Han to learn local languages; from forcing the indigenous people to attend Chinese schools, to the establishment of government-funded monastic education institutions which would use Tibetan classics in instruction. In an important speech on Kham, Liu cited the famous call in Book of Rites for frontier leaders not to "alter the customs" of the people they ruled, but elsewhere he argued for the vanishing of Yi identity.

Xikang in the Late Twentieth and Early Twenty First Century.

The following discussion searches for echoes of Republican period discourse in the post-Mao era, returning to each of the themes analyzed above to investigate the extent of intellectual continuity and change over the second half of the twentieth century. Scholars investigating historical Chinese engagement with the south-western highlands often start or finish their work with references to present-day resonances of the key themes of their subject matter. Wang Xiuyu concludes his thesis with:

The call of the present government for the "great development of the west” (xibu dakaifai 西部大开发) is a call, historically speaking, for implementing the late Qing vision with greater intensity. ${ }^{225}$

\footnotetext{
${ }^{225}$ Wang Xiuyu, "China's Last Imperial Frontier," 369; See also: Liu Xiangxiu 刘祥秀 and Guo Pingruo 郭平若, "Qing mo tun ken zhengce zai Chuanbian Zang qu de shishi ji dui
} 
Nor is it uncommon for officials and institutions working on projects under the auspices of the Xibu dakaifa to note the importance of historical antecedents of the policy. In 2000, the Sichuan provincial government, the Chengdu city authorities and Sichuan University jointly established a Western Development Research Centre (Xibu kaifa yanjiu yuan 西部开发 研究院) to do research relating to the Xibu dakaifa policies. An historian, He Yimin 何一民 from Sichuan University, was appointed to be the vicedirector of the center, and has subsequently written about development policy in the Tibetan regions in the early twentieth century. ${ }^{226}$

Continuities between past and present are widely perceived as important and relevant, but they have not been examined in detail. This leaves comparisons between then and now as little more than garnish for introductions and conclusions, despite their widely acknowledged significance. Which were the truly enduring ideas of the early twentieth century? Which ideas have dissipated? And which have persisted, but undergone considerable change?

The Republican period produced dualistic representations of settlers and exactly the same duality has been present in later eras when political migration returned to the national developmental agenda. The pioneers of the Mao era were the zhiqing 知青, the educated youth who either volunteered for or were sent to positions in countryside during the late 1960s and 1970s. The zhiqing did not only go to frontier regions, but the most powerful and enduring representations of them have been set in places on the nation's periphery. Such narratives therefore act as vectors for the representation of engagement with frontiers, as well as of the zhiqing.

huanjing de yingxiang 清末屯垦政策在川边藏区的实施及其对环境的影响," Xizang yanjiu 西藏研究, no. 2 (2007): 16.

${ }^{226}$ He Yimin 何一民, "20 shji chu nian Chuanbian Zangqu zhengzhi jingji wenhua gaige shulun 20 世纪初年川边藏区政治经济文化改革述论," Xinan minzu xueyuan xuebao 西 南民族学院学报 (哲学社会科学版) 22, no. 6 (2001). He’s main area of interest as an historian, however, is the development of Chinese cities. 
Liyan Qin has given an insightful analysis of two contrasting constructions of the zhiqing, as manifest in Wang Xiaobo’s 王小波 (19521997) Golden Age 黄金时代 and Liang Xiaosheng’s 梁晓声 (1949-) Snowstorm Tonight 今夜有暴风. ${ }^{227}$ Liang Xiaosheng's novel is a narrative about heroes, while Wang Xiaobo's is the tale of a hooligan. The former is dominated by the ideology and aesthetics of the sublime. The characters are "obsessed with transcending the human, not only in speech and feeling but also in action.”228 The protagonist of the novel sacrifices herself to the ideals of the sent-down youth, is impeccably virtuous and remains chaste throughout her love affair. In Golden Age, however, the protagonist attempts to escape politics. His main goal is sex, and he is attracted to the lifestyles of the 'noble savages' who live in the mountains of Yunnan where he has been sent.

The same modes of representation exist among memoirs of zhiqing life in the Sichuan frontier. An article titled "Old Zhiqing, Old Photos, Old Stories” first published in the Liangshan Daily 凉山日报 and later republished on several websites, bears many similarities to Snowstorm Tonight.

All sorts of feelings and memories welled up in Wang Shaocheng's mind: There were tears and blood, but it was that tumultuous time that forged our strong will. The common people are really something! [...] In most cases, after the zhiqing returned to the city, they kept struggling just as they had in the countryside. ${ }^{229}$

\footnotetext{
${ }^{227}$ Liyan Qin, "The Sublime and the Profane: A Comparative Analysis of Two Fictional Narratives about Sent-down Youth," in The Chinese Cultural Revolution as History, ed. Joseph W. Esherick, Paul G. Pickowicz, and Andrew G. Walder (Stanford: Stanford University Press 2006), 240-66.

${ }^{228}$ Ibid., 241.

${ }^{229}$ Originally from Liangshan Daily, [original date of publication not given]. Reposted on the Liangshan TV site, apparently hosted by Sichuan TV: http://www.zgls.com.cn/ and also www.newssc.org. Also on Sichuan Zhiqing Wang 知青网 at http://sichuan.bbs1.kwbbs.com/ShowPost.aspx?topicid=571929\&ForumID=127545\&For umIndex $=1$
} 
A very different account of zhiqing life in Xichang was written and posted on the Internet by someone using the pen-name Chengdu Tanbeng. ${ }^{230}$ According to his account, the young Chengdunese in Liangshan were subject to a violent and arbitrary but also somewhat loose management regime. Youths had a degree of freedom to travel around, and to meet and fight with locals and other rusticated youth. On fighting, Tanbengzi comments “Liangshan blokes (hao han 好汉); if you haven’t fought, you don’t really know each other." The narrative is replete with kung-fu novel inflected description and lines such as: "The ancients say: 'there is also honour among thieves.' In the world of wanderers, you can't control your fate.” (ren zai jianghu shen bu you ji 人在江湖身不由己).” For the writer, 1970s Xichang becomes a kind of semi-mythological wuxia 武侠setting where “in those years friendship was really strong." Ties of comradeship were tight, but enmity among foes was correspondingly intense. While Tanbengzi's account of his own friends is highly positive, he portrays zhiqing society as dominated by clannishness, theft and group violence. The other rusticated youths are much more like the hooligans in Golden Age than the heroes of Liang Xiaosheng's novels or the strugglers in the Liangshan Daily article.

The two conflicting modes for representing zhiqing life in the frontier strongly resemble the Republican era's twin visions of settler society. There is the idea of bold pioneers on a mission of national importance, willing to tough it out in a harsh landscape in order to bring about revolutionary transformation. This is balanced by a narrative in which the pioneers are really hooligans, thriving in a frontier chaos. Granted, the hooliganism of the zhiqing is not quite the same as the hooliganism of the "dregs of Han society” who aroused disappointment and ire in Xikang officials. Chengdu Tanbengzi and Wang Xiaobo give a more positive impression of a wild, rough-and-tumble frontier lifestyle than Ren Naiqiang or the county magistrates in 1930s Kham did. But they are accounts that come from different perspectives. If the hooligans of the 1930s had written narratives

\footnotetext{
${ }^{230}$ Chengdu Tanbengzi 成都弹朋子, "Chongfan Daliangshan 重返大凉山", Chengdu Tanbengzi Tianya blog 天涯博客, http://blog.tianya.cn/blogger/view blog.asp?idWriter $=0 \&$ Key $=0 \& B \operatorname{logName}=$ cdtanbengzi \&CategoryID=283408\&page $=3 \& b=1 \& r=3 \&$ nextid $=88888888$ [accessed 18 May 2011].
} 
perhaps they would have added some element of counter-cultural wuxia romanticism as well.

The Chinese Communist Party was part of the same revolutionary tradition as the Guomindang and Liu Wenhui, which saw frontier problems as the result of immoral governance. Socialist narratives of the history of the frontier region have almost always contained a sentence such as the following one, from Welcome to Da Liangshan (Zoujin Daliangshang 走进 大凉山): “The ethnic discrimination and oppression of minority ethnic groups implemented by historical dynasties and the Guomindang ruling clique led to profound ethnic barriers." ${ }^{231}$ Similarly, a recent article on the Long March’s passage through the region states:

The reactionary Guomindang pursued policies of Han Chauvinism ( $d a-$ Han zhuyi 大汉主义), and did their utmost to oppress our Yi compatriots. This led to the development of formidable barriers between ethnic groups and intense ethnic conflict. ${ }^{232}$

Yet now that the Party no longer sees political transformation as the key to the further progress of the Chinese nation, the de hua story of history in which change was brought by a revolution in politics has also lost ground. A recently published book of photographs from Republican era Kham, 1939: Images of Xikang (1939 nian: zoujin Xikang 走进西康), almost entirely omits political transformation from its account of frontier history. The Long March did not foreshadow the end of "reactionary Guomindang” rule; it was merely “a moment's palpitation” within the timeless existence of the ancient village. ${ }^{233}$ Liu Wenhui is almost monastic-ised. The editor writes euphemistically that: "We should say that Liu Wenhui used some

\footnotetext{
${ }^{231}$ Xiong Junsong 熊峻松, ed., Zoujin Daliangshan 走进大凉山 (Chengdu: Sichuan minzu chubanshe, 2003), 61.

${ }^{232}$ Chen Guoguang 陈国光, "'Yihai jiemeng" de lishi chengji ji xianshi yiyi “彝海结盟”的 历史成绩及现实意义," Zhongyang minzu daxue xuebao 中央民族大学学报 32, no. 6 (2005): 24.

${ }^{233}$ Zhang Ming 张鸣 and Sun Mingjing 孙明经, 1939 nian: zoujin Xikang 1939 年: 走进 西康 (Jinan: Shandong huabao chubanshe, 2003), 23.
} 
amount of force (haishi yongguo yixie li 还是用过一些力) in the construction of Xikang during his decades in power."234 Nevertheless, the caption to his photo (below) makes his time in region seem like a hermitic retreat:

The expression he assumes shows grace, dignity and poise (yongrong 雍容); the aggressiveness and drive (ruiqi 锐气) of the years he spent seeking to dominate Sichuan has already disappeared. ${ }^{235}$

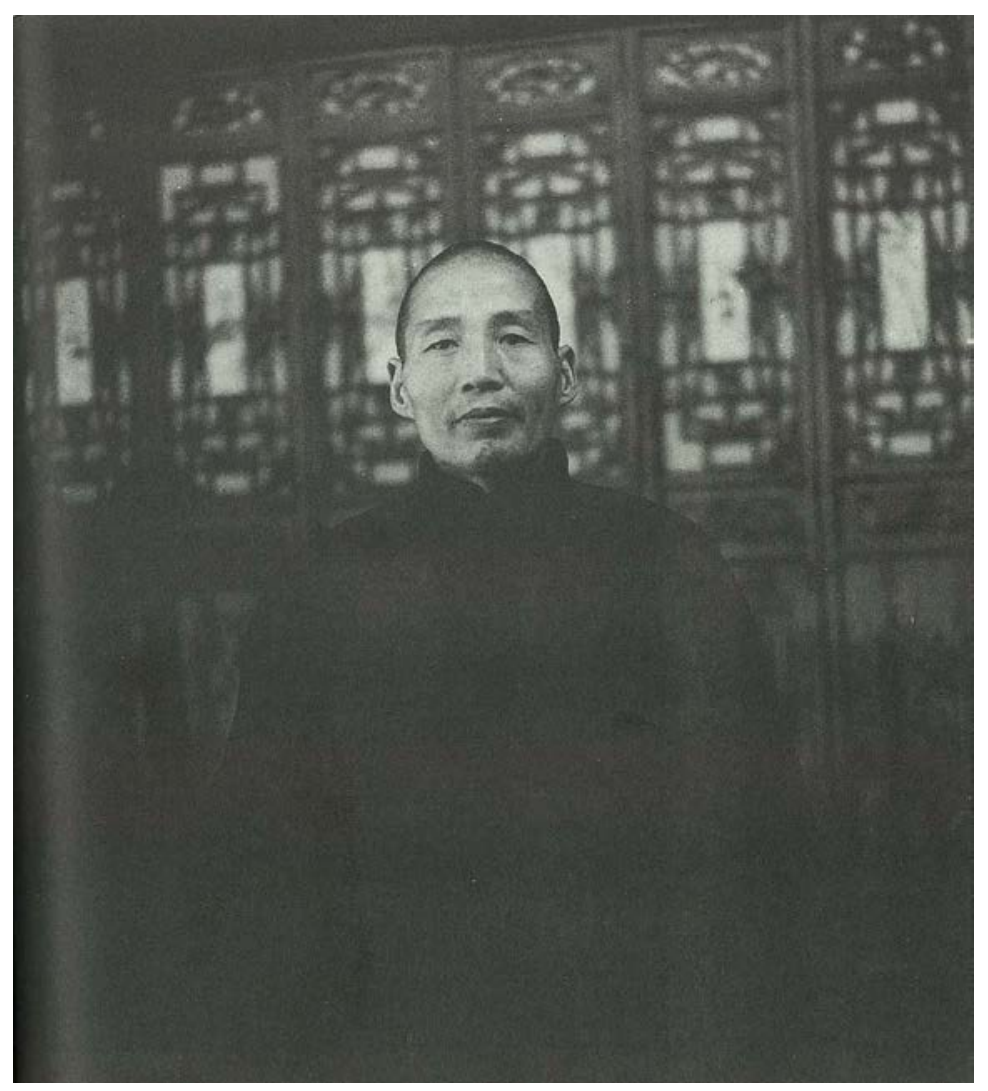

Liu Wenhui at 44. Photo by Sun Mingjing. ${ }^{236}$

The 1912 conflict between Sichuan governor Yin Changheng and the Lhasa government is present only through a poem written by Yin. The editors comment that the poem is "More than a little heroic, even if the use of 'barbarian’ [man 蛮] to refer to the Tibetans, which reflects the Han

\footnotetext{
${ }^{234}$ Ibid., 64.

${ }^{235}$ Ibid., 65.

${ }^{236}$ Ibid., 65.
} 
Chauvinism of the time, is not really appropriate." ${ }^{237}$ Poetic "Han Chauvinism" seems to be the most controversial thing that Yin did. Of Zhao Erfeng, they write "the reputation of this General, who gained infamy for his actions against the Railway Protection movement, was not so bad in the Kham frontier." ${ }^{238}$ He may have been "not so bad”, but it appears that there was nothing particularly remarkable about him either. In general, the book portrays late Qing and Republican period Xikang as a tough but benign backwater; a sleepy and largely neglected place characterized by distance from the kind of revolutionary transformation that was taking place in the rest of China.

In discourse that diminishes the role of political change in history, it is most often the notion of “modernity” (xiandai 现代) that takes over as the key rubric for understanding historical change. However, among post-Mao historical narratives there are at least two different ways of interpreting the nature and causes of modernization, both of which are distinct from Liu Wenhui's jinhua.

In 2007, a documentary series about the construction of the ChengduKunming railway aired on Chinese national state television. ${ }^{239}$ It seems likely that its production had something to do with the 2006 completion of another challenging railway in a non-Han territory with a history of unrest: the line from Golmud to Lhasa. This connection might explain why the documentaries portray the Chengdu-Kunming railway as the sole catalyst for all change in Liangshan: a "fifty-year leap into modernity”. The railway really did foster greater connections between Liangshan and the outside world. But the documentary promotes the notion that before the railway such connections did not exist at all. The Yi people are reported to have

\footnotetext{
${ }^{237}$ Ibid.

${ }^{238}$ Ibid., 219.

${ }^{239}$ Zhongguo zhongyang dianshitai 中国中央电视台, "Guo shan che: Cheng Kun tielu, Zhongguo tielu xiujian de qiji 国山车: 成昆铁路, 中国铁路修建的奇迹," (China: Zhongguo guoji dianshi zonggongsi, 2007).
} 
never heard of “China”. One surveyor comments: "They asked all sorts of strange questions, like 'is this place here bigger or is China bigger?'” This is suspiciously close to the words attributed to King Yelang 夜郎 in the fable from Records of the Grand Historian (Shi ji 史記) about the southern Barbarians whose ignorance of the size of the Han empire has literally become a by-word for naive self-importance (“yelang zida 夜郎自大”). ${ }^{240}$ Some Yi in Liangshan no doubt were ignorant of the broader national context. But the documentary makes no mention of the Democratic Reforms (Minzhu gaige 民主改革): the radical program to restructure of old Liangshan society and politics that was launched in 1956. During that movement, some 65 percent of commoners (laodong renmin 劳动人民) in Liangshan were reckoned to have been "fully mobilized” (fadong chongfen 发动充分) and a further 25 percent “relatively mobilized”. 241

Given that political transformation and virtue (de 德) are nonentities in the narrative presented by the railway documentary, the question of whether or not the Yi cherish virtue does not occur. But here it is not force (wei 威), but modern infrastructure that is necessary for ruling the $\mathrm{Yi}$, as the comment of one surveyor demonstrates.

When the train pulled into the station, an old Yi grandma kneeled down by the tracks. 'The shenxian's here' she said, because the front engine was draped in flags, and on the front was Chairman Mao's image.

Political power is evident, but in this case it is (literally) tied to and legitimized by the creation of physical infrastructure, not certain conceptions of morality. It is the government's capacity to deploy industrial machinery that inspires loyalty from the Yi. According to the documentary the construction of the railway led the Yi to sing a folk-song with the refrain “thank you, big brother”. Having thus won over the natives, the train sparks the great transformation of Yi society; in the same way that virtuous rule does in the de hua narrative.

\footnotetext{
${ }^{240}$ Sima Qian 司馬遷, Shi ji 史記 (Beijing: Zhonghua shuju, 1987), 2996.

${ }^{241}$ Xiong Junsong, ed., Zoujin Daliangshan, 68.
} 
In the case of other cultural productions, de hua remains evident but is combined with infrastructural-modernity in ways that suggest that the latter might be much more significant than the former. Figure one below shows a painting by one of China's most successful artists, Wang Weizheng 王为政 (1944-), of the "Yihai Alliance” (Yihai jiemeng 彝海结盟); a pact between the Long Marchers and an Yi chieftain. ${ }^{242}$

The work was part of a 2005 project organized by the China Painting and Calligraphy News (Zhongguo shuhua bao 中国书画报) to commemorate the seventieth anniversary of the Long March. The whole series went into space on board the Shenzhou 6 spacecraft, and was sold at auction after its return to earth to raise money for schools along the route of the Long March. On its own, the painting suggests the continuing importance of the idea of an historical moral transformation of politics. It conveys the orthodox vision of enlightened, post-de hua form politics and society: a social order characterized by a fastidious commitment to equality between Han and non-Han, and a chummy closeness between ruler and subject. Moreover, its creator is a serious, independent and highly respected artist, not an anonymous producer of propaganda.

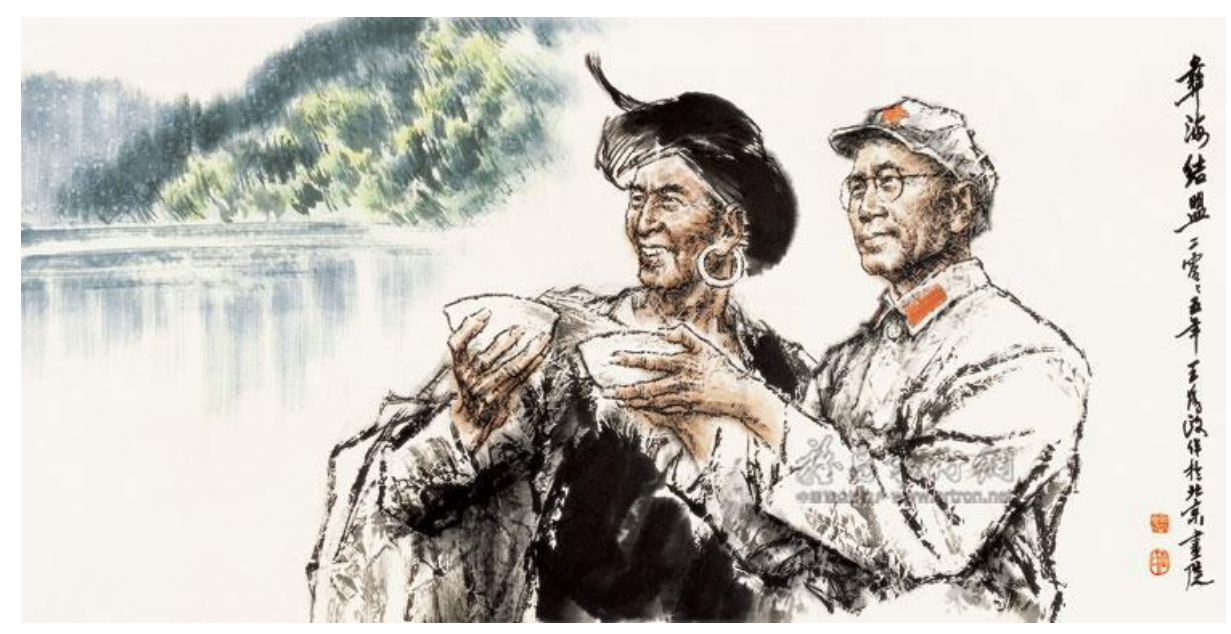

${ }^{242}$ Biographical information from Beijing Fine Arts Academy website: http://www.bjaa.com.cn/my/81/2008_12_26/1_81_2542_0_0_1230268432816.html\# (accessed 2 August 2010). 
Wang Weizheng's painting “The Yihai Alliance”, from Wang Weizheng's website. $^{243}$

Media constructions of the events surrounding the paintings, however, suggested an ambivalence about the importance of the paintings' subject matter. News articles made much of the Long March theme, but treated it quite differently from the article quoted on page 252, which castigated the immoral rule of the Guomindang. In reporting on the space-paintings, the Long March has no moral dimension. What mattered was its "spirit of optimism” (leguan zhuyi jingshen 乐观主义精神) and “heroic will” (yingxiong qi 英雄气). ${ }^{244}$

Other contemporary narratives also downplay the historical importance of a transformation in politics in favour of model of change that could be called “modernization". In the following cases, however, physical infrastructure and new technology like the Chengdu-Kunming railway or Shengzhou 6 is not at the core of the authors' conception of modernization. Instead, modernization means a new kind of economy.

One work that presents this view is a novel called Chen'ai luoding 尘埃 落定 (“When the Dust Settles”) by Alai 阿来 (1959-), a Tibetan writer who mostly writes in Chinese. ${ }^{245}$ The novel is told from the perspective of the 'wise-idiot' son of a tusi family in Republican period Kham. The book is replete with prophecies and images that suggest the total destruction and remaking of the characters' world. "Who would come after the chieftains? I couldn't see that; what I did see was the chieftains' estates crumbling to

\footnotetext{
${ }^{243}$ Painting taken from Wang Weizheng's website: http://wangweizheng.artron.net/main.php?pFlag=exhibi\&aid=A0005885 (accessed 2 August 2010).

${ }^{244}$ Bobao yishu wang 博宝艺术网, "'Fei tian di yi tu" Changzheng wanli tu 18 ri zai Chengdu paimai “飞天第一图” 《长征万里图》18 日在成都拍卖 " http://news.artxun.com/bimo-483-2414565.shtml. (accessed 2 Aug. 10).

245 "When the Dust Settles" is my translation of the Chinese title. The novel has been translated into English by Howard Goldblatt and Sylvia Li-chun Lin with the title Red Poppies.
} 
dust, leaving nothing behind after the dust settled. ${ }^{\text {246 }}$ This appears to be a good thing. The world of the chieftains' estates, as imagined by the novel, is a nasty one, where torture and other forms of abuse are commonplace. However, the real force behind the coming transformation is not a political revolution but the transition to a market economy.

Guomindang and Communist soldiers make brief appearances in the story for apparently no other reason than to give a token nod to the idea of change through political revolution. The "White Han" play their part by looking down on the Tibetans and inciting ethnic conflict. The "Red Han", a righteous "army of the poor" appear destined for something more positive and substantial, though there are hints that they may not be entirely good news either. ${ }^{247}$ "And if the Red Han won the civil war, I heard that they wanted even more to stain every piece of land in that colour they revered.” ${ }^{248}$ The omens are not too ill though. Whatever the coloured Han armies do, they will only be a temporary curtain-raiser for what the book suggests is the main historical transformation to come: the development of the open, market economy. A large part of the book focuses on the protagonist's establishment of a marketplace on the border of his father's territory. When his puzzled, commercially illiterate father asks him what it is, the narrator responds:

I told [my father] that the border town was not his summer palace, that it belonged to a future no one could see clearly. In that future all the estates would be gone and this would be a new place, one that would grow bigger and more beautiful, belonging to an age without chieftains. ${ }^{249}$

Despite a brief acknowledgement of the political revolution, Alai is telling his readers that the true revolutionary force is the marketplace.

\footnotetext{
${ }^{246}$ Alai, Red Poppies, trans. Howard Goldblatt and Sylvia Li-chun Lin (Boston: Houghton Mifflin, 2002), 373-74.

${ }^{247}$ Ibid., 411-12, 28.

${ }^{248}$ Ibid., 392.

${ }^{249}$ Ibid., 376.
} 
A 2006 article on Danba in the Chinese National Geographic (Zhongguo guojia dili 中国国家地理) by journalist Yu Jian 于坚 is similar. Like Alai's Kham, Yu's Danba is on the cusp of a great transformation that is economic rather than political in nature. Writing about Danba in 2006 and promoting the same thesis, $\mathrm{Yu}$ has the choice of either dealing with the political revolution and then proposing that economic change has been (or will be) more significant, or ignoring political change completely. He opts for the latter approach. “As far as every historical modernization movement went, the Southwest native region was either too late or completely missed out.”250 The reader gets the impression that the “old world” (gu dai 古代) persisted throughout the twentieth century.

Only at the very end of the twentieth century, when modernization had already become the mainstream of the nation's life, and the diversity of the Chinese traditional world was steadily disappearing under the standardization of modernism, did people suddenly discover that in a few places in China's west, always considered backwards and isolated, the spirit, life and culture of the old world had still preserved some of its startling innocence, richness and simplicity. ${ }^{251}$

Without the political revolution of socialism, there is only the commercial revolution prophesied by Alai. For Yu this great transformation is led by tourism and threatens to occur only at "the very end of the twentieth century”. In contrast to Alai, who views the coming transformation as essentially a good thing, $\mathrm{Yu}$ is more circumspect. He worries about the potential impact of modernization on traditional Tibetan life, and muses that 'backwardness' does not have to be a negative thing. ${ }^{252}$ A Han writer like $\mathrm{Yu}$ might have more freedom to wonder about the drawbacks of transformation than Tibetans like Alai. Alternatively, Alai, who is also editor of the Chengdu-based Science Fiction World (Kehuan

\footnotetext{
${ }^{250} \mathrm{Yu}$ Jian 于坚, "Danba: Hengduan shan zhong de lishi huohuashi 丹巴: 横断山中的历 史活化石," Zhongguo guojia dili 中国国家地理, Dec. 2006, 141.

${ }^{251}$ Ibid., 140-41.

${ }^{252}$ Ibid., 149.
} 
shijie 科幻世界) magazine, is perhaps genuinely less attached to romantic vision of vanishing simplicity-and-spirituality.

In the Communist era, the terms "tonghua" and "Hanhua" used in reference to the minorities became somewhat politically incorrect, though they continue to be used in unofficial discourse. One of the most common terms replacing them in formal language is ronghe 融合 (melding, integration), which signals more of a gradual, benign “melting pot” idea (though policy created to achieve this aim was not necessarily more benign). Rather than change wrought by bold, patriotic leaders and pioneers, the term suggests an impersonal process, in which politics is hidden. Ronghe is a key concept in Images of Xikang, and is virtually the only form of historical transformation depicted by the book. "Ronghe" occurs throughout the text in instances like the following comment on a picture of a Provincial Tibetan Primary School: “[The students] are all wearing long Chinese gowns, which one could see as an example of the ronghe of Tibetan and Han peoples.”253 To their credit, the editors recognize that ronghe also involved the Khamization of Han people as well. ${ }^{254}$

However, while this book demonstrates the power of the idea of “melding” in the present day, many other contemporary representations of minority and ethnically-mixed communities are eager to qualify acculturation, and stress that, despite appearances, cross-cultural influence has been rather limited. Yu Jian writes: "Even people in the most remote valleys can communicate in Chinese, but this has definitely not influenced the Bon faith that is the original religion of these mountains.” ${ }^{255} \mathrm{Yu}$ qualifies the effects of inter-ethnic relationships in the same way: "in terms of the blood (xueyuan 血缘) of its people, this region was one of the most mixed (hunza 混杂) in China, but also the most pure (chuncui 纯粹).”256

\footnotetext{
${ }^{253}$ Zhang Ming and Sun Mingjing, 1939 nian, 79.

${ }^{254}$ Ibid., 87.

${ }^{255}$ Yu Jian, "Danba: Hengduan shan zhong de lishi huohuashi," 142.

${ }^{256}$ Ibid., 140.
} 
This ostensibly meaningless statement suggests a need to see past ronghe and envisage non-Han communities as existing in some kind of pure form, uninfluenced by the outside world. This amounts to a strong denial of the historical significance of ronghe.

A couple of related factors are responsible for this. Firstly, whatever one calls it, the cultural integration of non-Han and Han is easily the most controversial form of frontier transformation. Minority elites, who had been nurtured in the nation's Minzu (Nationality) universities since the 1950s, have been active in resisting the notion that their people should or will inevitably assimilate into the Han majority. As Stevan Harrell and $\mathrm{Li}$ Yongxiang note: “[minority historians] are, in a very political sense, writing culture against culture, constructing a new version of China in which they are no longer just the bit players or the afterthoughts." ${ }^{257}$ Discussing what he calls the New Yi History (or the Yi Culture School), Harrell observes that: "the greatest motivator is cultural and ethnic pride"; its aim is to say: "Enough of insults, enough of relegation to the sidelines and the footnotes; for themselves at least and for anyone else who will listen, the Yi will assert their worth." 258

In the southwest, many minority communities have become significantly involved with tourism. This certainly includes Danba, named by the Chinese National Geographic, as one of the "six most beautiful old townships ( $g u$ zhen 古镇)” in China. As Tim Oakes has observed in Guizhou, minority villages that become tourist destinations often downplay or discourage signs of Han influence in order to satisfy tourists that they are, indeed, the authentic repositories of the mysterious minority cultures that tourists expect. One villager commented in an interview with Oakes that:

We wear our traditional Miao clothes, the embroidery, the long robes. We don't wear Han clothes when receiving guests. All the clothes are hand made, hand dyed; we grow the cotton ourselves, spin the thread. We build these traditional houses. [...] All the foreigners who come are happy, they like our clothing very much. I know. They tell me. We play

\footnotetext{
${ }^{257}$ Stevan Harrell and Yongxiang Li, "The History of the Yi, Part II," Modern China 29, no. 3 (2003): 364.

${ }^{258}$ Ibid.: 385-86.
} 
the lusheng; the Han play the erhu. We use different rhythms and sounds with our drumming than the Han, different dances. It's our tradition; we've always been different from the Han. [...] We're the true Miao (women zhen Miao 我们真苗)” he said. “We don't celebrate Spring Festival or any other Han festival. Zhouxi has its lusheng meeting during Spring Festival because they're not true Miao; they've been Hanified (Hanhuale 汉化了). Here, we only celebrate true Miao festivals, such as chixinjie, popojie, Miaonian, and jizujie, the grandest of them all. ${ }^{259}$

In the mindset of a tourist desiring to experience minority culture, the less the group in question has been influenced by Han culture, the more 'authentic' they are. The speaker above specifically mentions foreign tourists, but Chinese tourists also expect a slice of Otherness, unmodified (at least in certain superficial ways) by the culture they left at home. For such communities there is a commercial motivation for people to neglect histories of contact and integration, and focus instead on timeless traditions and civilizational essences.

Finally, the state itself has moved away from the idea that identity is flexible. Discussion of cultural change and the notion of increasing Han influence on the minorities are still very much alive. But official discourse no longer believes in the possibility of a person changing ethnic identities, or that there is such a thing as mixed identity. Ren Naiqiang's "Creole" hunzazu 混雜族 category has no equivalent in contemporary official research, or much traction within popular culture either. ${ }^{260}$ Nor do the notions of “cooked” (shu 熟) and “raw” (sheng 生) ethnic-other. Imperialistic though these categories were, they conveyed the idea that identity is flexible, and that people may be orientated at a certain point along a spectrum (in this case Han/civilized to non-Han/uncivilized), rather than in mutually exclusive blocs (like Han or Tibetan).

\footnotetext{
${ }^{259}$ Tim Oakes, Tourism and Modernity in China (London; New York: Routledge, 1998), 200-01.

${ }^{260}$ Ren Naiqiang, "Kangding xian shicha baogao," 262.
} 


\section{Conclusion}

This chapter has examined the twentieth century life of certain key ideas about change in frontier society, and in a couple of cases their death as well. We have seen that throughout the century, the politicized settler has been an important topic of discourse, and has been surrounded by the recurring patterns of representation. According to many representations, the zhiqing of the Mao era lived the dream of Republican era leaders who called for a generation of tough, capable and patriotic pioneers. But throughout the twentieth century there has also been considerable suspicion directed at migrants. In addition to being the heroes who tamed the frontier wilderness, they have been seen as the trouble-makers who made the frontier wild. In the revolutionary political traditions, no lesser volume of suspicion has been directed at frontier governors. Liu Wenhui, the Guomindang and the Communist party all blamed Han misrule for frontier conflict, and called for

a moral reformation of government that would inspire virtue and loyalty from the population. The idea of de hua has remained important in some narratives of history. But with the end of the revolution, or more accurately, the rise of non-revolutionary politics, narratives of history have tended to downplay or completely omit the story of a great political transition. Instead they have focused on some species of modernization-either technoinfrastructural or economic — as the key driver of change in the highlands.

The most controversial form of change has been the "assimilation", or in milder, more politically correct language, the "melding” of ethnic groups. Yet whatever term is used, leaders have found it difficult to articulate a clear conceptualization of what this would really mean. Zhao Erfeng, who did not use the term tonghua very much, attempted to make the Tibetans adopt certain aspects of Han culture, primarily because he believed in the superiority of those cultural practices. By adopting them, Tibetan society would be stronger, richer, less susceptible to foreign imperialism and more able to support the superior form of administration that Zhao wanted to establish. For Liu Wenhui, assimilation was, in the first order, a response to the problem of a division between Han and non-Han that created conflict, rather than a response to the backwardness of non-Han culture. To a certain 
extent Liu's idea of “progress”, jin hua, echoed Zhao Erfeng's cultural policies, though it was the least clearly articulated of all Liu's "three transformations”. This is not to say that Liu was always an altogether milder and more tolerant leader than Zhao. The Yi (if not the Tibetans) would have to give up being $\mathrm{Yi}$ in order for the conflict between $\mathrm{Yi}$ and Han to end completely. Like the idea of a moral transformation of politics, the notion of ethnic integration is to this day at the heart of some understandings of what has happened in recent history. Yet in others it is only just about to happen; or, indeed, may never occur. 


\section{Conclusion}

To tie together the arguments presented in the chapters of this thesis, I pose several broad questions about the nature and causes of transformation in the Sichuan frontier. Firstly, in what sense did Zhao Erfeng and Liu Wenhui aim to sinicize the highlands? Secondly, in what ways and to what extent did parts of Kham and Liangshan become more similar to other parts of China in the first half of the twentieth century? Thirdly, to what extent was the environment a key factor that shaped the course of events? Fourthly when were the key moments of transition; and, fifthly, what factors best explain them?

\section{Chinese Highlands?}

The photographer Zhuang Xueben 庄學本 (1909-1984), who is justly famous for the photos he took in the Xikang region in the 1930s, commented that "the scenery at Bathang is as beautiful as that in Jiangnan, and because of this the town is known as "Suzhou beyond the pass"”. ${ }^{1}$ And in the accounts of most historians, the aim of Zhao Erfeng and Liu Wenhui was precisely to transform the highlands west of the Sichuan basin into something that was as similar as possible to an idealized world of Han civilization of which Suzhou is so emblematic. Yet any view that they merely aspired to recreate a proto-typical "Han society" in the highlands is incomplete.

In Zhao Erfeng's vision, the indigenous people would learn Chinese, stop polyandrous marriage, adopt the Qing regulation hairstyle and replace sky burial with Han burial customs. ${ }^{2}$ However, his plan for settlement was

\footnotetext{
${ }^{1}$ Ma Naihui 马罪辉, Wang Zhaowu 王昭武, and Zhuang Wenjun 庄文骏, eds., Chenfeng de lishi shunjian: sheying dashi Zhuang Xueben 20 shiji 30 niandai de xibu renwen tanfang 尘封的历史瞬间: 摄影大师庄学本 20 世纪 30 年代的西部人文探访 (Chengdu: Sichuan minzu chubanshe,2005), 245.

${ }^{2}$ QCBD, 1:95-103.
} 
firmly within the tradition of the state agricultural colony (tun 屯) and did not constitute a vision for the recreation of Han society as it actually existed anywhere in the interior. Settlements would be state controlled communities in which land was parcelled out to civilian or soldier farmers who had perpetual use-rights, but no right to sell or buy land. Settlers would work their own plots and have a direct relationship with the state bureaucracy so there would be no landlord class. Zhao's Kham administration directed migrants toward particular locations, and prohibited them from going to others or freely engaging in pursuits such as digging medicines. Such a society would be fundamentally different from that which existed in the lands within the traditional sphere of Chinese civilization. It was a vision informed by several factors. In addition to Zhao's priorities as a military leader, there was the influence of the late imperial Chinese statecraft belief that expanding cultivation was the best way of increasing wealth. Also important was the greater degree of scepticism Zhao held regarding the potential of the Kham environment than some of his memorials let on.

Liu Wenhui's policy did not reveal the same urge to control migration or shape frontier society according to a particular ideological vision, but neither did he show Zhao's eagerness to import Han culture. Liu wrote contradictory things about "assimilation" and whether or not "Using Chinese Civilization to transform the barbarian” was a good thing. But in general, his discussion of assimilation tended to focus more on the need to break down the boundary between the Han and non-Han worlds than on problematizing culture on the non-Han side of the boundary, which was at the core of Zhao's culture policies. Liu articulated a go-slow approach to change in indigenous society: "If the existing order is completely overturned, it will be very difficult for the new order to succeed it". ${ }^{3}$ There were no regulation hair-styles or proscribed burial practices under his rule, and he patronized indigenous Buddhist tradition, albeit within what were in theory highly controlled institutional environments. The cultural policies of the Liu Wenhui-era were more like those of the 1980s than the 1900s or the Mao era.

\footnotetext{
${ }^{3} J K D Z, 52$.
} 
These caveats aside, to what extent did the highlands in the west and southwest of Sichuan become more similar to and integrated within the Han Chinese world in the first half of the twentieth century? There was an increase in the Han population in Kangding and Luding, and small Han communities grew in various places further west. In Liangshan, there were more Han people in Yuesui at the end of the Republican period than there had been at the beginning of the twentieth century. In other parts of Liangshan, however, such as Zhaojue and Leibo there were less. The evidence indicates that one of the major demographic trends in Ningshu was increasing ethnic segregation. Ethnically mixed people and organizations still existed; examples are 'Electric' Leng and Deng Xiuting, who was usually identified as Han but could speak Yi and allegedly had "Yi blood in his veins". ${ }^{4}$ Nevertheless, the intense conflict that broke out in many places in the late 1910s made it more difficult to venture into the territory of the ethnic other. Han and Yi abandoned land on the edges of their settlements, creating a huang no-man's-land in between increasingly estranged communities. Thus from a demographic perspective, a few places in Kham became somewhat more similar to Han China, and some of Ningshu's "Han territories" probably became more homogeneously Han. But the Han presence in many parts of Liangshan dwindled.

In its basic form, local government in some communities in Kham and Ningshu became more similar to that in interior China. In last five years of the Qing, the Zhao brothers established county governments and Chinese schools across Kham and in some parts of Liangshan. Their fate in the Republican period was mixed. Some county authorities effectively disappeared for the entire Republican era. Anthropologist Li Shaoming described the situation in Zhaojue: “The county governor of Zhaojue didn't dare live there; he stayed in Xichang. Zhaojue's county government existed in name only; in reality it didn’t do anything." ${ }^{5}$ The same comment could be made of places like Derge or Sershul in Kham. In other places, Han-

\footnotetext{
${ }^{4}$ Zeng Zhaolun, Da Liang Shan Yi qu kao cha ji, 41; "Ningshu diaocha baogao huibian", junshi men, 59; zhengsu men, 27.

${ }^{5}$ Li Shaoming 李绍明, "Sichuan minzu diqu minzhu gaige de lishi huigu 四川民族地区民 主改革的历史回顾," Xinan Minzu Daxue xuebao (renwen sheke ban), Jan. 2008, 36.
} 
dominated regional and local state institutions experienced a decade of weakness, though often not complete collapse, from the late 1910s, when the occupation of Sichuan by the Yunnanese army led to budget cuts in frontier defence and a re-focusing of efforts away from the frontier. Handominated state authorities began to recover from the mid-1920s under the reign of Liu Wenhui. Even after losing the Sichuan basin to Liu Xiang's forces in 1933, the rump of Liu Wenhui's Twenty Fourth Army still had the capacity to disarm militias in Ningshu and defeat the well-armed Panchen Lama's field office in distant Kanze. In the 1940s, in places such as Drango and Nyarong there was a balance of power between Han magistrates and indigenous authorities. Around Kangding, Dawu and Yuesui, Han authority was more robust. At the end of the Republican period, Barnett thought Liu's forces compared favourably to other armed forces in China. The relative success of Han dominated institutions in these parts has not been highlighted by much of the existing literature because it was so much more limited than what officials had hoped for. Yet in these places Han governors were more important than they had ever been before, and this degree of authority achieved at a time of civil war and, between 1937 and 1945, Japanese occupation of the east of China.

However, Han-dominated county and regional government authority did not herald a trend toward the end of regional diversity and the incorporation of territories into an undifferentiated Han political system. While county and regional governments, the Twenty Fourth Army and organizations such as the Agricultural Institute were based on templates taken from Interior China, the policies created by these bodies, and their relationships with other elements of society, were thoroughly shaped by local environments and older institutions. Chapter four showed the influence of the wula corvée labour tax on politics in Kham. The problems created by the tax led one coalition of officials to argue for the creation of a stateowned organization that would provide pack-animals for government and military transport. There were two attempts at establishing such an institution, but both failed, probably because they were under-resourced. Nevertheless, efforts in this area had an important impact on the Kham landscape because they led to the establishment of an enormous ranch which 
continued to exist even after the transport organizations were wound up. Other officials, those who were more suspicious of state-enterprise and less convinced of the need to circumvent indigenous leadership argued for the corveé to be retained but ameliorated with regulation. This approach required a deeper engagement with indigenous leadership and communities than would have been necessary had the efforts to establish an alternative transport institution been successful. It also meant that the development of governing institutions in Kham followed a different path from that in northern China. There, according to Prasenjit Duara, formal government proliferated together with an extraneous layer of leadership that performed tax collection services for the government but was not under its control. In Kham, the amount of corvée labour that could be extracted from roadside households was often too limited for distinct and non-integrated authorities to grow simultaneously without cannibalizing each other. In some cases, this led to conflict between corvée-levying authorities, and in other cases, it led to a minute division of the tax base between them

Chapter five demonstrated that Ninshu was different again. Here the key problem was neither the lack of corvée labour (as in Kham) nor the proliferation of go-betweens in the space separating the formal government and villages (as in northern China), but on the contrary the severing of ties between local government and a class of go-betweens. Since the Tongzhi reign (1861-1875) Han governments recruited Yi mercenaries to keep the peace on the ethnic frontier zone. Like Duara's entrepreneurial brokers, these Yi security contractors existed largely outside the control of the governments they served, though they were required to send leaders to specially designated "Yi guardhouses" as security. This system collapsed around 1917 when the Han local garrison commanders ran out of money to pay them, probably because the Yunnanese occupiers of Sichuan withheld funds from the Sichuanese military. The sudden unemployment of significant numbers of mercenaries precipitated the bloody conflict that Han sources called the "Yi scourge". By the mid-1920s relative peace and stability had broken out in most places, though tension and sporadic fighting continued and exercised a powerful influence on Ningshu's political environment for the rest of the Republican period. The redevelopment of 
leadership in the social space between Han governments and $\mathrm{Yi}$ communities was a cause of increasing stability rather than state involution leading to the impoverishment of villagers. So while the old frontier order in Kham and Ningshu underwent considerable change, and in many ways the regions did become more integrated with external political structures, local factors continued to play a decisive role in determining the nature and agendas of local government.

\section{The Extent of the Influence of the Environment}

There is a temptation to highlight the impact of the environment, particularly on the events in Kham. Climate obviously determines the limits of agricultural settlement, but this dissertation has also highlighted the effects of the high cost of transport imposed by mountainous terrain. The amount of genuinely free arable land in the highlands at the beginning of the twentieth century is difficult to calculate with the sources used by this study. But even if there had been a lot of unused arable land, enormous transport costs made crop farming on land more than a couple of days journey from a major market a less profitable activity than carrying goods for merchants who trafficked tea to the Tibetan lands, and musk and medicine back east.

In The Art of Not Being Governed, James C. Scott puts geography and its effect on transport at the heart of his thesis, arguing that topographical difficulty prevented the establishment of effective state power in highland Southeast Asia before the development of a raft of technologies such as allweather roads and flying machines. ${ }^{6}$ In some respects, the history of Xikang appears to support his thesis. After all, Han-dominated governing institutions only controlled a small part of the territory within Xikang province. Even there, Han authority required big subsidies from the national government, as well as, in Liu Wenhui's case, the historical accident that the region could produce a commodity that lowlanders wanted but were

\footnotetext{
${ }^{6}$ James C. Scott, The Art of Not Being Governed: An Anarchist History of Upland Southeast Asia (New Haven: Yale University Press, 2009), 11.
} 
prohibited from manufacturing. Transport was not such a critical problem in Liangshan, but mountains still inhibited Han government power. Many discussions of military campaigns against the "Yi scourge" mention the difficulties caused by the terrain for armies sent to battle the $\mathrm{Yi}^{7}$

To overcome the logistical problems posed by mountainous terrain, most pre-oil age imperial polities adopted corveé labour systems when they moved into highland territory. This was characteristic of the Qing and other post-Mongol empires in central Asia, the Spanish in the Andes and the British in the southern Himalaya and Kashmir. ${ }^{8}$ In all these regions, imperial state-building ambitions put great pressure on the highlanders who performed the corveé, to an extent that could ultimately undermine imperial economic goals. At precisely the same time as Zhao Erfeng declared that there would be no wula without payment in Kham, British officials made similar pronouncements in Uttarakhand and Kashmir. ${ }^{9}$ As in Kham, however, repeated attempts at regulation failed to prevent officials' continued conscription of labour for transport at levels that caused significant hardship in mountain communities. ${ }^{10}$

Yet topography did not determine everything. This much has already been shown by the way that officials in Kham came up with different solutions for the wula problem, each with distinct implications for the further development of Chinese authority in the highlands. Developments in the British Himalaya and foothills were also quite different from in Kham. In the southern Himalaya, opposition to the British use of corveé (called begar and utar) was widespread, well organized and came at the same time as Gandhi's non-cooperation movement. There were more than 146 anti-

\footnotetext{
${ }^{7}$ Yang Minghong, "Lun Qingdai Liangshan Yi qu de tusi zhidu yu gaituguiliu," 94.

${ }^{8}$ For the British use of corveé labour in the Himalaya, see: Shekhar Pathak, "The Begar Abolition Movements in British Kumaun," Indian Economic Social History Review, no. 28 (1991): 261-62; Kenneth Iain MacDonald, "Push and Shove: Spatial History and the Construction of a Portering Economy in Northern Pakistan," Comparative Studies in Society and History 40, no. 2 (1998): 292.

${ }^{9}$ Pathak, "The Begar Abolition Movements," 265.

${ }^{10}$ Ibid., MacDonald, "Push and Shove," 293.
} 
begar meetings in Uttarakhand in the first four months of $1921 .^{11}$ There were also differences between the British and Chinese administrations: the Commissioner for Kumaun (one of the two sub-regions of Uttarakhand) saw the territory that he was in charge of as (in Pathak's paraphrasing) “a small, hot part of a vast country." 12 I have not encountered a record of a Chinese regional government official in Kham saying anything comparable. Perhaps the latter were too far removed from the Chinese central government to adopt such a perspective, or perhaps they were more wedded to a view of Kham as a key strategic region on the route to Tibet. The British repression of protest against begar was harsh, but in 1921 provincial officials calculated that it was not worth continuing the fight for their right to corveé labour for transport in a territory they themselves viewed as not particularly important. In that year, begar was abolished and in the following year the government of India spent more than 160,000 rupees on hiring porters for officials travelling in the hills. ${ }^{13}$ Hence, throughout the fringes of the Himalaya the environment gave rise to a set of common problems, and there were some similarities in the processes by which lowland-based governments extended their authority in the highlands. But the final outcomes depended on local political and institutional contexts.

\section{Innovation in Governance}

When did the key moments of political innovation occur in the Sichuan frontier and what sparked them? As we saw in chapter two, some historians have argued that there was something inherently modern about Zhao Erfeng's vision for the future of the frontier. Zhao certainly aimed to transform the highlands, but there was little in his planning or action that was really outside Qing precedent. The removal of local leaders who upset

\footnotetext{
${ }^{11}$ Ramachandra Guha, The Unquiet Woods: Ecological Change and Peasant Resistance in the Himalaya (Oxford: Oxford University Press, 2000), 112.

${ }^{12}$ Pathak, "The Begar Abolition Movements," 267.

${ }^{13}$ Guha, The Unquiet Woods, 112.
} 
the court or rebelled against its plans; the establishment of agricultural colonies and schools; payment for conscripted labour; and the use of foreign technology; these were all things that frontier governors of the eighteenth century had done as well. The view that Zhao's aspirations were fundamentally modern can be sustained only if we are willing to see modernity within aspects of the early and high Qing traditions of governance on which he mostly drew.

This has become a relatively common notion within China scholarship, though as Zhang Yongle has observed with reference to Wang Hui's 王 暉 The Rise of Modern Chinese Thought (Xiandai Zhongguo sixiang de xingqi 现代中国思想的兴起):

The modernity or 'early modernity' he seeks in Chinese history is an open possibility rather than a structured project. The only thing we know about its meaning is that it involves the emergence of new pathways, not the replication of any version of modernity confected in the West. ${ }^{14}$

This prompts Zhang to wonder whether there is "any further content left to the term 'modern'?”15 In Zhang's view, Wang Hui uses the term “modern” primarily as an expedient, so that Western readers are not tempted to regard the China of his work as "traditional". If this is indeed the primary reason for retaining the term "modern", it is doubtful whether twenty-first century scholarship will be as captivated by the concept as twentieth century historiography was.

In any case, there is no indication that Zhao saw himself as a political innovator or made any claims to have devised new modes of frontier governance. There is nothing in Zhao's writing comparable to Liu Wenhui's remark that the Three Transformations policy was a "new policy for the government of the frontier peoples (bianmin 邊民) [...] different from all previous policies.” ${ }^{16}$ A lot of what Liu described in his introduction to the

\footnotetext{
${ }^{14}$ Zhang Yongle, "The Future of the Past: On Wang Hui's Rise of Modern Chinese Thought," New Left Review, no. 62 (2010): 54.

${ }^{15}$ Ibid.

${ }^{16}$ Liu Wenhui, "Jianshe xin Xikang shi jiang," 597.
} 
Three Transformations Policy was really just an old-fashioned concern for demonstrating virtuous rule, influenced by his reading of Ming chivalric novels and combined with an acknowledgement that Zhuge Liang-esque enfeoffment of duly submissive native leaders would not do in an era that demanded the integration of the border peoples into a united Chinese citizenry. De hua and tonghua together was an awkward and arguably somewhat unusual combination, but Liu did not invent either of these concepts any more than Zhao discovered the idea of getting rid of tusi and establishing state agricultural settlements. Yet Liu clearly wished to be seen as an innovator in the field of frontier governance in a way that was not important for Zhao Erfeng.

Liu's claim to have discovered a new way of ruling the borderlands is also at odds with much scholarship that suggests that the Republican and Socialist periods were not eras of enduring innovation in the actual practice of frontier governance. James Millward suggests the core aim and elements of migration policy to Xinjiang in the early years of the People's Republic were not very different from during the Qianlong reign. ${ }^{17}$ Thomas Cliff adds that the great changes to the institution of the military-agricultural colony, “more dramatic than any [...] in its 2,200-year history”, occurred in the 1990s and 2000s. ${ }^{18}$

However, while Liu Wenhui overstated the novelty of the "Three Transformations", there were a couple of genuine breaks with tradition under his rule. State-owned corporate organizations became the key units for highland agricultural development in the 1930s. This was an important move away from the Qing model of settlement. Qing tun colonies varied in the degree to which they aimed to restrict the movement and activity of their inhabitants, and as noted above Zhao intended the Kham administration to exercise a high degree of control over the settlements that he founded in the highlands. Nonetheless, migrants in the Qing era had permanent rights to specific plots of land that they managed independently as tenant-farmers. In

\footnotetext{
${ }^{17}$ Millward, Eurasian Crossroads, 251.

18 Thomas Matthew James Cliff, "Neo Oasis: The Xinjiang Bingtuan in the Twenty-first Century," Asian Studies Review 33, no. 1 (2009): 103.
} 
the Republican period, settlement by tun gave way to settlement by stateowned enterprises that hired waged labour and were managed by an Agriculture Institute that was directed by technocrats, two of whom had agronomy qualifications from foreign universities. It may be that, with closer examination and comparison, Republican era innovation may reveal itself to be just as significant as that of the post-Mao reform era, if not more so.

Yet another major change of the Republican period actually limited the development of most state-owned agricultural enterprises. Apart from the Taining ranch, the state farms operated by the Agriculture Institute rented land from private landlords, even when the land was listed as "wasteland", which in theory belonged to the government. Liu regime's respect for landlords' property in this instance was probably related to the growing importance of the deed tax, which gave local government an incentive to issue title to huang land. The rising significance of taxes on livestock also made it less reasonable for local governments to see uncultivated land as, prima facie, unproductive. Republican period tax innovation aimed to increase government revenue in order to expand the capacity of government at all levels. Thus two innovations in government practice, both apparently aimed at enlarging government, nevertheless pulled in different directions. The new revenue systems meant that local-government decision making could work against the development of the new agricultural development strategy. This serves as a warning against seeing an overall coherence, or patterns of mutual-reinforcement, within historical development, even when the source of such developments is connected.

After 1949, the deployment of air-power and fleets of trucks radically altered local political contexts, but much remained the same in the field of culture production. Han migrants continued to be represented as both worldbuilding pioneers and hooligans. The idea of a moral transformation in politics leading to a transformation of society continued to be articulated. Despite this, doubts remained as to whether virtuous rule was really historically relevant or not, though the source of the doubt changed from concern about whether or not the Yi responded to virtue, to an unstated disaffection from the idea of political transformation. Something like 
“assimilation” or “integration” remains of utmost importance for many commentators, though there are continued doubts about the nature and outcome of the process.

One of the questions identified at the beginning of this thesis was whether global, regional or local (clearly these are not categories that have natural definitions, but they are useful as heuristics) factors tell us more about why the changes outlined throughout have occurred. The new political calculus brought on by the arrival of combustion engines, not examined in this thesis but foreshadowed clearly enough, is one instance in which the transformation of the Sichuan frontier was a local manifestation of a global pattern of change caused by a revolution in transport technology. Aside from this, I do not generally find it persuasive to argue that events should be understood primarily as part of global developments, or responses to stimuli outside China. The danger of a British annexation of Tibet was a spur to action, but one that strengthened a pre-existing argument for imposing the administrative system of Han society in the non-Han southwest. The revolts against Chinese authority in 1905 appear to be a better explanation for Zhao's campaigns than arrival of the British in Tibet, to which Xiliang's initial response was rather weak. Moreover, the British invasion of Tibet cannot explain moves to remove tusi from Liangshan. As noted above, Zhao was more influenced by Chinese traditions of frontier governance than Western imperialism, though there were resemblances between the two that were the result of different administrations facing similar problems.

Yet the events in the southwest in the 1900s clearly do belong to a larger pattern of change. From the 1880s, the Qing court moved to establish the Chinese administrative system, settler colonies and elements of Han culture in all the territories that had previously been conceptualized as separate and distinct components of the empire from the Han lands. Why this shift occurred is not well understood. Gong Zizhen 龍自珍 (1792-1841) argued in an 1820 essay that the sinicization of Xinjiang was an investment that would end the region's dependence on subsidies and even allow it to 
"give up wealth to benefit the centre". ${ }^{19}$ But it seems unlikely that the reforms that came to all frontiers at the end of the dynasty were really motivated above all by a rational calculation of what was in the empire's best economic interests. For, though Li Hongzhang 李鴻章 (1823-1901) famously (and thus far accurately) predicted that Xinjiang would never be other than a drain on the centre's finances, there was not as much analysis of economic costs and benefits as one would expect if this had really been at the heart of court decision making.

Wang Hui argues that Gong Zizhen's conceptualization of "China” eliminated the Great Wall as a natural boundary between Chinese civilization (Xia 夏) and the exterior world of the Barbarian ( $Y i$ 夷). ${ }^{20}$ Wang suggests that this conceptual move was due to a group of statecraft thinkers' promotion of the idea of the empire as a Great Unity (da yi tong 大一統) based on (Confucian) protocols (liyi 禮儀), rather than a polity segmented on the basis of a set of racial identities. ${ }^{21}$ This served as a subtle critique of Manchu ethnic segregation and privilege that disadvantaged the Han scholars. If Gong Zizhen's argument for the provincialization of the territory beyond the Great Wall was related to a view of the empire that developed as a response to the disadvantaged position of Han literati under Manchu rule, then it is possible to imagine the provincialization of Xinjiang and Tibet occurring without the arrival of the Europeans. The onset of European imperialism in Asia may still have acted to speed up the process and convinced doubters of the value of acting, but the powerful internal dynamic cannot be ignored.

The move towards state-owned enterprises in the Republican era was certainly not confined to Xikang either. Morris L. Bian has traced the origins of the Chinese state-owned enterprise system to the 1930s, arguing that crisis sparked by the Japanese invasion led to the transformation of the

\footnotetext{
${ }^{19}$ Quoted in Millward, Beyond the Pass, 241.

${ }^{20}$ Wang Hui, Xiandai Zhongguo sixiang de xingqi, shang juan, di er bu: diguo yu guojia, 603.

${ }^{21}$ Ibid., 570.
} 
"mental models of institutional environments". ${ }^{22}$ This process entailed the development of new organizational forms, including the danwei 單位 ("work unit"), which became central to the socialist reorganization of Chinese society. This case is well argued, though the influence of the Japanese invasion on events in Xikang should not be overdrawn. Of all the province's state-owned agricultural enterprises, the Taining ranch was the largest and had the most enduring impact, and this was because of local factors unrelated to the Japanese.

The tax innovations of local and regional Han governments in the Republican period came from a financial tool-kit used by authorities throughout China as they attempted to build capacity and undertake more and different kinds of work. To this extent, here too the Han authorities in the highlands followed a broader pattern of change that unfolded across the country. Yet as Elizabeth Remick has shown with reference to Hebei and Guangdong, different authorities favoured different tools and used them differently, with divergent implications for the development of local government and its relationship to society. ${ }^{23}$ Whether or not there were other parts of China in which the rise of taxes on land title and livestock had an impact comparable to that in Xikang is a question worthy of future research.

The Han governors in the highlands were part of a broader world of Chinese politics and were affected by the major trends within that world. Yet the history of government in the highlands in the first half of the twentieth century is not a story of the 'state' as a discreet entity that was 'built' as part of a national mission, and which having been thus built, obtained an agency of its own. Rather this dissertation has shown how government officials' social roles-that is, what they did and how they related to the people around them-were shaped in the intersection of ideology (drawn from a diverse Chinese cultural milieu) with concrete and distinct local challenges that varied significantly between regions. For all

\footnotetext{
${ }^{22}$ Morris L. Bian, The Making of the State Enterprise System in Modern China: The Dynamics of Institutional Change (Cambridge, Mass.: Harvard University Press, 2005), 14.

${ }^{23}$ Elizabeth J. Remick, "The Significance of Variation in Local States," 408-09.
} 
that the likes of Zhao Erfeng had ideological preferences heralding from an evolving Qing tradition, in his own time and after, local officials' agendas were powerfully moulded by attempts to solve local problems. These included: how to raise more revenue from the society and ecology immediately around them; how to efficiently arrange for the transport of people and things from place to place; and how to deal with conflicts caused by the end of historical institutions and relationships. Given that such challenges varied significantly, it was not surprising that local governors' pronouncements on matters such as assimilation of the indigenous, moral governance and modernity were often at odds with one another and not always thoroughly thought out. 
Glossary of names for places and peoples

Alternative names and spellings for places in this thesis

\begin{tabular}{|c|c|c|c|}
\hline Current Chinese & Qing Chinese & $\begin{array}{l}\text { Republican } \\
\text { Chinese }\end{array}$ & $\begin{array}{l}\text { Romanizations of } \\
\text { Indigenous names }\end{array}$ \\
\hline $\begin{array}{l}\text { Liangshan Yi } \\
\text { Autonomous } \\
\text { Prefecture 凉山彝 } \\
\text { 族自治州 }\end{array}$ & $\begin{array}{l}\text { Ningyuan } \\
\text { Prefecture } \\
\text { 甯遠府 }\end{array}$ & $\begin{array}{l}\text { Ningshu 甯 } \\
\text { 屬 }\end{array}$ & n.a. \\
\hline Kangding 康定 & $\begin{array}{l}\text { Dajianlu } \\
\text { 打劍爐 }\end{array}$ & $\begin{array}{l}\text { Dajianlu } \\
\text { 打劍爐 }\end{array}$ & $\begin{array}{l}\text { Darstedo / } \\
\text { Dartsendo / } \\
\text { Dhartsendo }\end{array}$ \\
\hline Batang 巴塘 & $\begin{array}{l}\text { Batang / Baan 巴 } \\
\text { 安 }^{1}\end{array}$ & Baan 巴安 & Bathang \\
\hline Litang 理塘 & $\begin{array}{l}\text { Litang / Lihua 理 } \\
\text { 化 }\end{array}$ & Lihua 理化 & Lithang \\
\hline Ganzi 甘孜 & -- & -- & $\begin{array}{l}\text { Kanze / } \\
\text { Garzê / } \\
\text { Kandze }\end{array}$ \\
\hline Daofu 道孚 & -- & -- & Dawu \\
\hline Jiulong 九龙 & -- & -- & Gyaisi \\
\hline Dege 德格 & -- & - & Derge \\
\hline Changdu 昌都 & -- & -- & Chamdo \\
\hline Shiqu 石渠 & -- & -- & Sershul \\
\hline Xinlong 新龙 & $\begin{array}{l}\text { Zhandui 瞻對 / } \\
\text { Zhanhua 瞻化 }\end{array}$ & $\begin{array}{l}\text { Zhanhua 瞻 } \\
\text { 化 }\end{array}$ & Nyarong \\
\hline Luhuo 爐霍 & -- & -- & Drango \\
\hline Baiyu 白玉 & -- & -- & Pelyül \\
\hline Yuexi 越西 & $\begin{array}{l}\text { Yuesui 越㠎 } \\
\text { (some sources } \\
\text { give } \\
\text { pronunciation of } \\
\text { second character } \\
\text { as } x i \text {, others sui) }\end{array}$ & $\begin{array}{l}\text { Yuesui 越 } \\
\text { 嶉 }\end{array}$ & \\
\hline
\end{tabular}

${ }^{1}$ The Chinese names of Bathang and Lithang were changed by Zhao Erfeng 
$\underline{\text { Chinese language ethnonyms }}$

\begin{tabular}{|c|c|c|}
\hline Term & $\begin{array}{l}\text { Late Qing/ Republican } \\
\text { Period meanings }\end{array}$ & Current meaning. \\
\hline 夷 Yí & $\begin{array}{l}\text { (1) 'Non-Han’, somewhat } \\
\text { derogatory, often translated } \\
\text { as “Barbarian” in English. } \\
\text { In this sense, it included } \\
\text { people identified as "Kang”, } \\
\text { "Fan”. Also used to refer to } \\
\text { Europeans in the Qing } \\
\text { period. } \\
\text { (2) (More common in } \\
\text { Republican period). Chinese } \\
\text { language ethnonym for the } \\
\text { indigenous people in } \\
\text { Liangshan / Ning region. In } \\
\text { this sense, it excluded } \\
\text { groups such as the "Fan”, } \\
\text { "Kang”. Sources disagree as } \\
\text { to how derogatory Yi 夷 } \\
\text { was in this sense. }\end{array}$ & $\begin{array}{l}\text { Meaning (1) is obsolete, and } \\
\text { the notion of "Non-Han" is } \\
\text { covered by the referent } \\
\text { "minority ethnic group" } \\
\text { (shaoshu minzu 少数民族). } \\
\text { Meaning (2) is semi- } \\
\text { obsolete; the character was } \\
\text { changed in the 1950s to the } \\
\text { homophonous neutral and } \\
\text { non-connotative 撛 Yí (an } \\
\text { ancient term for a kind of } \\
\text { wine or sacrificial vessel, no } \\
\text { longer used in the modern } \\
\text { period). }\end{array}$ \\
\hline 蠻 Man & $\begin{array}{l}\text { (1) 'Non-Han', derogatory, } \\
\text { often translated as } \\
\text { “Barbarian”. Common in } \\
\text { Qing texts, but less so in the } \\
\text { Republican period. }\end{array}$ & Obsolete. \\
\hline 猓猓 Luoluo & $\begin{array}{l}\text { Insulting ethnonym for } \\
\text { indigenous people in } \\
\text { Liangshan / Ning region } \\
\text { (also called } Y i \text { 夷/彝). } \\
\text { Derives from self- } \\
\text { identification, but written } \\
\text { with insulting 'dog' radical } \\
\text { 犭. }\end{array}$ & Obsolete. \\
\hline
\end{tabular}

${ }^{2}$ Peter Goullart reported that an Yi person told him: “Although the Chinese call my people the Lolos, we dislike it intensely as it is a derogatory appellation and even its Chinese character carries an indicator which means "beast"; we may be savages, but nobody likes that to be said to his face [...] The proper name for us which we use is Yi” Goullart, Princes of the Black Bone, 117. Most Republican period Chinese sources use yi 夷, but a couple report that it was an insulting term; see: Xikang sheng canyihui 西康省參議會. "Linshi canyihui, di yi ci hui huibian 臨時參議會第一次會匯編," 1940, (SCDAG, QZH: 204, AJH: 14), section 8, 13b. 


\begin{tabular}{|c|c|c|}
\hline 倮倮 Luoluo & $\begin{array}{l}\text { Modified version of 猓猓, } \\
\text { written with 'human' } \\
\text { radical } \uparrow \text { rather than the } \\
\text { 'dog' radical } 犭 \text {. But still } \\
\text { said to be insulting. }\end{array}$ & Obsolete. \\
\hline 彝 $Y i ́$ & $\begin{array}{l}\text { (Not used in Qing or } \\
\text { Republic) }\end{array}$ & $\begin{array}{l}\text { Ethnonym for indigenous } \\
\text { people in Liangshan/Ning } \\
\text { region. Not insulting. }\end{array}$ \\
\hline 番、蕃 Fan & $\begin{array}{l}\text { (1) Used in the medieval } \\
\text { Chinese name for Tibet, } \\
\text { tufan 吐蕃 (sometimes said } \\
\text { to be pronounced tubo). Not } \\
\text { used as a contemporary } \\
\text { toponym during the period } \\
\text { of this study. } \\
\text { (2) Used as an ethnonym to } \\
\text { refer to Tibetans, similar to } \\
\text { modern usage of Zang 藏 as } \\
\text { an ethnonym. } \\
\text { (3) Used as an ethnonym to } \\
\text { refer to people in Kham } \\
\text { deemed to be non-Tibetan } \\
\text { but related to Tibetans, } \\
\text { often in the compound } \\
\text { Xifan 西番/蕃. Confusingly, } \\
\text { this translates as “West } \\
\text { Fan”, even though there are } \\
\text { no “East Fan” and they } \\
\text { people referred to by this } \\
\text { name live to the east of their } \\
\text { purported Tibetan relatives. }\end{array}$ & Obsolete. \\
\hline 康 Kang & $\begin{array}{l}\text { A transliteration of the } \\
\text { Tibetan place name } \\
\text { 'Kham'; the eastern part of } \\
\text { the Tibetan world. In } \\
\text { Republican period Chinese } \\
\text { discourse, Kang ren 康人, } \\
\text { "Kham people” was used as } \\
\text { an ethnonym for the natives } \\
\text { of Kham. }\end{array}$ & $\begin{array}{l}\text { Used informally, often in } \\
\text { compounds like Kang qu 康 } \\
\text { 区, “Kham region”; Kang } \\
\text { ba 康巴 (transliteration of } \\
\text { Tibetan Kham pa “Kham } \\
\text { person”. Kang ba is } \\
\text { sometimes mistakenly taken } \\
\text { to be a transliteration of a } \\
\text { geographic term, and used } \\
\text { as a 'native-ized' alternative } \\
\text { to Kang qu). Kang 康 does } \\
\text { not occur in the name of a } \\
\text { formally recognized ethnic } \\
\text { groups and, in } \\
\text { administrative place names, } \\
\text { only in Kangding 康定. }\end{array}$ \\
\hline
\end{tabular}




\begin{tabular}{|c|c|c|}
\hline 藏 Zang & $\begin{array}{l}\text { A transliteration of the } \\
\text { Tibetan place name } \\
\text { 'Tsang'; the region } \\
\text { encompassing Lhasa. In } \\
\text { late-Qing and Republican } \\
\text { Chinese Zang usually } \\
\text { referred only to people } \\
\text { living in what is now the } \\
\text { Tibetan Autonomous } \\
\text { Region (called "Central } \\
\text { Tibet” by Western } \\
\text { Tibetology). Thus it did not } \\
\text { refer to Kham natives. }\end{array}$ & $\begin{array}{l}\text { Used as an official } \\
\text { ethnonym in roughly the } \\
\text { same way as the English } \\
\text { “Tibetan”, to include natives } \\
\text { of the Tibet Autonomous } \\
\text { Region (Xizang zizhi qu 西 } \\
\text { 藏自治區) as well as those } \\
\text { of Kham and Amdo } \\
\text { (Qinghai) }\end{array}$ \\
\hline
\end{tabular}




\section{Bibliography}

Unpublished sources in archives and libraries.

-Sources with QZH (quanzonghao 全宗号) and AJH (anjuanhao 案卷号) are in the Sichuan Provincial Archives (Sichuan sheng dang'an guan 四川省 档案馆). In all other cases the holding institution is noted.

Chuanbian caizheng ting 川邊財政廳. Reports from Jinke weiyuan 金科委 員 to Jinwu zongju juzhang 金務總局局長, 1913, (Quanzong hao 全 宗号, hereafter QZH: 197, Anjuan hao 案卷号, hereafter AJH: 35).

- Reports from Jinke weiyuan 金科委員 to Jinwu zongju juzhang 金 務總局局長, 1919, (QZH: 197, AJH: 11).

. "Ge xian liangshui diaocha biao 各顯糧稅調查表," 1932, (QZH:

197, AJH: 42).

Chuanbian zhenshoushi shu 川邊鎮守使署. "Qi shui choubanchu cheng 契 稅籌辦處呈", 1914, (QZH: 195, AJH: 4).

Chuan Kang bian fang jun 川康邊防軍, Hu Renji 胡人紀, "Chengwei zunling huitong dianyan guanyun wula zaoce jicheng yangqi 呈為尊 令會同點驗官運烏拉造冊齊呈仰祈," (QZH:24, AJH:4).

Ningshu diaocha baogao huibian 寧屬調查報告彙編, 1939, (Beijing daxue library).

Xikang sheng canyihui 西康省參議會. "Linshi canyihui, di yi ci hui huibian 臨時參議會第一次會匯編," 1940, (QZH: 204, AJH: 14).

——. "Linshi canyihui, di san ci hui huibian 臨時參議會第三次會匯編," 1942, (QZH: 204, AJH: 16).

——. "Linshi canyihui, di er jie, di yi ci hui huibian 臨時參議會第二屆 , 第一次會匯編," 1943, (Shanghai Municipal Library).

Xikang sheng caizhengting 西康省財政廳. Tang Denghan 唐登漢, "Xikang sheng Kangding xian zhengfu chengbao dian mai qishui zhengshou 西康省康定縣政府呈報典買契稅徵收," 1940, (QZH:207, AJH:144). 
Xikang sheng nongye gaijin suo 西康省農業改進所. "Xikang sheng Ningshu senlin shiwusuo ying lin huading banfa 西康省寧屬森林事 務所營林劃定辦法," 1940, (QZH: 249, AJH: 79).

. "Zhengyong Simaqiao nongchang jingguo 征用馸馬橋農場經過," 1940, (QZH: 249; AJH: 81).

— "Kangding chengxiang wujia diaocha 康定城廂物價調查," 1940, (QZH: 249, AJH: 33).

- Simaqiao nongchang suozhang 司馬橋農場所長, [correspondence with head office], 1943, (QZH: 249, AJH: 89).

—. "Xikang sheng nongye gaijin suo xiang Simaqiao dizhu Wasi diao zujie Simaqiao tudi wei nongshi shiyanchang dang ping Kangding xian zhengfu ding heyue 西康省農業改進所向駆馬橋地主瓦司碉 租借馱馬橋土地為農事試驗場當憑康定縣政府訂定合約," 1943, (QZH: 249; AJH: 81).

—. Ningshu ban'gong shi shizhang Xu Xiaohui 甯屬辦公室室長徐孝 恢, correspondence with head office, 1944, (QZH: 249; AJH: 79).

—_. Ningshu banshi chu 寧屬辦事處, "Tuihuan Madaozi mianchang bufen zudi banfa 退還馬道子棉場部分租地辦法”, 1944, (QZH: 249, AJH: 79).

— N Ningqu nonglin chang changzhang Xie Kaiming 寧區農林場長長 謝開明, correspondence with Director of Agriculture Institute, 1945, (QZH: 249, AJH: 79).

. Hanyuan nong chang changzhang Yan Zhilong 漢源農場場長嚴治 隆, correspondence with Director of Agriculture Institute, 1947, (QZH: 249, AJH: 101).

— . "Xikang sheng tudi hukou diaochabiao 西康省土地戶口調查表," 1947, (QZH: 249, AJH: 152).

—. Ya'an nongchang changzhang 雅安農場場長, [correspondence with head office], 1947, (QZH: 249; AJH: 79).

— . "Kangding nongchang yewu gaikuang 西康省農業改進所康定農 場業務概況," 1949, (QZH: 249, AJH: 152).

."Kangding Yalatuo huangdi tunken jihua 康定亞拉沱荒地屯墾計 劃," 1949, (QZH: 249, AJH: 152). 
Xikang sheng tudi chenbao banshichu 西康省土地陳報辦事處, "Hanyuan xian di mu shuilü fu’e tongji biao 漢源縣地畧稅率賦額統計表," 1940, (QZH: 248, AJH: 2).

\section{Published Sources, and Masters and PhD theses}

Adshead, S. A. M. "The Opium Trade in Sichuan, 1881 to 1911." Journal of Southeast Asian History 7, no. 2 (1966): 93-99.

- Province and Politics in Late Imperial China: Viceregal Government in Szechwan, 1898-1911. London: Curzon Press, 1984.

Alai. Red Poppies. Translated by Howard Goldblatt and Sylvia Li-chun Lin. Boston: Houghton Mifflin, 2002.

The Analects of Confucius. Translated by Simon Leys. New York: W. W. Norton, 1997.

Anonymous (佚名). "Zhili Kangqu yijian shu 治理康区意见书." In Kangqu Zangzu shehui zhenxi ziliao jiyao 康区藏族社会珍稀资料辑要, edited by Zhao Xinyu 赵心愚, Qin heping 秦和平 and Wang Chuan 王川, 317-440. Chengdu: Bashu shu she, 2006.

Ba ren 巴人. "Xikang de xin Ba'an 西康的新巴安." Kangdao yuekan 康導 月刊 4, no. 4-5 合刊 (1943): 73-80.

Barnett, A. Doak. China's Far West: Four Decades of Change. Boulder: Westview Press, 1993.

. China on the Eve of Communist Takeover. New York: Frederick A. Praeger, 1963.

Baumler, Alan. The Chinese and Opium under the Republic Albany: State University of New York Press, 2007.

Bian, Morris L. The Making of the State Enterprise System in Modern China: The Dynamics of Institutional Change. Cambridge, Mass.: Harvard University Press, 2005.

Billingsley, Phil. Bandits in Republican China. Stanford: Stanford University Press, 1988.

Bobao yishu wang 博宝艺术网. "'Fei tian di yi tu" Changzheng wanli tu 18 ri zai Chengdu paimai “飞天第一图” 《长征万里图》18 日在成 都拍卖 " http://news.artxun.com/bimo-483-2414565.shtml. 
Buck, J. Lossing. An Agricultural Survey of Sichuan Province, China. Chungking: The Farmers Bank of China, 1943.

Cai Yuan 蔡远. "Xikang wang Liu Wenhui 西康王刘文辉." Wen shi jing hua 文史精华, no. 7 (1997): 46-50.

Candler, Edmund. The Unveiling of Lhasa. London: Thomas Nelson and Sons, 1905.

Ch'en, Jerome. The Highlanders of Central China: A History 1895-1937 Armonk, N. Y.: M. E. Sharpe, 1992.

Chang Longqing 常隆慶. Lei Ma E Ping diaocha ji 雷馬峨屏調查記. Chongqing: Zhongguo xi bu ke xue yuan, 1935.

Chen Dongfu 陳東府. "Zhao Ji he jingying Xikang zhi jingguo 趙季和經營 西康之經過." Kangdao yuekan 康導月刊 1, no. 1 (1938): 9-25.

Chen Yishi 陈一石. "Chuanbian Zangqu jiaotong wula chaiyao kaosuo 川边 藏区交通乌拉差徭考索." Xizang yanjiu 西藏研究, no. 1 (1984): 45-60.

. "Cong Qing mo Chuan-Dian bianwu dang'an kan Zhao Erfeng de zhi Kang zhengji 从清末川滇边务档案看赵尔丰的治康政绩." Jindai shi yanjiu 近代史研究, no. 2 (1985): 250-66.

Chen Zhongsheng 陳重生. Xi xing yan yi ji 西行灎異記. Shanghai: Shanghai shibao, 1930.

Chen Zhongwei 陳重為. Xikang wenti 西康問题. Shanghai: Zhonghua shu ju, 1930.

Cheng Yuandeng 程源澄. "Ningshu minying shiye xianzhuang 甯屬民營事 業現狀." In Xikang sheng jianshe xie jin hui hui wu nianbao: di san ci 西康省建設協進會會務年報: 第三次. Xichang: Xichang Ning yuan yinshua gongsi, 1948.

Cheng Yuqi 程裕淇. Xikang jianying 西康剪影: Duli chubanshe, 1945.

Chengdu Tanbengzi 成都弹朋子, "Chongfan Daliangshan 重返大凉山", Chengdu Tanbengzi Tianya blog 天涯博 客, http://blog.tianya.cn/blogger/view_blog.asp?idWriter $=0 \&$ Key $=0$ $\underline{\text { B } \log \text { Name }=\text { cdtanbengzi } \& \text { CategoryID }=283408 \& \text { page }=3 \& \mathrm{~b}=1 \& \mathrm{r}=3}$ \&nextid=88888888 [accessed 18 May 2011].

Chongqing Zhongguo yinhang diaocha zuzhi 重慶中國銀行調查組織. "Diaocha ziliao 調查資料." Chuanbian jikan 川邊季刊 2, no. 2 (1936): 126-278. 
. "Diaocha ziliao 調查資料." Chuanbian jikan 川邊季刊 1, no. 3 (1935): 157-230.

. "Diaocha ziliao 調查資料." Chuanbian jikan 川邊季刊 1, no. 4 (1935): 224-334.

—. "Diaocha ziliao 調查資料." Chuanbian jikan 川邊季刊 1, no. 2 (1935): 109-272.

—. "Diaocha ziliao 調查資料." Chuanbian jikan 川邊季刊 2, no. 1 (1936): 132-286.

—. "Diaocha ziliao 調查資料." Chuanbian jikan 川邊季刊 1, no. 1 (1935): 123-244.

—. "Ebian diaocha 峨邊調查." Chuanbian jikan 川邊季刊 1, no. 3 (1935): 15-107.

—. "Leibo diaocha 雷波調查,." Chuanbian jikan 川邊季刊 1, no. 4 (1935): 66-169.

——. "Mabian diaocha 馬邊調查." Chuanbian jikan 川邊季刊 1, no. 2 (1935): 18-108.

—. "Mabian Yi ren diaocha 馬邊夷人調查." Chuanbian jikan 川邊季 刊 1, no. 3 (1935): 108-45.

Clark, Paul. The Chinese Cultural Revolution: A History. Cambridge: Cambridge University Press, 2008.

Cliff, Thomas Matthew James. "Neo Oasis: The Xinjiang Bingtuan in the Twenty-first Century." Asian Studies Review 33, no. 1 (2009): 83106.

Coales, Oliver. "Narrative of a Journey from Tachienlu to Ch'amdo and back via Batang." In The History of Tibet: volume III, the Modern Period, edited by Alex McKay, 202-238. London: RoutledgeCurzon, 2003.

Coleman, William M. "The Uprising at Batang: Kham and its Significance in Chinese and Tibetan History " In Khams Pa Histories: Visions of People, Place and Authority edited by Lawrence Epstein, 31-56. Leiden: Brill, 2002.

Covell, Ralph. Mission Impossible: The Unreached Nosu on China's Frontier. Pasadena, California: Hope Publishing House, 1990.

D'Ollone, Vicomte. In Forbidden China: the D'Ollone Mission, 1906-1909: China-Tibet-Mongolia. Translated by Bernard Miall. Boston: Small, Maynard and Company, 1912. 
Dai, Yingcong. "The Qing State, Merchants, and the Military Labor Force in the Jinchuan Campaigns." Late Imperial China 22, no. 2 (2001): 3590 .

Dao Xue 稻雪. "Xikang Taining shiyanqu diaocha 西康泰宁试验区调查." Xin Kang bao 新康报 1, no. 2 (1938).

Davies, H. R. Yün-nan, the link between India and the Yangtze. Taipei: Ch'eng Wen Publishing Company, 1970 [1909].

Deng Qiancheng 邓前程. "Lun Qing mo Chuanbian kenzhi 论清末川边垦 殖." Sixiang zhanxian 思想战线, no. 3 (2007): 55-69.

Des Forges, Roger V. Hsi-liang and the Chinese National Revolution. New Haven: Yale University Press, 1973.

Dreyer, June Teufel. China's Forty Millions: Minority Nationalities and National Integration in the People's Republic of China. Cambridge, Massachusetts: Harvard University Press, 1976.

Du Mingyi 杜明燡. "E Ma Lei Ping bianwu cha biao ce 峨馬雷屏邊務查表 冊." In Zhongguo shaoshu minzu guji jicheng. Han yihou Xinan ge minzu 中國少數民族古籍集成。漢以後西南各民族, Vol. 94, 40438. Chengdu: Sichuan minzu chubanshe, 2002.

Du Yuting 杜玉亭. "Yunnan Xiao Liangshan Yizu de nuli zhidu 云南小凉 山彝族的奴隶制度." In Yunnan Xiao Liangshan Yizu shehui lishi diaocha 云南小凉山彝族社会历史调查, edited by Minzu wenti wuzhong conghsu Yunnan sheng bianji weiyuanhui 《民族问题五种 丛书》云南省编辑委员会. Beijing: Minzu chubanshe, 2009.

Duara, Prasenjit. Culture, Power, and the State: Rural North China, 19001942. Stanford: Stanford University Press, 1988.

Eisenstadt, S. N. "Multiple Modernities." Daedalus 129, no. 1 (2000): 1-29.

Fan Rusen 㚞如森. "Qingmo minguo shiqi Xinjiang de bentuhua kaifa 清末 民国时期新疆的本土化开发." In Bianjie, biandi yu bianmin: Ming Qing shiqi beifang biansai diqu buzu fenbu yu dili shengtai jichu yanjiu 边界、边地与边民: 明清时期北方边塞地区部族分布与地 理生态基础研究, edited by An Jiesheng 安介生 and Yue Zhonglin 岳仲麟, 239-249. Jinan: Qilu shushe, 2009.

Fergusson, W.N. Adventure, Sport and Travel on the Tibetan Steppes. London: Constable and Company, Ltd., 1911.

Fleming, Peter. Bayonets to Lhasa: the First Full Account of the British Invasion of Tibet in 1904. London: R. Hart-Davis, 1961. 
Foucault, Michel, and Colin Gordon. Power/knowledge: selected interviews and other writings, 1972-1977; edited by Colin Gordon; translated by Colin Gordon et al. Brighton, Sussex: Harvester Press, 1980.

Freedman, Maurice. The Study of Chinese Society: Essays by Maurice Freedman, selected and introduced by G. William Skinner. Stanford: Stanford University Press, 1979.

Fu Songmu 傅嵩炑. Xikang jiansheng ji 西康建省記. 3 vols. Beijing: Zhongguo Zang xue chubanshe, 1988 [1912].

Fu Zhenyuan 傅真元. "Liang yan hong zhao di zhi neirong ji qi jiejue zhi tujing 两盐红照地之内容及其解决之途径." Kangdao yuekan 康導 月刊 4, no. 8-9 合刊 (1941): 42-46.

Giersch, C. Patterson. Asian Borderlands: The Transformation of Qing China's Yunnan Frontier. Cambridge, Mass.: Harvard University Press, 2006.

_. "'A Motley Throng:" Social Change on Southwest China's Early Modern Frontier, 1700-1800." The Journal of Asian Studies 60, no. 1 (2001): 67-94.

Gill, W. J. "Travels in Western China and on the Eastern Borders of Tibet." Journal of the Royal Geographical Society of London 28 (1878): 57172.

Goldstein, Melvyn C. A History of Modern Tibet, 1913-1951: the Demise of the Lamaist State. Berkeley: University of California Press, 1989.

_. "Taxation and the Structure of a Tibetan Village." Central Asiatic Journal 15, no. 1 (1971): 1-27.

Goldstein, Melvyn C., T.N. Shelling, and J.T. Surkhang, eds. The New Tibetan-English Dictionary of Modern Tibetan. Berkeley: University of California Press, 2001.

Goré, F., and Li Zhesheng 李哲生 (trns.). "Kang Zang minzu za xie 康藏民 族雜寫 [Notes sur les Marches Tibétaines du Sseu-tch'ouan et du Yun-nan]." Kang Zang yanjiu yuekan 康藏研究月刊, no. 28-29 合刊 (1949 [1923]): 43-53.

Goullart, Peter. Princes of the Black Bone: Life in the Tibetan Borderland. London: John Murray Publishers, 1959.

Gu Xueqiu 顾学雸. "Xikang sheng yaocai diaocha baogaoshu 西康省药材 调查报告书." In Minguo shiqi Xizang ji Kangqu jingji kaifa jianshe dang'an xuanbian 民国时期西藏及康区经济开发建设档案选编, edited by Liu Limei 刘丽椐 and Cao Bihong 曹必宏, 407-415. Beijing: Zhongguo Zangxue chubanshe, 2005 [1939]. 
Guha, Ramachandra. The Unquiet Woods: Ecological Change and Peasant Resistance in the Himalaya. Oxford: Oxford University Press, 2000.

Gunde, Richard. "Land Tax and Social Change in Sichuan, 1925-1935." Modern China 2, no. 23 (1976): 23-48.

Guo, Xiaolin. State and Ethnicity in China's Southwest. Leiden: Brill, 2008.

Guomin canzheng hui. Chuan kang jianshe shicha tuan 國民參政會. 川康建 設視察團, ed. Guomin canzhenghui Chuan-Kang jianshe shichatuan baogao shu 國民參政會川康建設視察團報告書. Taibei: Wenhai chubanshe youxian gongsi, 1971 [1939].

Guomin geming jun di ershisi jun 国民革命军第二十四军. "Chuan Kang bianwu xuanchuan jiyao 川康边务宣传辑要." In Kangqu Zangzu shehui zhenxi ziliao jiyao (shang) 康区藏族社会珍稀资料辑要（上 ), edited by Zhao Xinyu 赵心愚, Qin Heping 秦和平 and Wang Chuan 王川. Chengdu: Bashu shushe, 2006.

Harrell, Stevan, "Ethnicity, Local Interests, and the State: Yi Communities in Southwest China," Comparative Studies in Society and History 32, no. 3 (1990): 515-548.

_ . "Introduction." In Perspectives on the Yi of Southwest China, edited by Stevan Harrell, 1-20. Berkeley: University of California Press, 2001.

Harrell, Stevan, and Yongxiang Li. "The History of the Yi, Part II." Modern China 29, no. 3 (2003): 562-396.

He Yimin 何一民. "20 shji chu nian Chuanbian Zangqu zhengzhi jingji wenhua gaige shulun 20 世纪初年川边藏区政治经济文化改革述论 ."Xinan minzu xueyuan xuebao 西南民族学院学报（哲学社会科学 版） 22, no. 6 (2001): 39-49.

Herman, John E. Amid the Clouds and Mist: China's Colonization of Guizhou, 1200-1700. Cambridge (Mass.): Harvard University Press, 2007.

Hill, Ann Maxwell. "Captives, Kin, and Slaves in Xiao Liangshan." The Journal of Asian Studies 60, no. 4 (2001): 1033-49.

_. "Provocative Behavior: Agency and Feuds in Southwest China." American Anthropologist 106, no. 4 (2004): 675-86.

Ho, David Dahpon. "The Men Who Would Not Be Amban and the One Who Would: Four Frontline Officials and Qing Tibet Policy, 1905-1911." Modern China 34, no. 2 (2008): 210-46. 
Hosie, Alexander. On the Trail of the Opium Poppy: A Narrative of Travel in the Chief Opium-Producing Provinces of China. 2 vols. Vol. 2. London: George Philip \& Son, 1914.

- Three Years in Western China: A Narrative of Three Journeys in Ssu-chuan, Kuei-chow, and Yün-nan. London: George Philip \& Son, 1897.

Hsiang, C.-Y. "Mountain Economy in Sichuan." Pacific Affairs 14, no. 4 (1941): 448-62.

Hu Chaojun 胡朝均, and Li Jing 李静. "Wo zai Yi qu jingshang de jingyan 我在彝区经商的经验." In Liangshan Yizu wenshi ziliao zhuanji 凉 山彝族文史资料专辑, edited by Yang Ling 杨凌 and Chen Hua 陈 华, 73-74. Chengdu: Sichuan minzu chubanshe, 2000.

Hu Xiaomei 胡晓梅. "Liu Wenhui Kangqu wula zhidu gaige shulun 刘文辉 康区乌拉制度改革述论." Sichuan jiaoyu xueyuan xuebao 四川教育 学院学报 18, no. 9 (2002): 36-39.

Huang Fensheng 黃奮生, ed. Meng Zang xin zhi 蒙藏新志. Shanghai: Zhonghua shu ju, 1938.

Huang, Philip C. C. Code, Custom and Legal Practice in China: The Qing and the Republic Compared. Stanford: Stanford University Press, 2001.

- The Peasant Economy and Social Change in North China. Stanford: Stanford University Press, 1985.

Huang Shangcheng 黃上成. "Xikang wula chaiyao zhidu zhi shi de xushu 西康烏拉差徭制度之史的敘述." Kangdao yuekan 康導月刊 2, no. 5 (1940): 23-95.

Huang Shuyu 黃樹玉. "Jianshe Xikang ying cezhong Ningshu 建設康西康 應側重甯屬." Kangdao yuekan 康導月刊 1, no. 5 (1939): 165-68.

Huang Tianhua 黄天华. "Liu Wenhui yu Ganzi shijian 刘文辉与甘孜事件." Xinan minzu daxue xue bao (renwen sheke ban) 西南民族大学学报 (人文社科版), no. 3 (2009): 33-40.

———. "Lun minguo shiqi Xikang jian sheng 论民国时期西康建省." Sichuan shifan daxue xuebao 四川师范大学学报（社会科学版） 28, no. 4 (2001): 95-100.

Huber, Toni. "Territorial Control by 'Sealing' (rgya sdom-pa): A ReligioPolitical Practice in Tibet." Zentralasiatische Studien 33 (2004): 12752. 
Hui Fuping 惠富平. "Qing mo min chu xing nong sixiang shuping 清末民初 兴农思想述评." Nanjing nongye daxue xuebao (shehui kexue ban) 南京农业大学学报 (社会科学版), no. 1 (2003): 63-67.

Isett, Christopher Mills. State, Peasant and Merchant in Qing Manchuria, 1644-1862. Stanford: Stanford University Press, 2006.

Jack, R. Logan. The Back Blocks of China: A Narrative of Experiences among the Chinese, Sifans, Lolos, Tibetans, Shans and Kachins between Shanghai and the Irrawadi. London: Edward Arnold, 1904.

Jäschke, H.A. A Tibetan-English Dictionary, with special reference to the prevailing dialects. London: Routledge \& Kegan Paul, 1881.

Jiang Junzhang 蔣君章. "Wula wenti zhi jiejue tujing 烏拉問題之解決途徑 ." Bianzheng gonglun 邊政公論 1, no. 7-8 (combined) (1941): 16-33.

Jiang Wuji 蒋五瀷. "Yutong suoying 鱼通缩影." Kangdao yuekan 康導月 刊 1, no. 1 (1938): 113-26.

Jin Gaiping 金蓋坪. "Kangding zuzhi kenmu gongsi 康定組織墾牧公司." Sichuan nongye 四川農業 1, no. 11-12(合刊) (1934): 112-13.

Johnson, J. C. F. Getting Gold: A Practical Treatise for Prospectors, Miners, and Students London: Charles Griffin, 1897.

Junshi weiyuanhui weiyuanzhang xingying bianzheng sheji weiyuanhui 軍 事委員會委員長行營邊政設計委員會. "Chuan-Kang bianzheng ziliao jiyao 川康邊政資料輯要." In Minguo Zang shi shi liao huibian 民国藏事史料汇编, edited by Zhang Yuxin 张羽新 and Zhang Shuangzhi 张雙志. Beijing: Xuefan chubanshe, 2005 [1940].

Juvaini, Ata-Malik, John Andrew Boyle, and David Morgan. Genghis Khan: the History of the World Conqueror. Translated by John Andrew Boyle. Manchester: Manchester University Press, 1997.

Kang Run 康潤. "Wo duiyu dangqian zhi yi de yijian 我對于當前治夷的意 見." Daliangshan 大涼山 1, no. 1 (1946): 1-5.

Kapp, Robert A. Szechwan and the Chinese Republic: Provincial Militarism and Central Power, 1911-1938 New Haven and London: Yale University Press, 1973.

Ke Xiangfeng 柯象峰. "Xikang ji xing (xu wan) 西康紀行 (續完)." Bianzheng gonglun 邊政公論 1, no. 9-10 合刊 (1942): 84-104.

Kolmas, Josef. Chinese Studies on Tibetan Culture: a Facsimile Reproduction of the K'ang-Tsang Yen-chiu Yüeh-k'an (Hsik'ang-Tibet Research Monthly). New Delhi: International Academy of Indian Culture, 1983. 
Kumar, Sunil. "The Ignored Elites: Turks, Mongols and a Persian Secretarial Class in the Early Delhi Sultanate." Modern Asian Studies 43, no. 1 (2007): 45-77.

Lai Zuozhong 来作中. "Jiefang qian Ganzi Zang qu de huangjin shengchan 解放前甘孜藏区的黄金生产." In Ganzi Zhou wenshi ziliao, no. 14 甘孜州文史资料，第十四辑, edited by Zhongguo renmin zhengzhi xieshang huiyi Ganzi Zangzu zizhizhou weiyuanhui 中国人民政治 协商会议甘孜藏族自治州委员会, 110-118. Kangding: Kangding xian yinshua chang, 1996.

Lattimore, Owen. "Chinese Colonization in Manchuria." Geographical Review 22, no. 2 (1932): 177-95.

Lei Yi 雷颐. "Qing mo "min you" yu "min ying" de ji dou 清末 “民有” 与 “民营” 的激斗." Nanfang Zhoumo 南方周末, 14-06 2007.

Leibold, James. Reconfiguring Chinese Nationalism: How the Qing Frontier and its Indigenes Became Chinese. New York: Palgrave Macmillan, 2007.

Li, Bozhong. "Farm Productivity in Jiangnan, 1620-1850." In Living Standards in the Past: New Perspectives on Well-Being in Asia and Europe, edited by Robert C. Allen, Tommy Bengtsson and Martin Dribe, 55-76. Oxford: Oxford University Press, 2005.

Li Deying 李德英. "Minguo shiqi Chengdu pingyuan de yazu yu yakou 民 国时期成都平原的押租与押扣." Jindai shi yanjiu 近代史研究, no. 1 (2007): 95-115.

Li Hongbin 李鸿涁, and Bai Jie 白杰. "Ping Qianlong chao Jinchuan zhi yi 评乾隆朝金川之役." Qing shi yanjiu 清史研究, no. 2 (1998): 66-76.

Li Jingxuan 李靜軒. "Ganzi shibian zhi zeren wenti 甘孜事變之責任問題." Kangdao yuekan 康導月刊 2, no. 8 (1940): 11-14.

Li Maoyu 李茂郁. "Lun Zhao Erfeng 论赵尔丰." Shehui kexue yanjiu 社会 科学研究, no. 4 (2002): 124-29.

———. "Shi lun Qing mo Chuan bian gaitu guiliu 试论清末川边改土归流 ." Xizang yanjiu 西藏研究, no. 2 (1984): 5-22.

Li Shaoming 李绍明. "Sichuan minzu diqu minzhu gaige de lishi huigu 四 川民族地区民主改革的历史回顾." Xinan Minzu Daxue xuebao (renwen sheke ban) 西南民族大学学报（人文社科版）, Jan. (2008), 34-44. 
Li Xizhu 李细珠. "Shilun Qing mo xin zheng shiqi zheng qu gaige de ji ge wenti 试论清末新政时期政区改革的几个问题." Jindai shi yanjiu 近代史研究, no. 2 (2003): 100-23.

Li Zhiming 李志茗. "Yong ying zhidu: Qing dai jun zhi de zhong jian xingtai 勇营制度: 清代军制的中间形态." Shi lin 史林, no. 4 (2006): 29-34.

Li Zhuxi 李竹溪, Zeng Dejiu 曾德久, and Huang Weihu 黄为虎, eds. Jindai Sichuan wujia shiliao 近代四川物价史料. Chengdu: Sichuan kexue jishu chubanshe, 1986.

Liao T'ai-chu'u. "The Ko Lao Hui in Szechuan " Pacific Affairs 20, no. 2 (1947): 161-73.

Lin Chengxi 林成西. "Yimin yu Qing dai Sichuan minzu diyu jingji 移民与 清代四川民族区域经济." Xinan minzu daxue xue bao (renwen sheke ban) 西南民族大学学报（人文社科版) 11, no. 183 (2006): 187-90.

Lin, Hsiao-ting. Tibet and Nationalist China's Frontier: Intrigues and Ethnopolitics, 1928-49. Vancouver: University of British Columbia Press 2006.

Lin Yueh-hua. The Lolo of Liangshan [Liangshan yi jia 凉山夷家]. Translated by Ju-Shu Pan. New Haven: HRAF Press, 1961.

Ling Guangdian 嶺光電. "Wo dui Leibo Yi ren de guangan 我對雷波夷人 的觀感." Kang Zang yanjiu yuekan 康藏研究月刊, no. 11 (1946): 28-32.

Little, Archibald John. Mount Omi and Beyond: A Record of Travel on the Thibetan Border: W. Heinemann, 1901.

Liu Cuirong 刘翠溶, and Fan Yijun 范毅军. "Shi cong huanjing shi jiaodu jiantao Qingdai Xinjiang de tuntian 试从环境史角度检讨清代新疆 的屯田." Zhongguo shehui lishi pinglun 中国社会历史评论 8 (2007): 183-227.

Liu Hengru 刘衡如, Yang Zihe 杨子和, Li Zhangfu 李章甫, and Zheng Shaocheng 郑少成. "Shicha Dao Lu De Bai Zhan Ya Jiang qi xian baogaoshu 视察道炉甘德白瞻雅江七县报告书." Xin Xikang 新西 康 1, no. 2-3 (1938).

Liu Jianbang 刘建邦. "Qing mo Min(guo) chu Xikang dongbu ge xian kenwu gaikuang 清末民（国）初西康东部各县叚务概况." In Ganzi Zhou wenshi ziliao, no. 14 甘孜州文史资料, 第十四辑, edited by Zhongguo renmin zhengzhi xieshang huiyi Ganzi Zangzu 
zizhizhou weiyuanhui 中国人民政治协商会议甘孜藏族自治州委 员会. Kangding: Kangding xian yinshua chang, 1996.

Liu Jun 刘君. "Jian lun Xikang sheng 简论西康省." In Minguo dang'an yu minguo shi xueshu taolunhui lunwen ji 民国档案与民国史学术讨论 会论文集, edited by Zhang Xianwen 张宪文, Chen Xingtang 陈兴唐 and Zheng Huixin 郑会欣, 321-31. Beijing: Dang'an chubanshe 1988.

. "Jindai Sichuan Zangqu yapian maoyi jiqi shehui weihai 近代四川 藏区鸦片贸易及其社会危害." Zhongguo Zangxue 中国藏学, no. 3 (2002): 50-58.

Liu Shangxin 劉尚新. "Ningshu jishi 寧屬紀實." Chuanbian jikan 川邊季 刊 1, no. 4 (1935).

Liu Shiquan 刘仕权. "San-sishi niandai Kangding chengqu "jinrong huobi" "shangpin jiage" de jianshu 三、四十年代康定城区 “金融货币” “商品价格” 的简述." In Ganzi Zhou wenshi ziliao, no. 11 甘孜州 文史资料，第十一辑, edited by Zhongguo renmin zhengzhi xieshang huiyi Ganzi Zangzu Zizhizhou weiyuanhui 中国人民政治 协商会议甘孜藏族自治州委员会. Kangding: Ganzi baoshe yinshua chang, 1990.

Liu Wenhui 刘文辉. Zoudao renmin zhenying de lishi daolu 走到人民阵营 的历史道路. Beijing: Shenghuo, dushu, xinzhi sanlian shudian, 1979.

Liu Wenhui 劉文輝. "Ganzi shibian jiejue jingguo 甘孜事變解決經過." Kangdao yuekan 康導月刊 2, no. 8 (1940): 2-9.

. "Jianshe xin Xikang shi jiang 建設新西康十講,." In Kang qu Zang zu shehui zhenxi ziliao jiyao (xia) 康区藏族社会珍稀资料辑要 (下), edited by Zhao Xinyu 赵心愚, Qin Heping 秦和平 and Wang Chuan 王川. Chengdu: Shu ba shushe, 2006.

—. "Ningshu Yi wu wenti zhi jiantao 甯屬夷務問題之檢討." Kangdao yuekan 康導月刊 2, no. 3 (1939): 1-6.

——. "Xikang chaiyao zhi guoqu yu jianglai 西康差徭之過去與將來." Kangdao yuekan 康導月刊 2, no. 5 (1940): 3-5.

"Xikang xiankuang ji Zhao Erfeng zhi Zang zhi shi de 西康現況及 趙爾豐治藏之失得." Xibei wenti jikan 西北問題季刊 2, no. 1-2 (合 刊） (1936): 15-29. 
Liu Xiangxiu 刘祥秀. "1903-1949 nian guojia bianjiang kaifa zhengce xia de Kang qu tudi liyong ji qi huanjing bianhua 1903-1949 年国家边 疆开发政策下的康区土地利用及其环境变化." Shaanxi Normal University, 2007.

Liu Xiangxiu 刘祥秀, and Guo Pingruo 郭平若. "Qing mo tun ken zhengce zai Chuanbian Zang qu de shishi ji dui huanjing de yingxiang 清末屯 剭政策在川边藏区的实施及其对环境的影响." Xizang yanjiu 西藏 研究, no. 2 (2007): 16-22.

Liu Yiyan 劉貽燕. "Wu nian lai Xikang nongye jianshe zhi huigu 五年來西 康建設之回顧." Xikang jingji jikan 西康經濟季刊 1, no. 8 (1944): $1-15$.

Liu Yuanxuan 劉元瑄. "San hua zhengce yu san min zhuyi 三化政策與三 民主義." Bianzheng yuekan 邊政月刊 1, no. 4-6(合刊) (1944): 3444.

Liu Yuetian 劉躍天. "Zhengli Yanyuan Yi wu chu yi 整理鹽源夷務芻議." Kangdao yuekan 康導月刊 2, no. 4 (1939): 22-23.

Liu Zhenggang 刘正刚, and Tang Weihua 唐伟华. "Qing dai yimin yu Han Yi jiaoliu tantao 清代移民与汉彝交流探讨." Guizhou minzu yanjiu 贵州民族研究 22, no. 90 (2002): 145-50.

Luo Guanzhong. Three Kingdoms: a Historical Novel. Translated by Moss Roberts. Berkeley: University of California Press, 1991.

Luo Guanzhong 罗贯中. San guo yan yi 三国演义. Harbin: Heilongjiang chubanshe, 2003.

Ma Jinglin 马菁林. "'Gai tu gui liu" de hongguan lishi fenxi “改土归流” 的宏观历史分析." Xizang yanjiu 西藏研究, no. 3 (2001): 82-87.

—. Qing mo Chuanbian Zang qu gaitu-guiliu kao 清末川边藏区改土 归流考 Chengdu: Sichuan chuban jituan, 2002.

Ma Naihui 马舅辉, Wang Zhaowu 王昭武, and Zhuang Wenjun 庄文骏, eds. Chenfeng de lishi shunjian: sheying dashi Zhuang Xueben 20 shiji 30 niandai de xibu renwen tanfang 尘封的历史瞬间: 摄影大 师庄学本 20 世纪 30 年代的西部人文探访. Chengdu: Sichuan minzu chubanshe, 2005.

Ma Zhongliang 馬忠良, and Sun Qiangzeng 孫鏘增. "Yuesui ting zhi 越崔 廳志 [1906]." In Zhongguo Xizang ji Gan Qing Chuan Dian Zangqu fangzhi huibian 中國西藏及甘青川滇藏區方志彙編, Vol 39, edited by Zhang Yuxin 张羽新, 1-250. Beijing: Xueyuan chubanshe, 2003. 
MacDonald, Kenneth Iain. "Push and Shove: Spatial History and the Construction of a Portering Economy in Northern Pakistan." Comparative Studies in Society and History 40, no. 2 (1998): 287317.

Meng Yongxi 蒙永锡. "Shiqu xianzhuang sumiao 石渠现状素描." Kangdao yuekan 康導月刊 2, no. 8 (1940): 55-71.

Menzies, Nicholas K. . "Sources of Demand and Cycles of Logging in PreModern China." In Changing Pacific Forests: Historical Perspectives on the Forest Economy of the Pacific Basin edited by John Dargavel and Richard Tucker, 64-76. Durham, North Carolina: Forest History Society, 1992.

Meserve, Ruth. "The Inhospitable Land of the Barbarian." Journal of Asian History 16, no. 1 (1982): 51-89.

Millward, James A. Beyond the Pass: Economy, Ethnicity, and Empire in Qing Central Asia. Stanford: Stanford University Press, 1998.

_. Eurasian Crossroads: A History of Xinjiang. New York: Columbia University Press, 2007.

Mitchell, Timothy. "The Limits of the State: Beyond Statist Approaches and Their Critics." The American Political Science Review 85, no. 1 (1991): 77-96.

Mo Dehui 莫德惠. "Ningshu zhi Yi zhi wo jian 寧屬治夷之我見." Kangdao yuekan 康導月刊 5, no. 11-12 (合刊) (1943): 80-82.

Mosca, Matthew W. "Empire and the Circulation of Frontier Intelligence: Qing Conceptions of the Ottomans." Harvard Journal of Asiatic Studies 70, no. 1 (2010): 147-207.

Myers, Ramon H. The Chinese Peasant Economy: Agricultural Development in Hopei and Shantung, 1890-1949. Harvard University Press: Cambridge, Mass., 1970.

Ni Liangduan 倪良端. "Liu Wenhui de rensheng licheng 刘文辉的人生历 程." Sichuan tong yi zhan xian 四川统一战线, June, (2006): 33-35.

Pathak, Shekhar. "The Begar Abolition Movements in British Kumaun." Indian Economic Social History Review, no. 28 (1991): 261-79.

Pei Jingfu 裴景福. He hai Kunlun lu 河海昆崙录. Lanzhou: Gansu renmin chubanshe, 2002 [1906].

Peng Dixian 彭迪先, Shu Guofan 舒国藩, Dai Shuyun 代淑筠, and Yan Zhimin 鄢智敏, eds. Liu Wenhui shihua 刘文辉史话. Chengdu: Sichuan daxue chubanshe, 1990. 
Peng Wenbin. "Frontier Process, Provincial Politics and Movements for Khampa Autonomy During the Republican Period." In Khams $\mathrm{Pa}$ Histories: Visions of People, Place and Authority, edited by Lawrence Epstein, 57-84. Leiden; Boston: Brill, 2002.

Peng Zhiyan 彭陟炎. "Shi lun Qianlong pingding Jinchuan zhi yingxiang 试 论乾隆评定金川之影响." Xizang yanjiu 西藏研究, no. 1 (2003): 92-97.

Perdue, Peter C. Exhausting the Earth: State and Peasant in Hunan, 15001850. Cambridge, Mass.: Council on East Asian Studies, Harvard University, 1987.

. "Empire and Nation in Comparative Perspective: Frontier Administration in Eighteenth-Century China." Journal of Early Modern History 5, no. 4 (2001): 282-304.

. China Marches West: The Qing Conquest of Central Eurasia. Cambridge, Mass.: Harvard University Press, 2005.

Perkins, Dwight H. Agricultural Development in China, 1368-1968. Edinburgh: Edinburgh University Press, 1969.

Pollard, Samuel. In Unknown China: a record of the observations, adventures and experiences of a pioneer missionary during a prolonged sojourn amongst the wild and unknown Nosu tribe of western China. London: Seeley, Service and Co., 1921.

Pomeranz, Kenneth. "Beyond the East-West Binary: Resituating Development Paths in the Eighteenth-Century World." The Journal of Asian Studies 61, no. 2 (2002): 539-90.

- The Making of a Hinterland: State, Society and Economy in Inland China, 1853-1937. Berkeley: University of California Press, 1993.

Qin Hancai 秦翰才. Zuo Wenxiang gong zai xibei 左文襄公在西北. Changsha: Yuelu shushe, 1984 [1946].

Qin, Liyan. "The Sublime and the Profane: A Comparative Analysis of Two Fictional Narratives about Sent-down Youth." In The Chinese Cultural Revolution as History, edited by Joseph W. Esherick, Paul G. Pickowicz and Andrew G. Walder, 240-266. Stanford: Stanford University Press 2006.

Qiu Shuling 邱述鈴. "Jiulong jingji jianshe zhi yantao 九龍經濟建設之研 討." Kangdao yuekan 康導月刊 2, no. 1 (1939): 40-46.

Reardon-Anderson, James. Reluctant Pioneers: China's Expansion Northward, 1644-1937. Stanford: Stanford University Press, 2005. 
Remick, Elizabeth J. Building Local States: China during the Republican and post-Mao eras. Cambridge, Mass.: Harvard University Asia Center, 2004.

—. "The Significance of Variation in Local States: The Case of Twentieth Century China." Comparative Politics 34, no. 4 (2002): 399-418.

Ren Hanguang 任汉光. "Kongyu Kaochaji 孔玉考察记 " Kangdao yuekan 康導月刊 1 , no. 1 (1938): 113-26.

Ren Naiqiang 任乃强. "Kangding xian shicha baogao 康定縣視察報告." Bianzheng , 邊政 no. 2 (1929). Reprinted in Kangqu Zangzu shehui lishi diaocha ziliao jiyao 康区藏族社会历史调查资料辑要, edited by Zhao Xinyu 赵心愚, and Qin Heping 秦和平, 255-272. Chengdu: Sichuan minzu chubanshe, 2004.

—. "Luding kaocha ji 瀘定考察記." In Minzu yanjiu wenji 民族研究文 集, edited by Ding Shihao 丁师浩, 58-117. Beijing: Minzu chubanshe, 1990.

. "Luding xian shicha bagao 瀘定縣視察報告." Bianzheng 邊政, no. 2 (1929). Reprinted in Kangqu Zangzu shehui lishi diaocha ziliao jiyao 康区藏族社会历史调查资料辑要, edited by Zhao Xinyu 赵心 愚, and Qin Heping 秦和平, 330-340. Chengdu: Sichuan minzu chubanshe, 2004.

‥ Xikang tujing 西康图经. Shanghai: Shanghai shudian, 1996 [1933]. "Xikang yuncang de fu li yu jianshe de tujing 西康藴藏的富力與 建設的途徑." Xibei wenti jikan 西北問題季刊 2, no. 1 (1936): 5260.

——. "Lun Ningyuan qu zhi jing jian buzhou 論寧遠區之經建步驟." Kang Zang yanjiu yuekan 康藏研究月刊 1, no. 3 (1946): 2-9.

Ren Xiaozhuang 任篠莊. "Chuanbian ken mu gongsi jingying shiye jihua 川 邊墾牧公司經營事業計劃." Chuanbian jikan 川邊季刊 2, no. 2 (1936): 154-77.

Ren Xinjian 任新建. "Jindai Sichuan Zang qu de huangjin kaifa 近代四川藏 区的黄金开发." In Sichuan Zangxue lunwen ji 四川藏学论文集, edited by Luo Runcang 罗润苍 and Ren Xinjian 任新建, 35-52. Beijing: Zhongguo Zangxue chubanshe, 1993.

Ren Zhuo 任灼. "Wula zhidu yu guan ying mu yun 烏拉制度與官營牧運." Kangdao yuekan 康導月刊 2, no. 5 (1940): 13-18.

Roosevelt, Theodore, and Kermit Roosevelt. Trailing the Giant Panda. New York Charles Scribner's Sons, 1929. 
Sautman, Barry. "Tibet and the (Mis-) Representation of Cultural Genocide." In Cultural Genocide and Asian State Peripheries, edited by Barry Sautman, 165-272. New York: Palgrave Macmillan, 2006.

Scott, James C. The Art of Not Being Governed: An Anarchist History of Upland Southeast Asia. New Haven: Yale University Press, 2009.

Shang Cheng 尚诚. "Kangbei de shengdi -- Taining 康北的圣地 -- 泰宁." Kangdao yuekan 康導月刊 5, no. 5 (1943): 52-59.

Shelton, Flora Beal. Shelton of Tibet. New York: George H. Doran Company, 1923.

Shen Tao 沈蹈. "Gong Zizhen yu Wei Yuan xibei kaifa sixiang zhi bijiao 龚 自珍与魏源西北开发思想之比较." Chongqing keji xueyuan xuebao (shehui kexue ban) 重庆科技学院学报 (社会科学版), no. 7 (2010): 145-47.

Shepherd, John Robert. Statecraft and Political Economy on the Taiwan Frontier, 1600-1800. Stanford: Stanford University Press, 1993.

Sheridan, James E. China in Disintegration: the Republican Era in Chinese History, 1912-1949. New York: Macmillan, 1975.

Shi Wen 石聞. "Xikang wei Zhongguo yin lai de san da wenti: yapian, yiwu yu Yingguo shili de ruqin 西康為中國引來的三大問題: 鴉片, 夷 務與英國勢力的入侵." Shi yu wen 時與文 3, no. 22 (1948): 11-12.

Sichuan minzu yanjiu suo 四川民族研究所, ed. Qing mo Chuan Dian bianwu dang'an shi liao 清末川滇边务档案史料. 3 vols. Beijing: Zhonghua shuju, 1989.

Sichuan shehui kexue yanjiuyuan 四川社会科学研究院, and Xizang zizhiqu shehui kexue yuan 西藏自治区社会科学院, eds. Chuanbian lishi ziliao huibian. Di er ce: Zhao Erfeng jingying Chuanbian de junshi huodong, di yi zhang: you guan Zhao Erfeng zhuanji 川边历 史资料汇编。第二册: 赵迩丰经营川边的军事活动, 第一章: 有关赵尔丰的传记, 1984 .

Sichuan sheng dang'an guan 四川省档案馆, and Sichuan minzu yanjiu suo 四川民族研究所, eds. Jindai Kang qu dang'an ziliao xuanbian 近代 康区档案资料选编. Chengdu: Sichuan daxue chubanshe, 1990.

Sichuan sheng Mianning xian difang zhi bianzuan weiyuanhui 四川省冕宁 县地方志编纂委员会, ed. Mianning xian zhi 冕宁县志. Chengdu: Sichuan minzu chubanshe, 1994.

Sichuan shengzhi jiaotong zhi bianji zu 四川省志交通志编辑组. "Chuanbian Zang qu yunshu "wula" shugai 川边藏区运输 “乌拉” 
述概." In Sichuan wenshi ziliao xuanji, di shisan ji 四川文史资料选 辑, 第十三辑, edited by Sichuan sheng shengzhi bianji weiyuanhui 四川省省志编辑委员会. Chengdu: Zhongguo renmin zhengzhi xieshang huiyi Sichuan sheng weiyuanhui, 1964.

Sigel, Louis T. "Ch'ing Tibetan Policy (1906-1910)." In Papers on Asia, vol. 20, 177-201. Cambridge, Mass.: East Asian Research Center, Harvard University, 1966.

Sima Qian 司馬遷. Shi ji 史記. Beijing: Zhonghua shuju, 1987.

Skinner, G. William "Aftermath of Communist Liberation in the Chengtu Plain." Pacific Affairs 24, no. 1 (1951): 61-76.

Smith, John Masson Jr. "Mongol and Nomadic Taxation." Harvard Journal of Asiatic Studies 30 (1970): 46-85.

Spengen, Wim van. Tibetan Border Worlds: a Geohistorical Analysis of Trade and Traders. London; New York: Kegan Paul International, 2000.

Sperling, Elliot. "The Chinese Venture in K'am, 1904-1911, and the Role of Chao Erh-feng." The Tibet Journal 1, no. 2 (1976): 10-36.

Stevenson, Paul Huston. "Notes on the Human Geography of the ChineseTibetan Borderland." Geographic Review 22, no. 4 (1932): 599-616.

Stoddard, Heather. "Tibetan Publications and National Identity." In Resistance and Reform in Tibet, edited by Robert Barnett and Shirin Akiner, 121-156. Bloomington and Indianapolis: Indiana University Press, 1994.

Sun, Shuyun. The Long March: The True History of Communist China's Founding Myth. New York: Doubleday 2006.

Sutton, Donald S. "Ethnicity and the Miao Frontier in the Eighteenth Century." In Empire at the Margins: Culture, Ethnicity, and Frontier in Early Modern China, edited by Pamela Kyle Crossley, Helen F. Siu and Donald S. Sutton, 190-228. Berkeley: University of California Press, 2006.

Tao Baolian 陶保廉. Xinmao shi xingji 辛印侍行记. Lanzhou: Gansu renmin chubanshe, 2000 [1897].

Teichman, Eric. Travels of a Consular Officer in Eastern Tibet; together with a History of the Relations between China, Tibet and India. London: Cambridge University Press, 1922.

Thompson, Roger R. China's Local Councils in the Age of Constitutional Reform, 1898-1911. Cambridge, Mass.: Council on East Asian Studies, Harvard University, 1995. 
Thornton, Patricia M. Disciplining the State: Virtue, Violence, and StateMaking in Modern China. Cambridge, MA: Harvard University Asia Center, 2007.

Tighe, Justin. Constructing Suiyuan: The Politics of Northwestern Territory and Development in Early Twentieth-Century China Leiden: Brill, 2005.

Took, Jennifer. A Native Chieftaincy in Southwest China: Franchising a Tai Chieftaincy under the Tusi System of Late Imperial China. Leiden: Brill, 2005.

Tsin, Michael. Nation, Governance and Modernity in China. Stanford: Stanford University Press, 1999.

Tu Zhongshan 涂仲善. "Tiaozheng Kang qu di quan wenti zhi guan jian 調 整康區地權問題之管見,." Xikang jingji jikan 西康經濟季刊 1, no. 8 (1944): 63-74.

Tuttle, Gray. Tibetan Buddhists in the Making of Modern China. New York: Columbia University Press, 2004.

U, Eddy. Disorganizing China: Counter Bureaucracy and the Decline of Socialism. Stanford: Stanford University Press, 2007.

van de Ven, Hans J. War and Nationalism in China, 1925-1945. London: Routledge, 2003.

Vermeer, Eduard B. "The Mountain Frontier in Late Imperial China: Economic and Social Developments in the Bashan." T'oung Pao 77, no. 5 (1991): 300-29.

Waley-Cohen, Joanna. "China and Western Technology in the Eighteenth Century." American Historical Review 98, no. 5 (1993): 1525-44.

Wang Chuan 王川. "Jindai minzu guanxi shi shang de Xikang jian sheng ji qi lishi yiyi 近代民族关系史上的西康建省及其历史意义." Xizang daxue xuebao 西藏大学学报 23, no. 1 (2008): 36-46.

. "Minguo hou qi "Xikang sheng nongye gaijin suo" de sheli shimo ji qi lishi yiyi 民国后期 “西康省农业改进所” 的设立始末及其历史 意义." Xizang daxue xuebao 西藏大学学报 20, no. 1 (2005): 60-70.

. "Minguo zhong-hou qi de zhengzhi yu zongjiao: Liu Wenhui yu Xikang diqu zangquan fojiao jie 民国中后期的政治与宗教：刘文 辉与西康地区藏传佛教界." In Yijiusanling niandai de Zhongguo 一 九三 0 年代的中国, edited by Zhongguo shehui kexue yuan jindaishi yanjiusuo minguo yanjiushi 中国社会科学院近代史研究所民国研 究室 and Sichuan shifan daxue lishi wenhua xueyuan 四川师范大学 历史文化学院. Beijing: Shehui kexue wenxian chubanshe, 2006. 
_. "Qing mo, Minguo shiqi Xikang diqu de nongye gaijin ji qi shiji chengxiao 清末、民国时期西康地区的农业改进及其实际成效." Minguo Dang'an 民国档案, no. 4 (2004): 54-59.

Wang De'an 王德安. "Jiefang qian Xikang jianshe ting ji jingji jianshe gaikuang 解放前西康建设厅及经济建设概况." In Ya'an wenshi ziliao xuanji: di ba ji 雅安文史资料选辑: 第八辑, edited by Zhongguo renmin zhengzhi xieshang huiyi Sichuan sheng Ya'an shi weiyuanhui 中国人民政治协商会议四川省雅安市委员会. Ya'an: Zhongguo renmin zhengzhi xieshang huiyi Sichuan sheng Ya'an shi weiyuanhui, 1994.

Wang, Di. The Teahouse: Small Business, Everyday Culture, and Public Politics in Chengdu, 1900-1950. Stanford: Stanford University Press, 2008.

Wang Haibing 王海兵. "1930 niandai de Kang, Qing, Zang zhanzheng -bianzheng, quanli he difang de shijiao 1930 年代的康、青、藏战争 一边政、权利和地方的视角." Anhui shixue 安徽史学, no. 6 (2007): 79-84.

Wang Hui 汪晖. Xiandai Zhongguo sixiang de xingqi, shang juan, di er bu: diguo yu guojia 现代中国思想的兴起, 上卷, 第二部: 帝国与国 家. Beijing: San lian shu dian, 2008.

Wang Qiaohong 汪巧红. "Lun wan Qing shiqi wo guo nongye shiyan yu tuiguang 论晚清时期我国农业实验与推广." Anhui nongye kexue 安徽农业科学 36, no. 22 (2008): 9808-10.

Wang Xiuyu. "China's Last Imperial Frontier: Statecraft and Locality in Qing Kham Tibet, 1890-1911." PhD, Carnegie Mellon University, 2006.

Wang, Ye-chien. Land Taxation in Imperial China, 1750-1911. Cambridge, Mass.: Harvard University Press, 1973.

Wang Zhengguan 汪正琯. "Yanyuan jixing 鹽源紀行." Kangdao yuekan 康 導月刊 5, no. 6 (1943): 61-71.

Wang Zhuo 王卓. "Daofu wula neimu jiqi zhengli yijian 道孚烏拉內幕及 其整理意見." Kangdao yuekan 康導月刊 2, no. 5 (1940): 147-55.

Weng Zhizang 翁之藏. Xikang shi kuang 西康實況. Shanghai: Min zhi shu ju, 1930.

Wilkinson, Endymion Porter. Chinese History: a Manual. Cambridge, Mass.: Harvard University Asia Center, 2000. 
Wilson, Ernest Henry. A Naturalist in Western China with Vasculum, Camera, and Gun: being some Account of Eleven Years' Travel, Exploration, and Observation in the more Remote Parts of the Flowery Kingdom. London: Methuen \& Co. Ltd., 1913.

Winnington, Alan. The Slaves of the Cool Mountains. London: Serif, 2008 [1959].

Wright, Tim. "Distant Thunder: The Regional Economies of Southwest China and the Impact of the Great Depression." Modern Asian Studies 34, no. 3 (2000): 697-738.

Wu Guangyao 吳光耀. "Xizang gailiu ben wei ji 西藏改流本未紀." In

Kangqu Zangzu shehui zhenxi ziliao jiyao (shang) 康区藏族社会珍 稀资料辑要 (上), edited by Zhao Xinyu 赵心愚, Qin Heping 秦和 平 and Wang Chuan 王川. Chengdu: Bashu shushe, 2006.

Wu Liucun 伍柳邨. "Yimin jiancun chuyi -- wei shixian sanhua zhengce er jianyi de yi zhong zhidu 移民建村媰議--為實現三化政策而建議的 一種制度." Bianzheng yuekan 邊政月刊 1, no. 4-8 合刊 (1944): 4755.

Wu Luzhong 吳魯仲. "'Yi wu wenti" lungang『夷務問題』論綱." In Xikang sheng jianshe xie jin hui hui wu nianbao: di san ci 西康省建 設協進會會務年報：第三次. Xichang: Xichang Ning yuan yinshua gongsi, 1948.

Wu Migeng 吳醖賡. "Jiejue Xikang Kang Ning liang shu diquan wenti zhi tujing 解決西康康密兩屬地權問題之途徑." Xikang jingji jikan 西 康經濟季刊, no. 5-6(合刊) (194?): 38-43.

Wu Shaohong, and Yang Qinye. "Land-Use and Agricultural Development." In Mountain Geoecology and Sustainable Development of the Tibetan Plateau, edited by Zheng Du, Zhang Qingsong and Wu Shaohong, 181-202. Dordrecht: Kluwer Academic Publishers, 2000.

Wu Tingyu 乌廷玉. "Qing chao tun tian 清朝屯田." Shixue jikan 史学集刊 no. 4 (1996): 30-36.

Wu Wenhui 吴文暉, and Zhu Jianhua 朱鑒華. "Xikang tudi wenti 西康土地 問題." Bianzheng gonglun 邊政公論 3, no. 6 (1944): 3-25.

Wu Yanqin 吴彦勤. Qing mo min guo shiqi Chuan Zang guanxi yanjiu 清末 民国时期川藏关系研究. Kunming: Yunnan renmin chubanshe, 2006.

Xiao Bo 肖波, and Ma Xuanwei 马宣伟. Sichuan junfa hunzhan 四川军阀 混战 1917-1926. Chengdu: Sichuan sheng shehui kexue yuan, 1986. 
Sichuan junfa hunzhan 四川军阀混战, 1927-1934. Chengdu:

Sichuan sheng shehui kexue yuan, 1984.

Xikang sheng caizheng ting 西康省財政廳. Jian sheng hou zhi Xikang caizheng 建省後之西康財政. Kangding: Xikang sheng caizheng ting, 1945.

Xin kou 信口 ['Random Thoughts']. "Wo shuo wo de 我說我的." Daliangshan 大涼山 1, no. 1 (1946): 22-23.

Xu Ming 徐铭, ed. Qing shi lu Yizu shi liao jiyao 清实录彝族史料辑要. Chengdu: Sichuan minzu yanjiu suo, 1983.

Xu Wenchao 许文超. "Zhanhua shangzhanqu diaocha ji 瞻化上瞻区调查记 ." Kangdao yuekan 康導月刊 1, no. 4 (1939): 59-73.

Xu Xiaohui 徐孝恢. "Ningshu ge xian nongye gai guan 甯屬各縣農業概觀 ." Kangdao yuekan 康導月刊 2, no. 12 (1940): 37-40.

Yang Gengguang 楊耿光. "Sichuan Le-Ping kenwu gongshe nian yu nian lai zhi jingguo 四川樂屏墾務公社廿餘年來之經過." Chuanbian jikan 川邊季刊 2, no. 2 (1936): 1-32.

Yang Jianwu 杨健吾. "Minguo shiqi kangqu de jinrong caizheng 民国时期 康区的金融财政." Xizang yanjiu 西藏研究, no. 3 (2006): 102-06.

Yang Lei 羊硈. "Daofu xiao zhi 道孚小志." Chuanbian jikan 川邊季刊 2, no. 1 (1936): 41-100.

Yang Minghong 样明洪. "Lun Qingdai Liangshan Yi qu de tusi zhidu yu gaituguiliu 论清代凉山彝区的土司制度与改土归流." Minzu yanjiu 民族研究, no. 2 (1997): 88-95.

Yang Zhonghua 楊仲華. Xikang ji yao 西康紀要. Shanghai: Shang wu yin shu guan, 1937.

Yi Bin 易斌. "Shilun min chu Sichuan difang zhuyi de sheng ji guanxi 试论 民初四川地方主义的省际关系." Chongqing shifan daxue xuebao 重庆师范大学学报, no. 2 (2008): 85-90.

Yin Ziwen 尹子文. "Luhuo gaikuang 炉霍概况." Kangdao yuekan 康導月 刊 2, no. 4 (1945): 35-47.

Yu Jian 于坚. "Danba: Hengduan shan zhong de lishi huohuashi 丹巴：横 断山中的历史活化石." Zhongguo guojia dili 中国国家地理, Dec. 2006, 136-49. 
Yuan Dahua 袁大化, and Wang Shuwo 王樹枂, eds. Xinjiang tuzhi 新疆圖 志. Taibei: Wenhai chubanshe, 1965 [1910].

Zelin, Madeleine. The Merchants of Zigong: Industrial Entrepreneureship in Early Modern China. New York: Columbia University Press, 2005.

Zeng Chongbi. "Cause Analysis of Meager Salaries of Sichuan Primary School Teachers in the 1930s." Frontiers of History in China 1, no. 4 (2006): 611-28.

Zeng Zhaolun 曾昭掄. Da Liang Shan Yi qu kao cha ji 大涼山夷區考察記. Shanghai: Qiu zhen she, 1947.

"Zhan shi Kangding shi wu jia dongtai 戰時康定物價動態." Xikang jingji jikan 西康經濟季刊 1, no. 5-6 合刊 (1943): 48-55.

Zhang Jian 张践. "Ban yuan fan Zang yu "Ganzi shibian" 斑辕返藏与 “甘 孜事变”." Qinghai minzu yanjiu 青海民族研究 18, no. 4 (2007): 117-121.

Zhang Ming 张鸣, and Sun Mingjing 孙明经. 1939 nian: zoujin Xikang 1939 年: 走进西康. Jinan: Shandong huabao chubanshe, 2003.

Zhang Qun 張辡, ed. Ningshu diaocha baogao huibian 寧屬調查報告彙編: Beijing daxue library, 1939.

Zhang Weijiong 张为昫. "Xikang jian sheng ji Liu Wenhui de tongzhi 西康 建省及刘文辉的统治." In Sichuan wenshi ziliao xuanji, di shiliu ji 四川文史资料选辑，第十六辑. Chengdu: Zhongguo renmin zhengzhi xieshang huiyi Sichuan shengweiyuanhui 中国人民政治协 商会议四川省委员会, Sichuan sheng sheng zhi bianji weiyuanhui 四川省省志编辑委员会, 1965.

Zhang Xiaoli 张晓丽. "Lun Zhang Zhidong de nongye jindaihua sixiang yu shijian 论张之洞的农业近代化思想与实践." Anhui nongye daxue xuebao (shehui kexue ban) 安徽农业大学学报（社会科学版）12, no. 4 (2003): 90-93.

Zhang, Xin. Social Transformation in Modern China: The State and Local Elites in Henan, 1900-1937. Cambridge: Cambridge University Press, 2000.

Zhang Xiuhua 张秀华. "Qing mo fang ken Meng di de shizhi ji qi dui Menggu jingji shehui fazhan de yingxiang 清末放垦蒙地的实质及 其对蒙古经济社会发展的影响." Jilin daxue shehui kexue xuebao 吉林大学社会科学学报 47, no. 3 (2007): 81-86.

Zhang Yongle. "The Future of the Past: On Wang Hui's Rise of Modern Chinese Thought." New Left Review, no. 62 (2010). 
Zhang Zhen'guo 張鎮國. "Feichu Kang qu wula zhidu jianyi shu 廢除康區 烏拉制度建議書." Kangdao yuekan 康導月刊 2, no. 5 (1940): 12846.

Zhang Zhendong 张振东, and Liang Junyan 梁俊艳. "Shilun Qing zhengfu shoufu Xinjiang 试论清政府收复新疆." Wulumuqi zhiye daxue xuebao 乌鲁木齐职业大学学报 15, no. 3 (2006): 26-28.

Zhang Zhiyuan 张志遠. "Xikang keyi kenzhi ma 西康可以墾殖嗎？." Jianshe zhouxun 建設周迅 6, no. 18-19 (1938): 58-62.

Zhang Zihui 张子惠. "Lihua chaiyao zhi jin xi ji qi tedian 理化差徭之今昔 及其特點." Kangdao yuekan 康導月刊 2, no. 5 (1940): 170-72.

Zhao Erfeng 赵尔丰, and Wu Fengpei 吴丰培. Zhao Erfeng Chuan bian zou $d u$ 赵尔丰川边奏牍. Chengdu: Sichuan minzu chubanshe, 1984.

Zhao Xinyu 赵心愚, and Qin Heping 秦和平, eds. Kangqu Zangzu shehui lishi diaocha ziliao jiyao 康区藏族社会历史调查资料辑要. Chengdu: Sichuan minzu chubanshe, 2004.

Zhao Yuntian 赵云田. "Qing mo Chuan bian gaige xintan 清末川边改革新 探." Zhongguo Zangxue 中国藏学, no. 3 (2002): 38-49.

Zheng Lijian 鄭勵儉. "Chuanbian xin di zhi 川邊新地志 [1946]." In Zhongguo Xizang ji Gan Qing Chuan Dian Zang qu fang zhi huibian 中國西藏及甘青川滇藏區方志彙編, Vol 44, edited by Zhang Yuxin 张羽新. Beijing: Xueyuan chubanshe, 2003.

Zheng Shaocheng 鄭少成, and Yang Zhaoji 楊肇基. "Xichang xian zhi 西 昌縣志 [1941]." In Zhongguo Xizang ji Gan Qing Chuan Dian Zang qu fang zhi huibian 中國西藏及甘青川滇藏區方志匯編, Vol 40, edited by Zhang Yuxin 张羽新. Beijing: Xueyuan chubanshe, 2003.

Zheng Xuan 鄭玄, and Kong Yingda 孔穎達, eds. Li ji zheng yi 禮記正義. Shanghai: Shanghai guji chubanshe, 1990.

Zhong $\mathrm{Mu}$ 钟穆. "Minguo shiqi de Zangyang zhuzao 民国时期的藏洋铸造 ." In Ganzi Zhou wenshi ziliao, no. 14 甘孜州文史资料，第十四辑, edited by Zhongguo renmin zhengzhi xieshang huiyi Ganzi Zangzu zizhizhou weiyuanhui 中国人民政治协商会议甘孜藏族自治州委 员会. Kangding: Kangding xian yinshua chang, 1996.

Zhongguo shaoshu minzu shehui lishi diaocha ziliao congkan' xiuding bianji weiyuanhui 《中国少数民族社会历史调查资料丛刊》修订编辑委 员会, ed. Sichuan sheng Liangshan Yizu shehui lishi diaocha (zonghe baogao) 四川省凉山彝族社会历史调查（综合报告）. Beijing: Minzu chubanshe, 2009. 
Zhongguo Zangxue yanjiu zhongxin 中国藏学研究中心, and Zhongguo di er lishi dang'an guan 中国第二历史档案馆, eds. Minguo shiqi Xizang ji Zangqu jingji kaifa jianshe dang'an xuanbian 民国时期西 藏及藏区经济开发建设档案选编. Beijing: Zhongguo Zangxue chubanshe, 2005.

Zhongguo zhongyang dianshitai 中国中央电视台. "Guo shan che: Cheng Kun tielu, Zhongguo tielu xiujian de qiji 国山车: 成昆铁路, 中国 铁路修建的奇迹." China: Zhongguo guoji dianshi zonggongsi, 2007.

Zhou Maoqi 周茂歧. "Cong tudi wenti shuo dao "hong zhao" zhengli 從土 地問題說到『紅照』整理." Bianzheng yuekan 邊政月刊 1, no. 4-6 (合刊) (1944): 52-57.

Zhou Taixuan 周太玄. "Xikang shangye gaikuang 西康商业概况 [1947]." In Jindai Kang qu dang'an ziliao xuanbian 近代康区档案资料选编, edited by Sichuan sheng dang'an guan 四川省档案馆 and Sichuan minzu yanjiu suo 四川民族研究所. Chengdu: Sichuan daxue chubanshe, 1990.

Zhou Yongming. Anti-Drug Crusades in Twentieth Century China:

Nationalism, History, and State Building. Lanham: Rowman and Littlefield Publishers, 1999.

Zhu Zengyun 朱增釷. "Chuanbian zhengxie 川邊政屑 [1914]." In Kangqu Zangzu shehui zhenxi ziliao jiyao (shang) 康区藏族社会珍稀资料辑 要 (上), edited by Zhao Xinyu 赵心愚, Qin Heping 秦和平 and Wang Chuan 王川. Chengdu: Bashu shushe, 2006.

Zou Lihong 邹礼洪. "Qing mo Chuanbian tun ken yu mu zheng di wenti tanxi 清末川边屯垦与牧争地问题探析." Xihua daxue xuebao (zhexue shehui kewen ban) 西华大学学报（哲学社会科学版） 3, no. 4 (2005): 28-31. 